
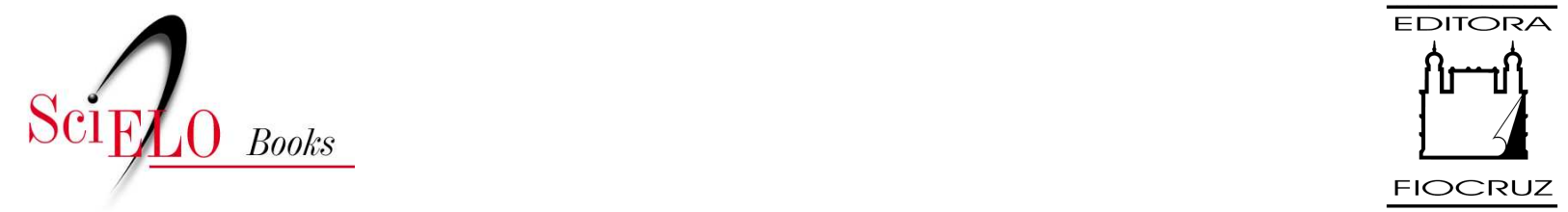

\title{
Principais mosquitos de importância sanitária no Brasil
}

\author{
Rotraut A. G. B. Consoli \\ Ricardo Lourenço de Oliveira
}

\section{SciELO Books / SciELO Livros / SciELO Libros}

CONSOLI, RAGB., and OLIVEIRA, RL. Principais mosquitos de importância sanitária no Brasil [online]. Rio de Janeiro: Editora FIOCRUZ, 1994. 228 p. ISBN 85-85676-03-5. Available from SciELO Books <http://books.scielo.org $>$.

\section{(c) $\underset{\mathrm{BY}}{(\mathrm{NC}}$ (2)}

All the contents of this chapter, except where otherwise noted, is licensed under a Creative Commons Attribution-Non Commercial-ShareAlike 3.0 Unported.

Todo o conteúdo deste capítulo, exceto quando houver ressalva, é publicado sob a licença Creative Commons Atribuição - Uso Não Comercial - Partilha nos Mesmos Termos 3.0 Não adaptada.

Todo el contenido de este capítulo, excepto donde se indique lo contrario, está bajo licencia de la licencia Creative Commons Reconocimento-NoComercial-CompartirIgual 3.0 Unported. 


\section{Principais Mosquitos}

\section{DE IMPORTANCIA}

SANITARIA No BRASIL

Principais Mosquitos de Importância Sanitária no Brasil possui informações concisas e atualizadas sobre os mosquitos vetores de doenças no Brasil. Aqui são fornecidos dados sobre a morfologia e a biologia das fases evolutivas de adulto, ovo, larva e pupa, sendo abordados aspectos referentes à sua nutrição, reprodução, comportamento e ecologia. Para a identificação de adultos e larvas são oferecidas chaves ilustradas abrangendo os Anofelinos e principais Culicíneos já encontrados no país. São apresentados textos específicos contendo informações sobre as principais espécies dos gêneros Anopheles, Aedes, Psorophora, Haemagogus e Culex, dentre outros. Com referência às medidas de controle, são abordados os métodos químicos, a questão da resistência aos inseticidas, bem como as perspectivas dos métodos 


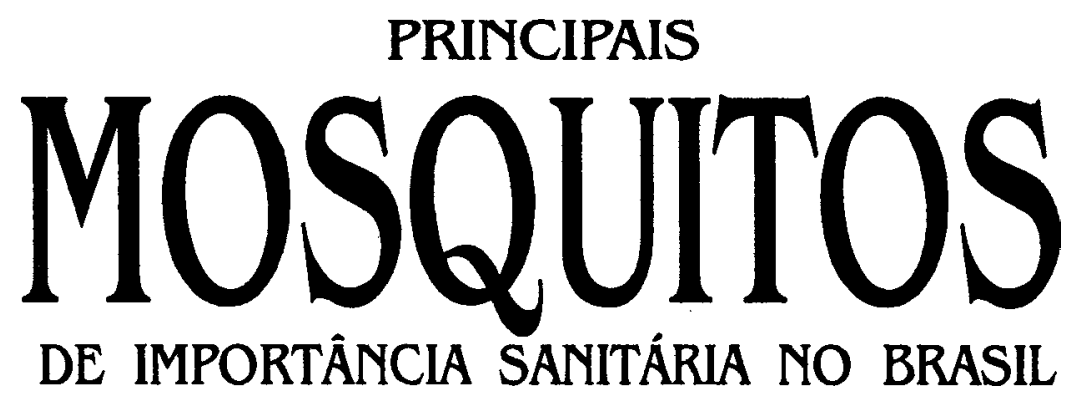




\section{FUNDAÇÃO OSWALDO CRUZ}

Presidente

Eloi de Souza Garcia

Vice-Presidente de Ambiente, Comunicação e Informação Maria Cecília de Souza Minayo

\section{EDITORA FIOCRUZ}

Coordenadora

Maria Cecília de Souza Minayo

Conselho Editorial

Carlos E. A. Coimbra Jr.

Carolina M. Bori

Charles Pessanha

Hooman Momen

Jaime L. Benchimol

José da Rocha Carvalheiro

Luiz Fernando Ferreira

Miriam Struchiner

Paulo Amarante

Paulo Gadelha

Paulo Marchiori Buss

Vanize Macêdo

Zigman Brenner

Coordenador Executivo

João Carlos Canossa P. Mendes 


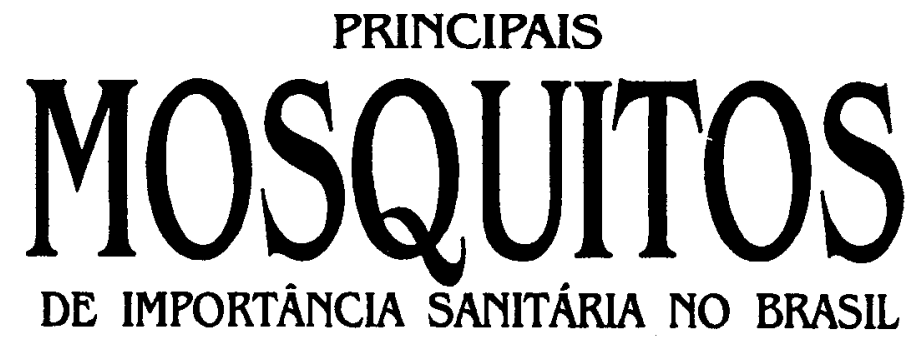

1 Reimpressão

\section{Rotraut A. G. B. Consoli}

Mestre em Parasitologia, Doutor em Ciências, Chefe do Laboratório de Entomologia do Centro de Pesquisas René Rachou, da Fundação Oswaldo Cruz, Ministério da Saúde, Belo Horizonte, Minas Gerais; Orientadora nos Cursos de Mestrado e Doutorado do Departamento de Parasitologia do Instituto de Ciências Biológicas da Universidade Federal de Minas Gerais, Belo Horizonte.

\section{Ricardo Lourenço de Oliveira}

Mestre em Biologia Parasitária, Doutor em Ciências, Pesquisador Adjunto, Chefe do Laboratório de Transmissores de Hematozoarios do Instituto Oswaldo Cruz, Fundação Oswaldo Cruz, Rio de Janeiro; Orientador no Curso de Pós-Graduação em Biologia Parasitária do mesmo Instituto.

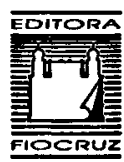


Copyright $(1994$ by Rotraut A. G. B. Consoli e Ricardo Lourenço de Oliveira Todos os direitos desta edição reservados à

FUNDAÇĀO OSWALDO CRUZ/EDITORA

ISBN $85-85676-03-5$

I. Edição: 1994

$1^{*}$ Reimpressão: 1998

Capa: Felipe Ferreira

Foto da Capa: Leonard Mustermann

Programação Visual e Editoração Eletrônica: Heloísa Diniz

Revisão: Marcionílio Cavalcanti de Paiva

Supervisão Técnica: Walter Duarte

SERVIÇO DE MULTIMEIOS/CICT/FIOCRUZ

Catalogação-na-fonte

Centro de Informação Científica e Tecnológica

Biblioteca Lincoln de Freitas Filho

C755 Consoli, Rotraut A. G. B.

Principais mosquitos de importância sanitária no Brasil / Routraut A. G. B.

Consoli, Ricardo Lourenço de Oliveira. - Rio de Janeiro: Fiocruz, 1994.

$228 \mathrm{p}$.

1. Mosquitos - anatomia 2. Mosquitos - classificação 3. Mosquitos - metabolismo 4. Mosquitos - crescimento e desenvolvimento 5. Controle de mosquitos - métodos.

I. Oliveira, Ricardo Lourenço de. II. Título.

CDD. -20 . ed. -595.771

1998

EDITORA FIOCRUZ

Rua Leopoldo Bulhões, 1480, Térreo - Manguinhos

21041-210 - Rio de Janeiro - RJ

Tel.: (021) 5903789 ramal 2009

Fax: (021) 2808194 
Ao nosso Mestre

Prof. Leônidas de Mello Deane

com respeito, admiração

e afeto 


\section{Agradecimentos}

trabalho.

Os autores são gratos a todos que contribuíram para a realização deste

Ao Prof. Leônidas de Mello Deane, do Departamento de Entomologia do Instituto Oswaldo Cruz, Fundação Oswaldo Cruz, Rio de Janeiro, pela revisão do manuscrito e pelas sugestões.

Ao Dr. Naftale Katz, Diretor do Centro de Pesquisas René Rachou, da Fundação Oswaldo Cruz, pelo estímulo à elaboração do mesmo.

A Leonard Mustermann, Leon Phillips Lounibos, Teresa Fernandes da Silva, Maria Goreti Rosa-Freitas e Ayami Tanaka pela concessão e/ou elaboração de algumas ilustrações.

A Felipe Ferreira e Itamar Bastos Crispim pelas sugestões e colaboração da programação visual da capa, e a Heloisa Diniz pela programação visual do texto.

Ao Serviço de Multimeios da Fundação Oswaldo Cruz, Rio de Janeiro, pelo apoio técnico na editoração.

A Marli Maria Lima e Ana Cristina Brito dos Santos, pela leitura crítica do manuscrito.

A Elzira Pereira da Silva, por parte do serviço de datilografia. 


\section{Apresentação}

Por mais de um motivo estou contente ao apresentar este manual.

Primeiro, por serem seus autores os competentes colegas Rotraut e Ricardo, meus diletos ex-alunos, respectivamente na Universidade Federal de Minas Gerais e no Instituto Oswaldo Cruz. O convívio com eles me fizera cedo prever que viriam a ser os cientistas produtivos e respeitados de hoje.

Segundo, pelo valor do proprio manual. Nele, os interessados em mosquitos brasileiros e na sua importância sanitária encontrarão informações atualizadas, começando com a morfologia e o comportamento do grupo em geral, seguidos da sistemática ajudada por chaves de identificação ilustradas e um relato da distribuição geográfica e da biologia das espécies mais importantes, com ênfase na transmissão de doenças. Após uma descrição dos métodos de controle químico e biológico dos mosquitos, segue-se uma detalhada exposição das principais técnicas de trabalho relacionadas com esses insetos, terminando com uma série de referências bibliográficas a que se poderá recorrer para um conhecimento mais detalhado de cada item tratado.

A obra, que certamente será muito útil, reflete a já grande experiência pessoal dos jovens autores em trabalhos de laboratório e de campo neste setor importante da entomologia médica em nosso país. 


\section{Sumário}

CONSIDERAÇÕES GERAIS $\ldots \ldots \ldots \ldots \ldots \ldots \ldots$

1 -MORFOLOGIA EXTERNA . . . . . . . . . . . . . . . . . 19

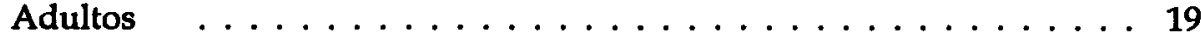

Cabeça . . . . . . . . . . . . . . . . . 19

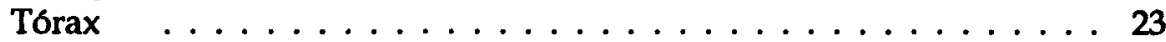

Abdome . . . . . . . . . . . . . . . . 27

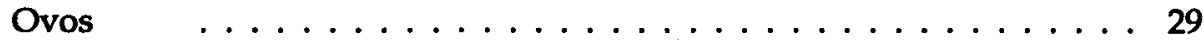

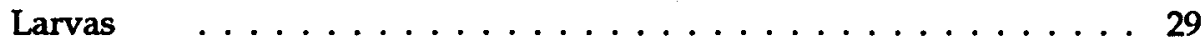

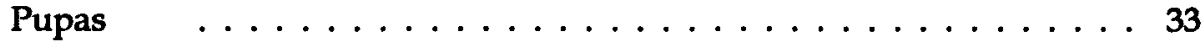

\section{2 - BIOLOGIA E MORFOLOGIA INTERNA}

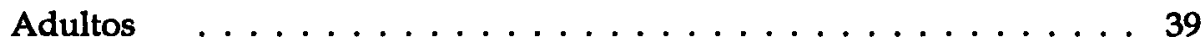

Alimentação e Nutrição . . . . . . . . . . . . . . . . . . . . 39

Aparelho digestivo . . . . . . . . . . . . . . . 39

Alimentação com carboidratos . . . . . . . . . . . 40

Alimentação sanguínea . . . . . . . . . . . . . . . . . . 41

Digestão sanguínea . . . . . . . . . . . . . . . . . 41

Necessidades nutricionais . . . . . . . . . . . . 41

Excreção . . . . . . . . . . . . . . . . 42

Reprodução . . . . . . . . . . . . . . . . 42

Acasalamento .................. . . 42

Fecundação . . . . . . . . . . . . . . 42

Concordância e discordância gonotrófica . . . . . . . . . 43

Aparelho reprodutor masculino . . . . . . . . . . 44

Aparelho reprodutor feminino $\ldots \ldots \ldots \ldots \ldots \ldots \ldots$

Ovariolo . . . . . . . . . . . . . . . . 45

Desenvolvimento do folículo ovariano . . . . . . . . 45

Idade cronológica e idade fisiológica . . . . . . . . . . . . . 46

Ovulação, fertilização e oviposição . . . . . . . . . . . . . 46

Comportamento de oviposição . . . . . . . . . . . . . . 46

Órgãos dos sentidos . . . . . . . . . . . . . . . . 47

Visão . . . . . . . . . . . . . . . . . . 47

Audição . . . . . . . . . . . . . . . . 47 
Quimiorreceptores . . . . . . . . . . . . . . 47

Outros órgãos dos sentidos . . . . . . . . . . . . 47

Longevidade . . . . . . . . . . . . . . 48

Ovos $\ldots \ldots \ldots \ldots \ldots \ldots \ldots \ldots \ldots \ldots \ldots \ldots \ldots$

Desenvolvimento embrionário . . . . . . . . . . . 48

Eclosão e diapausa . . . . . . . . . . . . . . . 48

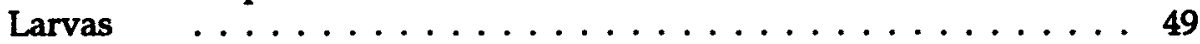

Respiração . . . . . . . . . . . . . . . . . 49

Alimentação e nutrição . . . . . . . . . . . . . . 50

Sistema digestivo. . . . . . . . . . . . . . 50

Necessidades nutricionais $\ldots \ldots \ldots \ldots \ldots \ldots \ldots \ldots$

Reservas nutricionais . . . . . . . . . . . . 52

Excreção e desintoxicação . . . . . . . . . . . . . . 52

Mecanismos de regulação . . . . . . . . . . . . . . 52

Larvas predadoras . . . . . . . . . . . . . . 52

Desenvolvimento larvário . . . . . . . . . . . . . 53

Principais fatores ambientais que interferem no

desenvolvimento larvário . . . . . . . . . . . . 53

Temperatura . . . . . . . . . . . . . . 53

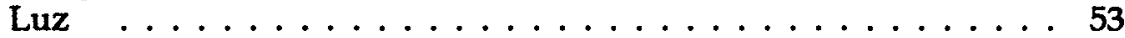

Salinidade ..................... 54

Poluentes orgânicos e inorgânicos . . . . . . . . . 54

Movimento da água . . . . . . . . . . . . 54

Relações com a vegetação não aquática $\ldots \ldots \ldots \ldots \ldots \ldots$

Produtos químicos derivados de plantas . . . . . . . . 55

Relaçōes com animais ... . . . . . . . . . . 55

Criadouros .................... 56

\section{3 - CLASSIFICAÇÃO E PRINCIPAIS ESPECIES DE IMPORTÂNCIA}

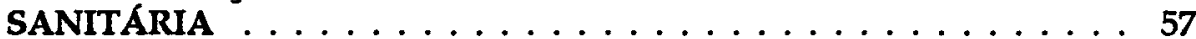

Subfamilia Toxorhynchitinae . . . . . . . . . . . . . . 57

Principais diferenças entre anofelinos e culicíneos . . . . . . . . . . 58

Subfamúliz Anophelinae . . . . . . . . . . . . . . . 59

Gênero Chagasia Cruz, 1906 . . . . . . . . . . . . . . . . . . 59

Gênero Anopheles Meigen, 1818 . . . . . . . . . . . . . . 60

Chave para a identificação dos subgêneros de Anopheles na

fase adulta que ocorrem no Brasil. . . . . . . . . . . . . 60

Chave para a identificação de adultos das espécies de Anopheles que ocorrem no Brasil . . . . . . . . . . . . . . . . 61

Chave para a identificação de larvas das espécies de Anopheles que ocorrem no Brasil . . . . . . . . . . . . . . 70

Subgênero Nyssorhynchus Blanchard, $1902 \ldots \ldots \ldots \ldots$. . . . 79

Anopheles darlingi Root, $1926 \ldots \ldots \ldots$. . . . . . . 80

Anopheles aquasalis Curry, $1932 \ldots \ldots \ldots$. . . . . . . . 82

Anopheles albitarsis Lynch - Arribalzaga, $1878 \ldots \ldots . \ldots . . .83$

Anopheles deaneorum Rosa-Freitas, 1989 . . . . . . . . . . . 84

Anopheles braziliensis Chagas, 1907 . . . . . . . . . . . . . 85 
Anopheles nuneztovari Galbadon, $1940 \ldots \ldots$. . . . . . . 85

Anopheles triannulatus Neiva \& Pinto, $1922 \ldots \ldots$. . . . . . 86

Anopheles oswaldoi Peryassú, $1922 \ldots \ldots$. . . . . . . . 87

Outros Nyssorhynchus . . . . . . . . . . . . . . . 88

Subgênero Kerteszia Theobald, $1905 \ldots \ldots$. . . . . . . . 88

Anopheles cruzii Dyar \& Knab, 1903 . . . . . . . . . . . . . . 89

Anopheles bellator Dyar \& Knab, $1906 \ldots \ldots$. . . . . . . 90

Anopheles homunculus Komp, 1937 . . . . . . . . . . . . . . 91

Subfamília Culicinae . . . . . . . . . . . . . . . . . . . . . . 92

Chave para identificação das tribos e gêneros de Culicinae: adultos . 93

Chave para identificação das tribos e gêneros de Culicinae: larvas . . . 98

Tribo Aedeomyiini . . . . . . . . . . . . . . . . . . . 102

Aedeomyia squamipennis Theobald, $1901 \ldots \ldots$. . . . . . . . 102

Tribo Aedini . . . . . . . . . . . . . . . . . . . . . . 102

Gênero Aedes Meigen, 1818 . . . . . . . . . . . . . . . . . . . 104

Chave para identificação das espécies de Aedes que ocorrem

no Brasil: fêmeas . . . . . . . . . . . . . . . . . . . 105

Chave para identificação das espécies de Aedes que ocorrem no

Brasil larvas . . . . . . . . . . . . . . . . 110

Subgênero Stegomyia Theobald, $1901 \ldots \ldots \ldots \ldots \ldots$

Aedes aegypti Linnaeus, 1762 . . . . . . . . . . . . . . . . 115

Aedes albopictus Skuse, 1894 . . . . . . . . . . . . . 118

Subgênero Ochlerotatus Linch-Arribalzaga, 1894 . . . . . . . . . 119

Aedes scapularis Rondani, 1848 . . . . . . . . . . . . . . 119

Aedes taeniorhynchus Wiedemann,1821 . . . . . . . . . . 121

Outras espécies de Ochlerotatus . . . . . . . . . . . . . . . 121

Gênero Psorophora Robineau-Desvoidy, 1827 . . . . . . . . . . . 122

Chave para a identificação das espécies de Psorophora que

ocorrem no Brasil: fêmeas . . . . . . . . . . . . . . . . . . 123

Subgênero Psorophora Robineau-Desvoidy, 1827 . . . . . . . . . 126

Subgênero Grabhamia Theobald, 1903 . . . . . . . . . . . . 126

Subgênero Janthinosoma Lynch - Arribalzaga, $1891 \ldots \ldots$

Psorophora ferox Von Humboldt, 1819 . . . . . . . . . . . . 127

Gênero Haemagogus Williston, 1876 . . . . . . . . . . . . . . . . 128

Chave para identificaçăo das fêmeas de Haemagogus que ocorrem

no Brasil . . . . . . . . . . . . . . . . . . . . . . . . 129

Subgênero Haemagogus Williston, $1896 \ldots \ldots \ldots \ldots$

Haemagogus janthinomys Dyar, 1921 . . . . . . . . . . . . 131

Haemagogus albomaculatus Theobald, $1903 \ldots \ldots$. . . . . . 132

Haemagogus capricornii Lutz, 1904 . . . . . . . . . . . . . . 133

Haemagogus spegazzinii Brethes, 1912 . . . . . . . . . . . . 133

Subgênero Conopostegus Dyar, 1925 . . . . . . . . . . . . . 133

Haemagogus leucocelaenus Dyar \& Shannon,1924 . . . . . . . 134

Tribo Culicini . . . . . . . . . . . . . . . . . . . . . . 134

Gênero Culex Linnaeus, 1758 . . . . . . . . . . . . . . . . . . . 134

Chave para a identificação dos subgêneros de Culex que ocorrem

no Brasil, na fase adulta . . . . . . . . . . . . . . 135 
Subgênero Culex Linnaeus, 1758 . . . . . . . . . . . . . . . 138

Culex quinquefasciatus Say, $1823 \ldots \ldots$. . . . . . . . . . 139

Culex nigripalpus Theobald, $1901 \ldots \ldots \ldots$. . . . . . . 142

Culex coronator Dyar \& Knab, 1906 . . . . . . . . . . . . 143

Culex saltanensis Dyar, 1928 . . . . . . . . . . . . 143

Culex declarator Dyar \& Knab, 1906 . . . . . . . . . . 144

Subgênero Melanoconion Theobald, 1903 . . . . . . . . . . 144

Gênero Deinocerites Theobald, 1901 . . . . . . . . . . . . . . . . 146

Tribo Mansoniini . . . . . . . . . . . . . . . . . . . . . 146

Gênero Mansonia Blanchard, $1901 \ldots \ldots$. . . . . . . . . 147

Mansonia titillans Walker, 1848 . . . . . . . . . . . . . 148

Gênero Coquillettidia Dyar, 1905 . . . . . . . . . . . . . . . 148

Tribo Orthopodomyiini . . . . . . . . . . . . . . . . . . 149

Gênero Orthopodomyia Theobald, 1904 . . . . . . . . . . . . . . 149

Tribo Uranotaeniini . . . . . . . . . . . . . . . . . . . . . . . . . 149

Gênero Uranotaenia Lynch - Arribalzaga, 1891 . . . . . . . . . . 149

Tribo Sabethini . . . . . . . . . . . . . . . . . . . . . 150

Gênero Sabethes Robineau - Desvoidy, 1827 . . . . . . . . . . 150

Sabethes chloropterus Humboldt, 1819 . . . . . . . . . 151

Outros Sabethini . . . . . . . . . . . . . . . . . 152

4 - CONTROLE QUÍMICO E BIOLÓGICO: PERSPECTIVAS . . . . . . . 155

Controle químico . . . . . . . . . . . . . . . . 155

Resistência a inseticidas . . . . . . . . . . . . . 156

Inseticidas químicos alternativos $\ldots \ldots \ldots \ldots \ldots \ldots \ldots$

Controle biológico . . . . . . . . . . . . . . . . . 157

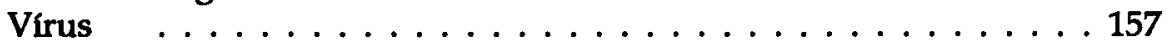

Bactérias . . . . . . . . . . . . . . . . . 157

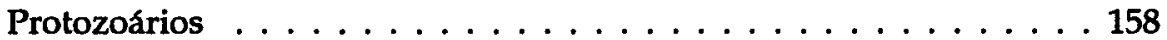

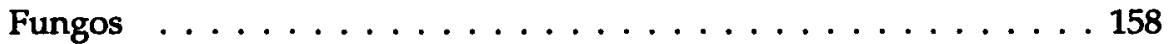

Nematódeos . . . . . . . . . . . . . . . . 158

Invertebrados predadores . . . . . . . . . . . . . . . 159

Peixes . . . . . . . . . . . . . . . . . . . 159

5 -TÉCNICAS . . . . . . . . . . . . . . . 161

Coleta de adultos . . . . . . . . . . . . . . . . . . . . 161

Coleta de larvas . . . . . . . . . . . . . . . . . . . . . 165

Medidas quantitativas de larvas . . . . . . . . . . 166

Por área de superfície . . . . . . . . . . . . . . 166

Por volume de água . . . . . . . . . . . . . . . . 166

Técnicas de transporte . . . . . . . . . . . . . . . 167

Mosquitos mortos . . . . . . . . . . . . . . . . 167

Adultos . . . . . . . . . . . . . . . . . . . 167

Formas imaturas . . . . . . . . . . . . . . 168

Mosquitos vivos . . . . . . . . . . . . . 168

Adultos . . . . . . . . . . . . . . . . . . 168

Formas imaturas . . . . . . . . . . . . . . . 169 
Técnicas de montagem . . . . . . . . . . . . . . . . . . . . . 170

Em alfinetes entomológicos . . . . . . . . . . . . . . . 170

Em lâminas . . . . . . . . . . . . . . . . . . 171

Técnicas de dissecção . . . . . . . . . . . . . . . . . . . . . . 171

Dissecção do sistema digestivo . . . . . . . . . . . . . . . . 172

Dissecção das glândulas salivares e detecção de esporozoítos . . . . . 172

Dissecção de ovários e ovariolos . . . . . . . . . . . . . . 173

Técnicas imunológicas para a detecção de infecção plasmodial em

anofelinos . . . . . . . . . . . . . . . . . . . 174

Radioimunensaio (IRMA) . . . . . . . . . . . . . 175

ELISA $\ldots \ldots \ldots \ldots \ldots \ldots \ldots \ldots \ldots \ldots$

Testes para medir a susceptibilidade de mosquitos a substâncias

inseticidas . . . . . . . . . . . . . . . . . . 179

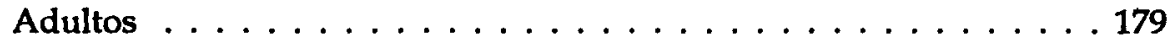

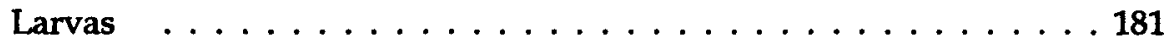

Criação de Culicídeos . . . . . . . . . . . . . . . . . 183

Algumas considerações éticas e medidas de segurança . . . . . . . . 183

O insetário: normas gerais $\ldots \ldots \ldots \ldots \ldots \ldots \ldots \ldots$

Controle de temperatura e umidade . . . . . . . . . . . . 185

Luminosidade ... . . . . . . . . . . . . . . . . . . 185

Manutenção de adultos . . . . . . . . . . . . . . 185

Manutenção dos ovos . . . . . . . . . . . . . . . 187

Mosquitos que desovam na água . . . . . . . . . . . 187

Mosquitos que desovam em superfícies sólidas . . . . . . . . . . 187

Eclosão larvária . . . . . . . . . . . . . . . . . . 188

Manutenção das larvas . . . . . . . . . . . . . 188

Manutenção das pupas . . . . . . . . . . . . . . . . . . . 189

Manejo de colônias acidentalmente contaminadas por

microorganismos e prevenção . . . . . . . . . . . . . . . . 190

Colonização de algumas espécies de mosquitos . . . . . . . . . . . 190

Culex quinquefasciatus Say, $1823 \ldots \ldots$. . . . . . . . . . 190

Aedes fluviatilis Lutz, $1904 \ldots \ldots$. . . . . . . . . . . 191

Aedes aegypti Linnaeus, $1762 \ldots \ldots \ldots$. . . . . . . . . 191

Aedes albopictus Skuse, 1894 . . . . . . . . . . . . . . . . . 192

Anopheles deaneorum Rosa-Freitas, 1989 e outros Nyssorhynchus . . . 194

REFERENCIAS BIBLIOGRAFICAS . . . . . . . . . . . . . . . 197

INDICE REMISSIVO . . . . . . . . . . . . . . . . . . . . 215 


\section{Considerações Gerais}

Os mosquitos são insetos dípteros, pertencentes à Família Culicidae, conhecidos também como pernilongos, muriçocas ou carapanãs. Os adultos são alados, possuem pernas e antenas longas e na grande maioria são hematófagos, enquanto as fases imaturas são aquáticas. Seu ciclo biológico compreende as seguintes fases: ovo, quatro estágios larvais, pupa e adulto.

As irês primeiras espécies de mosquito foram descritas em meados do século XVIII, e alguns aspectos gerais de seu ciclo biológico também foram então conhecidos. A essa altura, e por muitos anos, pensava-se que a única inconveniência desses insetos era o incômodo causado por sua picada. Porém, foi somente nas últimas décadas do século XIX, quando se descobriu que a filariose bancroftiana e a malária são transmitidas pelos mosquitos, que os cientistas passaram ao estudo mais detalhado de sua biologia e sistemática. A partir da descoberta do papel desses insetos na veiculação de arboviroses, como a febre amarela, o dengue e as encefalites, sua história natural recebeu ainda mais a atenção dos pesquisadores de várias partes do mundo, que procuraram conhecer bem sua biologia, a fim de descobrir nela os pontos vulneráveis para mais facilmente combatê-los.

Assim, no final da primeira década de nosso século já se conheciam quase 250 espécies de mosquitos. A base da taxonomia dos Culicidae eram os caracteres morfológicos externos dos adultos, especialmente das fêmeas. A morfologia das larvas passou, realmente, a integrar a sistemática dos mosquitos na década seguinte.

Ainda nos anos vinte, identificaram-se áreas européias onde havia abundância de certo anofelino, mas não se adquiria malária. Essa situação foi denominada "anofelismo sem malária". Tal fato acabou por evidenciar a existência do que se conhece como "complexo de espécies crípticas", ou conjunto de espécies cujos adultos são indistinguíveis ou ligeiramente distintos. Nessa época, lançouse mão do estudo do aspecto dos ovos dos anofelinos e se aprimoraram os estudos morfológicos das fêmeas, dos machos e das fases imaturas, além de se realizarem observações cada vez mais detalhadas sobre a vida de cada espécie ou 
população de mosquito. Havia grande interesse pela culicidiologia naqueles anos.

Porém, o DDT, inseticida eficiente e de efeito residual, descoberto em 1939, passou a ser empregado, com sucesso, no combate aos mosquitos e outros artrópodes de interesse médico. A eficiência desse inseticida levou a um otimismo exagerado; acreditava-se que as doenças transmitidas por insetos, particularmente por mosquitos, seriam erradicadas em poucos anos. Houve grande desinteresse pela culicidiologia, embora temporário, pois logo surgiram espécies resistentes ao DDT. A essa altura, os pesquisadores já se preocupavam com aspectos da fisiologia dos mosquitos e incluíam as abordagens citogenética e a bioquímica nos estudos sobre a sistemática desses insetos.

Em nosso país, as campanhas contra as epidemias de febre amarela silvestre e de malária, transmitida pelo Anopheles gambiae, ocorridas nos anos trinta e quarenta, contribuíram muito para estimular as investigações taxonômicas e ecológicas dos mosquitos brasileiros. As informações sobre a sistemática e a biologia de nossos mosquitos, que se encontravam pulverizadas nas contribuições feitas por diversos autores através dos anos, foram reunidas em espécies de compêndios de culicidiologia durante os anos quarenta a sessenta, incluindo as chaves dicotômicas disponíveis em nossos dias".

Hoje, existem bem mais de 3.000 espécies de mosquitos descritas, embora ainda se desconheça a biologia da grande maioria delas e os melhores meios para combater muitas daquelas sabidamente malfeitoras.

Há duas décadas, pesquisadores vêm empregando técnicas mais sofisticadas, isto é, moleculares, para compreenderem melhor a sistemática, filogenética e a relação de suscetibilidade ou refratariedade dos mosquitos com os patógenos transmissíveis. Pesquisa-se ávidamente o genoma dos mosquitos e se pensa em produzir mosquitos trangênicos, capazes de bloquear o desenvolvimento de patógenos em seu organismo, ficando impossibilitados de levarem as formas infectantes ao homem e animais, tal como faziam seus antepassados ou precursores. Mas enquanto isso não acontece, ou até que se tenha segurança da irreversibilidade e se conheçam os riscos potenciais da manipulação genética, ainda podemos tirar vantagem das experiências acumuladas e informações de que já dispomos sobre os mosquitos e avançar no conhecimento da sua sistemática e biologia.

* Lane \& Cerqueira (1942); Deane, Causey \& Deane (1948), Lane (1953), Forattini (1962;1965a,b) 


\section{MORFOLOGIA EXTERNA}

A nomenclatura dos aspectos morfológicos dos mosquitos é hoje um pouco mais uniforme que há poucas décadas. Usaremos a nomenclatura proposta por Harbach \& Knight (1980) por ser a mais comumente empregada nas publicações recentes.

Da mesma forma que os demais insetos, os mosquitos têm seu corpo segmentado e revestido pelo exoesqueleto ou cutícula, formado principalmente por quitina. Tais segmentos endurecidos e as membranas que os unem englobam uma cavidade chamada hemocele, repleta de hemolinfa, líquido que banha os órgãos em geral. As partes endurecidas de cada segmento são chamadas escleritos, e as membranosas, pleura. Os escleritos dorsais são os tergitos, os ventrais os esternitos e os laterais os pleuritos. Dessa forma, o corpo dos mosquitos é formado por espécies de anéis compostos de tergito unido ao pleurito e esse ao esternito e vice-versa, sendo a ligação desempenhada pelas pleuras ou membranas pleurais.

Os afixos "tergo" e "noto" (respectivamente, "tergu" do latim e "nôtos" do grego) são empregados para caracterizar os escleritos dorsais e esterno (do grego "stérnon") para os ventrais. Deste modo, o pronoto, por exemplo, é a porçăo dorsal do protórax, e assim por diante.

\section{ADULTOS}

O corpo do adultos é nitidamente dividido em cabeça, tórax e abdome. $\mathrm{Na}$ cabeça encontram-se os principais órgãos dos sentidos, como os olhos, as antenas e os palpos. No tórax estão os apêndices especializados na locomoção, isto é, as patas e as asas. $O$ abdome inclui a maior parte dos órgãos internos, dos aparelhos reprodutor, digestivo e excretor.

\section{Cabeça}

Globosa, sendo ocupada na maior parte ântero-lateral pelos olhos (Fig.1a). Esses são convexos, reniformes e compostos, ou seja, consistem de um agregado de elementos ópticos: os omatídeos. As antenas dos mosquitos são do 


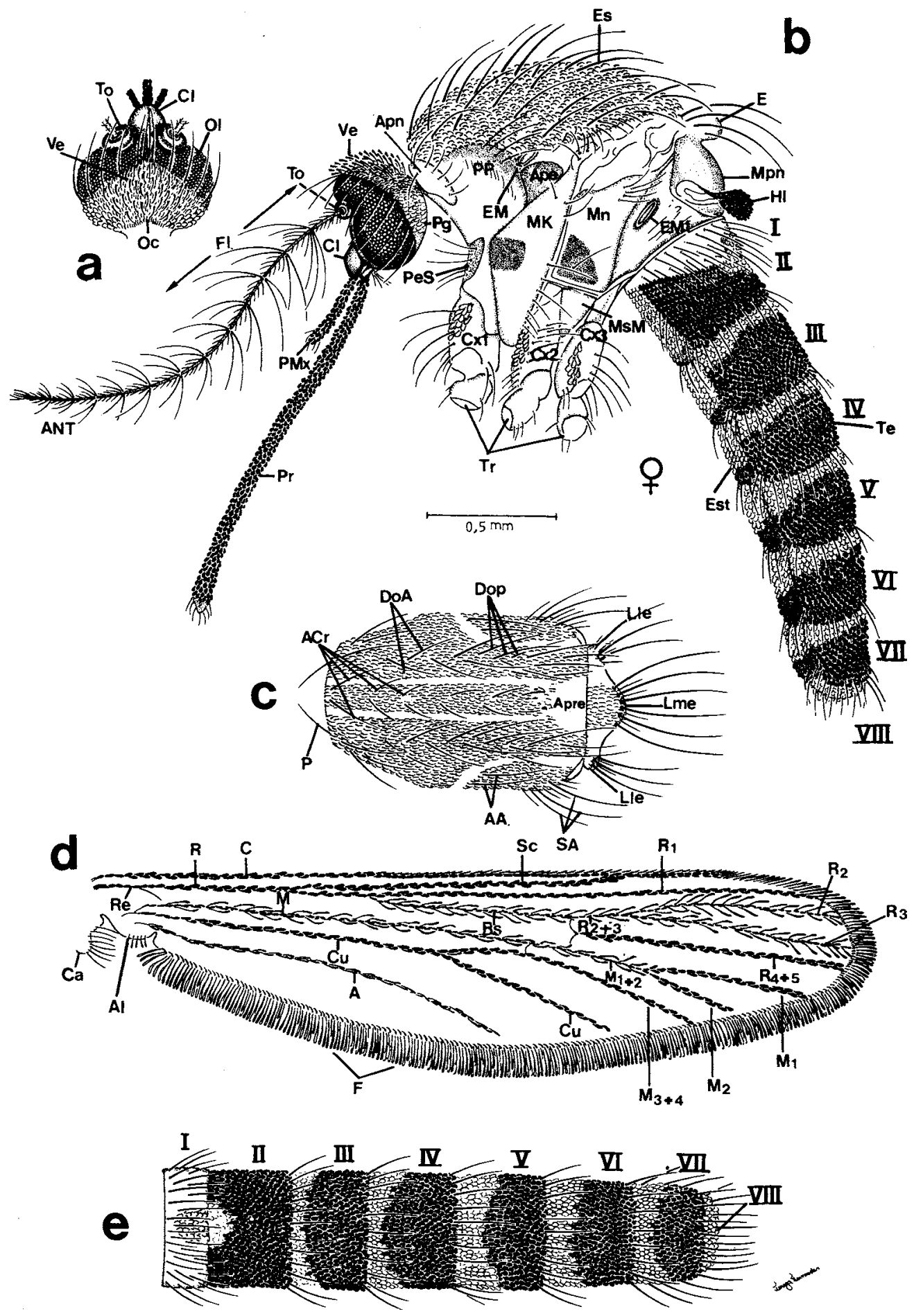


tipo nematócero, isto é, são longas e compostas de 15 ou 16 segmentos, sendo o primeiro deles estreito e em forma de anel - o escapo, o segundo globoso - o toro ou pedicelo, e os demais 13-14, geralmente alongados, são chamados segmentos flagelares. $O$ aspecto da porção flagelar da antena varia de acordo com o sexo do mosquito: nos machos, os pêlos implantados nos segmentos são mais numerosos e longos do que nas fêmeas, além de se encontrarem inseridos, geralmente, na porção subapical naqueles e basal nessas. Dessa maneira as antenas das fêmeas são denominadas pilosas e a dos machos plumosas (Figs. 1 e 2). Porém, tal diferença nem sempre é tão nítida, como por exemplo no caso de alguns elementos da Tribo Sabethini.

Entre os olhos e abaixo das duas antenas acha-se uma estrutura abaulada denominada clípeo e logo abaixo deste se origina o conjunto de órgãos do aparelho bucal, que no caso dos mosquitos é do tipo picador ou pungitivo. Este é constituído por seis estiletes - um par de maxilas e um par de mandíbulas, o hipofaringe e o labro - que se encontram alojados em uma espécie de estojo ou calha alongada, o lábio. Na extremidade do lábio articulam-se duas pequenas estruturas que representam os palpos labiais, denominadas labelas. $O$ labro tem aspecto de uma calha, contribuindo para formar o que chamamos de canal alimentar (por onde passa o sangue puncionado). Ao longo do hipofaringe corre $o$ canal salivar por onde flui a secreção das glândulas salivares. Todo este conjunto de peças bucais é denominado probóscide ou tromba, que por sua vez é ladeada na porção basal pelos palpos maxilares (Figs. 1 e 3). Estes são constituídos de cinco segmentos (o primeiro reduzido e os demais bem evidentes) e têm grande importância na sistemática, além de facilitar na diferenciação dos sexos nos mosquitos: na grande maioria das espécies os palpos maxilares dos machos são iguais no comprimento ou maiores do que o da probóscide. Nas fêmeas (exceto na subfamília Anophelinae) são curtos (Figs. 1-4).

1 Fig. 1: Aspectos da morfologia externa do adulto fêmea. a: cabeça, vista dorsal; b: cabeça, torax e abdome, vista lateral; c: escudo e escutelo, visia dorsal; d: asa, vista lateral; e: abdome, vista dorsal. A: veia anal (ou sexta veia longitudinal); AA: cerdas antealares; ACr: cerdas acrosticais; Al: álula; ANT: antena; Ape: área pós-espiracular; APn: antepronoto; Apre: área pré-escutelar; $\mathrm{C}$ : veia costa; Ca: calíptera (ou calípter superior); $\mathrm{Cl}$ : clipeo; $\mathrm{Cu}$ : veia cúbito; Cx1: coxa anterior; Cx2: coxa média; Cx3: coxa posterior; DoA: cerdas dorso-centrais anteriores; Dop: cerdas dorso-centrais posteriores; E: escutelo; Es: escudo; EM: espiráculo mesotorácico; EMT: espiráculo metatorácico; Est: esternito; F: franja da asa; Fl: flagelo; Hl; halter; LlE: lobo lateral do escutelo; LmE: lobo mediano do escutelo; M: veia média (ou base da quarta veia longitudinal); MK: mesocatepisterno; Mn: mesanepímero; Mpn: mesoposnoto; MsM: mesómeron; M1: veia média 1; $\mathbf{M}_{1+2}$ : veia média $1+2$; $\mathbf{M}_{2}$ : veia média 2; Oc: occipício; Ol: olho; P: cerdas promontoriais; PeS: proepisterno; Pg: pós-gena; PMx: palpo maxilar; PP: pronoto posterior ou f5́s-pronoto; PR: probóscide; $R$ : veia rádio; $\mathbf{R}_{1}$ : veia rádio 1 (ou primeira veia longitudinal); $\mathbf{R}_{2}$ : veia rádio $2 ; \mathbf{R}_{2+3}$ : veia rádio $2+3 ; \mathbf{R}_{3}$ : veia rádio $3 ; \mathbf{R}_{4+5}$ : veia rádio $4+5$ (ou terceira veia longitudinal); Rs: setor radial (ou base da segunda veia longitudinal); SA: cerdas supra-alares; Sc: veia subcosta; Te: tergito; To: toro (ou pedicelo); Tr: trocanter; Ve: vértex (vértice); I a VII: segmentos abdominais. 

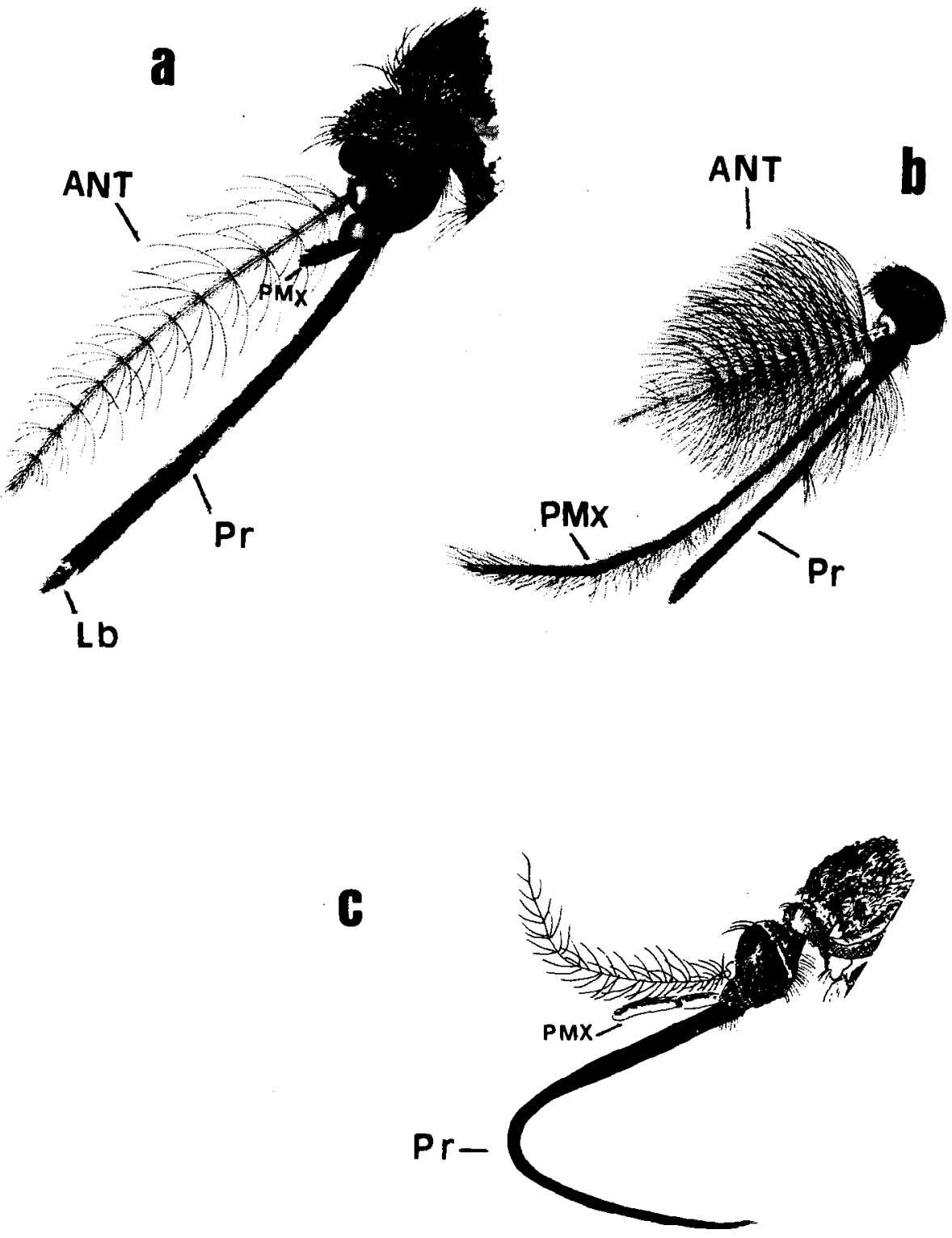

Fig. 2: Aspectos da morfologia externa do adulto - cabeça, vista lateral. a: fêmea de Culicinae; b: macho de Culicinae; c: fêmea de Toxorhynchitinae. ANT: antena; PMx: palpo maxilar; Pr: probóscide; Lb: labela. 


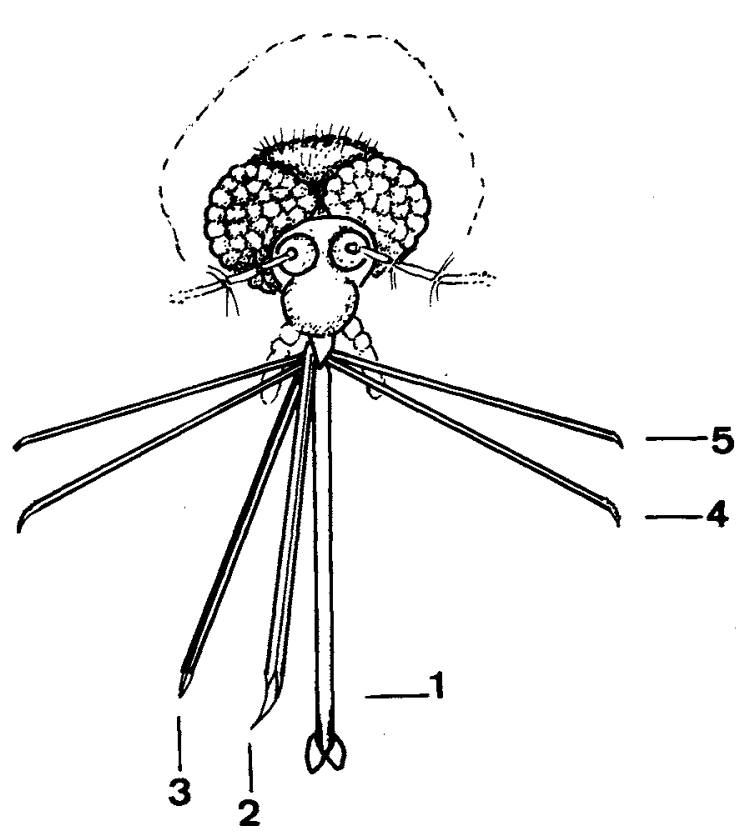

a

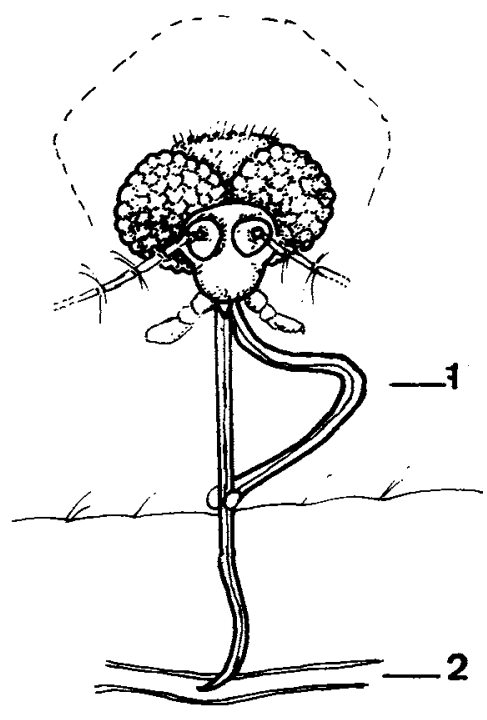

b

FIG. 3: a: Aparelho bucal. Peças bucais picadoras de fêmea. 1: lábio com labela; 2: labro; 3: hipofaringe; 4: maxila; 5: mandíbula. b: Fêmea sugando. 1: lábio; 2: capilar.

\section{Tórax}

Como nos dípteros em geral, o protórax e o metatórax são pouso desenvolvidos. Enquanto isso, o mesotórax ocupa a maior porção deste tagma, pois estão nele as asas realmente funcionais. As asas metatorácicas estão mcdificadas em halteres, que parecem auxiliar na orientação e equilíbrio durante o vôo.

$O$ aspecto geral do tórax dos mosquitos e o nome de suas placas ou porções encontram-se nas Figs. 1 e 5. Daremos no texto apenas algumas particularidades sobre este conjunto.

Observando-se a face dorsal do tórax de um mosquito, vê-se que o pronoto está representado por dois lobos chamados antepronotos, seguidos pelo escudo, no qual está fundido, distalmente, o escutelo. O escudo e o escutelo formam o mesonoto. Após o escutelo, acha-se uma porção abaulada do mesotórax chamada mesoposnoto. Examinando-se a face lateral, nota-se a presença de dois espiráculos (mesotorácico e metatorácico), estruturas que representam a abertura de traquéias para o exterior. As placas que compõem essa face e os grupos de cerdas ou de escamas aí situados recebem denominação particular, conforme as Figs. 1 e 5. Cabe ressaltar que, ao se questionar numa chave dicotômica sobre a presença de uma determinada cerda num espécime em exame, deve-se referir à 

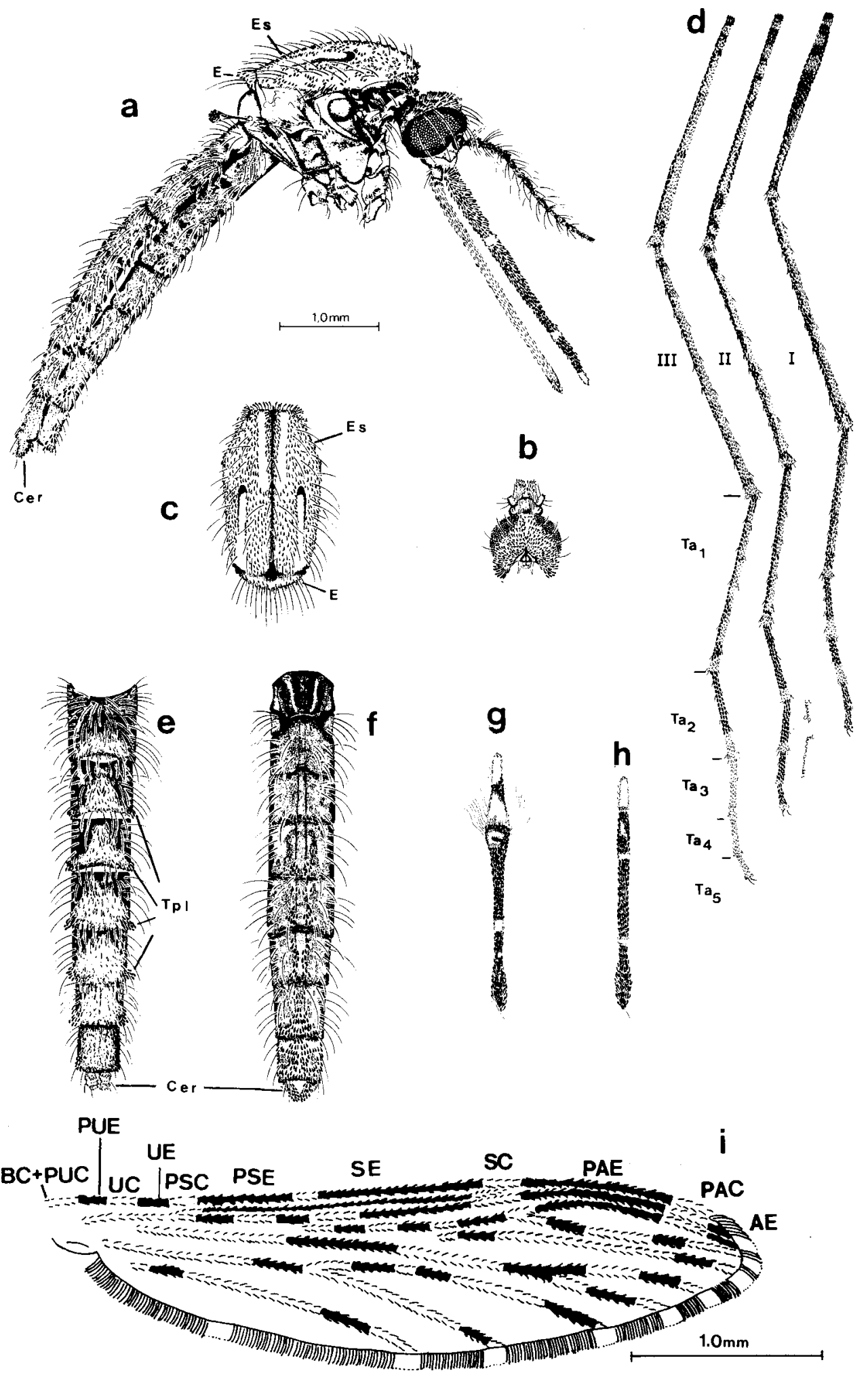
cerda ou grupo de cerdas situadas no local exato demonstrado nas figuras acima. Por exemplo: se a questão é verificar a presença da cerda pré-espiracular, devemos procurá-la na posição correta e não confundi-la com qualquer outra, ou mesmo com grupo de cerdas, que se encontre anterior ao espiráculo, como por exemplo as cerdas pós-pronotais.

As pernas dos mosquitos são longas e, como nos insetos em geral, compostas de coxa, trocanter, fêmur, tíbia e cinco tarsômeros ou artículos tarsais, numerados em ordem crescente de proximal para distal. O quinto artículo tarsal (Ta-V) é geralmente provido de um par de unhas semelhantes ou desiguais, denteadas ou não. Ainda no ápice do Ta-V podemos achar o empódio (Fig. 5).

A asa dos mosquitos (Fig. 1) apresenta escamas, em diferente quantidade e aspecto, nas suas veias e em seu contorno, neste último caso formando a franja da asa. Em seu contorno interno basal há duas dobras principáis que delimitam a calíptera e a álula. $\mathrm{Na}$ base da veia radial encontra-se uma porção mais espessa chamada remígio.

As veias têm nomenclatura própria conforme apresentamos na Fig. 1, e as principais chamam-se: costa, subcosta, radiais, medianas, cubital e anal, podendo ter ramificações que recebem números para facilitar a sua localização. Existem também veias transversais que, da mesma forma, recebem denominação, mas que não têm a mesma importância em taxonomia como as principais. As veias da asa da maioria dos Anophelinae são particularmente cobertas por grupos de escamas claras intercalados por outros de escamas escuras. Tais manchas de escamas têm grande importância taxonômica para essa subfamília e são denominadas conforme a Fig. 4. Dentre essas destacam-se, pelo emprego mais comum nas chaves dicotômicas, as manchas: umeral clara, pré-humeral escura, setorial escura e subcostal clara.

A nomenclatura usada para a asa é a proposta por Harback \& Knight (1980), com exceção das manchas na veia costa, cuja nomenclatura foi recentemente padronizada por Wilkerson \& Peyton (1990). Estes últimos autores verificaram que os nomes das manchas da asa, derivados das definiç̋̃es dadas para as espécies do gênero Anopheles, podem, em geral, ser empregados para as espécies, que possuem asas com manchas claras e escuras, dos gêneros Aedes, Aedeomyia, Culex, Orthopodomyia, Psorophora e Uranotaenia.

1 FIG. 4: Aspectos da morfologia externa do adulto - Anophelinae. a: cabeça, tórax e abdome da fêmea, vista lateral; b: cabeça, vista dorsal; c: mesonoto, vista dorsal; d: pernas; e, f: abdome, vistas dorsal e ventral, respectivamente; 8 : palpo maxilar do macho; h: palpo maxilar da fêmea; i: asa. I a III: pernas anterior, média e posterior, respectivamente; Cer: cercas; Es: escudo; E: escutelo; Ta1 a 5: Tarsos 1 a 5; Tpl: tufos póstero-laterais de escamas. Manchas da asa: AE: apical escura; BC + PHC: basal e préumeral claras (ou $B_{1}$ ); PAC: pré-apical clara; PAE: pré-apical escura; PSC: pré-setorial clara; PSE: pré-setorial escura; PUE: pré-umeral escura; SC: clara sub-costal; SE: setorial escura; UC: umeral clara (ou $B_{2}$ ); UE: umeral escura. 

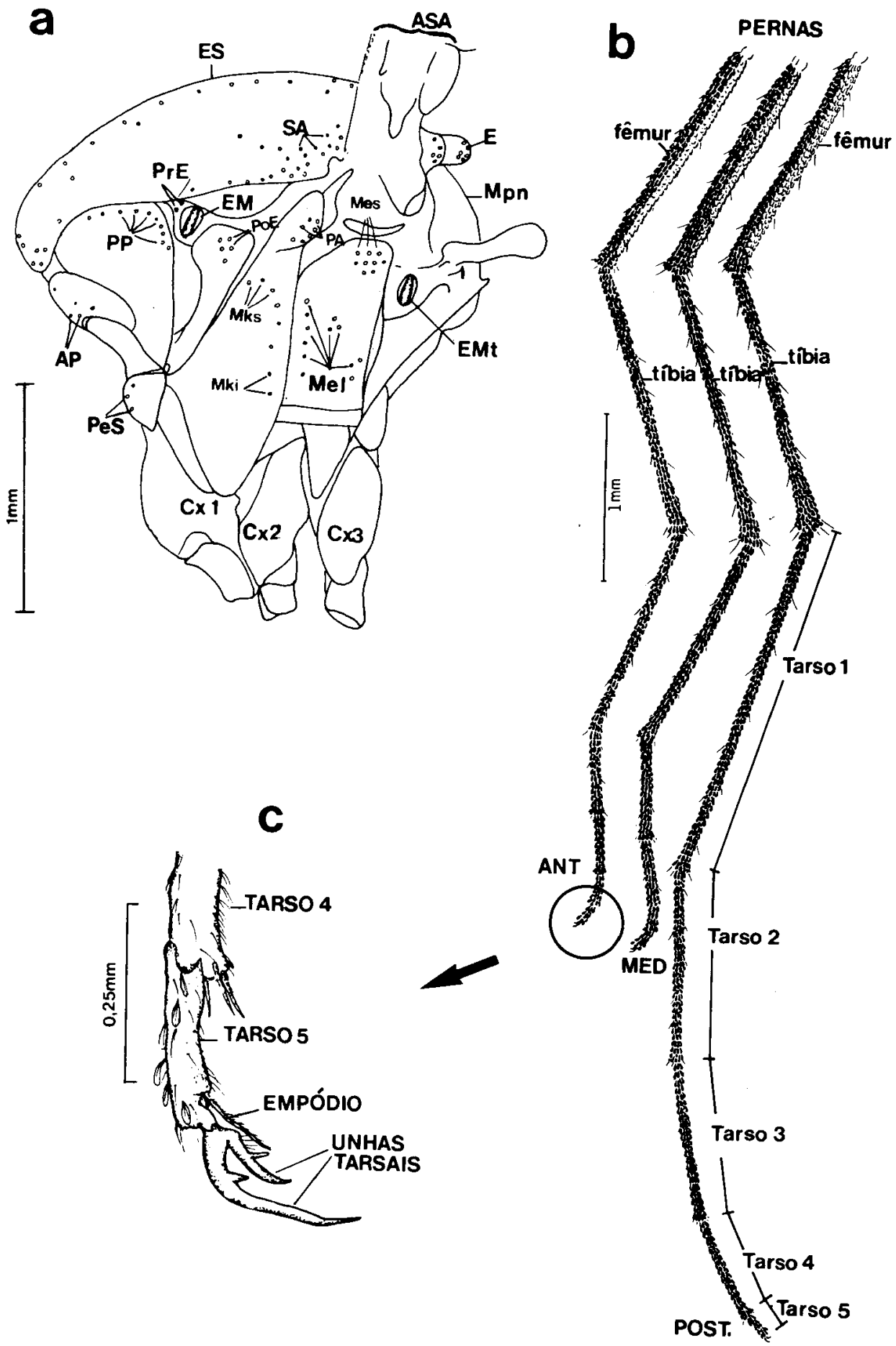


\section{Abdome}

O abdome dos mosquitos (Figs. 1 e 4) é formado de oito segmentos aparentes e mais dois reduzidos e modificados em ânus e genitália externa. Cada segmento abdominal é formado de duas placas em metade de anel - uma dorsal (tergito) e outra ventral (esternito) - unidas pela pleura ou membrana pleural. Os oito segmentos evidentes são mais facilmente identificáveis num exame dorsal do abdome, ou seja, contando-se os tergitos. Isto porque o primeiro esternito abdominal tem aparência diferente dos demais no que diz respeito ao revestimento de escamas e ornamentação por cerdas, além de poder estar alojado atrás do metatórax, o que muitas vezes faz com que ele seja erroneamente confundido como parte do tórax.

Em algumas espécies de mosquito podemos encontrar grupos de escamas nos ângulos posteriores dos tergitos, os quais são chamados tufos póstero-laterais de escamas (Fig.4).

A genitália feminina tem restrita utilização em sistemática. É muito menos complexa que a masculina e confere ao ápice do abdome um aspecto digitiforme ou um pouco pontiagudo, neste caso quando apresenta cercas (um par de lobos posterior ao tergito IX) desenvolvidas (Figs. 4 e 6 ).

O estudo da genitália masculina (Fig. 6) geralmente é de grande importância taxonômica, o que torna necessário conhecer algumas de suas partes principais.

No momento da cópula, o macho precisa segurar firmemente a porção final do abdome da fêmea para poder nela introduzir seu orgão copulador, o edeago. Este faz parte de um conjunto de escleritos que compõem o falosoma, dentre os quais se encontram os parâmeros, que ajudam na propulsão e retração do edeago durante a cópula. Há um par de escleritos - os paraproctos - que se articula com as placas do tergito $\mathrm{XI}$, que por sua vez são modificadas e pequenas.

Na verdade, são os gonocoxitos e os gonostilos (Fig. 6) que funcionam como pinça e seguram o ápice do abdome da fêmea para a cópula. Os gonocoxitos são as maiores unidades da genitália masculina e sua superfície medianodistal pode apresentar lobos variados, que por sua vez não raramente dão origem a cerdas normais ou modificadas de grande importância sistemática nos mosquitos. A base dos gonocoxitos também pode dar origem a lobos de aspecto variável, conhecidos como claspetes. Os gonostilos estão articulados na porção

1 Fig. 5: Aspectos da morfologia externa do adulto. a: Tórax, vista lateral, mostrando pontos de implantação das cerdas; b: pernas; c: ampliação do tarso 5. Ap: cerdas antepronotais; Cx1: coxa anterior; Cx2: coxa média; Cx3: coxa posterior; ES: escudo; EM: espiráculo mesotorácico; EMt: espiráculo metatorácico; E: escutelo; Mei: cerdas mesepimerais inferiores; Mes: cerdas mesepimerais superiores; MKi: cerdas mesocatepisternais inferiores; MKs: cerdas mesocatepisternais superiores; Mpn: mesoposnoto; PA: cerdas pré-alares; PeS: cerdas proepisternais; PoE: cerdas pós-espiraculares; PP: cerdas pós-pronotais (ou cerdas do pronoto posterior); PrE: cerdas pré-espiraculares; SA: cerdas supraalares. 


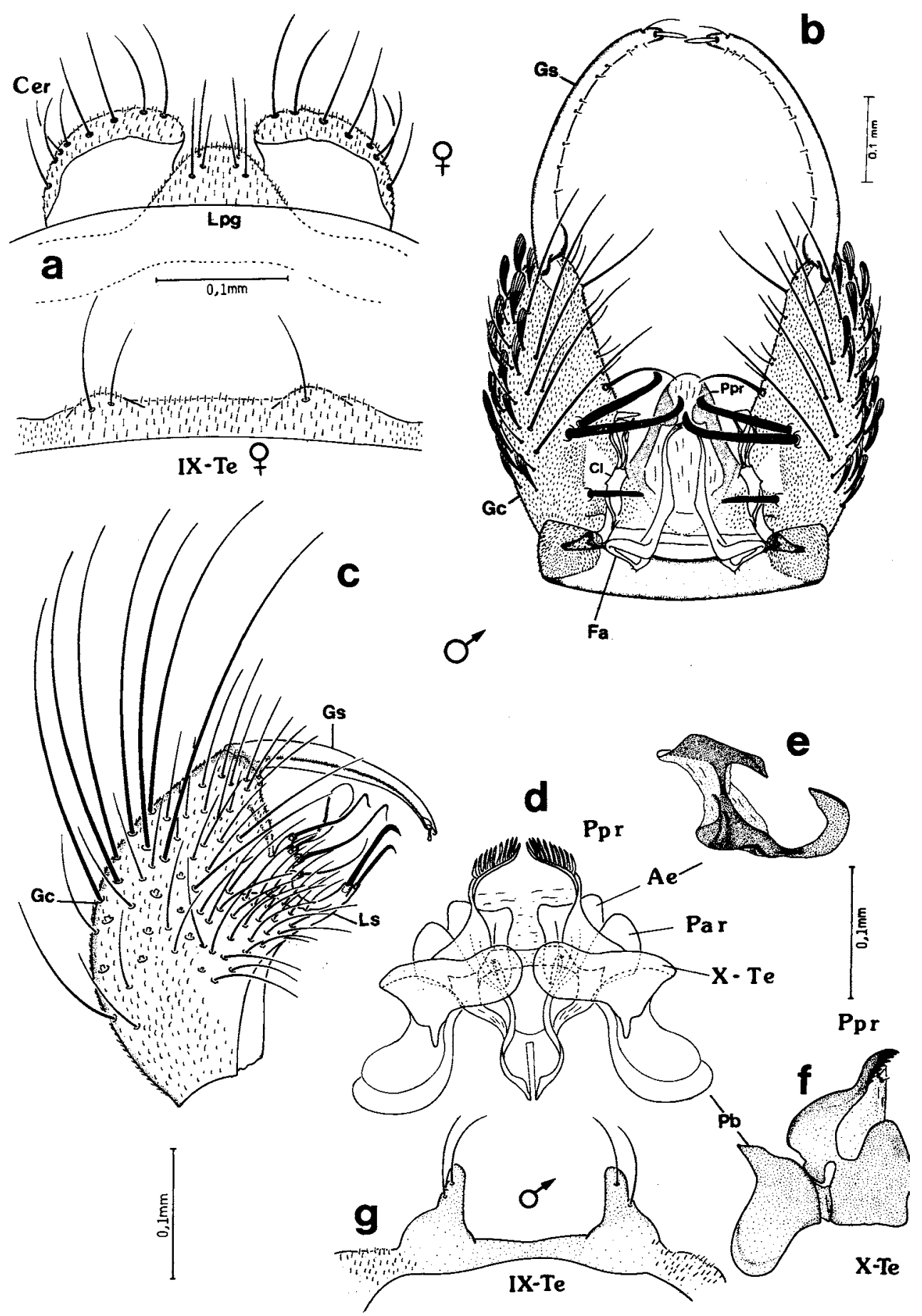


apical dos gonocoxitos e seu aspecto pode variar muito, como no caso dos Sabethini, auxiliando na identificação específica.

Todo esse conjunto da genitália externa masculina está cingido pelo tergito e esternito IX, sendo o primeiro usualmente bilobulado e de importância sistemática (Fig. 6).

A genitália masculina deve ser montada em bálsamo após dissecção de suas partes, de acordo com a orientação dada no item "Montagem em lâminas", p.(171).

\section{OVOS}

Os ovos dos mosquitos são elípticos ou ovais, muitas vezes com um lado achatado, plano ou mesmo um tanto côncavo, oposto ao lado convexo (Fig. 7). De modo geral, quando observados em corte transversal, são de contorno circular ou elíptico. Têm cor pálida no momento da oviposição, tornando-se escuros após alguns minutos, sendo que os inférteis geralmente não alcançam a tonalidade escura dos férteis. Os ovos podem ser colocados isoladamente ou em conjuntos, diretamente sobre a superfície da água, na face inferior de substratos flutuantes na água ou mesmo em local úmido bem próximo da água, dependendo do gênero de mosquito.

A "casca" dos ovos dos mosquitos, caracteristicamente impermeável, é conhecida como cório. $\mathrm{O}$ exocório geralmente apresenta ornamentações que auxiliam na identificação específica (Fig. 7). No caso particular dos Anophelinae, uma porção estreita e longitudinal do exocório lateral forma o que conhecemos como flutuadores, que contêm gomos ocos e impedem a submersão dos ovos (Fig. 7).

Na extremidade anterior dos ovos há um orifício no cório - a micrópila pelo qual o espermatozóide penetra para fecundar o óvulo (Fig. 7).

\section{LARVAS}

As larvas dos mosquitos, sempre aquáticas, têm aspecto vermiforme e coloração que varia entre o esbranquiçado, esverdeado, avermelhado ou mesmo

1 FIG. 6: Aspectos da morfologia externa do adulto. a: genitália feminina (Culicinae); b: genitália masculina (Anophelinae); c: genitália masculina (Culicinae), aspecto de um gonocoxito e gonostilo; d: genitália masculina (Culicinae), aspecto das placas copuladoras em vista dorsal, não desmembradas; e: genitália masculina (Culicinae), aspecto do aedeago, isolado; f: genitália masculina (Culicinae), aspecto ventral de algumas placas; g: genitália masculina (Culicinae), aspecto do tergito IX. Ae: edeago; Cer: cerca; Cl: claspete; Fa: falosoma; Gc: gonocoxito; Gs: gonostilo; Lpg: lobo pós-genital; Ls: lobo subapical do gonocoxito; Par: parâmero; Pb: placa basal; Ppr: paraprocto; $I X$-Te: tergito IX; $X$-te: tergito $X$. 

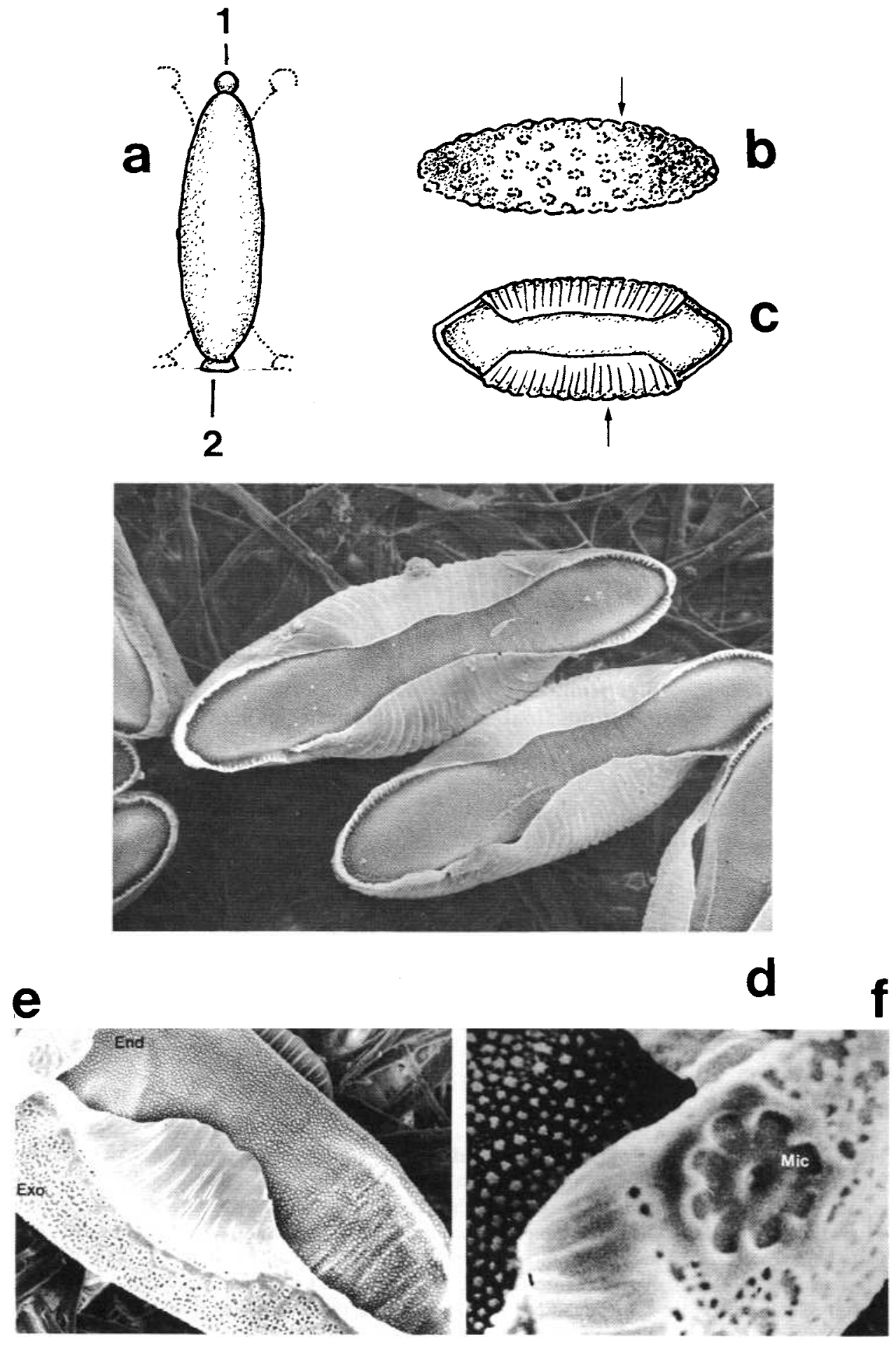
enegrecido. Seu corpo é nitidamente dividido em cabeça, tórax e abdome, sendo que os dois primeiros tagmas são mais globosos, enquanto o abdome tem aparência semicilíndrica e está dividido em nove segmentos (segmentos I-VIII, similares entre si, e X, diferenciado em lobo anal) (Figs. 8 e 9).

O corpo da larva apresenta cerca de 222 pares de cerdas, dispostas de maneira simétrica, que variam em aspecto (tamanho e número de ramificaçōes) e seu estudo denomina-se quetotaxia. Cada par de cerdas recebe uma numeração que se inicia na parte mediana dorsal e contorna o segmento até terminar na parte mediana ventral (Figs. 9 e 10). Convencionou-se denominar as cerdas, justapondo-se ao seu número o segmento ou porção em que ela está situada. Por exemplo: cerda 1-C (cerda 1 da cabeça), cerdas 4,7-P (cerdas 4 e 7 do protórax), cerdas 9-11-II (cerdas 9 a 11 do segmento abdominal II) e cerda 6-I-V (cerda 6 dos segmentos abdominais I a V). As cerdas têm função sensorial e auxiliam na flutuação.

A cabeça (C) (Figs. 8 e 9) é revestida por um conjunto de escleritos, cujos limites são evidenciados pelas suturas ou linhas que aparecem aí. É provida de um par de antenas e de olhos compostos por 1 a 5 grupos de ocelos laterais (Clements, 1963). Estes últimos aparecem como mancha escura bilateral, posterior a qual existe uma mácula, geralmente de aspecto reniforme, que persistirá na fase pupal e representa o olho composto do adulto em formação. No primeiro estágio, a larva é provida de um "dente" quitinoso no clípeo, que a auxilia no processo de eclosão.

Ao contrário dos adultos que possuem aparelho bucal adaptado à punção, as larvas dos mosquitos têm aparelho bucal do tipo mastigador-raspador; as peças bucais consistindo de epifaringe, mandíbulas, maxilas, hipofaringe e lábio. As mandíbulas e maxilas são placas robustas, dotadas de dentes e cerdas fortes, úteis à trituração dos alimentos e empregadas em estudos filogenéticos (Harbach \& Peyton, 1993).

À frente da cabeça encontram-se as escovas orais ou palatais, constituídas de um par de escovas laterais e um de escovas medianas (ventrais). Quase sempre ainda está presente uma escova anterior. Todas originam-se no palato (porção do labro) e são compostas de um conjunto de algumas centenas de filamentos. Tais escovas, quando em movimento, promovem correntes hídricas que trazem para a boca da larva as partículas que serão mastigadas. A abertura bucal da larva dos mosquitos é mais facilmente examinada pela face ventral da cabeça, quando se nota logo alguns de seus anteparos: os pares de maxilas e mandíbulas e o dorsomento (estrutura triangular com dentes nos lados anteriores) (Fig. 10).

1 FiG. 7: Aspectos dos ovos. a: Ovo de Culex; a1: gotícula apical; a2: cálice micropilar; b: Ovo de Aedes, com corpos coriônicos; c, d: Ovo de Anopheles, com flutuadores laterais (seta); e, f: Ovo de Anopheles, destaque para o cório e micrópila; End: endocório; Exo: exocório; Mic: micrópila. 

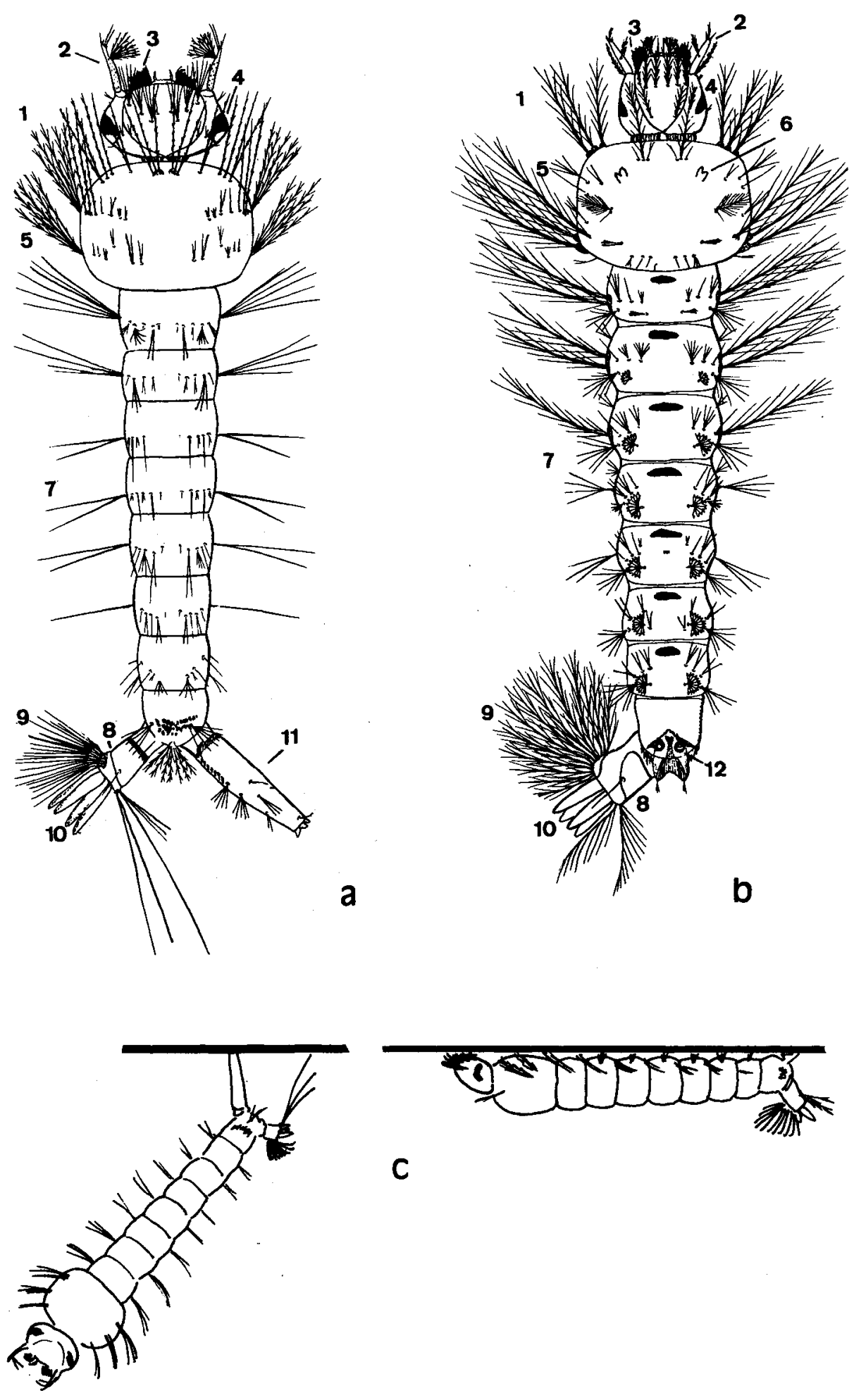

C 
Os três segmentos torácicos são identificáveis apenas pelos conjuntos de cerdas de cada um: Protórax (P), Mesotórax (M) e Metatórax (T) (Figs. 9 e 10). Seu tegumento, assim como o do abdome, é delicado, não esclerotizado, podendo apresentar-se nu ou espiculoso. Na região protorácica dorsal de mosquitos Anophelinae podem ser observados os órgãos flutuadores de "Nuttal \& Shipley" (Fig. 8). Numa larva, no final do quarto estágio podemos identificar as trompas respiratórias pupais em formação dentro do tórax.

Os segmentos abdominais são facilmente identificáveis, sendo que os sete primeiros - segmentos I-VII - apresentam cerca de 13 pares de cerdas cada um. No segmento VIII ocorrem apenas 5 pares de cerdas, além de um conjunto lateral de escamas, freqüentemente esclerotizadas a escova ou pente do segmento VIII (Figs. 9 e 10). Os segmentos I-VIII nos Anophelinae e VI-VIII dos Orthopodomyia possuem escleritos medianos dorsais denominados placas tergais (Fig. 10). O segmento $X$ é também conhecido como lobo ou lóbulo anal, pois nele termina o tubo digestivo da larva. Este segmento apresenta esclerito conhecido como sela, que pode cingir todo o segmento (sela completa) ou não (sela incompleta) (Fig. 10). No ápice deste segmento, ao redor do ânus, encontram-se quatro processos com aparência de língua, chamados papilas anais (Figs. 9 e 10).

Ainda ligado ao segmento VIII acha-se o sifão respiratório, tubo na extremidade do qual se abrem os espiráculos (Fig. 9). Não é desenvolvido em Anophelinae, nos quais existe um conjunto de placas esclerotizadas chamado aparato espiracular (Fig. 10). Sua área longitudinal mediana é formada principalmente pela placa espiracular, ladeada, anteriormente, pelas duas aberturas espiraculares. O sifão tem enorme importância taxonômica, pela sua forma, seu índice (resultado da divisão do comprimento do sifão pela sua largura medida no meio do órgão) e o aspecto e número dos espinhos que formam uma fileira de cada lado da sua parte pósterobasal (pecten). A base do sifão pode estar provida de uma estrutura quitinizada conhecida como acúleo (Fig. 9).

\section{PUPAS}

Nesta fase ocorre a metamorfose no mosquito: a larva de quarto estágio - que tem aparelho bucal mastigador, é desprovida de apêndices locomotores e de quem não se pode definir facilmente o sexo - , passa à fase pupal, durante a qual não se alimenta, e se transforma no adulto, o qual por sua vez se alimenta por punção, tem asas, patas e genitálias interna e externa completamente formadas.

Fig. 8: Aspectos da Larva. a: Larva de Culicinae; b: Larva de Anophelinae. 1: cabeça; 2: antena; 3: escova oral; 4: olho; 5: tórax; 6: 6rgão de Nuttall \& Shipley; 7: abdomen com oito segmentos; 8: lobo anal; 9: Cerda 4-X ou escova ventral do lobo anal; 10: brânquias ou papilas anais; 11: sifão respiratório; 12: espiráculos. c: Posição das larvas de Culicinae e Anophelinae quando respirando. 


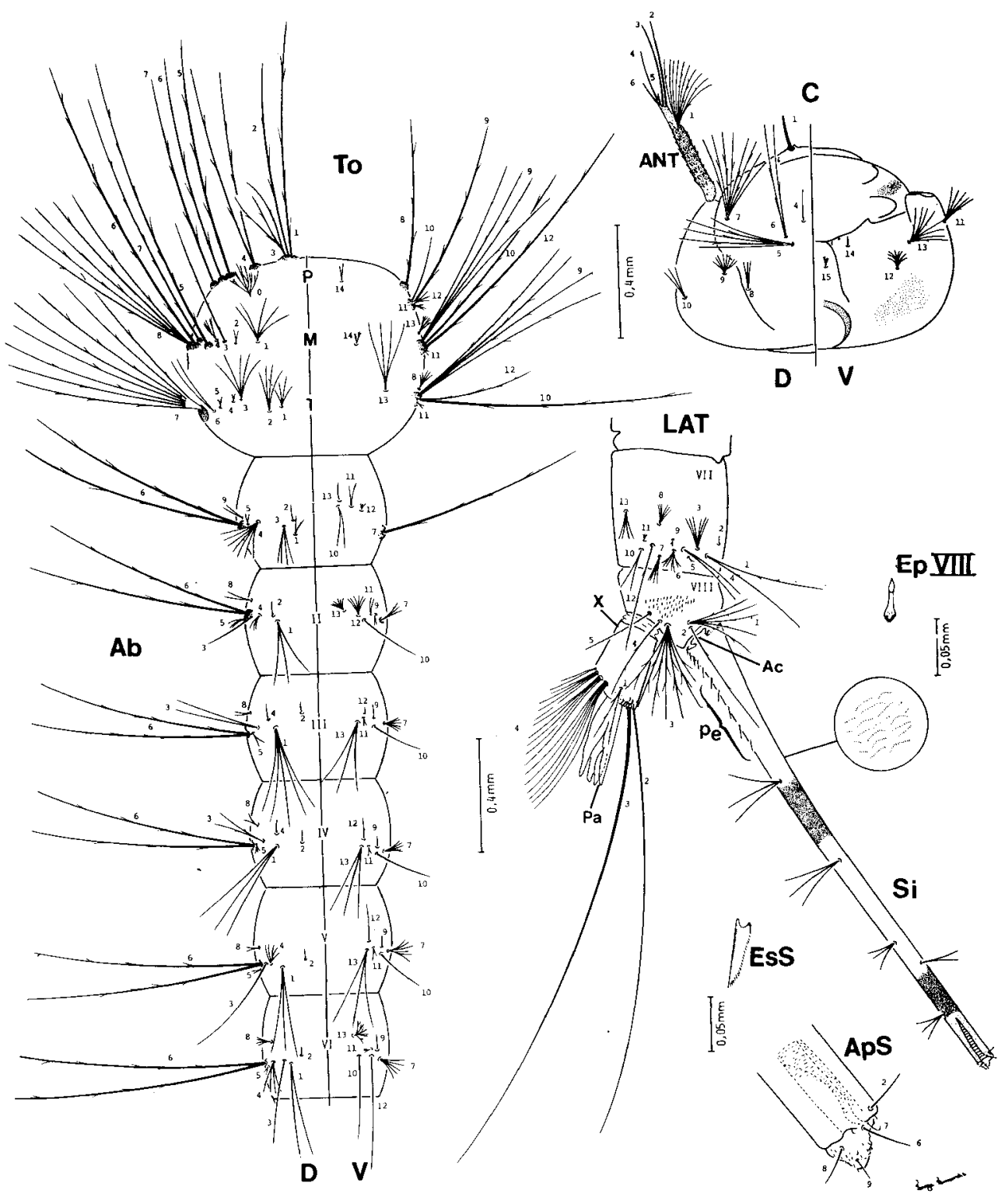

Fig. 9: Aspectos da larva de Culicinae (quetotaxia e morfologia). Ab: abdome; Ac: acúleo sifonal; ANT: antena; ApS: aparato sifonal (ápice do sifão); C: cabeça; D: vista dorsal; EPVIII: espinhos do pente do segmento VIII; EsS: espinho do pecten sifonal; LAT: vista lateral; M: mesotórax; P: protórax; Pa: papilas anais; Pe: pecten sifonal; Si: sifão; T: metatórax; To: tórax; V: vista ventral; I-VIII: segmentos abdominais; $X$ : segmento $X$ (ou lobo anal). 


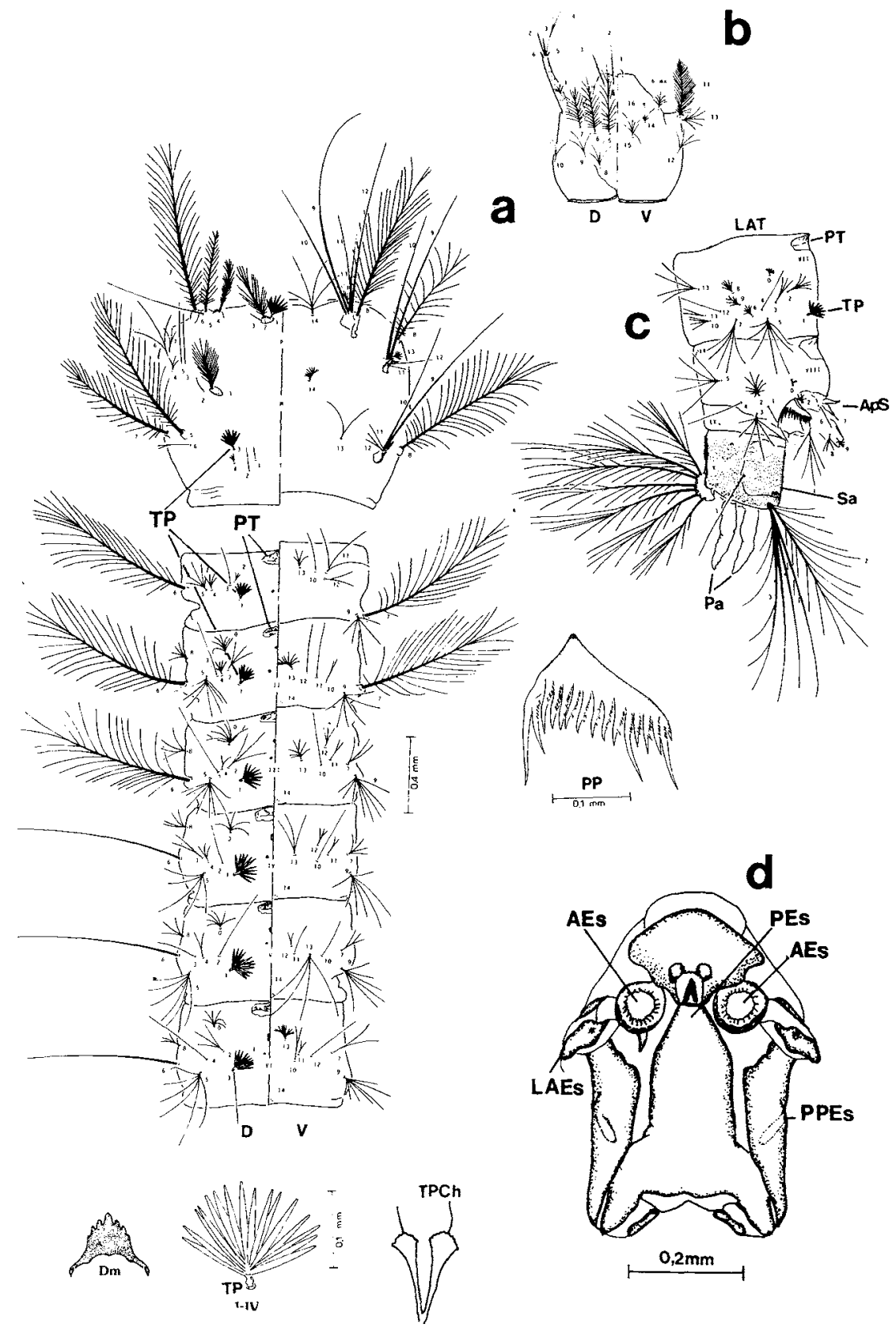

Fig. 10: Aspectos da larva de Anophelinae (quetotaxia e morfologia). a: tórax e abdome; b: cabeça; c: segmentos VII, VIII e $\mathbf{X}$, vista lateral; d: aparato espiracular, ampliaçāo, vista dorsal. AEs: abertura espiracular; ApS: aparato espiracular, vista lateral (vista dorsal ampliada); D: vista dorsal; Dm: dorsomento; LAEs: lobo antero-lateral da placa espiracular; LAT: vista lateral; M: mesotórax; P: protórax; Pa: papilas anais; PEs: placa espiracular; PP: placa de espinhos do pecten; PPEs: lobo postero-lateral da placa espiracular; PT: placa tergal; Sa: sela do lobo anal; T: metatórax; TP: tufo palmado; TPCh: tufo palmado de Chagasia, destaque ampliado de dois elementos do tufo; V: vista ventral; I-VIII e X: segmentos abdominais. 
As pupas têm aspecto de vírgula (Fig. 11.c). São bastante móveis quando perturbadas, mas estão quase sempre paradas em contacto com a superfície da água.

Seu corpo, que tem inicialmente a mesma cor da larva recém-transforma$\mathrm{da}$, escurece na medida que se aproxima o momento da emergência do adulto. Divide-se em duas porções: cefalotórax (CT) (cabeça + tórax) e abdome (dividido em 8 segmentos = Segs. I-VIII). Ambos, cefalotórax e abdome são providos de cerdas que, de acordo com seu aspecto, posição e número de ramificações, têm elevada importância sistemática (Fig. 11).

No cefalotórax existem duas estruturas tubulares chamadas trombetas ou trompas respiratórias, onde se abrem os únicos espiráculos da pupa. Ainda nesta porção do corpo vêem-se manchas escuras bilaterais que correspondem, respectivamente, aos olhos compostos e aos estemas (estes últimos bem menores e situados posteriormente aos primeiros). No final do abdome, isto é, no ápice do Seg.VIII, há um par de pás ou paletas que auxiliam a pupa na locomoção. Ligado a este segmento e ventral às paletas encontra-se o lobo genital, que no caso das pupas de fêmeas é geralmente bem pequeno, enquanto que nas pupas de machos é volumoso e parcialmente bilobulado, ou seja, aloja as estruturas maiores da genitália masculina: os gonocoxitos e gonostilos (Fig. 11).

Fig. 11: Aspectos da pupa (quetotaxia e morfologia). a: cefalotórax (parte), aspecto externo da exúvia pupal dissecada; b: Metatórax e abdome, aspectos dorsal e ventral da exúvia pupal de um macho, dissecada; c: pupa de macho, aspecto lateral da pupa não dissecada. ANT: antena (do adulto em formação); CT: cefalotórax; D: vista dorsal; LG: lobo genital; MT: metatórax; Oc: olho composto; Pe: pernas (do adulto em formação); PI: paleta (ou pá); Tb: trombeta (ou trompa resporatória) de Culicinae; TbA: trombeta de Anophelinae; V: vista ventral; I-VIII: segmentos abdominais. 


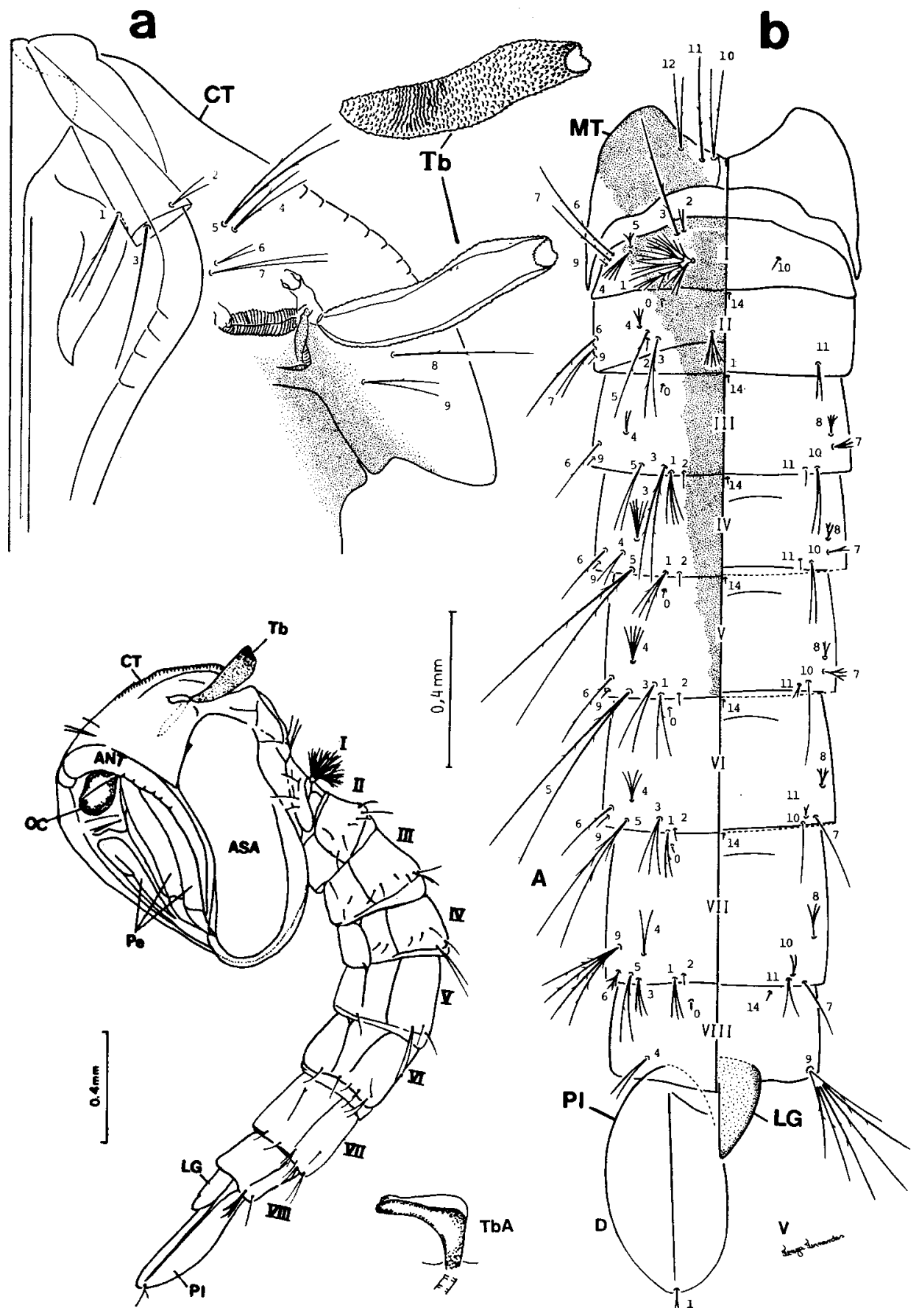




\section{BIOLOGIA E MORFOLOGIA INTERNA}

\section{ADULTOS}

\section{Alimentação e nutrição}

O metabolismo energético da grande maioria dos mosquitos, machos e fêmeas, depende da ingestão de carboidratos, usualmente provenientes de seivas, flores e frutos. $O$ acúmulo de glicogênio e triglicérides, que é determinante para o potencial de atividade e longevidade, depende diretamente desses carboidratos (Nayar \& Sauerman, 1973). O repasto sanguíneo das fêmeas está relacionado primordialmente ao desenvolvimento de ovos. Entretanto, existem mosquitos, como aqueles pertencentes ao gênero Toxorhynchites, que não sendo hematófagos, dependem exclusivamente da alimentação com carboidratos. Em algumas espécies hematófagas podem ocorrer raças capazes de produzir uma ou mais desovas iniciais não precedidas por ingestão de sangue, chamando-se esse fenômeno de autogenia. Por sua vez, o repasto sanguíneo pode também contribuir para aumentar a longevidade das fêmeas (Clements, 1963; Nayar \& Sauerman, 1975; Consoli, 1982). Edman et al. (1992) assinalam a ocorrência de múltiplos repastos sanguíneos em Ae. aegypti na Tailândia, em substituição à alimentação açucarada.

\section{APARELHO DIGESTIVO}

A região anterior do canal alimentar contém dois êmbolos de sucção que servem para a ingestão do alimento: bomba cibarial, situada sob o clípeo e provida em sua porção final de uma crista formada por espículos esclerotizados os dentes do cibário, bem como a bomba faringeana, musculosa, responsável pela pressão negativa gerada para a ingestão de alimentos (Fig. 12). O esôfago consiste em um tubo estreito que termina no esfincter "cardíaco". Logo após o esfíncter existem dois pequenos divertículos dorsais e um grande divertículo ventral (papo), todos revestidos por uma fina cutícula que os torna impermeáveis. Anexas ao intestino anterior acham-se as glândulas salivares, que estão organizadas em dois grupos de três ácinos com aspecto de sacos digitiformes, sendo o ácino mediano menor do que os laterais. A saliva de cada ácino é drenada por seu ducto próprio; estes, por sua vez, se unem em um ducto salivar comum 


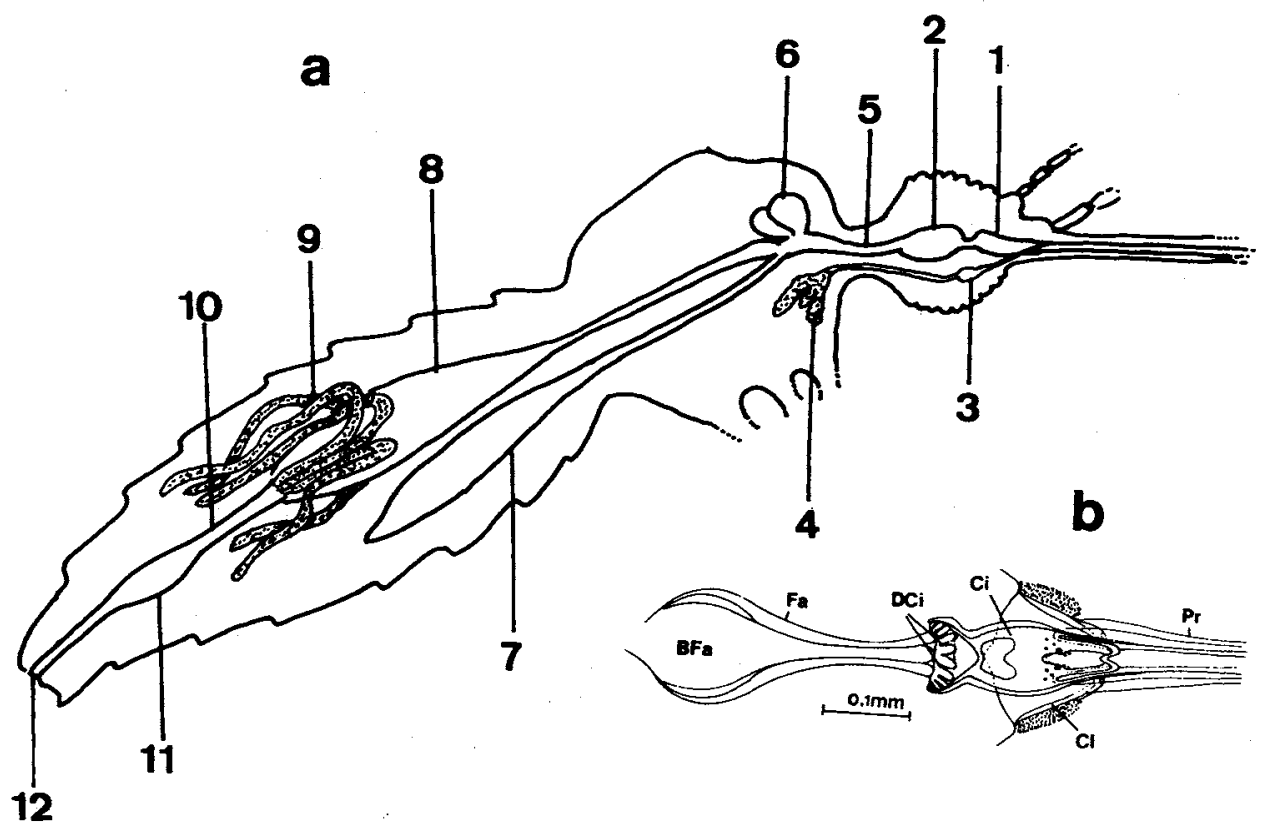

FiG. 12: Morfologia interna: a: Sistema digestivo de adulto. 1: bomba cibarial (Ci); 2: bomba faringeana (BFa); 3: bomba salivar; 4: glândula salivar; 5: esôfago; 6: divertículos dorsais; 7: divertículo ventral; 8: estômago ou intestino médio; 9: tubos de Malpighi; 10: fleo/cólon; 11: reto; 12: ânus. b: Cibário e faringe - vista dorsal. Cl: clípeo; DCi: dentes do cibário; Fa: faringe; Pro probóscide.

que conduz a saliva até a bomba salivar, em forma de bulbo, a qual se abre na base da hipofaringe. $O$ estômago ou intestino médio é altamente elástico e revestido internamente por um epitélio colunar de borda estriada, adaptado à secreção e absorção. Na parte posterior do estômago existe um poderoso esfíncter, a válvula pilórica, após a qual ligam-se os tubos de Malpighi, cuja estrutura e tamanho se mantêm praticamente intactos desde o último estágio larval, envolvidos na excreção e reabsorção de água. Nas fêmeas, o processo de excreção é ativo, principalmente após o repasto sanguíneo. Segue-se o intestino posterior, composto do ileo, do reto distendido ou ampola retal, onde se encontram as papilas retais (geralmente em número de quatro) $e$ ônus.

\section{ALIMENTAÇÃO COM CARBOIDRATOS}

Quando ingerem gotículas de carboidratos, os mosquitos mergulham a ponta da labela no líquido, sugando-os sem retrair o lábio. Os açúcares assim ingeridos são armazenados no divertículo ventral (Fig. 12), de onde passam lentamente para o estômago, sendo aí gradualmente digeridos. Esse mecanismo per- 
mite à fêmea manter vazio o estômago, pronto para receber o repasto sanguíneo. Numerosos carboidratos naturais podem participar da nutrição de mosquitos, estando aparentemente a glicose, sacarose, maltose e frutose entre os mais eficientes (Galum \& Fraenkel, 1957; Magnarelli, 1980; Consoli, 1982).

\section{ALIMENTAÇÃO SANGUINEA}

Somente as fêmeas dos mosquitos são hematófagas. Após pousarem sobre o hospedeiro em geral, selecionam cuidadosamente o local da picada com os órgãos sensoriais situados na labela (Christophers, 1960). O conjunto de estiletes bucais é então introduzido na pele do hospedeiro, ficando o lábio dobrado (Fig. 3). A saliva, concomitantemente inoculada, pode conter anticoagulantes, aglutininas e substâncias eventualmente alergênicas, mas não há evidências de que contenha enzimas digestivas (Clements, 1963). Na maioria das vezes ocorre sucção diretamente de um capilar e então o processo se completa em aproximadamente três minutos. Ocasionalmente o sangue pode ser sugado também a partir de uma hemorragia subcutânea produzida pelas peças bucais ("pool feeding") podendo, neste caso, durar mais do que dez minutos (Griffiths \& Gordon, 1952; O'Rourke, 1956; Consoli \& Williams, 1981). O sangue é sugado pela ação coordenada das bombas cibarial e faringeana (Fig. 12). O volume de sangue ingerido varia conforme a espécie: de 1,5 a $4,2 \mathrm{~mm}^{3}$, tem sido assinalados em Ae. aegypti e até $10,2 \mathrm{~mm}^{3}$ em $C x$. quinquefasciatus (Cx.pipiens fatigans) (Christophers, 1960; Freitas \& Guedes, 1961; Clements, 1963; Knaus et al., 1993).

\section{DIGESTÃO SANGUINEA}

A digestão sanguínea ocorre de maneira bastante rápida. Pouco após a ingestão, forma-se uma camada de material quitinoso, secretado pelas células do estômago, que separa a sua superfície interna do sangue ingerido e que constitui a membrana peritrófica. Essa membrana não se forma quando substâncias açucaradas passam para o estômago e são digeridas. Inicialmente grossa e viscosa, a membrana peritrófica solidifica-se rapidamente em uma camada fina e não e lástica. Se um segundo repasto sanguíneo ocorre antes que o primeiro tenha sido totalmente digerido, forma-se uma segunda membrana peritrófica circundando a primeira e o novo sangue ingerido. A membrana peritrófica é permeável as enzimas proteolíticas șcretadas pelas células estomacais e também aos produtos da digestão que são aí absorvidos. Quando a digestão se aproxima do seu final, a membrana torna-se novamente macia. Billingsley \& Rudin (1992) assinalam algumas diferenças na formação da membrana peritrófica entre Anopheles e Aedes, relacionando-as a diferenças na susceptibilidade desses mosquitos a Plasmodium beghei e Plasmodium gallinaceum, respectivamente.

\section{NECESSIDADES NUTRICIONAIS}

Muitos trabalhos confirmam a necessidade de proteínas para a produção de ovos nos mosquitos (Clements, 1963). Estudos indicam a necessidade de pelo menos dez aminoácidos essenciais na dieta para que ocorra a produção normal 
de ovos: arginina, isoleucina, leucina, lisina, fenilalanina, treonina, triptofano, valina, histidina e metionina. A produção de ovos aparentemente não aumenta quando são adicionados à dieta vitaminas e ácidos nucleicos, mas isso pode ocorrer em alguns casos em que são acrescentados sais de sódio e potássio (Dimond, Lea \& De Long, 1958). Há indícios de que em algumas espécies de mosquitos o tipo de sangue ingerido pode influenciar o tamanho da desova (Clements, 1963; Consoli et al., 1981).

\section{EXCREÇÃO}

Durante as primeiras duas horas após o repasto sanguíneo, o fluido aquoso que pode ser eliminado pelo ânus corresponde à descarga do excesso de liquido. Em alguns mosquitos, após pelo menos 12 horas do início da digestão sanguínea ocorre a eliminação de massas semi-sólidas de ácido úrico, concomitantemente com a reaksorção de líquidos ao nível do reto. $O$ corpo gorduroso pode funcionar também como órgão acumulador de ácido úrico.

\section{Reprodução}

\section{ACASALAMENTO}

Em relação ao acasalamento, os mosquitos podem ser divididos em dois grandes grupos: espécies estenógamas ou estenogâmicas, que são capazes de se acasalar em pequenos espaços, durante o vôo ou pousados sobre uma superfície, e espécies eurígamas ou eurigâmicas, cuja cópula depende da formação de enxames, os quais por sua vez necessitam de numerosas condições físicas e biológicas (Cambournac \& Hill, 1940, in Bates, 1949). Algumas espécies foram assinaladas como eurígamas facultativas e espécies estenógamas como Ae. aegypti e $C x$. quinquefasciatus já foram detectadas participando de enxames na natureza. Mosquitos verdadeiramente eurígamos, entretanto, raramente se acasalam em espaços restritos.

Os enxames podem ser formados por uma ou mais espécies e muitos fatores podem influenciar a sua formação: o estado fisiológico dos mosquitos, a intensidade luminosa, presença de pontos referenciais (objetos como postes, arbustos etc.), presença de correntes de ar e outros (Bates, 1949). Embora as cópulas intraespecíficas sejam a regra, cruzamentos interespecíficos podem ocorrer entre algumas espécies, como Ae. albopictus e Ae. aegypti (Nasci et al., 1989). O acasalamento pode se dar antes ou após a ingestão do primeiro repasto sanguíneo, mas é freqüuentemente anterior a este.

\section{FECUNDAÇÃO}

Após a cópula, os espermatozóides são armazenados nas espermatecas (Fig. 13) e serão utilizados pouco a pouco para fecundar os ovos durante o processo de postura. Os espermatozoides podem manter-se viáveis por muito tem- 
po (Clements, 1963; Andreadis \& Hall, 1980). Em Ae. fluviatilis foram assinaladas até 15 desovas fertilizadas por espermatozóides armazrnados anteriormente a primeira desova (Consoli et al., 1983).

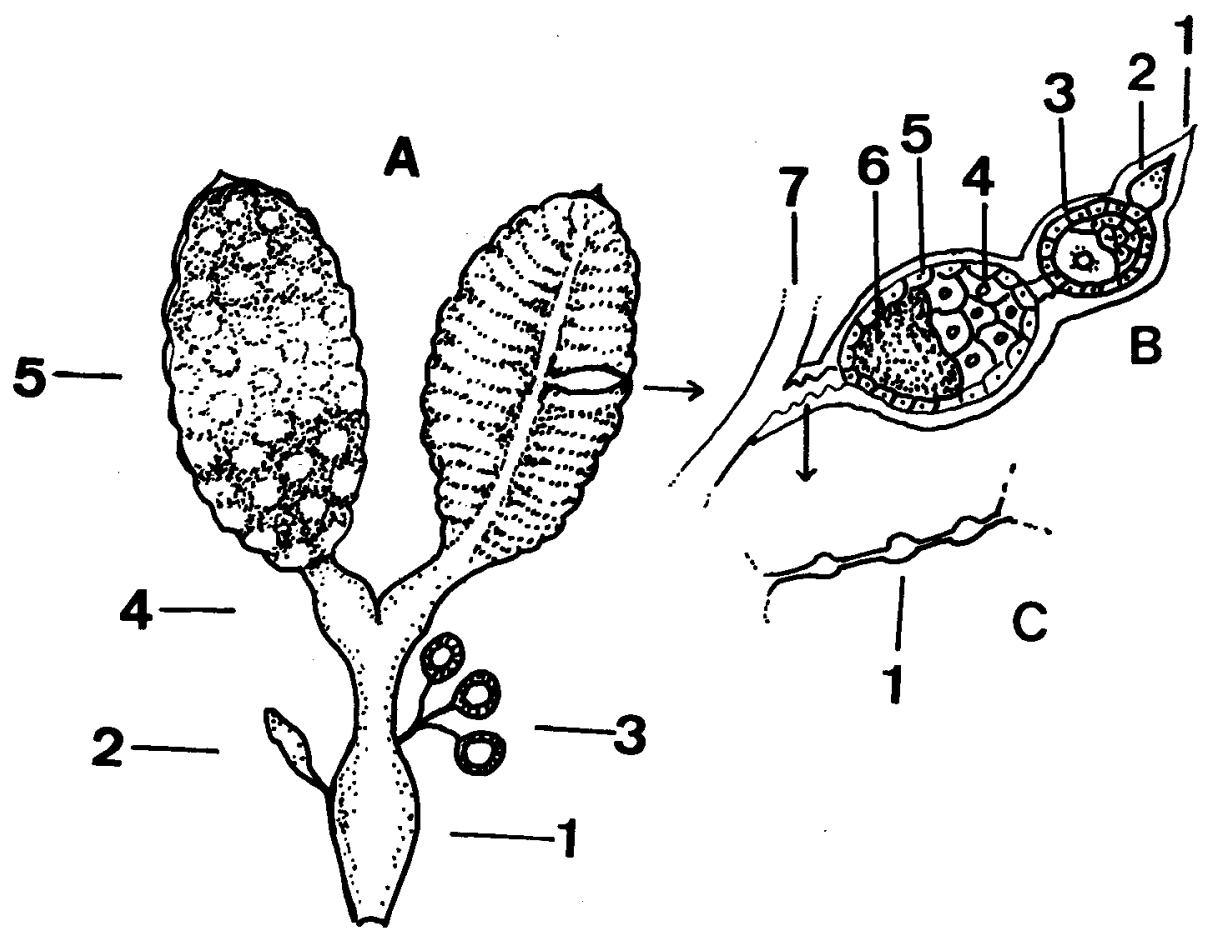

Fig. 13: A: Aparelho reprodutor feminino. 1: vagina; 2: glândula acessoria; 3: espermatecas; 4: oviduto lateral; 5: ovário. B: Ovariolo. 1: membrana ovariolar; 2: germário ou primeiro folículo; 3: segundo folículo; 4: trofócitos do terceiro folículo; 5: epitélio folicular; 6: ócito repleto de vitelo; 7: oviduto interno. C: Pedículo ovariolar. 1: dilatação.

\section{CONCORDÂNCIA E DISCORDÂNCIA GONOTRÓFICA}

Existe concordância gonotrófica quando cada oviposição é precedida por um repasto sanguíneo. Em algumas espécies ou populações, mais do que um repasto sanguíneo pode ser necessário para produzir a primeira desova, como por exemplo em algumas linhagens africanas de An. gambiae (WHO, 1961); embora prevaleça a concordância gonotrófica nas desovas seguintes, em linhagens autogênicas, a produção de ovos pode iniciar-se às expensas de reservas acumuladas durante a fase larvária, como ocorre em Culex pipiens var. molestus (Clements, 
1963). Em muitas espécies de mosquitos pode ocorrer, com freqüência variável, mais do que um repasto antecedendo a uma desova ou mais do que uma postura após somente um repasto (Andreadis \& Hall, 1980; Klowden \& Lea, 1980; Consoli et al., 1983).

\section{APARELHO REPRODUTOR MASCULINO}

Consiste de um par de testículos alongados situados dorsiventralmente na altura dos segmentos abdominais V e VI, cada qual consistindo de um folículo simples envolvido por uma membrana, no qual podem ser observadas as diversas etapas de desenvolvimento dos espermatozóides (Fig. 14). Cada testículo abre-se em um vaso eferente que por sua vez termina em um ducto deferente musculoso. Ambas as vesículas seminais encontram-se fundidas ao vaso deferente e ladeadas por um par de glândulas acessórias. Estas podem apresentarse, por sua vez, fundidas às vesículas seminais, em alguns Anopheles. No primeiro dia após a emergência processa-se uma rotação de 180 graus em toda a extremidade abdominal a partir do segmento VIII e incluindo a genitália (Christophers, 1960; Forattini, 1962).
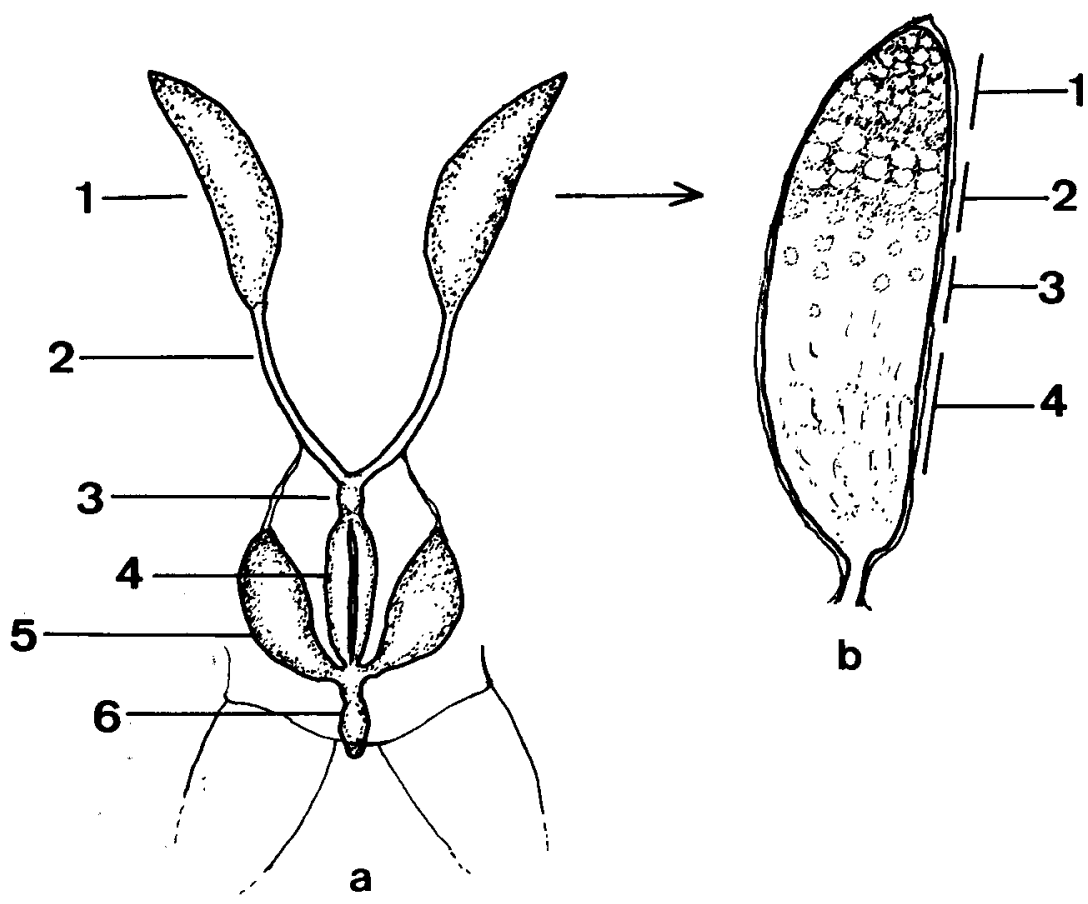

Fig. 14: a: Aparelho reprodutor masculino. 1: testículo; 2: vaso eferente; 3: vaso deferente; 4: vesículas seminais; 5: glândula acessória; 6: ducto ejaculador. b: Testículo. 1: espermatogônias; 2: espermatócitos; 3: região da meiose; 4: espermátides. 


\section{APARELHO REPRODUTOR FEMININO}

Consiste de um par de ovários dorsilaterais, situados na porção posterior do abdome, conectados por ovidutos laterais a um oviduto comum que se abre na câmara genital ou vagina (Fig. 13.a). Os ovaríolos desembocam na porção superior dos ovidutos laterais e são em número variável. Em Ae. aegypti foram estimados entre 50 e 150 (Colless \& Chellapah, 1960), podendo ocorrer mais do que 400 em Culex pipiens pipiens e acima de $500 \mathrm{em}$ alguns Anophelinae. Numerosas traquéias, abundantemente ramificadas, servem os ovários. As espermatecas quitinizadas, providas de ductos finos, fundidos ou não, abrem-se na vagina. Em Anophelinae ocorre uma só espermateca, mas em Culicinae podem ocorrer 1, 2 ou 3, de tamanhos iguais ou diferentes. Uma glândula acessoria e uma "bursa copulatrix" podem estar presentes e desembocar na vagina (Christophers, 1960; Clements, 1963; Forattini, 1962).

\section{Ovaríolo}

Cada ovaríolo consiste de um germário anterior seguido de um vitelário, envolvidos pela membrana ovariolar e pela membrana ovariana (Fig. 13.b). O germário contém células ainda pouco diferenciadas. O vitelário possui 2 ou 3 folículos, sendo cada qual formado por um oócito, 7 trofócitos e um epitélio folicular circundante.

\section{Desenvolvimento do folículo ovariano}

Esse desenvolvimento foi sistematizado por diversos autores, sob formas ligeiramente diferentes. Adotaremos a seqüência descrita por Detinova (1962):

$\mathrm{N}$ - folículo consiste de 8 células indiferenciadas, apresentando-se esférico.

I - o oócito pode ser claramente diferenciado dos 7 trofócitos, situados acima do mesmo.

II - 1 grânulos de vitelo aparecem em volta do núcleo do oócito. O folículo assume forma oval.

II - 2 aumentam consideravelmente as granulações de vitelo no citoplasma do oócito, que cresce e fica muito maior do que os trofócitos.

III - o oócito ocupa $3 / 4$ do folículo que se alonga. $O$ vitelo encobre totalmente o núcleo do oócito.

IV - folículo muito alongado, com os trofócitos ocupando apenas sua extremidade superior. A oogônia ocupa $9 / 10$ do folículo.

V - o cório recobre o ovo, aparecendo as características especificas da superfície do ovo, ficando os restos dos trofócitos restritos à extremidade proximal do folículo. 
Na ausência de repasto sanguíneo, geralmente ocorre uma parada no desenvolvimento dos ovariolos - diapausa ovariana - apos o estágio II - 1 de desenvolvimento, sendo o crescimento retomado após o repasto sanguíneo, que funciona como fator estimulante.

\section{IDADE CRONOLÓGICA E IDADE FISIOLÓGICA}

Define-se a idade cronologica pelo intervalo de tempo, medido em dias, vivido pelo inseto. Vários métodos, tais como a medida de desgaste das asas ou da escamação do corpo têm sido descritos para a avaliação da sobrevida na natureza, mas a grande variedade de circunstâncias as quais os insetos podem estar expostos, limita naturalmente a exatidão dessas medidas.

A idade fisiológica das fêmeas consiste no número de ciclos reprodutivos pelos quais estas passaram. É possível avaliar a paridade das fêmeas de mosquitos pela observação das características das traquéias ovarianas e dos ovaríolos (veja item "Dissecção de ovários e ovaríolos", p.(173)). Quando existe concordância gonotrófica e um intervalo de tempo razoavelmente constante entre os repastos sanguíneos e as posturas, pode-se calcular a idade cronológica aproximada a partir da idade fisiologica (Birley \& Boorman,1982).

\section{OVULAÇÃO, FERTILIZAÇÃO E OVIPOSIÇÃo}

$O$ epitélio folicular desaparece quando o ovo atinge a maturidade, ficando assim diretamente em contato com o oviduto. As contrações do oviduto são responsáveis pela ovulação. A oviposição segue-se imediatamente, ocorrendo a fertilização na passagem do ovo pelo oviduto comum, quando alguns espermatozóides liberados da espermateca penetram pela micrópila, sendo que um destes fertilizará o óvulo. Na falta de condições adequadas para a oviposição, ou mesmo espontaneamente, mosquitos podem reter seus ovos por muitos dias (Clements, 1963; Consoli et al., 1983). Em Ae. aegypti, a fertilidade de ovos retidos por mais de 15 dias declina rapidamente (Christophers, 1960). Em muitas espécies, choques físicos diversos, decaptação, arrancamento de uma asa ou envenenamento por éter ou inseticidas podem levar à oviposição, mesmo em ausência de água (Curtin \& Jones, 1961).

\section{COMPORTAMENTO DE OVIPOSIÇÃO}

A seleção do local de oviposição por parte das fêmeas é o principal fator responsável pela distribuição dos mosquitos nos criadouros e é da maior relevância para a distribuição das espécies na natureza. Fatores físicos, químicos e biológicos podem influenciar nessa seleção: intensidade luminosa ou ausência de luz (Jobling, 1935; Snow, 1971); o comprimento de onda da luz refletida, ou seja, as características de coloração apresentadas pelo criadouro em potencial (Miura \& Takahashi, 1973; Hilburn et al., 1983; Consoli et al., 1988); diferentes temperaturas (Dobrotworsky, 1959); graus de salinidade (Wallis, 1954; Clements, 1963; Consoli, 1980); presença de vegetais ou dos seus produtos (Judd Borden, 1980; Hobbs \& Molina, 1983; Consoli et al., 1989; Chadee et al., 1993); microorga- 
nismos ou os seus produtos (Ikeshoji et al., 1975) e substâncias relacionadas as formas imaturas de mosquitos (Kalpage \& Brust, 1973; Andreadis, 1977; Consoli \& Teixeira, 1988) e outros.

\section{Orgãos dos sentidos}

\section{VISÃo}

Os mosquitos possuem dois grandes olhos compostos que cobrem a cabeça em ângulo de aproximadamente $\mathbf{2 2 5}$ graus. Os olhos compostos são formados por unidades de visão chamados omatídeos, cujo número varia conforme a espécie: em Ae. aegypti podem ocorrer entre 421 e 492 (Christophers, 1960). Não há ocelos em culicídeos. Diversos trabalhos têm sido feitos sobre a acuidade visual e percepção de comprimentos de onda em mosquitos (Browne \& Bennett, 1981; Strichman, 1982). Snow (1971) assinala em Ae. aegypti duas áreas espectrais de maior sensibilidade luminosa: a primeira, na região verde-amarela (420 a 620 my) e a segunda na região ultravioleta ( 340 a $370 \mathrm{my}$ ), o que concorda com os achados correspondentes à maioria dos demais insetos.

\section{AUDIÇÃo}

Diversos autores comprovaram a relação entre o sentido da audição e as antenas - tanto o flagelo, que captaria vibrações, quanto o "6rgão de Johnston", situado no toro e que atuaria principalmente na amplificação sonora.

A fisiologia da audição em mosquitos é detalhadamente descrita por Clements (1963). Os machos desses insetos são atraídos pela frequência vibratória do batimento das asas das fêmeas da mesma espécie.

\section{QUIMIORRECEPTORES}

Quimiorreceptores de contato têm sido descritos em mosquitos, principalmente nas labelas da probóscide, bem como nos tarsos, do $2^{2}$ ao $5^{9}$ segmento, tanto em machos quanto em fêmeas (Evans \& Mellon, 1962).

Existem pêlos quimioreceptores na ponta das labelas e tarsos, capazes de distinguir soluções açucaradas e salgadas. Também a superfície interna da bomba cibarial, em machos e fêmeas de Ae. aegypti, contém numerosas células de função supostamente quimioreceptora (Clements, 1963). Aparentemente, as fêmeas utilizam os quimioreceptores dos tarsos para avaliar as características dos possiveis locais para a oviposição. Frings \& Hamrum (1950) não encontraram quimioreceptores sensíveis a soluções açucaradas nos palpos de Ae. aegypti.

\section{OUTROS ORGÃOS DOS SENTIDOS}

Como em outros Diptera, os halteres podem estar envolvidos na função de equilíbrio. Foram descritas cerdas profundas, possivelmente com função táctil nos tarsos de machos e fêmeas de diversas espécies de mosquitos (Christophers, 1960). 


\section{Longevidade}

A longevidade dos adultos depende de fatores intrínsecos e extrínsecos. Como fatores intrínsecos podemos citar as características específicas, a nutrição larval, o metabolismo do adulto e sua idade fisiológica. Os fatores extrínsecos mais determinantes são a temperatura, a umidade e a disponibilidade de carboidratos adequados para a nutrição. A luz também pode ter influência: Lanciani (1993) demonstrou que adultos de An. crucians sobrevivem significativamente mais tempo quando submetidos a fotoperíodos curtos. Em condiçōes naturais, a incidência de parasitas e predadores também é importante. Usualmente, as fêmeas sobrevivem por tempo sensivelmente mais longo do que os machos (Christophers, 1960; Clements, 1963; Consoli, 1982).

\section{OVOS}

Os ovos de mosquitos (Fig. 7 ) têm aspecto alongado, simetria bilateral e são envolvidos por uma casca composta de 3 camadas: a fina membrana vitelina interna, que envolve o núcleo, o cifoplasma e o vitelo, o endocório endurecido e grosso e o exocório fino e transparente que constitui o envoltório externo. $\mathrm{O}$ embrião depende da estrutura e das propriedades da casca para a sua proteção mecânica, passagem de gases respiratórios e resistência à perda de água. $O$ ovo recentemente posto apresenta-se cheio de grânulos de vitelo, separados por uma fina rede citoplasmática. O periplasma, junto à casca, apresenta-se livre de vitelo e alargado anterior e posteriormente.

Após a fertilização, todos os culicíneos apresentam um número diploide de cromossomas (geralmente $2 n=6$ ). Heterocromossomas sexuais foram descritos no gênero Anopheles, mas não foram assinalados em outros gêneros. Durante o desenvolvimento larval pode ocorrer poliploidia em vários tecidos e grandes cromossomas politênicos podem ser encontrados em glândulas salivares e tubos de Malpighi (Bates, 1949; Christophers, 1960; Clements, 1963).

\section{Desenvolvimento embrionário}

Processa-se usualmente logo após a oviposição, sendo influenciado principalmente pela temperatura e umidade. As características biologicas de cada espécie também são relevantes nesse processo, que em geral dura poucos dias. Indris (1960) descreveu detalhadamente o desenvolvimento embrionário de $C x$. pipiens.

\section{Eclosão e diapausa}

Em geral, os ovos que são postos diretamente na superfície da água eclodem assim que completam o seu desenvolvimento embrionário. Nesse caso estão, por exemplo, os ovos de Anopheles, Culex, Mansonia, Uranotaenia, Orthopodomyia e alguns Aedes. Entretanto, quando deixados fora da água os ovos de algu- 
mas dessas mesmas espécies podem apresentar diapausa facultativa e sobreviver por periodos variáveis, tais como An. gambiae por cerca de 10 dias (Deane \& Causey, 1943), An. punctimaculata por quatro semanas (Stone \& Reynolds, 1939) e Ae. fluviatilis por 30 dias (Consoli \& Williams, 1978). A diapausa na fase de ovo, caracterizada por uma suspensão temporária da eclosão após o término do desenvolvimento embrionário, ocorre naturalmente nos mosquitos que depositam seus ovos fora da água. É esse o caso de muitas espécies de Aedes, Haemagogus e Psorophora. Após um período de maturação inicial em ambiente úmido ( 30 a 40 horas para Ae. aegypti), que corresponde ao desenvolvimento embrionário, a resistência em ambiente seco nestes casos pode ser muito prolongada: em Ae. aegypti pode corresponder a mais do que um ano. Vários fatores extrínsecos, como fotoperiodicidade, temperatura e nutrição, durante a fase larvária da fêmea que ovipōe, têm sido relacionados com a incidência da diapausa (Pumpini et al., 1992). Para interromper a diapausa, vários estímulos podem ser necessários. $O$ principal parece ser o contato com a água ou a submersão nela; outros estímulos, como variações de temperatura, agitação da água e presença de microorganismos têm sido igualmente descritos. A eclosão larvária é auxiliada pelo atrito de um "dente" quitinoso situado dorsalmente na cabeça da larva de $\mathbf{l}^{\mathbf{P}}$ estágio contra a casca do ovo, e ainda o engurgitamento da larva juntamente com os seus movimentos pulsáteis (Bates, 1949; Christophers, 1960; Clements, 1963; Forattini, 1962).

\section{LARVAS}

\section{Respiração}

Embora aquáticas, as larvas de mosquitos respiram sempre o oxigênio do ar, necessitando para isso chegar à superfície da água ou ligar-se através de um sifão respiratório adaptado ao aerênquima de plantas aquáticas, como no caso de Mansonia (Fig. 24.c). As larvas desprovidas de sifão respiratório (Anophelinae) dispõe-se horizontalmente na superfície da água para respirar, auxiliadas por cerdas especialmente adaptadas, enquanto que aquelas providas de sifão respiratório situam-se quase perpendiculares (Figs. 8-10). Essa característica permite distinguir rápida e macroscopicamente as larvas de Anophelinae daquelas de outros mosquitos, na natureza. O sistema traqueal larvário consiste de dois grandes troncos longitudinais, conectados entre si e ramificados por todo o corpo. Quando a larva mergulha, os espiráculos se fecham para impedir a entrada de água no sistema. O peritrema espiracular estende-se em 5 lóbulos que se dobram para dentro por ocasião do mergulho e abrem-se quando a larva vem à superfície. O tempo que as larvas suportam longe da superfície varia com a espécie, idade e estado fisiológico. A capacidade de respiração cutânea parece variar muito nas diversas espécies: quando mantidas em água corrente, Ae. aegypti mostra-se capaz de sobreviver por 53 dias sem vir à superfície, mas $C x$. quinquefasciatus não foi capaz de fazê-lo por um dia. Sacos aéreos foram descritos em Mansonia e Orthopodomyia (Clements, 1963). 


\section{Alimentação e nutrição}

A maioria das larvas de mosquitos alimenta-se indistintamente do microplâncton presente em seus habitats, constituído de algas, rotíferos, bactérias, esporos de fungos, ou quaisquer partículas de matéria orgânica. Soluções de substâncias nutritivas parecem insatisfatórias para a nutrição larvária e existe controvérsia quanto à eficácia de suspensões coloidais (Christophers, 1960; Clements, 1963). A ingestão não seletiva de partículas por parte das larvas facilita a utilização de larvicidas por ação digestiva (Forattini, 1962).

\section{Sistema digestivo}

O sistema digestivo de larvas de mosquitos (Fig. 15) foi detalhadamente descrito por Christophers (1960), Jones (1960) e Clements (1963) e resumido, aqui, no item "Larvas", p.(29). A cavidade pré-oral é limitada dorsalmente pela superfície epifaringeal, anteriormente pelas escovas orais e lateral/lateroventralmente pelas mandíbulas e maxilas. Devido ao encurtamento do lábio e hipofaringe, a cavidade oral é mais aberta ventralmente. As mandíbulas são denteadas e as maxilas contém um pente capaz de limpar as escovas do lábio. Durante a ingestão de alimento as peças bucais movem-se juntas, produzindo de 180 a 240 batimentos por minuto. O movimento das escovas orais faz com que a água flua em direção à cabeça, trazendo as partículas de alimento. Partículas grandes demais para serem diretamente ingeridas podem ser trituradas com o auxílio das mandíbulas. Embora possam raspar superfícies com as suas peças bucais, a filtração constitui a forma mais comum de alimentação. Uma larva pode filtrar até 2 litros de água por dia (White, 1928 in Forattini, 1962). A faringe possui 2 pares de finos pentes na sua superfície interna e uma musculatura complexa adaptada a função de deglutição. Segue-se o esôfago, fino e muscular, que possui a extremidade distal dilatada e se liga ao intestino médio. Faringe e esôfago constituem o estomódeo, ou intestino anterior. O esfíncter cardíaco, existente no início do intestino médio tem por função evitar o regurgitamento e impulsionar o alimento para frente. Seguem-se o estômago e 8 cecos gástricos. As células que revestem o estômago são altas e possuem os bordos estriados, estando adaptadas à secreção e absorção. No revestimento dos cecos gástricos existem grandes células de citoplasma granular, provavelmente adaptadas à secreção. Usualmente não se encontram partículas em processo de digestão nos cecos gástricos, mas freqüentemente um fluido marron, algumas vezes contendo cristais. A membrana peritrófica, quitinosa, moldada na região da cárdia, estende-se por todo o estômago, que consiste em um tubo reto. Após o estômago abrem-se 5 tubos de Malpighi, compostos de grandes células achatadas com grandes núcleos. $O$ intestino posterior consiste na câmara pilórica, um íleo (ou intestino delgado), o reto (ou colon) e um ducto anal. A câmara pilórica possui forma de funil e liga-se ao íleo fino e recoberto de cutícula, que por sua vez desemboca no reto alargado. As glândulas salivares, cujo aspecto é variável nas diversas espécies, abrem-se junto ao lábio e hipofaringe, e são constituídas de grandes células, cujos núcleos podem conter cromossomas politênicos. 


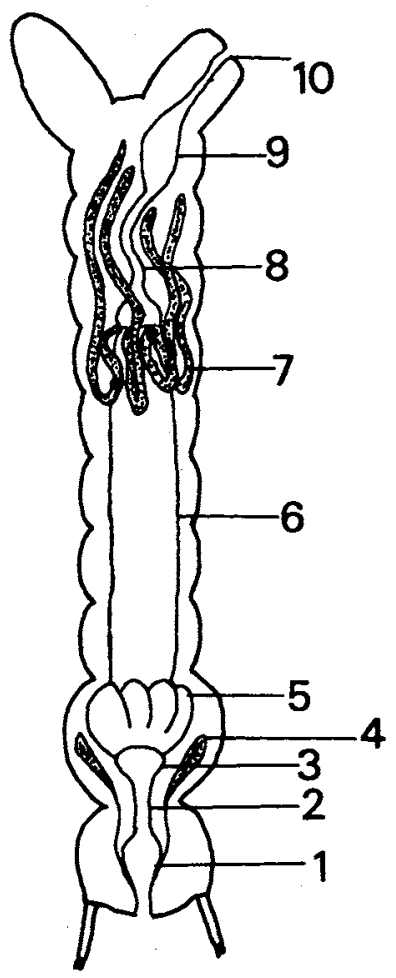

Fig. 15: Sistema digestivo da larva. 1: faringe; 2: esôfago; 3: proventrículo; 4: glândula salivar; 5: cecos gástricos; 6: estômago ou intestino médio; 7: tubos de Malpighi; 8: 1leo/colon; 9: reto; 10: ânus.

\section{Necessidades nutricionais}

Muitos trabalhos abordam as necessidades nutricionais de larvas de mosquitos: vários autores descrevem como essenciais cerca de 10 aminoácidos para as larvas de diversas espécies: arginina, histidina, isoleucina, leucina, lisina, metionina, fenilalanina, treonina, triptofano e valina. Sem lípides na dieta, as larvas não ultrapassam o $3^{\circ}$ estágio, sendo o colesterol, a cefalina e a lecitina especialmente importantes. Quanto às necessidades nutricionais relativas a carboidratos, os relatos são controversos, mas concordam em que a ausência destes pelo menos retarda o desenvolvimento larvário. Dentre as vitaminas, parecem essenciais a biotina, colina, ácido nicotínico, ácido pantotênico, riboflavina, piridoxina e tiamina. O ácido fólico parece importante no processo de pupação (Lea \& Delong, 1958; Singh \& Brown, 1957; Clements, 1963). 


\section{Reservas nutricionais}

O principal órgão de armazenamento é o corpo gorduroso, que se localiza sob a epiderme nas regiōes torácica e abdominal. As reservas consistem principalmente em proteínas e glicogênio e são de primordial importância para o desenvolvimento dos estágios ulteriores de pupa e adulto.

\section{Excreção e desintoxicação}

Os fluidos passam da hemolinfa aos tubos de Malpighi e daí para o reto, onde algumas substâncias são reabsorvidas e o restante é eliminado. $O$ ácido úrico pode ser eliminado através dos tubos de Malpighi ou ser acumulado no corpo gorduroso. A capacidade de desintoxicação, ou seja, a transformação de substâncias tóxicas em não tóxicas, relatada em várias espécies, constitui um importante mecanismo de resistência a inseticidas. A transformação de DDT em DDE não tóxico, foi encontrada em muitas espécies de Anopheles, Aedes e Culex (Brown, 1960). A eliminação de inseticidas através da extrusão da membrana peritrófica pelo ânus (Abedi \& Brown, 1961) ou a absorção lenta de substâncias tóxicas, como mecanismos de resistência foram assinalados em Ae. aegypti resistentes ao Malation (Matsumura \& Brown, 1961).

\section{Mecanismos de regulação}

Os mecanismos de regulação foram estudados principalmente em Ae. aegypti (Ramsay, 1950; Clements, 1963). Os fluidos derivados da hemocele passam através dos tubos de Malpighi, acumulam-se na câmara pilórica e devido ao peristaltismo no intestino posterior vão para o reto, onde uma parcela será reabsorvida e outra eliminada. Movimentos antiperistálticos levam também líquidos ao estômago, onde vão situar-se entre a membrana peritrófica, o epitélio intestinal e cecos gástricos, podendo ser aí reabsorvidos. É possível que os cecos gástricos sejam o principal local de reabsorção de água no intestino médio.

Há dados que mostram que o potássio circula na mesma seqüência, embora a pressão osmótica seja variável em cada órgão. As 4 papilas anais que circundam o ânus têm grande importância na adaptação das larvas às condições de salinidade do ambiente. Essas papilas consistem de expansões da superfície do corpo, possuindo lúmem contínuo com a hemocele. Mosquitos de água salobra usualmente possuem papilas anais muito reduzidas. Essa redução pode ser induzida também em outras espécies, habituando-as a concentrações progressivamente mais elevadas de salinidade (Wigglesworth, 1933).

\section{Larvas predadoras}

Embora do ponto de vista microscópico todas as larvas de mosquitos possam ser consideradas predadoras, pois podem ingerir inúmeros organismos através de seus mecanismos habituais de ingestão, somente as larvas que atacam ativamente outros organishos vivos são costumeiramente consideradas 
predadoras. Esses ataques podem por vezes incluir indivíduos da mesma espécie. Espécies predadoras são comuns nos gêneros Toxorhynchites, Trichoprosopon, Sabethes, Psorophora e Culex (Lutzia) (Lane, 1953b; Bates, 1949; Forattini, 1962).

\section{Desenvolvimento larvário}

Todas as larvas de mosquitos passam por 4 estágios evolutivos, sendo o último destes o mais longo. Os machos têm, em média, um desenvolvimento larvário mais rápido do que as fêmeas.

Logo após a eclosão, as partes destinadas a uma quitinização mais forte, como a cápsula cefálica e o sifão respiratório, crescem aceleradamente até o endurecimento da quitina, enquanto as partes moles crescem mais lenta e continuamente. $O$ tecido nervoso e o corpo gorduroso crescem por aumento do número de células, enquanto os tecidos das papilas anais, tubos de Malpighi e glândulas salivares geralmente não sofrem divisões celulares, mas crescem devido ao aumento de tamanho de suas células. As gônadas, destinadas aos adultos, começam a se desenvolver lentamente nas primeiras fases larvárias, acelerando suas mitoses no $4^{\circ}$ estágio larval (Clements, 1963).

\section{Principais fatores ambientais que interferem no desenvolvimento larvário:}

\section{TEMPERATURA}

Entende-se por temperatura ótima aquela na qual o desenvolvimento ocorre com o mínimo de mortalidade e perda de fertilidade nos adultos resultantes. Essa não será necessariamente a temperatura de desenvolvimento mais rápido.

Constantes flutuações de temperatura são prejudiciais ao desenvolvimento larvário.

A temperatura ótima para o desenvolvimento varia para cada espécie, encontrando-se entre 24 e $28^{\circ} \mathrm{C}$ (temperatura ambiente do ar) para a maioria dos mosquitos tropicais.

\section{LUZ}

Algumas espécies de mosquitos não alcançam a maturidade em ausência de luz (Trenz, 1934; Frost et al., 1936), entretanto a maioria das espécies estudadas pode desenvolver-se em completa escuridão. Esse fato pode ter relevância no caso de vetores urbanos como Ae. aegypti e Cx. quinquefasciatus, que desta forma podem desenvolver-se em galerias de água ou esgoto, onde haja pouca ou nenhuma luz.

Existem espécies umbrófilas, que preferem criadouros sombreados (Ex: An.oswaldoi) ou heliófilas, que preferem os ensolarados (Ex: Ae. fluviatilis). As 
larvas podem apresentar maior atividade na luz (fotocinese) ou procurar espontaneamente as áreas mais sombreadas dos criadouros (fototeletaxia) (Bates, 1949).

\section{SALINIDADE}

A tolerância de larvas de mosquitos à salinidade varia conforme a espécie e por vezes difere em populações da mesma espécie. Raras são as espécies encontradas na natureza criando-se em elevadas concentrações salinas, como Ae. natronius, mosquito africano que se cria naturalmente em concentrações de até 3,9\% de cloreto de sódio (Beadle, 1939). Muitos experimentos laboratoriais comprovam a capacidade de adaptação ou tolerância de larvas a diversas concentrações salinas (Bates, 1949; Christopher, 1960; Consoli, 1980). Na natureza, entretanto, parecem predominar as concentrações salinas muito baixas em criadouros de mosquitos (Milward de Andrade, 1959 a, b; Bates, 1949).

\section{POLUENTES ORGÂNICOS E INORGÂNICOS}

A tolerância a poluentes varia muito, sendo em geral mais elevada nas espécies domésticas e peridomésticas. Os mosquitos do gênero Anopheles da região neotropical, em geral são muito sensiveis a produtos nitrogenados e por isso dificilmente encontrados em águas poluídas. $C x$. quinquefasciatus, por sua vez, mostrou-se capaz de pupar em até 1,5\% de sulfato de amônia (Bates, 1949). A presença de substâncias oleosas na água é prejudicial às larvas por dificultar ou impedir mecanicamente a sua respiração. Vários tipos de óleos minerais e vegetais (óleo de coco) combinados ou não com detergentes foram utilizados na primeira metade do século, para o controle de larvas de mosquitos (Shannon \& Frobisher, 1931; Christophers, 1960).

\section{MOVIMENTO DA ÁGUA}

As larvas de mosquitos não são realmente adaptadas a viver em água em movimento; mesmo as espécies encontradas em rios, riachos, córregos etc. - na verdade vivem em microclimas de água quase parada. Algumas espécies, principalmente de Anopheles, possuem forte tigmotropismo, isto é, tendência de aderirem a pedras e outros objetos, facilitando dessa forma a sua resistência a eventuais correntes (Bates, 1949).

\section{RELAÇÕES COM A VEGETAÇÃO NÃO AQUÁTICA}

Várias espécies de mosquitos podem utilizar-se de água acumulada em buracos de árvores, internódios de bambu, bromeliáceas, cascas de frutos ou folhas caídas, para criadouros. É notável a adaptação de Anopheles do subgênero Kerteszia aos criadouros em bromeliáceas, principalmente no sul do Brasil. Plantas que sombreiam criadouros podem favorecer as espécies que buscam criadouros sombreados ou prejudicar aquelas que necessitam de criadouros ensolarados (Bates, 1949; Zulueta, 1950). 


\section{RELAÇÕES COM A VEGETAÇÃO AQUÁTICA}

As plantas aquáticas podem interferir negativamente nos criadouros de mosquitos, quando cobrem a superfície limitando a área para a respiração e a oviposição, como aquelas pertencentes aos gêneros Lemna, Azolla, Trapa etc., ou positivamente, oferecendo-lhes proteção, como acontece com An. darlingi nas raízes de Pistia e Eichornia. Mosquitos do gênero Mansonia possuem um sifão respiratório especialmente adaptado para utilizar o ar contido no aerênquima de plantas aquáticas (Fig 24c). Algas microscópicas podem constituir alimento para as larvas e Utricularia, por sua vez, pode predar larvas de mosquitos (Bates, 1949; Forattini, 1962; Furlow \& Hays, 1972; Hobbs \& Molina, 1983).

\section{PRODUTOS QUÍMICOS DERIVADOS DE PLANTAS}

Recentemente, têm sido feitos trabalhos sobre a influência de diversos derivados de vegetais na sobrevida de larvas de mosquitos e na seleção dos criadouros por parte das fêmeas, por ocasião da oviposição. Vários vegetais ou seus extratos podem possuir atividade larvicida, associada ou não a efeito atrativo ou repulsivo sobre as fêmeas que buscam um local para desovar. Armadilhas de oviposição têm sido propostas com base nesses efeitos (Angerilli, 1980; Judd \& Borden, 1980; Consoli et al., 1988a).

\section{RELAÇÕES COM ANIMAIS}

Além dos microorganismos que podem servir de alimento para as larvas, outros animais podem ser parasitas ou predadores de larvas de mosquitos. Os principais serão abordados no capítulo referente ao controle biológico. 


\section{Criadouros}

Existem diversas classificações para os criadouros de mosquitos. Adotaremos aquela descrita por Forattini, 1962.

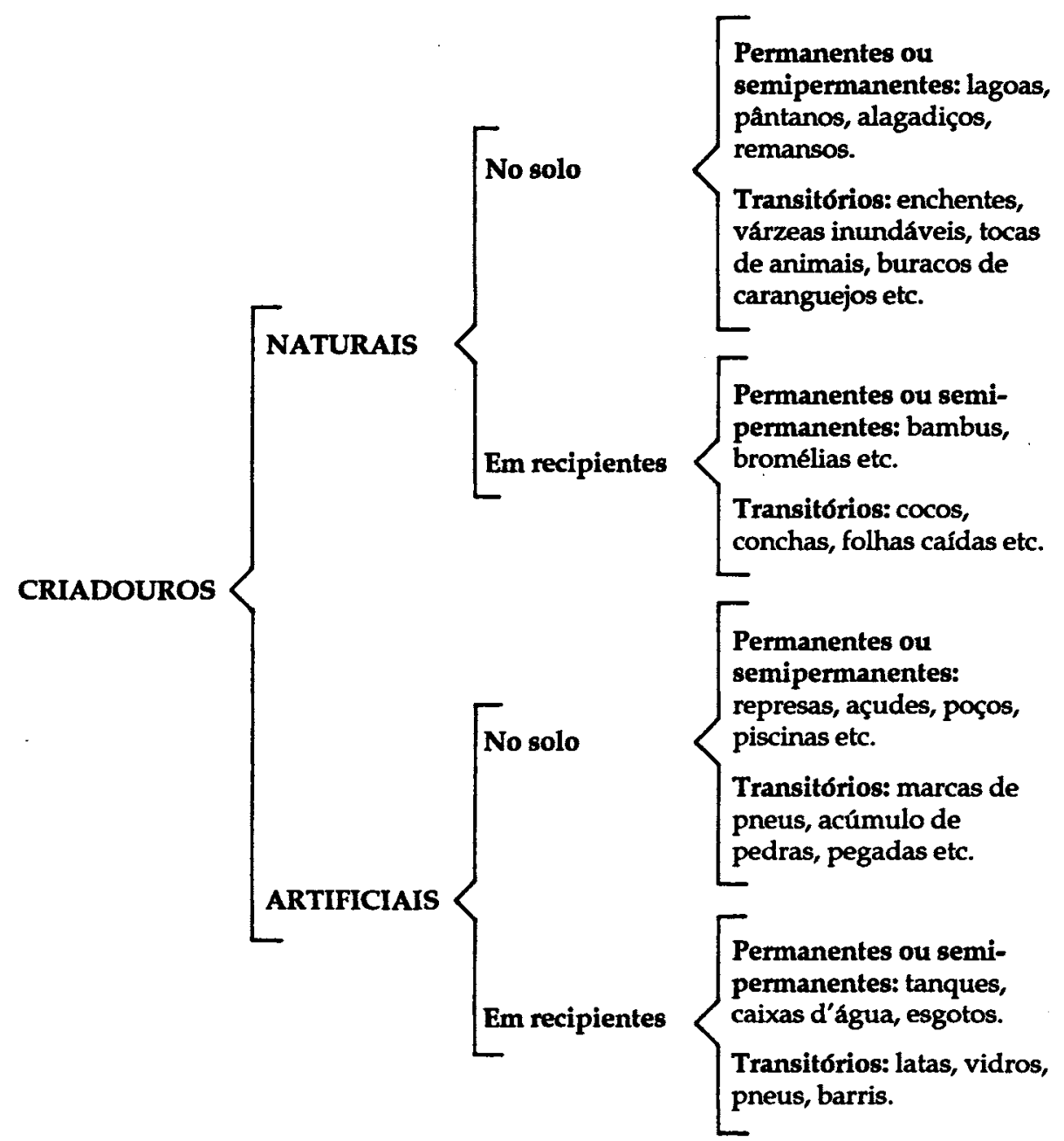




\section{CLASSIFICAÇÃO E PRINCIPAIS ESPÉCIES DE IMPORTÂNCIA} SANITÁRIA

Os mosquitos - família Culicidae - estão agrupados em três subfamílias, separadas conforme a chave apresentada a seguir, adaptada a partir da proposta por Lane (1953):

1. Probóscide recurvada para baixo e para trás (Fig. 2).

Clípeo mais largo que longo Toxorhynchitinae

Probóscide reta (Figs. 1, 2.a, b e 4), raramente curva, mas nunca voltada para trás; clípeo menos largo que longo.

2. Fêmeas com palpos muito mais curtos que a probóscide; margem posterior do escutelo sempre trilobada; primeiro tergito abdominal com escamas (Figs. 1 e 2) Culicinae

Fêmeas com palpos de comprimento semelhante ao da probóscide; margem posterior do escutelo arredondada (exceto no gênero Chagasia); primeiro tergito abdominal sem escamas (Fig. 4). Anophelinae

Os nomes dos gêneros e subgêneros são aqui abreviados de acordo com Reinert (1975).

\section{SUBFAMÍLIA TOXORHYNCHITINAE}

Esta subfamília inclui apenas um gênero: Toxorhynchites Theobald, com três subgêneros - Ankylorhynchus Lutz, Lynchiella Lahille e Toxorhynchites Theobald. Esse gênero encontra-se representado em todas as regiões zoogeográficas e 
corresponde a mosquitos coloridos, grandes, não hematófagos na fase adulta e vorazes predadores da fase larvária. Devido a esses hábitos, os Toxorhynchites obviamente não têm importância na transmissão de patógenos.

Há, pelo menos, duas referências importantes sobre a subfamília Toxorhynchitinae: Costa Lima et al. (1962) e Knight \& Stone (1977).

As duas outras subfamílias de mosquitos incluem um grande número de insetos de importância médica. Os componentes da subfamília Anophelinae são conhecidos como anofelíneos, ou simplesmente anofelinos, enquanto que os da subfamília Culicinae são os culicíneos. Além das diferenças citadas na chave acima, os culicíneos são diferenciados dos anofelinos de acordo com as descrições a seguir e nas figuras 1, 4, 7-10.

\section{PRINCIPAIS DIFERENÇAS ENTRE ANOFELINOS E CULICÍNEOS}

ANOFELINOS

\section{CULICÍNEOS}

\section{ADULTOS}

Pousam com o corpo e a probóscide em linha reta, quase em ângulo reto com o substrato.

Fêmeas com palpos longos (Fig. 4).

Machos com palpos longos, com últimos segmentos clavados (Fig. 4).
Pousam quase paralelamente ao substrato.

Fêmeas com palpos bem curtos (Fisss. 1 e 2).

Machos com palpos longos na maioria das espécies, com últimos segmentos não dilatados (Fig. 2).

\section{OVOS}

Postos isoladamente e apresentando flutuadores (Fig. 7).
Postos isoladamente ou agrupados, mas sem flutuadores (Fig. 7).

\section{LARVAS}

Não apresentam sifão respiratório; os espiráculos se abrem em placa situada na superfície do Seg.VIII (Figs. 8 e 10).

Posicionam-se paralelas à superfície líquida (Fig. 8).
Com sifão respiratório; os espiráculos se abrem na extremidade desse órgão (Figs. 8 e 9).

Posicionam-se em ângulo com a superfície líquida (Fig. 8). 


\section{PUPAS}

Trombeta curta, cônica e de abertura larga (Fig. 11).
Trombeta alongada, geralmente de forma cilíndrica e de abertura estreita (Fig. 11).

\section{SUBFAMÍLIA ANOPHELINAE}

Esta subfamília reúne três gêneros : Anopheles, cosmopolita; Chagasia, restrito à região neotropical e Bironella, existente apenas na região australiana.

Veja a seguir como identificar os adultos e fases imaturas dos gêneros Chagasia e Anopheles, que incluem espécies existentes no Brasil.

\section{CHAGASIA}

\section{ANOPHELES}

\section{ADULTOS}

Escutelo ligeiramente trilobado na Escutelo arredondado na margem margem posterior; posterior;

Pousam como os Culicinae, ou seja, Pousam obliquamente ao substrato; quase paralelamente ao substrato;

Mosquitos de aspecto hirsuto e amar- Mosquitos de aspecto não hirsuto, ronzado.

\section{LARVAS}

Cerdas palmadas (Cerda 1-II-VII) com Cerdas palmadas diferentes (Fig. 10). elementos em forma de raquete, com a margem distal serrulada e uma expansão filamentosa no topo (Fig. 10).

\section{PUPAS}

Cerda 5-III-VII espiniforme.

Cerda 5-III-VII normal.

\section{GENERO CHAGASIA CRUZ, 1906}

O gênero Chagasia compreende apenas quatro espécies, as quais podem ser identificadas empregando-se as chaves apresentadas por Forattini (1962). Assemelham-se às Mansonia no que diz respeito à coloração geral, à atitude de repouso e ao aspecto felpudo de que é provida a área supra-alar do escudo.

Biologia. São mosquitos essencialmente silvestres, associados à existência de pequenos córregos, especialmente àqueles que descem as encostas das montanhas. Suas larvas criam-se, protegidas da correnteza, entre as raízes e detritos vegetais existentes nas margens de riachos de fundo arenoso e águas límpidas. 
Os adultos são geralmente encontrados em áreas silvestres, preferindo picar junto à copa das árvores (Galindo et al. 1950; Deane et al., 1968; 1971; Ferreira-Neto et al., 1970) Não se conhece importância epidemiológica para as espécies de Chagasia, embora elas possam ser abundantes em dadas localidades (Barbosa et al., 1993).

\section{GENERO ANOPHELES MEIGEN, 1818}

O gênero Anopheles compreende, hoje, 54 espécies que ocorrem no Brasil, agrupadas em cinco subgêneros, conforme a seguir:

Chave para a identificação dos subgêneros de Anopheles, na fase adulta, que ocorrem no Brasil.

1. Tarsos posteriores III a V cobertos principalmente por escamas brancas (Fig. 16.a-g)

Tarsos posteriores III a $\mathrm{V}$ marcados diferentemente (Figs. 17.1, 18.j-o)

2. Escudo ornamentado por faixas dispostas longitudinalmente (Figs. 17.g e 18.r)

Escudo sem ornamentação em forma de faixa (Fig. 17.h) 4

3. Escudo com 4 faixas longitudinais escuras

(Fig. 17.g); algumas veias com manchas de escamas brancas, mas veia anal coberta apenas por escamas escuras

Escudo com uma faixa longitudinal mediana prateada (Fig. 18.r); todas as veias da asa com apenas escamas escuras. Stethomyia Theobald, 1902.

4. Fêmur posterior com tufo de escamas eretas (Fig. 17.p) Lophopodomyia Antunes, 1937(parte)

Fêmur posterior sem esse tufo (Fig. 17.n, o) Anopheles Meigen, 1818 Lophopodomyia (parte) 
Um sextò subgênero denominado Cellia, embora dotado de enorme importância epidemiológica, só ocorre no Velho Mundo. Uma das espécies deste subgênero - o An.gambiae Giles, 1902 - invadiu parte do nordeste brasileiro provavelmente em 1930 e lá esteve até 1940, causando, entre 1938 e 1939, uma das mais graves epidemias de malária registradas no país (Pinto, 1939). Trata-se de um mosquito africano, cujas fêmeas são altamente antropofílicas e endófilas. Suas larvas são normalmente encontradas em pequenas coleções de águas limpas no solo, rasas, pobres em vegetação e bastante expostas ao sol. As cacimbas, poços rasos feitos pelos nordestinos para obtenção de água, constituíram importantes focos desse mosquito durante sua permanência no Brasil (Soper \& Wilson, 1943; Deane, 1985; 1986).

Os mosquitos do gênero Anopheles que ocorrem no Brasil podem ser identificados empregando-se as chaves dicotômicas apresentadas a seguir, modificadas a partir das propostas por Gorhan et al.(1967) para os anofelinos sul-americanos. Contudo, há muito se tem verificado a ocorrência de indivíduos ou formas anômalas em espécies de Anopheles, os quais apresentam fenótipo diferente do usual (Faran, 1980; Harbach et al. 1993), podendo não ser propriamente identificados com o emprego dessas chaves dicotômicas.

Chave para a identificação de adultos das espécies de Anopheles que ocorrem no Brasil.

1. Pelo menos dois artículos tarsais posteriores

inteiramente brancos (Fig. 16.a-f).

Nenhum ou apenas um dos artículos tarsais

posteriores inteiramente brancos (Figs. 16.g e 17.j-1)

2. Tarsos posteriores com os três últimos artículos (III-V) inteiramente brancos (Fig. 16.b, c)

Tarsos posteriores III e IV inteiramente brancos $e$ tarso V com anel negro basal (Fig.16.a).

3. Primeira mancha escura da veia costa (pré-umeral escura) maior que a mancha clara seguinte (umeral clara) (Fig. 16.h)

Primeira mancha escura da veia costa menor que a mancha clara seguinte (Fig.16.i)

4. Veia Anal predominantemente clara, com uma mancha negra perto de cada extremidade (Fig. 16.h); tergitos abdominais com escamas amareladas. darlingi 

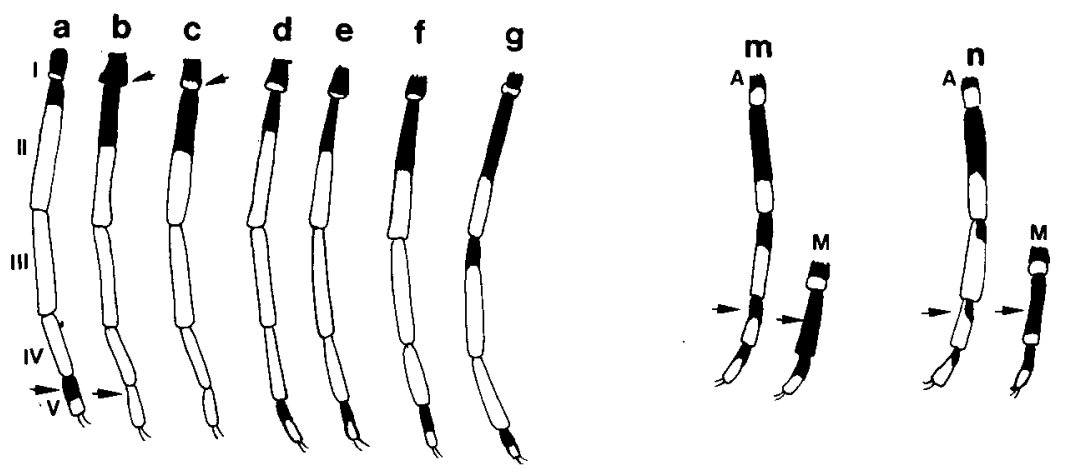

h
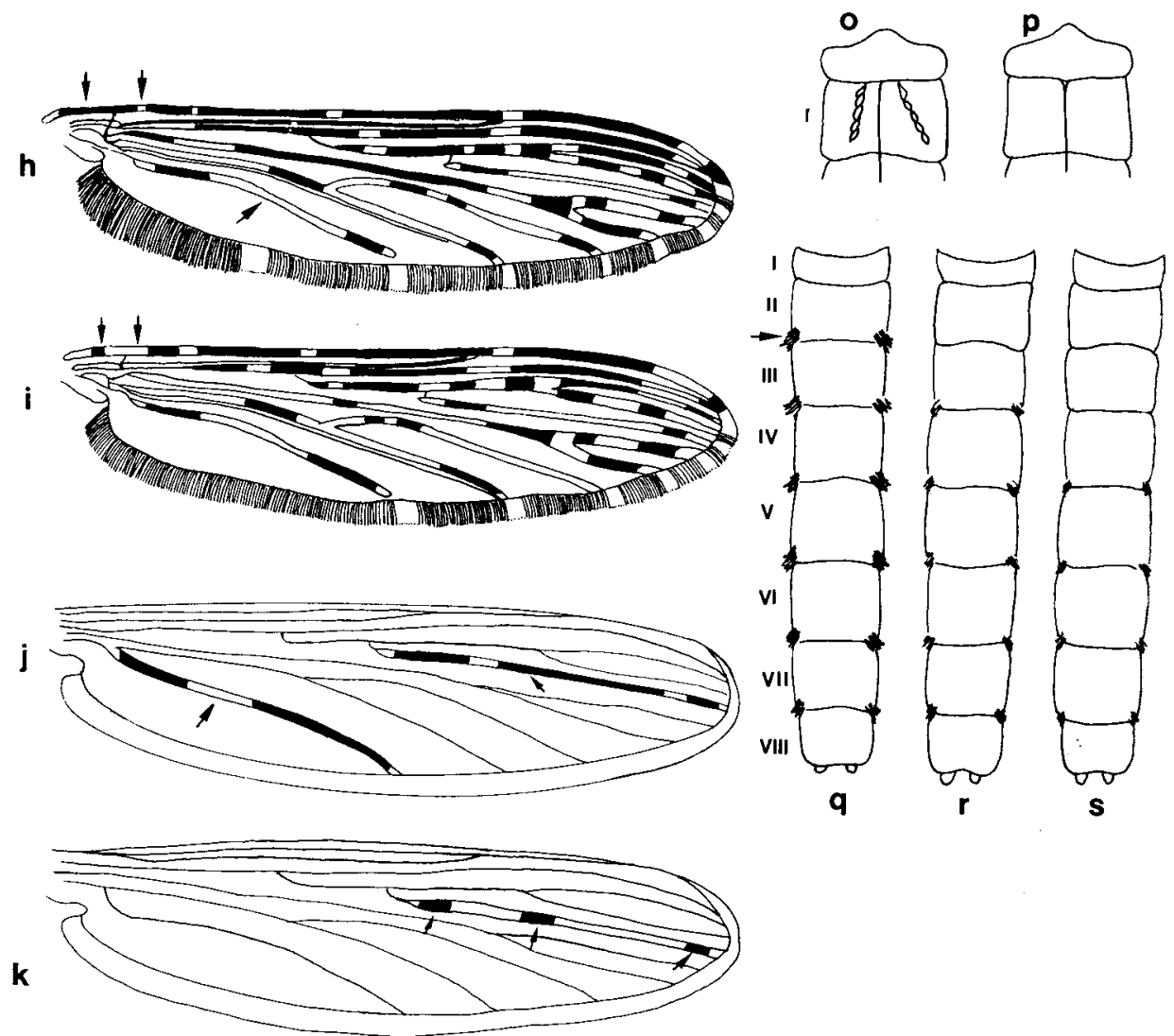

q

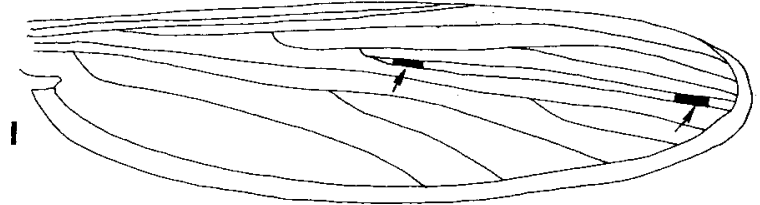


Veia Anal predominantemente escura (Fig. 16.j);

tergitos abdominais sem escamas.

5. Veia $\mathrm{R}_{4+5}$ predominantemente negra (Fig. 16.j) ........................................ lutzi

Veia $R_{4+5}$ predominantemente branca (Fig. 16.k,l) ....................................... 6

6. Veia $R_{4+5}$ com três manchas negras (Fig.16.k) ......................................... parous

Veia $R_{4+5}$ com duas manchas brancas (Fig. 16.1) ................................. antunesi

7. Tarso posterior I com anel claro apical (Fig. 16.c) ............................................ 8

Tarso posterior I sem anel claro apical (Fig. 16.b) ........ argyritarsis argyritarsis .e argyritarsis sawyeri

8. Esternito abdominal I com duas linhas de escamas

brancas (Fig. 16.0) 9

Esternito abdominal I sem linhas de escamas

(Fig. 16.p). lanei

9. Tergito abdominal II sem tufos póstero-laterais de escamas escuras (Fig. 16.r, s); Tergito VIII com escamas amareladas e brancas 10

Tergito abdominal II com tufos póstero-laterais de escamas escuras; Tergito VIII densamente coberto por escamas alvas (Fig. 16.q) braziliensis

10. Tergitos abdominais com tufos póstero-laterais de escamas escuras a partir do segmento III (Fig. 16.r); manchas claras das veias anteriores da asa, particularmente da costa, formadas por escamas quase tão alvas quanto as dos tarsos posteriores III-V. albitarsis

Tergitos abdominais com tufos póstero-laterais de escamas escuras a partir do segmento IV (Fig. 16.s); manchas claras das veias, particularmente da costa, formadas por escamas amareladas em comparação com as dos tarsos posteriores III-V

deaneorum

1 FIG. 16: Aspectos da morfologia externa de Anophelinae adultos. Ilustrações referidas na

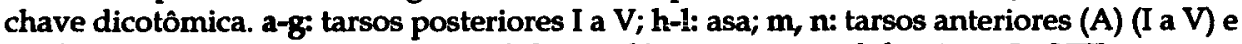
médios (M) (III a V); o, p: esternito abdominal I; q-s: tergitos abdominais I a VIII. 
11. Primeira mancha escura da costa (pré-umeral escura) maior ou igual a mancha clara seguinte (umeral clara) (Fig. 17.a, b) (ou um pouco menor em certas fêmeas de nuneztovari e dunhami).

Primeira mancha escura da costa menor que a mancha clara seguinte (Fig. 17.d)

12. Mancha Sc (subcostal clara) pequena, rudimentar ou ausente (Fig. 17.a); mesanepímero com um grupo de escamas claras anteriormente; escamas claras da asa muito alvas, como as dos tarsos posteriores III,IV triannulatus triannulatus e triannulatus davisi

Mancha Sc (subcostal clara) de tamanho médio (Fig. 17.b); mesanepímero sem grupo de escamas claras. nuneztovari e dunhami

13. Tarso posterior II com 8 a $20 \%$ de negro na base (Fig. 16.a).

Tarso posterior II com mais de $20 \%$ de negro na base (Fig. 16.df)

14. Tarso anterior IV com mais de $30 \%$ basal escuro; tarso mediano IV totalmente escuro (Fig. 16.m) oswaldoi

Tarso anterior IV com menos de $30 \%$ basal escuro; tarso mediano IV com uma mancha clara apical (Fig. 16.n) ininii

15. Mancha SC (subcostal clara) medindo mais da metade da mancha escura precedente (setorial escura) (Fig. 17.e) rangeli

Mancha SC (subcostal clara) medindo menos da metade da mancha setorial escura (Fig. 17.b, d)

As escamas claras da Veia Costa são amareladas ou nitidamente amareladas ou cremes em $A n$. nuneztovari, enquanto são esbranquiçadas ou distintamente brancas em An. dunhami. A primeira espécie é muito espalhada na Amazónia, ao passo que a segunda só foi detectada, no Brasil, em Tefé, Amazonas (Peyton, 1993). 
16. Porção não bifurcada da veia Média (M)

predominantemente clara (Fig. 17.d)

Porção não bifurcada da vẹia Média (M) predominantemente escura, pelo menos na superfície ventral (Fig. 17.c)

benarrochi

17. Tarso posterior II com mais de $40 \%$ ( 40 a $55 \%$ ) de negro na porção basal (Fig. 16.f) aquasalis e galvaoi

Tarso posterior II com até $40 \%$ de negro basal (Fig.16.d, e).
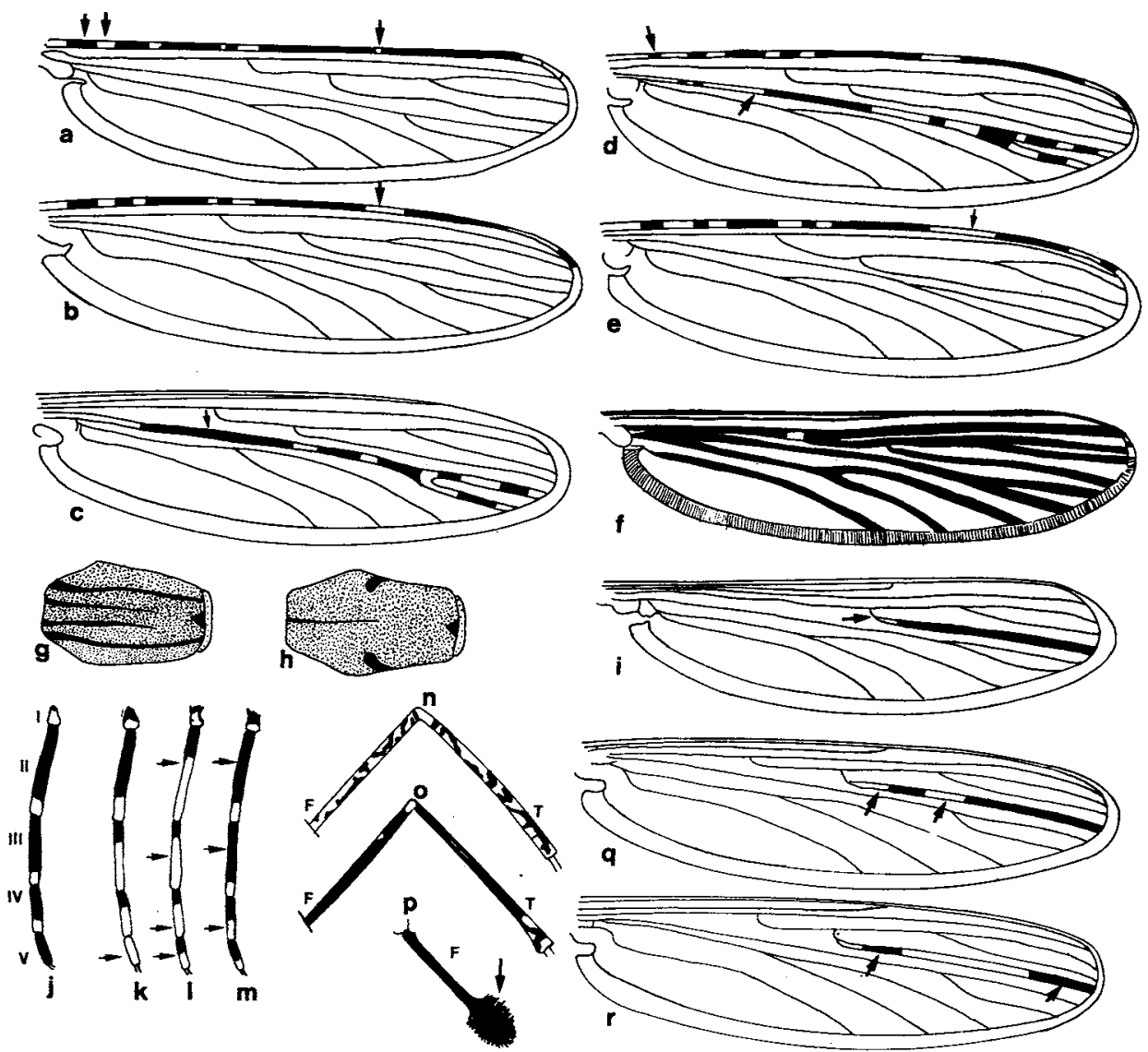

FIG. 17: Aspectos da morfologia externa de Anophelinae adultos. Ilustrações referidas na chave dicotômica. a-f, i, q, r: asa; $g$, h: escudo e escutelo; $j$-l: tarsos posteriores I a V; $n$, o: fềmur e tíbia posteriores; $p$ : fêmur posterior. 
18. Tarso posterior II com geralmente entre 20 e $30 \%$, ou pouco mais, de negro basal (Fig. 16.d); escamas das mancha das veias anteriores da asa amareladas evansae

Tarso posterior II com geralmente mais de 35\% negro basal (Fig. 16.e); escamas das manchas claras das veias anteriores da asa, particularmente da costa, bem alvas, tal como as que revestem os tarsos posteriores III e IV

19. Asa com muitas manchas de escamas claras intercaladas por manchas escuras (Fig. 16.h) …….......................................... 20

Asa quase totalmente escura (Fig. 17.f) ............................................................ 34

20. Tarso posterior IV inteiramente branco (Fig. 16.g) rondoni Tarso posterior IV não inteiramente branco (Fig. 17.j-1) 21

21. Escudo com quatro faixas longitudinais escuras (Fig. 17.g) 22

Escudo sem quatro faixas escuras (Fig. 17.h) 27

22. Tarso posterior $\mathrm{V}$ inteiramente negro (Fig. 17.j) bellator Tarso posterior $\mathrm{V}$ parcial ou completamente branco (Fig. 17.k-m)

23. Tarso posterior $\mathrm{V}$ inteiramente branco (Fig. 17.k) bambusicolus Tarso posterior $\mathrm{V}$ parcialmente branco (Fig. 17.1) 24

24. Veia $R 4+5$ com apenas uma mancha branca (Fig. 17.i). neivai

Veia $\mathbf{R}_{\mathbf{4}+5}$ com mais de uma mancha branca (Fig. 17.q, r).

25. Tarsos posteriores II a IV com menos de $35 \%$ de negro na porção basal (Fig. 17.l) laneanus Tarsos posteriores II a IV com pelo menos $50 \%$ de negro (Fig. 17.m) 
26. Veia $R 4+5$ predominantemente escura, com duas manchas brancas basais (Fig. 17.q) homunculus

Veia $R 4+5$ predominantemente branca, com uma mancha negra basal e outra apical (Fig. 17.r). cruzii

27. Patas sem aspecto de salpicado (Fig. 17.0) 28

Patas com aspecto de salpicado (Fig. 17.n)

28. Fêmur posterior com tufo apical de escamas escuras (Fig. 17.p). squamifemur

Fêmur posterior sem tufo de escamas (Fig. 17.o) 29

29. Tarso posterior $V$ inteiramente branco (Fig.18.a) nigritarsis Tarso posterior $V$ escuro (Fig. 18.b) 30

30. Tíbia posterior com grande mancha branca apical

(Fig. 18.c)

Tíbia posterior sem a mancha branca apical

(Fig. 18.d)

31. Veia Anal escura (Fig. 18.g) tibiamaculatus

Veia Anal com manchas brancas (Fig. 18.h, i) 32

32. Veia Anal com 5 ou 6 manchas negras (Fig. 18.h) pseudotibiamaculatus Veia Anal com 2 ou 3 manchas negras (Fig. 18.i) gilesi

33. Tergito abdominal VIII densamente coberto por escamas brancas (Fig. 18.e) peryassui

Tergito abdominal VIII sem escamas brancas (Fig. 18.f) mattogrossensis

34. Tíbia posterior com faixa clara apical (Fig. 18.c); escudo sem faixa prateada longitudinal eiseni Tíbia posterior sem a faixa apical (Fig. 18.d); escudo com faixa prateada longitudinal mediana (Fig. 18.r, s) 
35. Cada margem lateral do escudo com uma faixa prateada tão nítida quanto a faixa mediana

(Fig. 18.r); cerdas claras do vértice longas, ultrapassando a base das antenas.

nimbus e thomasi

Faixas prateadas marginais do escudo muito menos nítidas que a faixa mediana (Fig. 18.s); cerdas do vértice normais
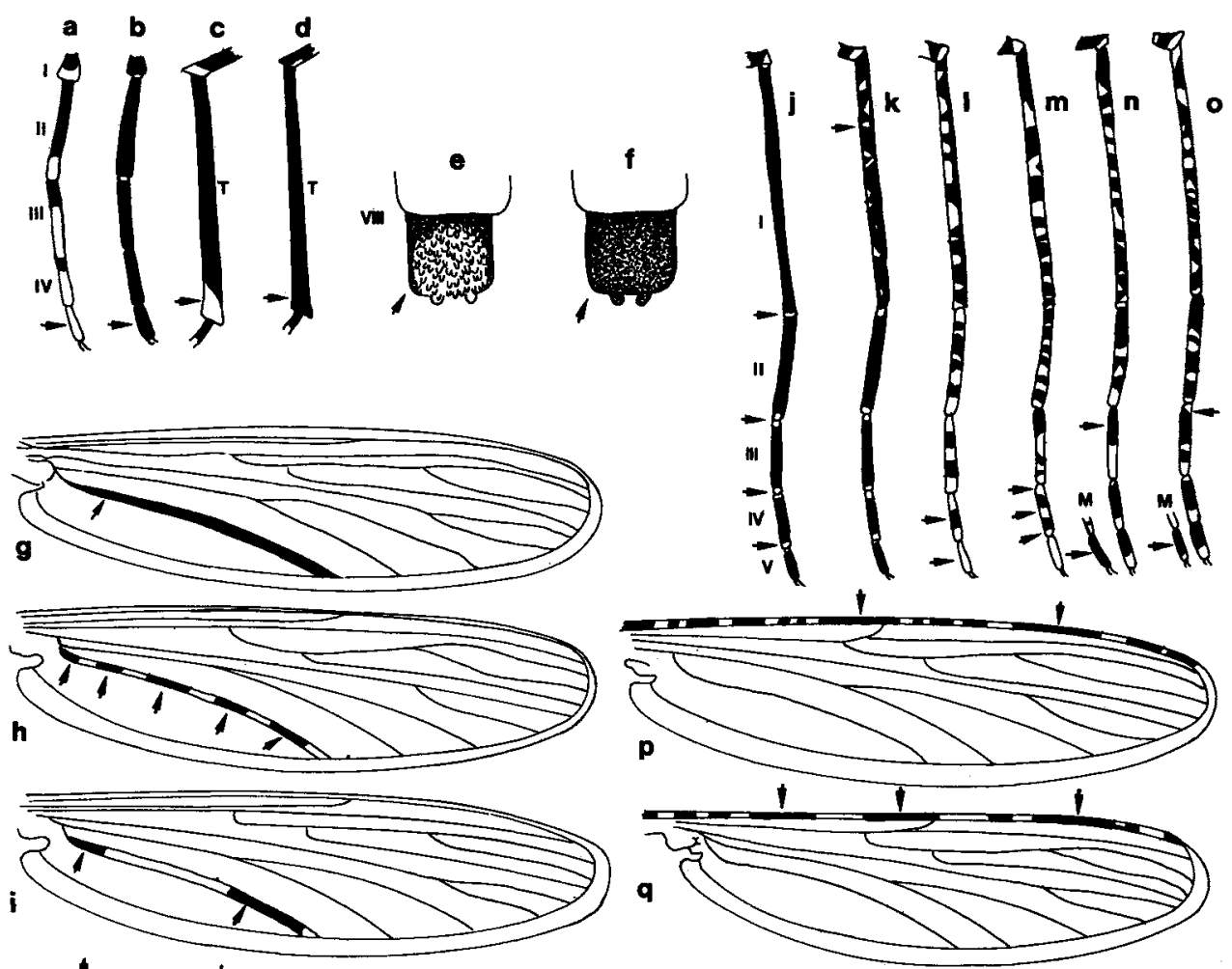

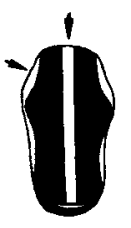

$\boldsymbol{r}$

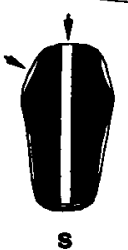

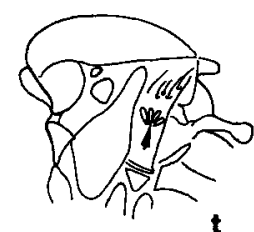

$\mathbf{t}$
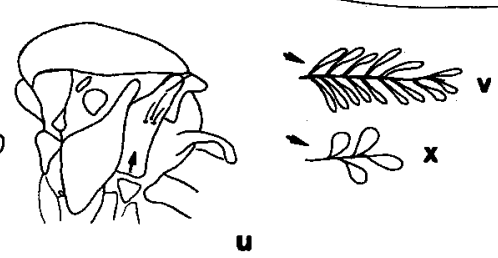

FIG. 18: Aspectos da morfologia externa de Anophelinae adultos. Ilustrações referidas na chave dicotômica. a, b: tarsos posteriores I a V; c, d: tíbia posterior (T); e, f: tergito abdominal VIII; g-i, p, q: asa; j-m: tarsos posteriores I a V; $\mathbf{n}$, o: tarsos posteriores (I a V) e médio (M) (V); $r$, s: escudo e escutelo, vista dorsal; $t$, $u$ : tóray, vista lateral; $v, x$ : escamas das veias anteriores da asa. 
36. Tarsos posteriores II a IV negros, com anéis brancos apenas nas articulações (Fig. 18.j, k)

Tarsos posteriores II a IV com mais áreas claras

(Fig. 18.1-o)

37. Mosquito grande; tarso posterior I escuro, com um

estreito anel branco apical (Fig. 18.j) shannoni

Mosquito pequeno; tarso posterior I com muitas manchas claras pequenas (Fig. 18.k) minor

38. Tarso posterior $\mathrm{V}$ inteiramente claro (Fig. 18.1, $\mathrm{m}$ )........................................... 39

Tarso posterior $V$ com parte escura (Fig. $n, o$ ). 41

39. Tarso posterior IV claro, com geralmente uma faixa escura (ou duas) mais ou menos mediana (Fig. 18.1) mediopunctatus

Tarso posterior IV escuro, com 3 manchas claras (Fig. 18.m)

40. Mesanepímero com um grupo de escamas brancas (Fig.. 18.t). fluminensis Mesanepímero sem grupo de escamas brancas (Fig. 18.u.). punctimacula

41. Escamas da porção basal da asa estreitas (Fig. 18.v) 42

Escamas da porção basal da asa muito largas (Fig. 18.x).

42. Veia Costa com duas grandes manchas negras (Fig. 18.p). neomaculipalpus

Veia Costa com três grandes manchas negras (Fig. 18.q).

43. Tarso posterior III com anel negro basal; tarso médio $\mathrm{V}$ inteiramente escuro (Fig. 18.n) anchietai Tarso posterior III com área branca basal; tarso médio V com ápice claro (Fig. 18.0) maculipes 
44. Porção não bifurcada da veia $\mathrm{Cu}$ predominantemente escura (Fig. 19.a)

Porção não bifurcada da veia $\mathrm{Cu}$ predominantemente clara (Fig. 19.c)

45. Metade apical da veia Anal negra (Fig. 19.a) bustamantei Metade apical da veia Anal com áreas claras e escuras intercaladas (Fig. 19.b) intermedius

46. Veia Anal com 3 ou 4 manchas negras (Fig. 19.c) rachoui Veia Anal com 6 ou 7 manchas negras (Fig. 19.d) evandroi $\mathrm{e}$ punctimacula

Os anofelinos pertencentes ao subgênero Nyssorhynchus encontram-se nos itens de 4 a 20 e 29 da chave dicotômica para adultos apresentada acima, enquanto as demais espécies assim se distribuem: itens 22 a 26 - Subgênero Kerteszi; itens 28 e 32 - subgênero Lophopodomyia; item 35 - subgênero Stethomyia e os demais itens correspondem às espécies do subgênero Anopheles.

Com respeito às formas imaturas, apresentamos a seguir uma chave para identificação das larvas de quarto estágio. No caso de se obter pupa na natureza, aconselhamos deixar emergir o adulto e então identificá-lo empregando a chave correspondente.

\section{Chave para a identificação de larvas das espécies de Anopheles que ocorrem no Brasil.}

1. Tufos palmados abdominais (cerdas 1-I-VII)

constituídos por elementos filiformes (Fig. 19.e)

Tufos palmados abdominais constituídos por

elementos largos, isto é, foliáceos (Fig. 19.f)

2. Cerda 1-P com seis ramos ou mais (Fig. 19.h,i)

Cerda 1-P, em forquilha, com apenas 2 ou 3 ramos apicais (Fig.19.g) thomasi

3. Cerda 1-P com 6 a 8 ramos (Fig. 19.h) kompi Cerda 1-P com 11 a 14 ramos (Fig. 19.i) nimbus 
4. Cerdas 5 a 7-C lisas ou muito levemente aciculadas

(Fig. 19.1); larvas coletadas em plantas, essencialmente bromélias.

Cerdas 5 a 7-C aciculadas, como uma palma

(Fig. 19.m); larvas não procedentes de plantas
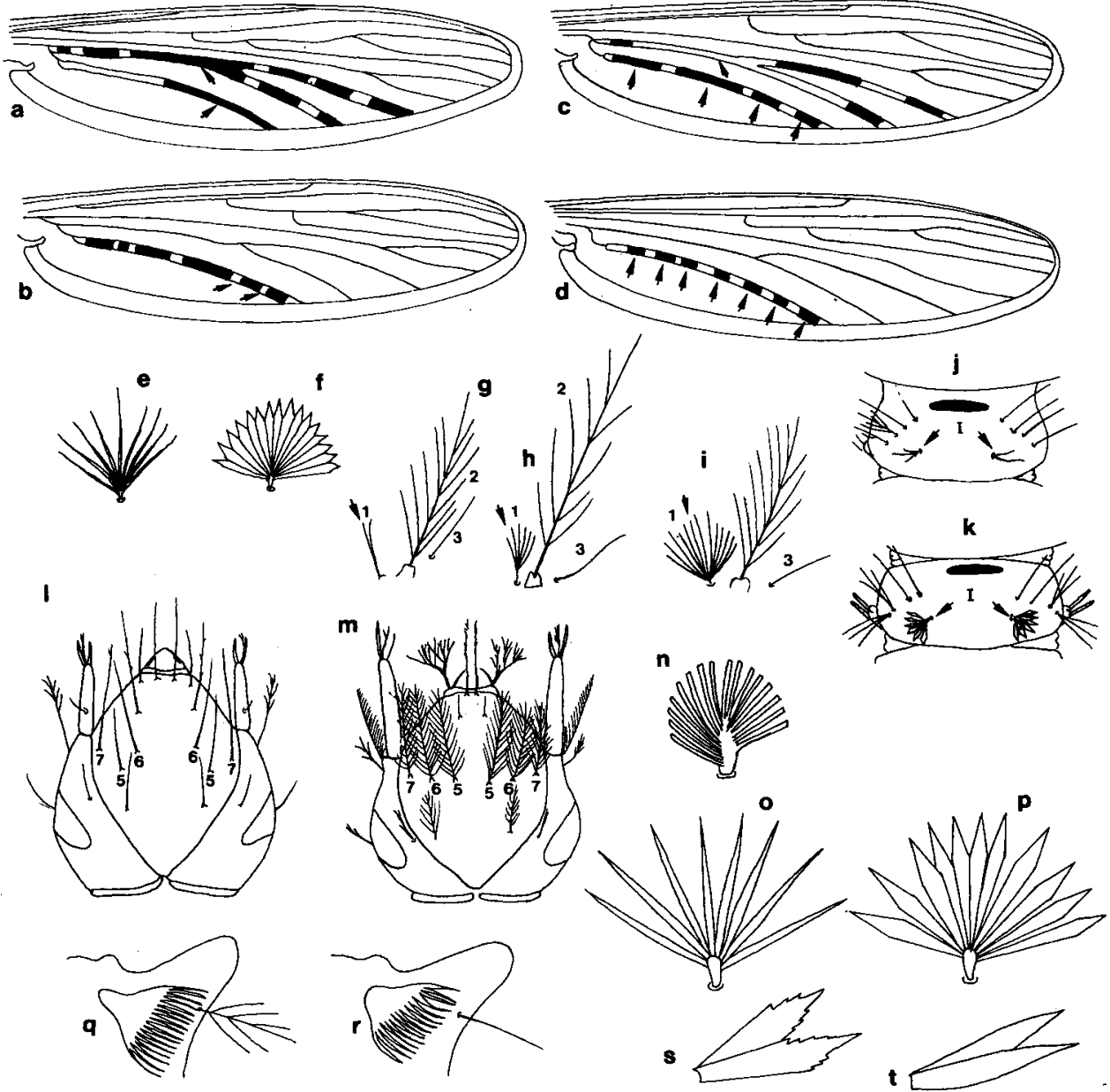

Fic. 19: Aspectos da morfologia externa de Anophelinae adulto e larva. Ilustraçōes referidas nas chaves dicotômicas correspondentes. a-d: asa; e, f: tufo palmado; g-i: conjunto das cerdas protorácicas 1-3-P; $\mathbf{j}$, k: segmento abdominal I, vista dorsal; l, m: cabeça, vista dorsal; n-p: tufo palmado; $q$, r: pecten e cerda 1-S, em vista lateral do aparato espiracular; 8 , t: elementos de tufo palmado. 
5. Tufos palmados ausentes no primeiro segmento abdominal (Fig. 19.j); elementos que constituem os tufos com ápice truncado (Fig. 19.n). neivai

Tufos palmados presentes no primeiro segmento abdominal (Fig. 19.k); elementos que constituem os tufos palmados com ápice pontudo (Fig. 19.f)

6. Tufos palmados pequenos, com elementos estreitos e pontiagudos (Fig. 19.0)

Tufos palmados grandes, com elementos lanceolados (Fig. 19.p) bambusicolus

7. Cerda 1-S ramificada (Fig. 19.q) bellator Cerda 1-S simples (Fig. 19.r) (ou levemente aciculada em laneanus)

8. Tufos palmados com elementos lisos (Fig. 19.t)............................................... 9 Tufos palmados com elementos denteados (Fig. 19.s) ................................... 27

9. Cerda 6 dos segmentos abdominais IV e $\mathrm{V}$ simples (Fig. 20.a) 10

Cerda 6 dos segmentos abdominais IV e V ramificada (Fig. 20.b)

10. Cerdas 2-C muito aproximadas (espaço entre elas muito pequeno) (Fig. 20.c)

Cerdas 2-C bem separadas (espaço entre elas

ligeiramente menor que o existente entre $2-\mathrm{C} \mathrm{e} \mathrm{3-C)}$

(Fig. 20.d)

11. Cerda 1-P com ramos lanceolados (Fig. 20.e) 13

Cerda 1-P com ramos filiformes (Fig. 20.f)

12. Elementos dos tufos palmados abdominais com ápice filamentoso (Fig. 20.k) argyritarsis sawyeri Elementos dos tufos palmados abdominais mais curtos e com ápice não filamentoso (Fig. 20.l) argyritarsis argyritarsis 

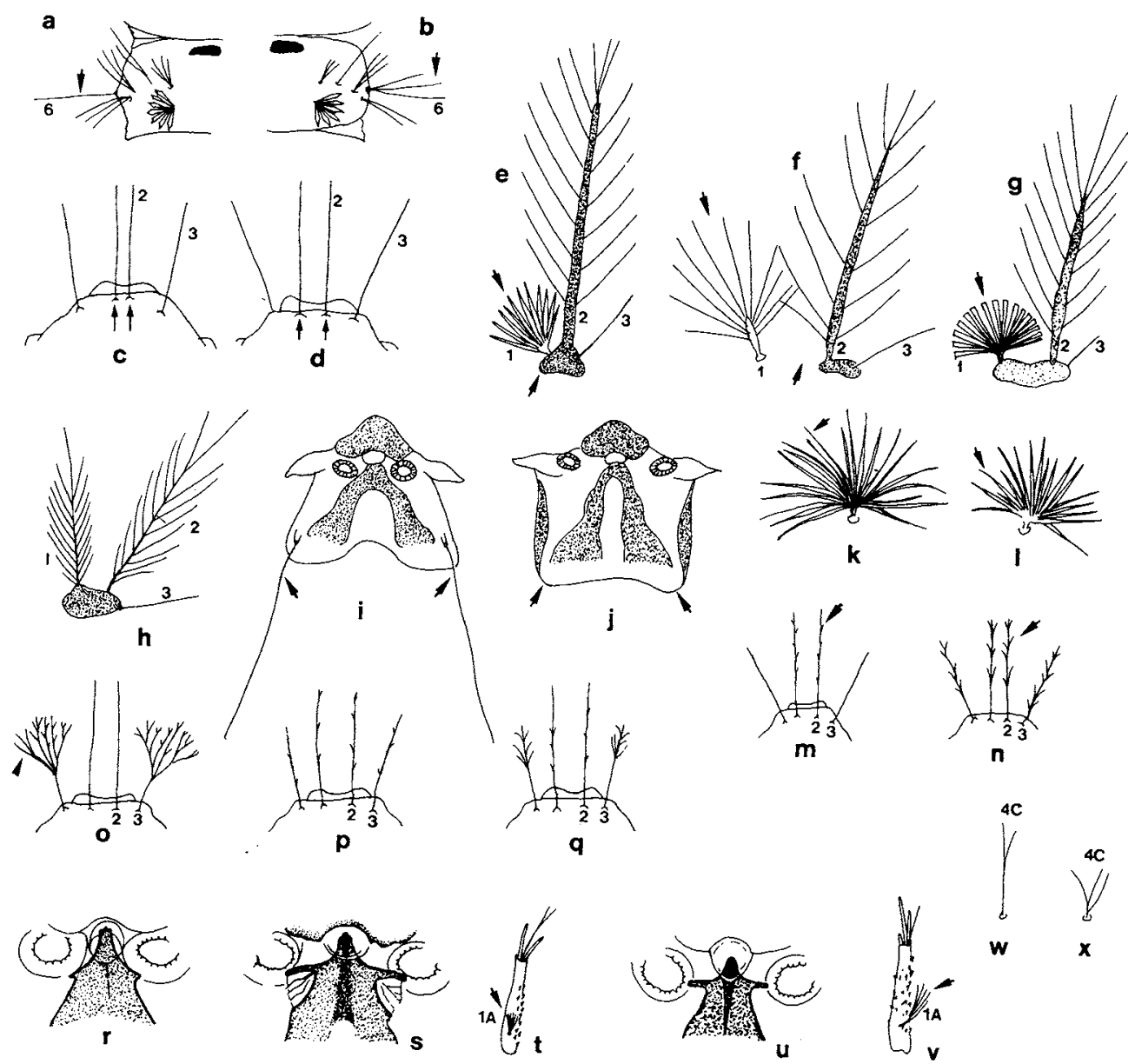

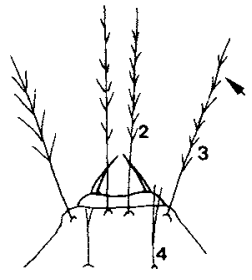

$\mathbf{y}$

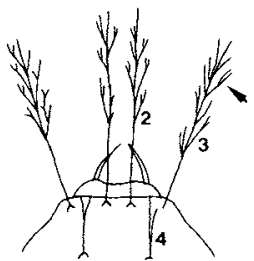

$\mathbf{z}$

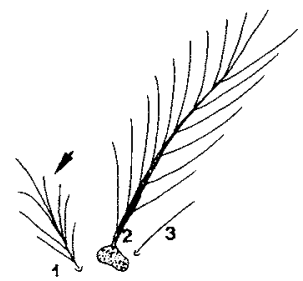

$\propto$

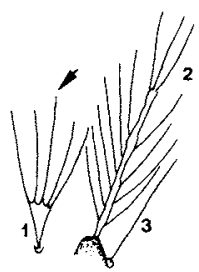

B

Fig. 20: Aspectos da morfologia externa de Anophelinae larva. Ilustrações referidas na chave dicotômica. a, b: segmento abdominal $V$, vista dorsal; $\mathbf{c}, \mathbf{d}, \mathbf{m}-\mathbf{q}, \mathbf{y}, \mathbf{z}$ : cabeça, vista dorsal da porção anterior; e-h, $\alpha, \beta$ : conjunto de cerdas protorácicas 1-3-P; i, i, r, s, u: aparato espiracular, vista dorsal; $k$, l: tufo palmado; $t$, v: antena; $x$, w: cerda 4-C (cabeça). 
13. Cerda 1-P e os tufos palmados abdominais com ramos ponteagudos (Fig. 20.e, 1) strodei e rondoni

Cerda 1-P e os tufos palmados abdominais com ramos de ponta romba (Figs. 19.n e 20.g) braziliensis

14. Cerda 1-P com ramos filamentosos que se originam em diferentes alturas da haste (Fig. 20.h)

Cerda 1-P com aspecto palmado, com ramos finos ou largos, mas que se originam de um mesmo nível (Fig. 20.e, $\mathrm{f}$ )

15. Lobos posteriores da placa espiracular com cerda longa implantada em tubérculo (Fig. 20.i); cerda 3-C não ramificada (Fig. 20.p) darlingi

Lobos posteriores da placa espiracular sem cerda longa (Fig. 20.j); cerda 3-C com muitos ramos (aspecto dendrítico) (Fig. 20.o) lanei

16. Cerda 1-P com ramos lanceolados (Fig. 20.e, l). 17 Cerda 1-P com ramos filiformes (Fig. 20.f). triannulatus triannulatus

17. Cerdas 1, 2 e 3-P se originam em uma mesma placa bem quitinizada (Fig. 20.e). 18

Cerda 1-P não se origina em uma placa quitinizada comum com a 2 e 3-P (Fig. 20.f)

18. Cerda 3-C levemente aciculada (Fig. 20.p). albitarsis Cerda 3-C com ramificações alongadas (Fig. 20.q) deaneorum

19. Cerdas 2 e 3-C levemente aciculadas (Fig. 20.m) ............................................. 20

Cerdas 2 e 3-C distintamente ramificadas (Fig. 20.n) 23

20. Placa mediana do aparato espiracular com expansões laterais curtas ou rudimentares (Fig. 20.r)

Placa mediana do aparato espiracular com expansões laterais distintas, como braços (Fig. 20.s, u) 
21. Placa espiracular com "braços" muito longos

(Fig. 20.s); cerda 1-A curta, menor que o dobro da

largura da base da antena (Fig. 20.t) triannulatus davisi

Placa espiracular com "braços" alongados

(Fig. 20.u); cerda 1-A longa, maior que o dobro da

largura da base da antena (Fig. 20.v). ininii

22. Cerda 4-C simples ou em forquilha, com 2 ou 3

ramos apicais (Fig. 20.x) nuneztovari e dunhami Cerda 4-C ramificada ao nível da base (Fig. 20.w.).... evansae, galvaoi e rangeli

23. Cerda 1-A longa (Fig. 20.v) benarrochi

Cerda 1-A pequena, muitas vezes pouco visível (Fig. 20.t). 24

24. Cerdas 2 e 3 -C com ramificações dicotômicas

(Fig. 20.z); placa espiracular com expansões alongadas (Fig. 20.u) oswaldoi

Cerdas 2 e 3-C com ramificações simples (Fig. 20.y); placa espiracular com expansões rudimentares (Fig. 20.r) aquasalis

25. Tufos palmados abdominais rudimentares (Fig. 19.j) lutzi Tufos palmados abdominais normais (Fig. 19.k) 26

26. Ramos da cerda 1-P se originam de vários níveis da haste (Fig. 20. $\alpha$ ) parous

Ramos da cerda 1-P se originam quase no mesmo nível da haste (Fig. 20. $\beta$ ). antunesi

27. Cerdas 2 e 3-A ponteagudas (Fig. 21.b) 34 Uma das cerdas 2 e 3-A com ápice truncado (Fig. 21.a, c)

As diferenças entre essas especies parecem ser: em nuneztovari as cerdas 2, 3-C são nitidamente aciculadas a partir da metade distal (especialmente em 3-C) e cerda $4-C$ é geralmente 0,3-0,6 o comprimento de 3-C; em dunhani, 2, 3-C são lisas ou ligeiramente aciculadas e 4-C é 0,7-1,0 do comprimento de 3-C (Peyton, 1993). 
28. Cerda 3-C simples ou bifurcada (Fig. .20.m) neomaculipalpus

Cerda 3-C com muitos ramos, de aspecto dendrítico

(Fig.20.0)

29. Ramos da cerda 1-P originando-se de diferentes

níveis da haste (Fig. 20. . ).

Ramos da cerda 1-P originando-se do mesmo nível, como um tufo palmado (Fig. 20.e, l). mattogrossensis

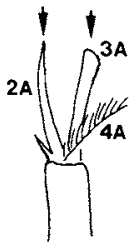

a

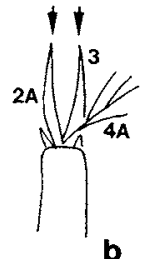

b

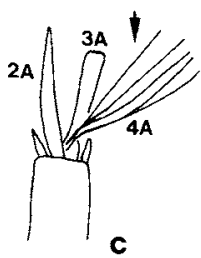

c
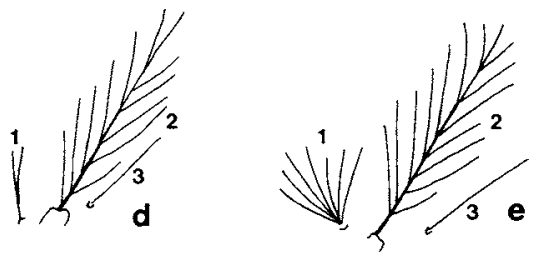

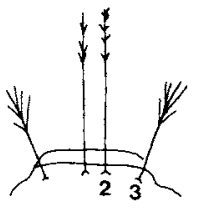

f

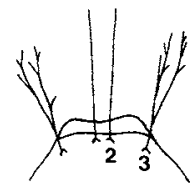

g
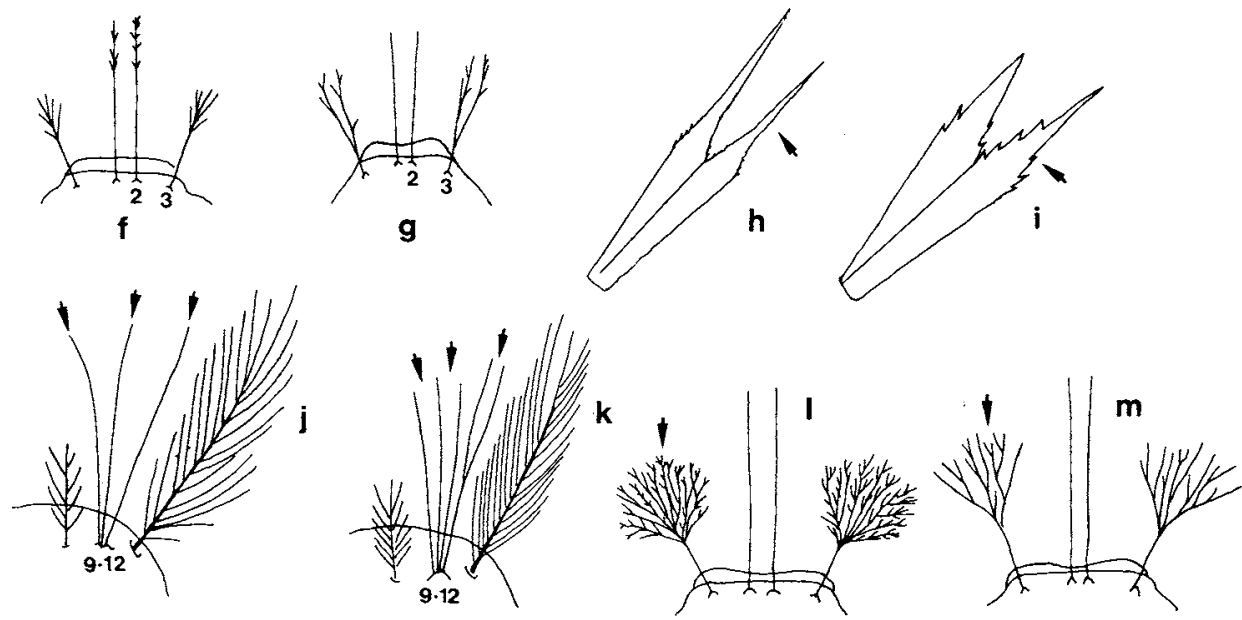

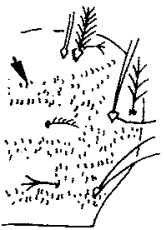

$\mathbf{n}$

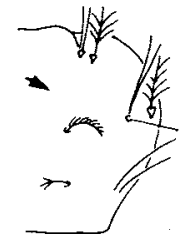

o

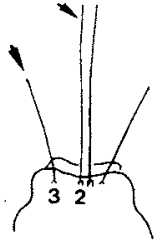

p

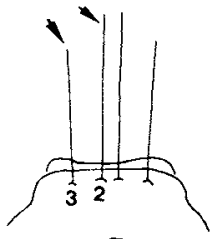

q

Fig. 21: Aspectos da morfologia externa de Anophelinae larva. Ilustrações referidas na chave dicotômica. a-c: antena, ápice; $d$, e: conjunto de cerdas protorácicas 1-3-P; f, g, l, m, p, q: cabeça, vista dorsal da porção anterior; $j$, k: conjunto de cerdas protorácicas 9-12-P; n, o: tórax, aspecto do tegumento ventral. 
30. Todas as cerdas do grupo lateral 9, 10 e 12-P simples

(Fig. 21.j)

Pelo menos uma das cerdas do grupo 9, 10 e 12-P

ramificada (Fig. 21.k).

31. Cerda 4-A curta, com muitos ramos curtos, quase todos originados no mesmo lado da cerda (aspecto pectinado) (Fig. 21.a) mediopunctatus

Cerda 4-A longa, com 4 a 8 ramos que se originam quase do mesmo nível (Fig. 21.c) punctimacula

32. Cerda 1-P simples ou com no máximo 2 ou 3 ramos (Fig. 21.d)

Cerda 1-P múltipla, com mais de 4 ramos (Fig. 21.e) fluminensis

33. Cerda 3-C ramificada na metade distal (aspecto de pincel) (Fig. 21.f) maculipes e anchietai

Cerda 3-C ramificada desde a metade basal (Fig. 21.g). intermedius

34. Ramos dos tufos palmados abdominais sem filamento apical (Fig. 21.i)

Ramos dos tufos palmados abdominais terminando num longo filamento (Fig. 21.h); cerdas 2-C muito aproximadas (Fig. 20.c); cerda 1-P na forma de um tufo palmado gilesi

35. Todas as cerdas do grupo 9, 10 e 12-P simples

(Fig. 21.j)

Pelo menos uma das cerdas do grupo 9, 10 e 12-P

bifurcada ou ramificada (Fig. 21.k) pseudotibiamaculatus

36. Cerda 3-C bem ramificada (aspecto dendrítico)

(Fig. 21.1, m)

Cerda 3-C simples ou bifurcada (Fig. 20.m, p) 40

37. Cerda 1-P na forma de um tufo palmado (Fig. 20.e, f) mattogrossensis Cerda 1-P com ramos originando-se de vários níveis, sem aspecto de tufo palmado (Fig. 20.h, $\alpha$ ). 
38. Cerda 3-C com mais de 30 ramificações (Fig. 21.1) 39

Cerda 3-C com menos de 20 ramos (Fig. 21.m) shannoni

39. Superfície ventral do tórax e abdome espiculosa

(Fig. 21.n) minor

Superfície do tórax e abdome glabra (Fig. 21.o.)

peryassui

40. Cerda 3-C muito menor que 2-C (Fig. 21.p) eiseni

Cerda 3-C ligeiramente mais curta que $2-\mathrm{C}$

(Fig. .21.q)

tibiamaculatus

Uma descrição mais detalhada das características morfológicas da maioria das espécies de Anopheles que ocorrem em território brasileiro pode ser consultada nas publicações de Forattini (1962) e Faran(1980). Assim, não daremos detalhes morfológicos para cada espécie, já que suas características principais acham-se na chave dicotômica.

\section{ANOFELINOS RELACIONADOS COM A TRANSMISSÃO DE DOENÇAS}

Os transmissores da malária humana no Brasil estão incluídos nos subgêneros Nyssorhynchus e Kerteszia. Por isso, daremos atenção especial somente para algumas espécies desses dois grupos.

Até o final da década de 1970, todas as infecções maláricas em mosquitos eram detectadas através da técnica da dissecção individual dos anofelinos coletados numa área endêmica, examinando-se suas glândulas salivares e o estômago em preparações a fresco. Devido à falta de diferenças consistentes entre as formas evolutivas dos plasmódios, humanos e de animais, nos mosquitos, a espécie de parasito não podia ser identificada por essa técnica. Na década de 1980 foi descoberta uma técnica imunológica (radioinunometria = IRMA) capaz de identificar a espécie do esporozoíto que está infectando um mosquito (item "Radioimunoensaio (IRMA)", p.(175)). Esta faculdade, propiciada pelo uso de anticorpos monoclonais específicos contra a proteína que reveste o esporozoíto (proteína CS), foi mais tarde empregada em teste ELISA. Por essas duas técnicas, os mosquitos coletados numa área endêmica remota podem ser mortos e desidratados no campo, e testados meses depois, vários de uma só vez, em um laboratório distante. Porém, como a proteína CS já está presente no oocisto maduro, se um mosquito, cujo corpo todo foi incluído num imunensaio, apresenta resultado positivo, não significa que seja um bom vetor. Sabe-se que muitos mosquitos, inclusive alguns culicíneos, são capazes de permitir o desenvolvimento e maturação de oocistos de plasmódios de primatas, mas os esporozoítos viáveis não invadem ou se albergam nas suas glândulas salivares. Além disso, 
sabe-se da possibilidade de aparecerem resultados faso-positivos nesses imunensaios (ver item "Técnicas imunológicas para a detecção de infecção plasmodial em anofelinos", p.(174)).

Antes do emprego dessas técnicas, poucas espécies brasileiras de Nyssorhynchus haviam sido encontradas naturalmente infectadas com esporozortos, o que era utilizado para lhes atribuir o papel de vetor. Dentre estas estão, essencialmente, An. darlingi, An. aquasalis e An. albitarsis. Além delas, reconhecia-se também o papel de transmissores de paludismo dos anofelinos do subgênero Kerteszia: An. cruzii, An. bellator e An. homunculus.

Vários outros anofelinos do subgênero Nyssorhynchus são hoje considerados capazes de transmitir malária humana na natureza, mas (ver abaixo) geralmente figurando como vetores secundários, especialmente quando coexistem com o An. darlingi. São anofelinos principalmente exófilos, zoofílicos e crepusculares, mas que na ausência dos seus hospedeiros preferenciais ou nas épocas de elevada densidade, podem se alimentar no homem com dada freqüência. Neste caso, tais anofelinos podem, eventualmente, se infectar ao sugar portadores de gametócitos de plasmódios em áreas cuja endemicidade fora desencadeada e mantida às custas do An. darlingi.

São considerados vetores secundários ou vetores potenciais por terem sido achados naturalmente infectados em alguma área endêmica de paludismo, particularmente na Amazônia, as espécies que se seguem: An. deaneorum, An. braziliensis, An. nuneztovari, An. oswaldoi, An. triannulatus, An. strodei, An. evansae e An. galvaoi.

Além de possuírem hábitos hematofágicos que não lhes permitem freqüente contacto com o homem, as espécies de Anopheles supracitadas são geralmente pouco suscetíveis aos $P$. vivax e $P$. falciparum, com exceção de $A n$. deaneorum e An. nuneztovari (Deane et al., 1948; Klein et al., 1991a, b).

\section{Subgênero Nyssorhynchus Blanchard, 1902}

São anofelinos de pequeno e médio porte, com tarsos posteriores III a V completamente brancos ou apresentando pequeno anel escuro basal nos tarsômeros III e/ou V (Faran, 1980; Peyton et al., 1992). Suas formas imaturas desenvolvem-se em coleções líquidas no solo, desde os grandes cursos d'água até as pequenas poças.

As espécies que ocorrem no Brasil são eurigâmicas. Machos e fêmeas abrigam-se no ambiente silvestre, semi-silvestre ou rural antes de formarem o vôo nupcial. As fêmeas de algumas espécies brasileiras de Nyssorhynchus podem invadir a habitação humana, mas geralmente não utilizam este ambiente como abrigo, não permanecendo ali prolongadamente. É raro o encontro de machos deste subgênero dentro dos domicilios. 
Anopheles darlingi Root, 1926

Distribuição geográfica. É encontrado em áreas de baixas altitudes, quase sempre associado aos grandes cursos d'água e florestas do interior, mas ocorre também no litoral. Está amplamente distribuído no território sul-americano a leste dos Andes, na Colômbia, Venezuela, Bolívia, Peru, Paraguai, Argentina, Brasil e nas Guianas. A oeste dos Andes só foi encontrado em Chaco, Colômbia. Sua distribuição é descontínua ao norte da Venezuela, pois esse mosquito tem sido encontrado em áreas centro-americanas entre o sul do México, Belize, Honduras e Guatemala.

No Brasil, só não é encontrado nas áreas secas do Nordeste, no extremo Sul (abaixo da foz do rio Iguaçu) e nas áreas de elevada altitude.

Biologia. Utiliza as grandes coleçōes líquidas para o desenvolvimento de suas formas imaturas, tais como: lagoas, açudes, represas e bolsōes formados nas curvas dos rios onde há muito pouca correnteza. Seus criadouros são, por excelência, de águas profundas, limpas, pouco turvas e ensolaradas ou parcialmente sombreadas, onde suas larvas e pupas habitam as margens, escondidas entre a vegetação emergente ou flutuante e os detritos vegetais caídos na superfície líquida. Estes criadouros são utilizados, indiscriminadamente, durante todo $o$ ano $\mathrm{e}$, por serem permanentes, funcionam como focos de resistência durante a estação mais seca. Contudo, durante a estação chuvosa, An. darlingi pode empregar uma grande variedade de coleções líquidas de tamanho e profundidade menores, tais como: valas, poças e impressões de patas de animais.

$E$ o anofelino indígena mais antropofilico e de comportamento endófilo mais acentuado. Nas áreas rurais da Amazônia, por exemplo, pode atacar mamíferos de grande porte quando estes pernoitam no peridomicílio, mas o faz em número comparativamente menor que o surpreendido sugando o homem (Deane et al., 1949; Oliveira-Ferreira et al., 1992). Costuma atacar o homem, dentro das casas, nas horas mais altas da noite. Principalmente em áreas onde as habitações são borrifadas internamente com inseticidas, também pode atacar o homem, em elevada densidade, na imediata vizinhança das casas e nas primeiras horas da noite. Mas há áreas no país, que correspondem à minoria, onde An. darlingi pode ser preferentemente exófago (Guedes et al., 1953; Forattini, 1987; Lourenço-de-Oliveira, 1989).

De qualquer modo, nas áreas onde An. darlingi está presente, ele é geralmente o anofelino mais freqüente dentro do domicílio (Deane et al., 1948; Deane, 1986; Lourenço-de-Oliveira et al., 1989; Klein \& Lima, 1990).

No passado, quando ainda não se utilizavam os inseticidas residuais aplicados às paredes internas das casas, elevado número de fêmeas de An. darlingi era surpreendido em repouso dentro das habitações, mesmo durante as horas claras do dia. Contudo, hoje, nas moradias borrifadas com DDT e outros inseticidas, sabe-se que a grande maioria das fêmeas deste anofelino parte para o extra domicílio poucos minutos após sua alimentação sanguínea, procurando se abrigar na vegetação densa, cerca de $10 \mathrm{~cm}$ de altura do solo. Mas as fêmeas que que porventura repousarem no interior das casas o farão essencialmente à noite e preferencialmente nos dois metros mais baixos das paredes, embora já se te- 
nha observado repousos no teto das moradias dedetizadas (Deane \& Damasceno, 1948; Elliot, 1972; Roberts et al., 1987; Deane, 1989; Quiñones \& Suarez, 1990).

As populações brasileiras de An. darlingi, até hoje investigadas, não apresentam resistência aos inseticidas usados em seu controle, tais como DDT e deltametrina, embora a espécie pareça não exibir irritabilidade e apresente resistência ao DDT em áreas colombianas (Quiñones \& Soares, 1989; Suarez et al., 1990).

Em seu território no Brasil é encontrado picando durante todo o ano, rareando um pouco no final da estação seca e abundando no final da chuvosa, mais propriamente na transição entre as épocas de maiores e menores pluviosidades (Charlwood \& Hayes, 1978; Charlwood, 1980; Klein \& Lima, 1990). Aparentemente, as chuvas torrenciais, freqüentes durante a estação chuvosa, produzem elevada mortalidade dentre as larvas e pupas de An. darlingi, pois as enxurradas podem arrastá-las das margens dos criadouros, afogando-as e interrompendo o seu desenvolvimento.

O ciclo de oviposição de An. darlingi, isto é, o tempo entre cada alimentação sanguínea, parece ser de três dias, incluindo um dia durante o qual as fêmeas paridas descansam antes de retornarem a sugar sangue após a postura (Charlwood, 1980).

Tem-se verificado certa variação no ciclo nictemeral de An. darlingi de acordo com a área do território brasileiro e conforme a época do ano. De modo geral, acredita-se que a espécie apresenta apenas um pico de atividade hematofágica situado em torno da meia-noite ou dois picos crepusculares - um matutino e um vespertino - mas com atividade ininterrupta durante toda a noite (Deane et al., 1948; Forattini, 1962; Roberts et al., 1987; Lourenço-de-Oliveira et al., 1989; Klein \& Lima, 1990; Rosa Freitas et al., 1992). A espécie pode ser oportunista e sugar durante o dia, inclusive transmitindo malária, quando humanos se aproximam de seus abrigos e criadouros (Deane, 1989).

As variações no ciclo nictemeral da hematofagia e na freqüência às habitações humanas exibidas por $A$ n. darlingi, somadas às diferenças encontradas no perfil de isoenzimas e nos caracteres dos cromossomos politênicos já assinalados em populações deste anofelino, levaram a suspeitas de que se trate de um complexo de espécies crípticas. Porém, até quanto sabemos, ainda não foram detectadas suficientes diferenças morfológicas, bioquímicas ou moleculares entre populações de An. darlingi que comprovem tal desconfiança (Kreutzer et al., 1972; Rosa-Freitas et al., 1992). Indivíduos com fenótipo aberrante, isto é, apresentando marcação escura nos tarsos III e IV posteriores, têm sido detectados em população centro-americana desse anofelino (Harbach et al., 1993).

Relação com a malária. An. darlingi é, sem dúvida, o principal vetor de malária no Brasil. É vetor primário, altamente susceptível aos plasmódios humanos e capaz de transmitir malária dentro e fora das casas, mesmo quando sua densidade está baixa.

Na Amazônia, onde a malária humana parece estar praticamente confinada no Brasil, An. darlingi é o anofelino que melhor e mais rapidamente se beneficia das alterações que o homem produz no ambiente silvestre. Assim, a colonização desta região do país, implicando na substituiçāo da floresta por modestas 
plantaçōes, pastagens ou garimpos, geralmente afasta os anofelinos de hábitos mais silvestres e propicia ambiente muito favorável ao darlingi, provocando grande aumento de sua densidade e, subseqüentemente, da incidência do paludismo.

Hoje, acredita-se que o grosso da malária humana na nossa Amazônia é transmitido pelo $A n$. darlingi, no peridomicílio e no início da noite. Entretanto, não se despreza a importância da endofagia exibida por esse anofelino, que consiste na única espécie com densidade e freqüencia suficientes para veicular a moléstia no interior do domicílio.

Tem sido o anofelino brasileiro mais freqüentemente encontrado naturalmente infectado com esporozoítos de plasmódio e sua distribuição geralmente coincide com as áreas mais atingidas pelo paludismo. Infecções naturais em An. darlingi têm sido reportadas, desde a década de 1930, em numerosas localidades brasileiras, em algumas das quais é o único transmissor importante. An. darlingi é o único anofelino brasileiro no qual foram detectadas infecções naturais pelos três plasmódios que causam malária humana nas Américas - P. vivax, P. falciparum e P. malariae - sendo o mais suscetível, experimentalmente, a esses parasitos (Rachou, 1958; Deane, 1986; 1989; Arruda et al., 1989; Klein et al., 1991a, b).

Relação com outras enfermidades. An. darlingi já foi encontrado com larvas infectantes de $W$. bancrofti, em Belém do Pará, onde a endemicidade desta filariose é assegurada pelo $C x$. quinquefasciatus. Seu papel na transmissão da filariose deve ser secundário, ou local (Causey et al., 1945; Rachou, 1956).

\section{Anopheles aquasalis Curry, 1932}

Distribuição Geográfica. Seu nome denuncia sua preferência por águas dotadas de certa salinidade, que obviamente são mais comuns no litoral. Assim, esta espécie é encontrada numa faixa litorânea longa e, de certa forma estreita, de próximo ao paralelo $24^{\circ} 30^{\prime}$ S (Peruíbe, São Paulo) até a Costa Rica, no lado Atlântico, e desde esse ponto até o Golfo de Guaiaquil, no Equador, que é o seu limite sul na costa pacifica. Ocorre também nas Antilhas Menores, em Trinidad e Tobago.

Algumas localidades brasileiras distantes mais do que $100 \mathrm{~km}$ do litoral são atingidas pelo An. aquasalis, mas sempre quando o solo é rico em cloretos, como é o caso de algumas áreas do sertão nordestino, ou quando o terreno sofre invasão das marés, como ocorre na área de Belém, Pará (Deane et al., 1948).

Biologia. Devido ao fato de os criadouros com teor relativamente elevado de cloreto de sódio serem mais propícios para o desenvolvimento de suas larvas do que aqueles de água doce, An. aquasalis tem sua distribuição determinada por essa peculiaridade. Seus criadouros são as coleçōes de águas paradas e salobras, de tamanho pequeno ou médio, transitórias ou semipermanentes, ensolaradas ou parcialmente sombreadas, que ocorrem nas áreas de baixadas litorâneas. Os terrenos baixos temporariamente inundados pelas marés e as poças e valas formadas na época das chuvas em solos salgados são os locais mais prováveis de se achar o An. aquasalis criando.

É uma espécie cuja densidade populacional é muito diretamente influenciada pela presença de chuvas, característica imposta pela relativa transitorieda- 
de de seus criadouros. An. aquasalis é, progressivamente, mais raro com o avançar da época mais seca, podendo quase desaparecer no final desta estação e ser altamente abundante quando iniciam ou finalizam os meses chuvosos.

É considerado um mosquito zoofílico e essencialmente crepuscular, atacando animais como a vaca e o cavalo com muito mais intensidade que ao homem. Também é um anofelino exófilo, entrando nas casas para picar apenas quando sua densidade está elevada. Exceção se faz em certas localidades do litoral nordestino, onde tem sido bastante comum picando o homem dentro das habitações, mesmo nas horas mais altas da noite (Deane et al., 1948; Lucena, 1950; Rachou, 1958; Flores-Mendoza, 1994).

Tais variações no comportamento de An. aquasalis em relação à invasão ao domicílio humano sugeriram a existência de populações, ou até mesmo variedades diferentes nesta espécies. É possível que An. aquasalis seja um complexo de espécies crípticas (Conn et al., 1993).

Mesmo nos locais onde An. aquasalis invade as moradias em maior proporção, as suas fêmeas e machos não costumam repousar longamente dentro deste ambiente, ou seja, as habitações humanas não lhes são, verdadeiramente, abrigos. Sabe-se que, no Sudeste, por exemplo, os machos e fêmeas não ingurgitadas preferem se abrigar e repousar em troncos de árvores $\mathrm{e}$ folhas de bananeira caídos no solo, bem úmidos, enquanto as fêmeas repletas de sangue escondem-se no meio das moitas de capim (Flores-Mendoza \& Deane, 1993).

Relação com a malária. Diante dos hábitos supracitados, pode-se ter uma noção da capacidade vetorial desse anofelino. An. aquasalis é um transmissor muito menos importante que o An. darlingi. Porém, é considerado vetor primário da malária nas zonas áridas do Nordeste, em Belém e Amapá, na Amazônia, além de ter sido várias vezes detectado com infecção natural nos Estados do Rio de Janeiro e São Paulo (Galvão et al., 1942; Deane et al., 1948; Rachou, 1958).

An. aquasalis é capaz de transmitir o paludismo somente em locais e ocasiões em que está em elevada densidade, quando tem oportunidade de atacar o homem em maior número. Essa peculiaridade tem sido constatada em outros anofelinos que também exibem pico máximo da atividade hematofágica, em humanos, no início da noite, tais como An. albitarsis e as espécies do subgênero Kerteszia (Elliot, 1972; Deane, 1986).

Relação com outras enfermidades. É considerado vetor secundário da filariose bancroftiana no Brasil, pois fora encontrado com larvas infectantes de $W$. bancrofti, em Belém, Pará. Lá, o transmissor primário é o Culex quinquefasciatus, o qual mantém os elevados índices de microfilaremia local, situação que propicia a infecção do An. aquasalis.

\section{Anopheles albitarsis Lynch-Arribálzaga, 1878}

Distribuição geográfica. É o anofelino mais comum e amplamente distribuído no Brasil. Seu território nas Américas corresponde ao nordeste da Argentina, todo o Uruguai, o Paraguai, o Brasil, a Venezuela e as Guianas; ocorre tam- 
bém na Colômbia, Panamá, Costa Rica, Honduras, Guatemala e Trinidad. Não ocorre no ocidente sul-americano.

É mais comum nas áreas de planície e baixada, sendo também abundante nos planaltos, mas torna-se raro à medida que se avança para terrenos com forte declive ou para dentro das florestas.

Biologia. An. albitarsis é, talvez, o Nyssorhynchus relacionado com a transmissão da malária humana que tem maior ecletismo em todos os aspectos de seus hábitos. No que se refere aos criadouros, é quase destituído de preferência, criando-se nos mais variados tipos de coleçōes líquidas, temporárias ou não, naturais e artificiais, expostas à luz ou sombreadas. Porém, as larvas de An. albitarsis são mais abundantes nos alagados com capim (campos ou pastagens), de água doce e limpa, que se formam nos descampados, de forma que os criadouros são ensolarados, mas sendo a luz solar um pouco abrandada pela vegetação emergente.

Este anofelino é comumente encontrado picando durante todo o ano, mas é bem mais abundante na estação chuvosa, quando são ampliados os seus criadouros.

Em algumas áreas do Brasil, An. albitarsis pode entrar nas casas e se alimentar no homem. Contudo, na maior parte de seu território, incluindo o Nordeste seco e o sertão das regiões Sudeste e Centro-Oeste, é decididamente zoofílico e exofilo. Prefere muito mais atacar animais, como equídeos, que o homem e aves (Deane et al., 1948; Deane et al., 1949).

Relação com a malária. Na verdade, o anofelino em questão apresenta consideráveis variações morfológica, bioquímica e/ou molecular e comportamental em seu território, o que se reflete numa heterogeneidade no seu papel como vetor do paludismo. Assim, An. albitarsis é considerado um complexo de espécies crípticas, cujos membros ainda não estão devidamente separados, com uma única exceção: An. deaneorum Rosa-Freitas, 1989 (Kreutzer et al., 1976; Deane, 1988; RosaFreitas et al., 1990; Klein et al., 1990). Por isso, provisoriamente, tratamos An. albitarsis como uma única espécie.

Podemos considerá-lo, desta forma, vetor secundário ou, no máximo, local, visto que em poucas localidades foi encarado como o único transmissor. A maioria das infecções naturais encontradas neste anofelino tratava-se apenas de oocistos. Mas já foram detectadas algumas infecções naturais, através de imunensaios que acusaram a presença de proteína circunsporozoíta de $P$. vivax e $P$. falciparum em exemplares de An. albitarsis. Esse anofelino é, experimentalmente, pouco suscetível a $P$. vivax e não parece permitir a invasão de suas glândulas salivares por esporozoítos de P. falciparum (Rachou, 1958; Arruda et al., 1986; Deane 1986; 1988; Klein et al., 1991a, b).

\section{Anopheles deaneorum Rosa-Freitas, 1989}

Distribuição geográfica. Esta espécie foi recentemente separada do complexo albitrasis. Parece estar restrita ao noroeste do Brasil, tendo sido detectada nos Estados do Acre e Rondônia, em áreas onde coexiste com populações de $A n$. albitarsis (lato sensu). 
Biologia. Existem poucos dados sobre a biologia de An. deaneorum, entretanto tem-se a impressão de que, de modo geral, seus hábitos coincidem com os de An. albitarsis. Contudo, An. deaneorum parece ter tendência a invadir as habitaçōes humanas com maior assiduidade que An. albitarsis.

A maior densidade de An. deaneorum ocorre principalmente no início da estação menos chuvosa, porém quando os rios amazônicos ainda têm os seus níveis elevados, mantendo alagados os terrenos baixos às suas margens. É um anofelino preferentemente crepuscular e exófilo, embora possa ser visto atacando o homem em abundância dentro das casas, mas não chega a superar ou se igualar ao An. darlingi (Rosa-Freitas, 1989; Klein \& Lima, 1990; Klein et al., 1990).

Relação com a malária. An. deaneorum parece ser vetor secundário ou local do paludismo humano. Assim é considerado em áreas de Rondônia, onde An. darlingi é, sem dúvida, o vetor principal. Ali An. deaneorum é, experimentalmente, tão suscetível quanto o An. darlingi aos $P$. vivax e $P$. falciparum. An. deaneorum também parece ser capaz de veicular esses parasitos na natureza (Klein et al., 1991a, b; Branquinho et al., 1993).

\section{Anopheles braziliensis Chagas, 1907}

Distribuição geográfica. É restrito à América do Sul (lado oriental dos Andes), ocorrendo em quase todo o Brasil (seu limite sul parece ser o Estado de São Paulo) e parte da Bolívia, Colômbia, Venezuela, Guianas e Trinidad. É mais raro no litoral atlântico e nas áreas mais secas do sertão do que no interior, de modo geral.

Biologia. An. braziliensis cria-se preferencialmente em coleções de águas doces e límpidas, sempre renovadas, ensolaradas, com fundo arenoso e vegetação emergente. Esses criadouros são representados principalmente pelos córregos e águas represadas com sangradouro (Deane et al., 1948).

Como já dissemos, é zoofílico, exófilo e crepuscular como os demais vetores secundários do paludismo. Porém, An. braziliensis é, algumas vezes, encontrado picando durante o dia, especialmente quando o hospedeiro está relativamente próximo do seu criadouro.

Relação com a malária. Tem quase nenhuma relação com a veiculação da malária no Brasil. Foi poucas vezes detectado conduzindo proteína CS de plasmódios humanos ( $P$. vivax e $P$. falciparum) em localidades amazônicas, nas quais a endemicidade era, indubitavelmente, mantida pelo An. darlingi. Além disso, An. braziliensis parece não permitir a invasão de suas glândulas salivares por esporozoítas de $P$. vivax, em condiçōes experimentais. Portanto, An. braziliensis pode ser considerado, no máximo, um vetor secundário ou local (Deane et al., 1948; Deane, 1986; Lourenço-de-Oliveira et al., 1990; Klein et al., 1991b).

\section{Anopheles nuneztovari Galbadon, 1940}

Distribuição Geográfica. É um anofelino essencialmente sul-americano e sobretudo amazônico. Seu limite norte são as Guianas, Venezuela, Colômbia e porção leste do Panamá, e ao sul as áreas ao norte do Peru, Bolívia e os Estados da Amazônia brasileira. 
Biologia. Constituem seus criadouros preferenciais as coleçðes de águas doces e turvas, de pequeno ou médio porte, ensolaradas ou levemente sombreadas, muitas vezes sem vegetação. São representados pelas poças de água de chuva, impressões de rodas e de patas de animais, barreiros e pequenas lagoas e, nas florestas, alagados que se encontram nas clareiras batidas pelo sol (Deane et al., 1948).

An. nuneztovari é, no Brasil, essencialmente zoofílico e crepuscular, sendo bem mais freqüente dentro da floresta que fora dela, isto $e$, nos ambientes modificados pelo homem. Pode atacar o homem, especialmente fora de casa, mas volta sua agressividade para animais quando estes estão presentes.

A ocorrência de variações bioquímicas e citogenéticas e, principalmente, comportamentais, sugerem a existência de duas populações alopátricas em An. nuneztovari. Uma delas, de hábitos exofágico, zoofílico e crepuscular vespertino, ocorre no Brasil, Suriname e Equador. Esta população de An. nuneztovari se contrapõe a uma outra que procura atacar o homem dentro das habitações, prefere as horas próximas à meia-noite para o hematofagismo, ocorrendo particularmente em áreas da Venezuela e Colômbia (Elliot, 1992; Kitzmiller et al., 1973; Conn, 1990; Rubio-Palis \& Curtis, 1992).

Em nível morfológico, fêmeas de An. nuneztovari têm exibido variações no padrão das manchas das asas, que podem confundir durante o processo de identificação de espécimes obtidos na natureza. Como nos referimos na chave dicotômica correspondente (p. 64), a maioria das fêmeas de An. nuneztovari apresenta a mancha pré-umeral escura de comprimento igual ou maior que a mancha clara seguinte (umeral clara). Porém, em alguns casos, têm-se observado o inverso (Deane et al., 1947; Delgado \& Rubio-Palis, 1992; 1993), podendo os espécimens em exame serem confundidos com An. evansae. Nesse caso, sugerimos prestar atenção à distribuição geográfica dos dois anofelinos e estender os estudos às fases imaturas (ovos e larvas) e à genitália masculina da população em exame.

Relação com a malária. Como nos referimos, têm sido encontradas variações em seu comportamento, que, obviamente, se refletem no seu envolvimento com a transmissão do paludismo no Brasil e em países vizinhos, como Venezuela, Colômbia e Peru. Nestes três últimos países é considerado vetor importante, enquanto, até recentemente, não era encarado como transmissor habitual no Brasil (Elliot, 1972; Hayes, 1982; Deane, 1986; 1988; Rubio-Palis et al., 1992). Na década de 1980 foi encontrado naturalmente infectado ( $P$. vivax) em algumas localidades da Amazônia brasileira, onde geralmente o An. darlingi estava presente e An.nuneztovari poderia ser apenas vetor secundário (Arruda et al., 1986).

\section{Anopheles triannulatus (Neiva \& Pinto, 1922) (lato sensu)}

Distribuição Geográfica. Como se pode notar pelas chaves dicotômicas apresentadas atrás, An. triannulatus tem duas subespécies ou variedades, que são: An. triannulatus triannulatus (Neiva \& Pinto, 1922) e An. triannulatus davisi Peterson \& Shannon, 1927. Esta última é muito freqüente e de distribuição geográfica mais ampla do que a primeira. An. triannulatus triannulatus é encontrado 
muito raramente e em pontos isolados no Brasil, exceto no oeste do Mato Grosso do Sul, onde é tão ou mais abundante que a variedade davisi.

Considerando An. triannulatus (lato sensu) podemos dizer que é encontrado principalmente na grande porção leste aos Andes do continente sul-americano, mas também ocorre a oeste, desde o Peru até a Nicarágua. Ao sul, no lado oriental, alcança seu limite no nordeste argentino.

Biologia. Prefere criar em lagoas (rasas ou fundas), corixas e grandes poças d'água, bem expostas ao sol, porém com rica vegetação flutuante, como os alfaces-d'água (Pistia), os aguapés (Eichornia) e outros, e também fartas em gramíneas e outras plantas emergentes. Muitas vezes, considerando-se apenas os anofelinos, as lagoas cobertas de aguapés e alfaces-d'água são criadouros quase exclusivos de An. triannulatus (Deane et al., 1948), principalmente da variedade davisi. Devido às poucas informações a respeito dos criadouros da variedade triannulatus, pouco podemos especular sobre a existência de diferenças entre os seus criadouros e os de davisi.

Sabe-se que ambas as variedades são essencialmente zoofílicas, exófilas e crepusculares. Atacam o homem, mas em números muito menores que aos outros animais, como equídeos e bovinos (Galvão \& Lane, 1940; Deane et al., 1948; Lourenço-deOliveira, 1989). Sabe-se também que An. triannulatus (lato sensu) demonstra preferência por picar nos extratos mais altos das florestas (Deane et al., 1971).

Relação com a malária. Este anofelino não é vetor primário de malária no Brasil. An. triannulatus (provavelmente davisi) já foi encontrado naturalmente infectado com oocistos, fora do Brasil, e só recentemente tem sido detectado infectado (através de imunensaios para a pesquisa de proteína CS), em localidades da Amazônia brasileira, onde o An. darlingi é o responsável pela manutenção da endemicidade do paludismo (Forattini, 1962; Deane, 1988; Oliveira-Ferreira et al., 1990). Além disso, An. triannulatus parece ser pouco suscetivel aos $P$. vivax e $P$. falciparum, em condições experimentais, pois pequeno número de esporozoítos conseguem alcançar e invadir as suas glândulas salivares (Klein et al., 1991a, b).

\section{Anopheles oswaldoi Peryassú, 1922}

Distribuição Geografica. Está amplamente distribuído em todos os países na América do Sul a leste dos Andes (exceto o Chile), desde o norte do Uruguai e o nordeste da Argentina até a Costa Rica. Também já foi coletado em Trinidad.

No Brasil é abundante dentro e próximo às áreas florestadas e bastante chuvosas, e raro ou ausente nas grandes extensões de campos (descampados). Não ocorre nas zonas secas nordestinas (Deane et al., 1948).

Biologia. Seus criadouros preferenciais são as poças, alagados, lagoas pequenas ou remansos de córregos, todos dentro das florestas, ou seja, sombreados. Suas formas imaturas são mais raramente encontradas em locais ensolarados como barreiros, cacimbas, valas e depressões naturais do terreno. 
É um anofelino zoofílico, exófilo e essencialmente crepuscular. Invade o domicilio muito ocasionalmente para picar o homem, enquanto ataca animais, como cavalo e vaca, com bastante agressividade, perto ou longe das casas (Deane et al., 1948; Lourenço-de-Oliveira et al., 1989).

Relação com a malária. Embora sua distribuição não coincida com a do paludismo no Brasil, An. oswaldoi vem sendo recentemente considerado vetor potencial em algumas áreas (Rondônia, Pará e Acre), por ser encontrado naturalmente infectado com plasmodios humanos ( $P$. vivax e $P$. falciparum). Tais infeç̧ões devem ter sido adquiridas em epidemias promovidas pelo An. darlingi, pois este sempre estava presente nas áreas pesquisadas (Arruda et al., 1986; Oliveira-Ferreira et al.,1990; Klein et al., 1991a, b). Contudo, suspeita-se que a população de An. oswaldoi que, eventualmente, ataca o homem em elevados números no ambiente modificado do peridomicílio, corresponda a uma variedade ou mesmo a uma espécie distinta daquela que abunda no seio da mata e não se afasta muito dos domínios silvestres (Klein \& Lima, 1990). Pode ser que a população com maiores possibilidades de entrar em contacto com o homem seja boa vetora do paludismo. Talvez seja a população com que Branquinho et al. (1993) trabalharam, no Acre, onde $A n$. oswaldoi foi incriminado, através de imunensaio (ELISA), como vetor de P. vivax (padrão e variante VK247), P. falciparum e P. malariae.

\section{Outros Nyssorhynchus}

Além dos anofelinos supracitados, outras espécies, como An. strodei Root, 1926, An. evansae (Brethes, 1926) e An. galvaoi Causey Deane \& Deane, 1945, têm sido esporadicamente detectadas com infecção natural por plasmódio (principalmente oocistos), as quais detêm pouca atenção dos especialistas. Esses mosquitos são essencialmente zoofilicos e exofilos. Seguramente se infectam no auge das epidemias promovidas por um vetor primário competente, além do que, sua freqüência nunca está relacionada com a da malária (Deane, 1986; Tadei et al., 1988; Lourenço-de-Oliveira et al.,1989; Oliveira-Ferreira et al., 1990).

Dados sobre a biologia de outros Nyssorhynchus podem ser obtidos nas publicações de Deane et al. (1948), Forattini (1962) e Elliot (1972).

\section{Subgênero Kerteszia Theobald, 1905}

Os anofelinos deste subgênero são caracteristicamente bastante delicados, com pernas listradas de branco e preto (aneladas) e escudo dotado de quatro faixas longitudinais escuras.

Os adultos são eurigâmicos. Suas formas imaturas sempre se desenvolvem em criadouros do tipo "recipiente natural", principalmente em água que se acumula nas axilas das folhas de bromélias. Dependendo de sua localização, as bromélias são conhecidas como: terrestres (implantadas no solo), rupestres (em pedras) e epífitas (em árvores). Todos os tipos são chamados popularmente de gravatás. 
Mosquitos deste subgênero foram considerados os vetores primários da malária, uma vez endêmica, no sul do Brasil e responsáveis pelas epidemias no litoral fluminense e paulista, junto à Serra do Mar (Rachou, 1958).

\section{Anopheles cruzii Dyar \& Knab, 1908}

Distribuição geográfica. É restrito ao litoral brasileiro, do Rio Grande do Sul até os estados nordestinos, possivelmente Sergipe, seguindo preponderantemente a distribuição original da Mata Atlântica e as matas de galerias do Sul, por serem ambas muito ricas em gravatás.

Há algumas citações de encontros de An. cruzii em localidades fora da distribuição supracitada, mas que necessitam ser avaliadas (Zavortink, 1973).

Biologia. An. cruzii cria-se apenas em gravatás. Prefere as bromélias epífitas e terrestres, mas situadas em locais protegidos dos raios solares, ou seja, na sombra produzida pelas copas das árvores. E também encontrado, porém com muito menor freqüuência, em gravatás rupestres e/ou expostos ao sol.

Devido a sua preferência por locais sombreados onde, por consequiência, a evaporação da água contida nos aquários das bromélias é bem mais lenta que nos gravatás ensolarados, An. cruzii pode criar-se, indiscriminadamente, em plantas de tamanho grande ou bem pequeno. Já se tem coletado larvas desse anofelino em gravatás pequenos, bem estreitos, contendo apenas um total de 10 $\mathrm{ml}$ de líquido (Rachou, 1958).

Sua densidade populacional está diretamente relacionada com a abundância de gravatás e de elevados índices de umidade relativa do ar provocados pelas chuvas e pela lenta evaporação. torâneas.

É geralmente muito abundante dentro das matas úmidas das encostas li-

An. cruzii, tal como os demais Kerteszia, é muito oportunista e eclético. A presença de uma fonte sanguínea torna-o imediatamente excitado, independentemente do horário ou do tipo de hospedeiro. Este anofelino ataca, indiscriminadamente, o homem, outros mamíferos e aves.

Dentro das matas sombreadas e úmidas, que servem para seu abrigo, $A n$. cruzii é encontrado picando tanto de dia como à noite, mas com forte aumento da atividade hematofágica no crepúsculo vespertino e nas primeiras horas da noite. Quando este anofelino tem que se deslocar para fora das matas para se alimentar de sangue, o faz principalmente ao crepúsculo.

An. cruzii é considerado um mosquito exófilo. Porém, em muitas localidades do Sul do Brasil e em épocas do ano de elevada densidade, invade as casas facilmente e com alta incidência, especialmente aquelas situadas próximo às matas onde ele cria. Em certas áreas de Santa Catarina, por exemplo, mais de $90 \%$ dos anofelinos capturados dentro das casas correspondem ao An. cruzii, mantendo uma média de mais de 20 exemplares picando um homem, em cada hora (Rachou, 1958). 
An. cruzii prefere picar nos níveis elevados das florestas, isto é, junto à copa das árvores, o que chamamos de acrodendrofilia. Tal acrodendrofilia é muito marcante na maioria das localidades estudadas, como por exemplo, no Horto Florestal da Cantareira, São Paulo (Deane et al., 1971), onde 99\% dos exemplares de $A n$. cruzii são coletados na copa das árvores contra apenas 1\% junto ao solo. Por outro lado, em áreas de elevada nebulosidade (umidade), como nas matas de encostas litorâneas de Santa Catarina, 58\% dos An. cruzii são surpreendidos picando junto a copa contra $42 \%$ ao solo.

Relação com a malária. An. cruzii é considerado vetor primário e importante no Brasil, desde as investigações de Lutz, na Serra do Mar, em 1898. Não divide a tarefa da transmissão da malária humana com outros anofelinos, senão com outros Kerteszia, em seus domínios territoriais na Região Sul do Brasil. É, junto com An. bellator e An. humunculus, vetor do que é conhecido como "malária de bromélias" ou "bromélia-malária", ou seja, paludismo transmitido por anofelinos que se criam em gravatás. A "malária de bromélias" ocorre, no Brasil, no litoral do Estado de São Paulo (em caráter epidêmico) e existiu, de forma endêmica, de São Paulo ao Rio Grande do Sul.

An. cruzii é transmissor de malária apenas nos locais onde atinge elevada densidade populacional, veiculando o paludismo dentro e fora das casas. Têm sido detectadas infecções naturais por plasmódio neste anofelino, mas estas ainda não foram testadas por métodos imunológicos para a identificação específica do parasito (Rachou, 1958; Deane, 1986).

Além de transmitir paludismo ao homem, An. cruzii é o único vetor natural conhecido de malária simiana no Brasil e nas Américas, veiculando os dois plasmódios de macacos do Novo Mundo - P. brasilianum e $P$. simium - ambos infectantes para o homem (Deane et al., 1970). Evidentemente, seu papel como vetor desta enzootia é restrito à sua distribuição geográfica.

Em algumas localidades onde a acrodendrofilia do An. cruzii é muito acentuada há apenas transmissão de malária simiana por este vetor, ao passo que em outras áreas onde ocorrem proporções quase semelhantes entre a sua densidade nas copas e junto ao solo, há transmissão das duas malárias, humana e simiana, concomitantemente (Deane et al., 1971).

\section{Anopheles bellator Dyar \& Knab, 1906}

Distribuiçäo Geográfica. Assim como o An. cruzii, é encontrado apenas no litoral, sendo sua distribuição estendida além do território brasileiro, existindo desde o Rio Grande do Sul até a Paraíba, saltando daí para a Guiana, Trinidad e o leste da Venezuela.

É raro dentro das matas, onde o An. cruzii predomina, mas torna-se abundante nas áreas abertas (fora das florestas do litoral sul e nas encostas de São Paulo e Rio de Janeiro).

Biologia. Seus hábitos são em tudo muito semelhantes aos do An. cruzii e outros Kerteszia: eclético quanto aos hospedeiros, exófilo e acrodendrófilo. Difere por preferir criar-se em bromélias rupestres, epífitas ou terrestres, mais ex- 
postas ao sol. Ao contrário do An. cruzii, prefere os gravatás de maior tamanho, que permitem o acúmulo de maior quantidade de água nas axilas de suas folhas. $O$ volume de líquido á acumulado permite o desenvolvimento larvário, apesar da evaporação a que é submetido, em decorrência da ensolação.

An. bellator é essencialmente crepuscular vespertino, prolongando sua atividade hematofágica às primeiras horas da noite. Por não se criar em ambientes fechados e protegidos da mata, An. bellator é raramente coletado durante as horas claras do dia, mas ataca o homem de maneira surpreendente, e em elevado número, ao pôr-do-sol.

Relação com a malária. A "malária-bromélia" no Brasil é também transmitida à custa desta espécie de anofelino, a qual só foi encontrada irfectada com esporozoítos de plasmódios em área endêmica de Santa Catarina (Rachou, 1958).

Assim como os demais Kerteszia, só transmite malária quando se encontra em elevada densidade populacional (Elliot, 1972).

\section{Anopheles homunculus Komp, 1937}

Distribuição Geografica. Sabe-se de uma distribuição geográfica descontínua para An. homunculus. Assim é que, ocorre no lado leste dos Andes na Colômbia e Bolívia e ao norte do continente sul-americano, ou seja, na Venezuela e em Trinidad. No Brasil, tem sido assinalado nos Estados de Santa Catarina, Paraná e São Paulo.

Tem sempre sido encontrado em áreas montanhosas de baixa altitude, nas vertentes voltadas para o mar, ou não.

Biologia. Sua biologia se parece muito com o que fora dito para os outros dois Kerteszia supracitados.

Destacam-se, entretanto, as seguintes características: An. homunculus prefere criar em bromélias de médio e pequeno porte, sombreadas, terrestres ou epífitas, situadas a baixa altura, ou seja, nas primeiras ramificações das árvores. Está relacionado às florestas úmidas e escuras, situadas em terrenos acidentados, evitando expor-se aos ambientes desprotegidos e ensolarados.

Dentro da floresta e nas suas imediaçōes, pode atacar o homem, mesmo durante o dia, tal como fora explicado para An. cruzii. A elevada nebulosidade, característica de certas áreas de Santa Catarina, produz no ambiente extra-florestal condições climáticas semelhantes às do interior da mata. Nessas localidades, An. homunculus é o anofelino mais freqüentemente encontrado picando o homem dentro das casas, embora seja genericamente bem mais comum no ambiente silvestre (Rachou, 1958).

Relação com a malária. É considerado vetor secundário ou local de malária no Sul do Brasil, tendo sido encontrado infectado mais de uma vez com oocistos e, em apenas uma ocasião, com esporozoítos de plasmódio nas glândulas salivares. Isto ocorreu, particularmente, em Blumenau, Santa Catarina. Fora desta localidade, An. homunculus nunca foi achado infectado por plasmódio. Ali, coexiste com An. cruzii, embora este tenha densidade muito menor que aquele. 
Os demais Kerteszia não têm importância epidemiológica no Brasil. Contudo, cabe ressaltar o encontro de um exemplar de An. neivai naturalmente infectado com esporozoítos de plasmódio não identificado, em área de malária simiana. Seu papel como vetor de malária humana ou simiana necessita ser avaliado, pois é considerado vetor do paludismo humano na costa oeste da Colômbia (Forattini, 1962, Deane, et al., 1970).

Dados adicionais sobre a biologia e relação das espécies de Kerteszia com a transmissão do paludismo podem ser obtidos em Rachou (1958), Forattini (1962), Aragão (1964) e Deane et al. (1971).

Afora os anofelinos acima citados, as demais espécies pertencentes aos outros subgêneros não têm sido acusadas de comprometimento com a veiculação do paludismo ou outra enfermidade do homem, no Brasil. São anofelinos dotados de elevada zoofilia e exofilia, preferindo o ambiente silvestre ou rural. Algumas espécies têm comportamento acrodendrofílico. Pode-se encontrar alguns dados sobre sua biologia e distribuição em Deane et al. (1948), Forattini (1962) e Deane et al. (1971).

\section{SUBFAMÍLIA CULICINAE}

É a maior subfamília, compreendendo 10 tribos, que reúnem 34 gêneros e cerca de 3.000 espécies.

As tribos de Culicinae que ocorrem no Brasil acham-se abaixo relacionadas. Estas tribos são as aceitas pelos autores atuais (Belkin et al., 1970; Knight \& Stone, 1977), pois até a década de 1960 os mosquitos da Família Culicidae eram agrupados nas tribos Anophelini (atual subfamília Anophelinae), Toxorhynchitini (atual subfamília Toxorhynchitinae), Culicini e Sabethini (que somadas compreendem a atual subfamília Culicinae).

Sete tribos e 18 gêneros ocorrem no Brasil:

TRIBOS

Aedeomyiini

Aedini

Culicini
GÊNEROS

Aedeomyia

Theobald, 1901

Aedes

Psorophora

Haemagogus

Meigen, 1818

Robineau-Desvoidy, 1827

Williston, 1896

Culex

Linnaeus, 1758

Deinocerites

Theobald, 1901 
TRIBOS

Mansoniini

Orthopodomyiini

Uranotaenini

Sabethini

\section{GÊNEROS}

Coquillettidia
Mansonia

Orthopodomyia

Uranotaenia

Sabethes

Limatus

Phoniomyia

Wyeomyia

Trichoprosopon

Shannoniana

Runchomyia

Johnhelkinia
Dyar, 1905

Blanchard, 1901

Theobald, 1904

Lynch-Arribalzaga, 1891

Robineau-Desvoidy, 1827

Theobald, 1901

Theobald, 1903

Theobald, 1901

Theobald, 1901

Lane \& Cerqueira, 1942

Theobald, 1903

Zavortink, 1979.

Todos estes gêneros têm como características principais aquelas já assinaladas para a subfamília Culicinae, ou seja: os adultos possuem a margem posterior do escutelo trilobada em ambos os sexos e os palpos das fêmeas são curtos, muito menores que a probóscide; os ovos são desprovidos de flutuadores; as larvas têm os espiráculos implantados na extremidade de um sifão, que pode ser de bem curto a muito longo.

A seguir, apresentamos chaves dicotômicas para a identificação das tribos e gêneros de Culicinae, modificadas a partir da apresentada por Belkin et al. (1970):

Chave para identificação das tribos e gêneros de Culicinae: adultos.

1. Veia Anal terminando antes da bifurcação da Veia

Cubital (Fig. 22.a). Uranotaenia

(Uranotaenini)

Veia Anal terminando após a bifurcação da Veia Cubital (Fig. 22.b) 
2. Mesoposnoto com cerdas, e algumas vezes com escamas; base da coxa-III em linha ou acima da base do mesomeron, o qual é muito pequeno (Fig. 22.c). 12 (Sabethini) Mesoposnoto sem cerdas; base da coxa posterior nitidamente ventral à base do mesomeron (Fig. 22.d)

3. Escudo revestido de escamas com brilho metálico azul, verde ou violeta, e sem cerdas pré-escutelares.

Escudo com revestimento diferente e com cerdas pré-escutelares

4. Cerdas pós-espiraculares presentes (Fig. 22.d) ................................................... 5

Cerdas pós-espiraculares ausentes (Fig. 22.c)

5. Escamas das veias da asa largas (Fig. 22.e); ápice do abdome das fêmeas truncado (Fig. 22.g) 6 (Mansoniini) Escamas das veias da asa estreitas (Fig. 22.f); ápice do abdome das fêmeas geralmente pontudo (Fig. 22.h) 7 (Aedini)

6. Fêmur com um anel claro pré-pical (Fig. 22.i). Coquillettidia Fêmur sem um anel claro pré-apical (Fig. 22.j) Mansonia

7. Cerdas pré-espiraculares presentes (Fig. 22.c) Psorophora Cerdas pré-espiraculares ausentes (Fig. 22.d) 8

8. Pleura com duas faixas verticais de escamas prateadas (Fig. 22.1) Haemagogus (parte) Pleura podendo ter escamas claras, porém não agrupadas em duas faixas verticais (Fig. 22.m) Aedes

9. Antena com segmentos flagelares curtos e grossos (Fig. 22.p); fêmures médio e posterior com tufo apical de escamas (Fig. 22.k) Aedeomyia (Aedeomyiini)

Antena com segmentos flagelares alongados (Fig. 22.q, r); fêmures sem tufos de escamas 

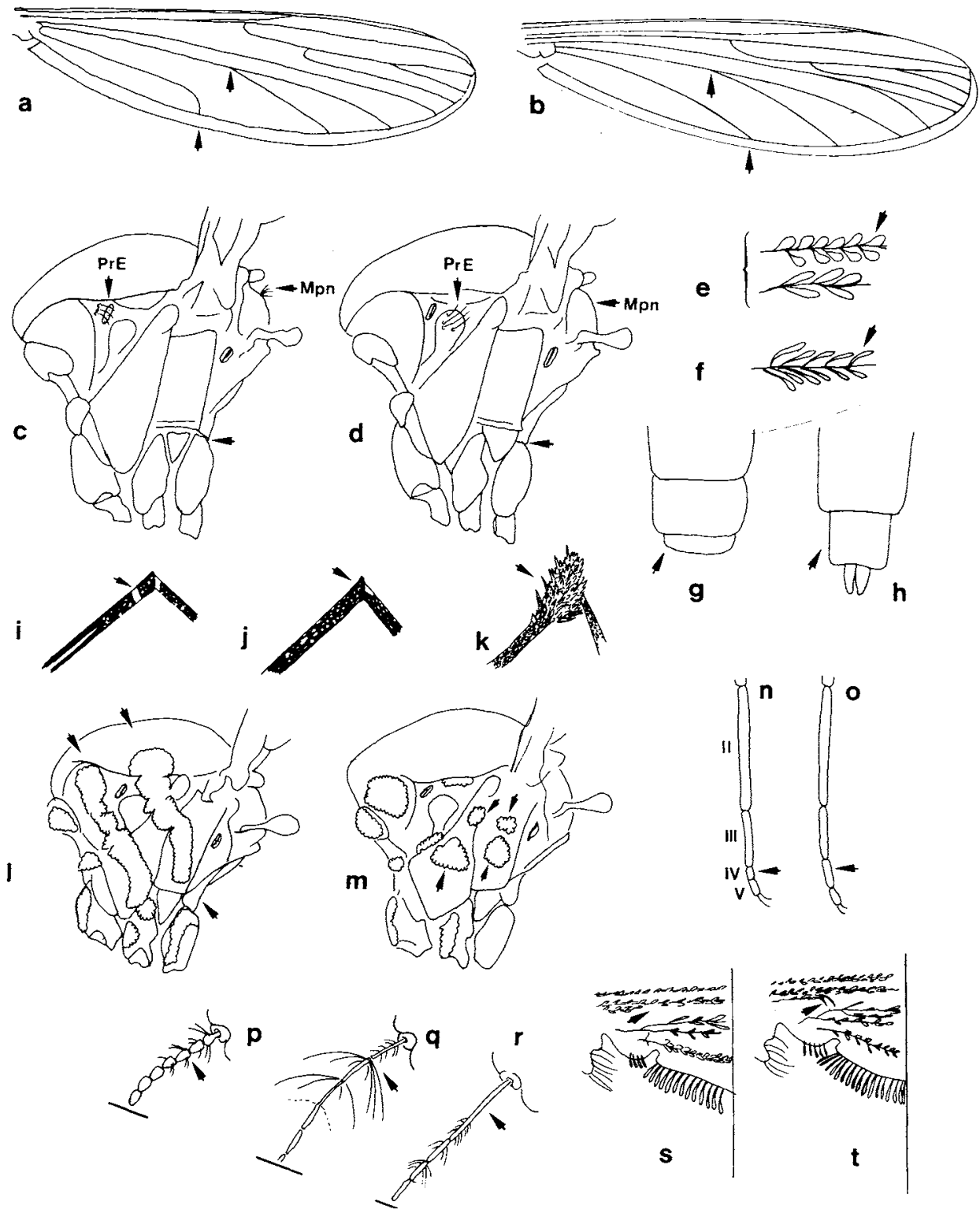

FIG. 22: Aspectos da morfologia externa de Culicinae adulto. Ilustraçōes referidas na chave dicotômica. a, b: asa; c, d, l, m: tórax, vista lateral [cerdas pré-espiraculares (PrE), pós-espiraculares (PoE) e do mesoposnoto (Mpn)l; e, f: escamas das veias da asa; $g$, h: ápice do abdome, vista dorsal; i-k: fêmur (F); $\mathbf{n}$, o: tarsos anteriores (artículos II a V); p-r: antena; $\mathbf{s , t}$ : asa, destaque da base. 
10. Tarso IV das pernas anteriores e medianas tão longo quanto largo Fig. 22.n).

Tarso IV das pernas anteriores e medianas mais longo que largo (Fig. 22.o) 11 (Culicini)

11. Primeiro segmento flagelar da antena duas vezes ou mais o comprimento do segundo (Fig. 22.r); remígio sem cerdas (Fig. 22.s) Deinocerites

Primeiro segmento flagelar da antena subigual ou mais curto que o segundo (Fig. 22.q); remígio com cerdas pequenas (Fig. 22.t)

12. Escudo ornamentado por escamas douradas e violetas formando desenho; área pré-espiracular somente com escamas, sem cerdas.

Escudo sem o tipo de ornamentação acima; área préespiracular com uma ou mais cerdas.

13. Occipício com uma linha de escamas eretas escuras, posteriormente (Fig. 23.a)

Occipício sem uma linha de escamas eretas escuras, posteriormente (Fig. 23.b)

14. Probóscide de comprimento menor ou subigual ao do fêmur anterior (Fig. 23.f); cerdas mesocatepisternais inferiores extendendo-se acima do bordo inferior do mesanepímero (Fig. 23.d) 15

Probóscide mais longa que o fêmur anterior (Fig. 23.g); cerdas mesocatepisternais inferiores geralmente não alcançam o bordo inferior do mesanepímero (Fig. 23.e)

FIG. 23: Aspectos da morfologia externa de Culicinae adulto. Ilustrações referidas na chave dicotômica. a, b: cabeça, vista dorso-frontal com destaque para o occipício; c, d, e: tórax, vista lateral [cerdas mesocatepisternais inferiores (MKi) e pré-alares (PA)]; f, g: cabeça e fêmur anterior (F), vista lateral; $h$, i: cabeça, vista lateral. 

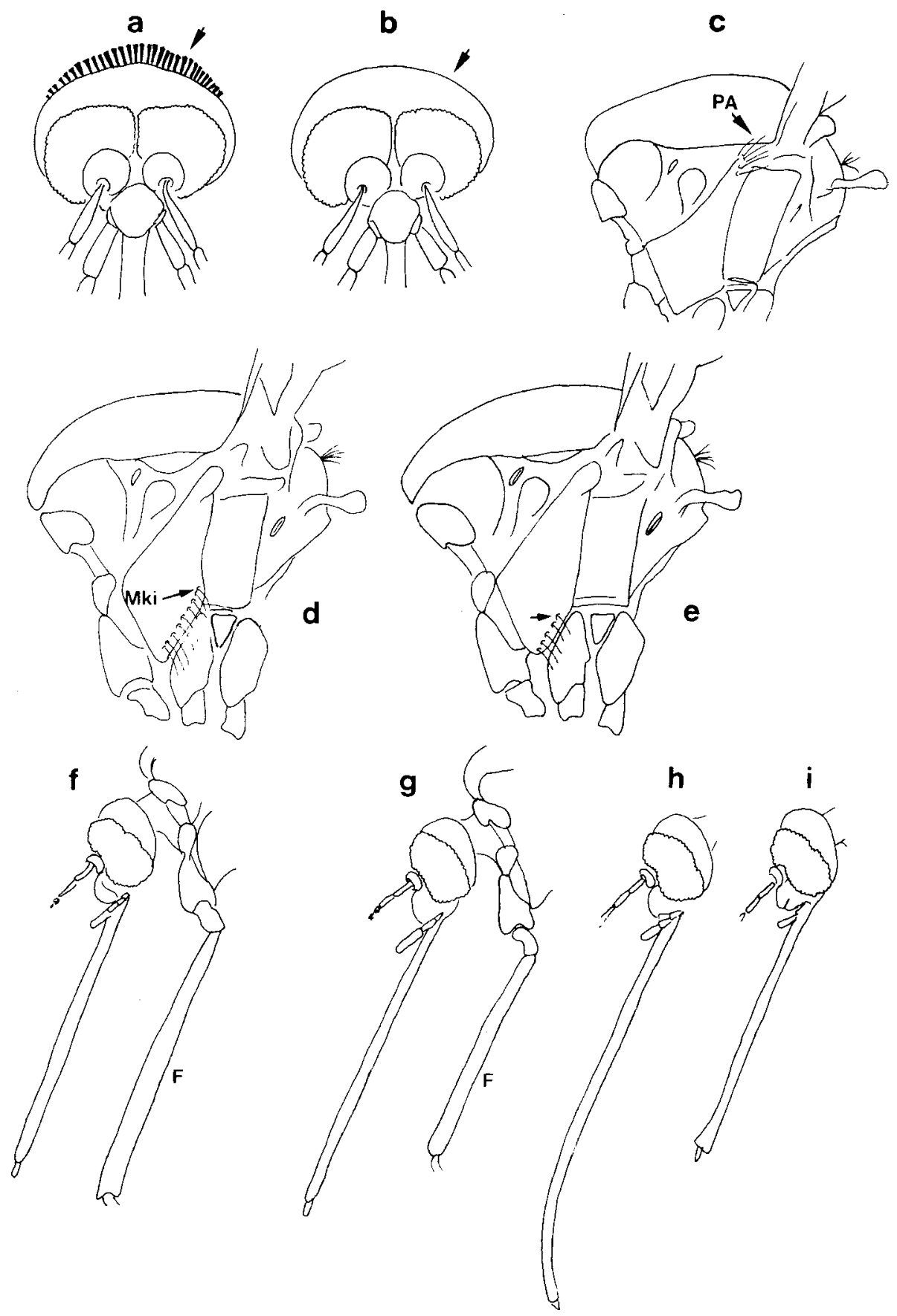
15. Tíbia posterior com mancha larga pós-mediana, formada por escamas claras. Shannoniana Tíbia posterior sem mancha clara pós-mediana Trichoprosopon

16. Tarsos medianos e posteriores com áreas de escamas claras e escuras Johnbelkinia Tarsos medianos e posteriores completamente escuros Runchomyia

17. Probóscide nitidamente mais longa que os fêmures anteriores (Fig. 23.g, h) 18

Probóscide mais curta ou equivalente aos fêmures anteriores (Fig. 23.f, i)

18. Probóscide muito longa, fina e curva na porção distal (Fig. 23.h) Phoniomyia Probóscide reta e dilatada na porção distal (Fig. 23.i) Wyeomyia (parte)

19. Escudo coberto por escamas de brilho metálico; cerdas pré-alares ausentes (Fig. 23.d, e) Sabethes

Escudo coberto por escamas sem brilho metálico, foscas; cerdas pré-alares presentes (Fig. 23.c) Wyeomyia (parte)

Chave para a identificação das tribos e gêneros de Culicinae: larvas.

1. Cerda 4-X composta por apenas um par de pêlos (Fig. 24.a) (Sabethini)

Cerda 4-X composta por pelo menos 4 pares de pêlos (Figs. 24.b, c e 25.c, d)

2. Sifão respiratório curto e cônico, com extremidade dotada de dentes muito quitinizados na face dorsal, modificado para a perfuração de tecidos vegetais (Fig. 24.c) Mansonia e Coquillettidia Sifão respiratório semicilíndrico, sem dentes quitinizados na extremidade dorsal (Figs. 24.b, f-h e 25.c, d) 


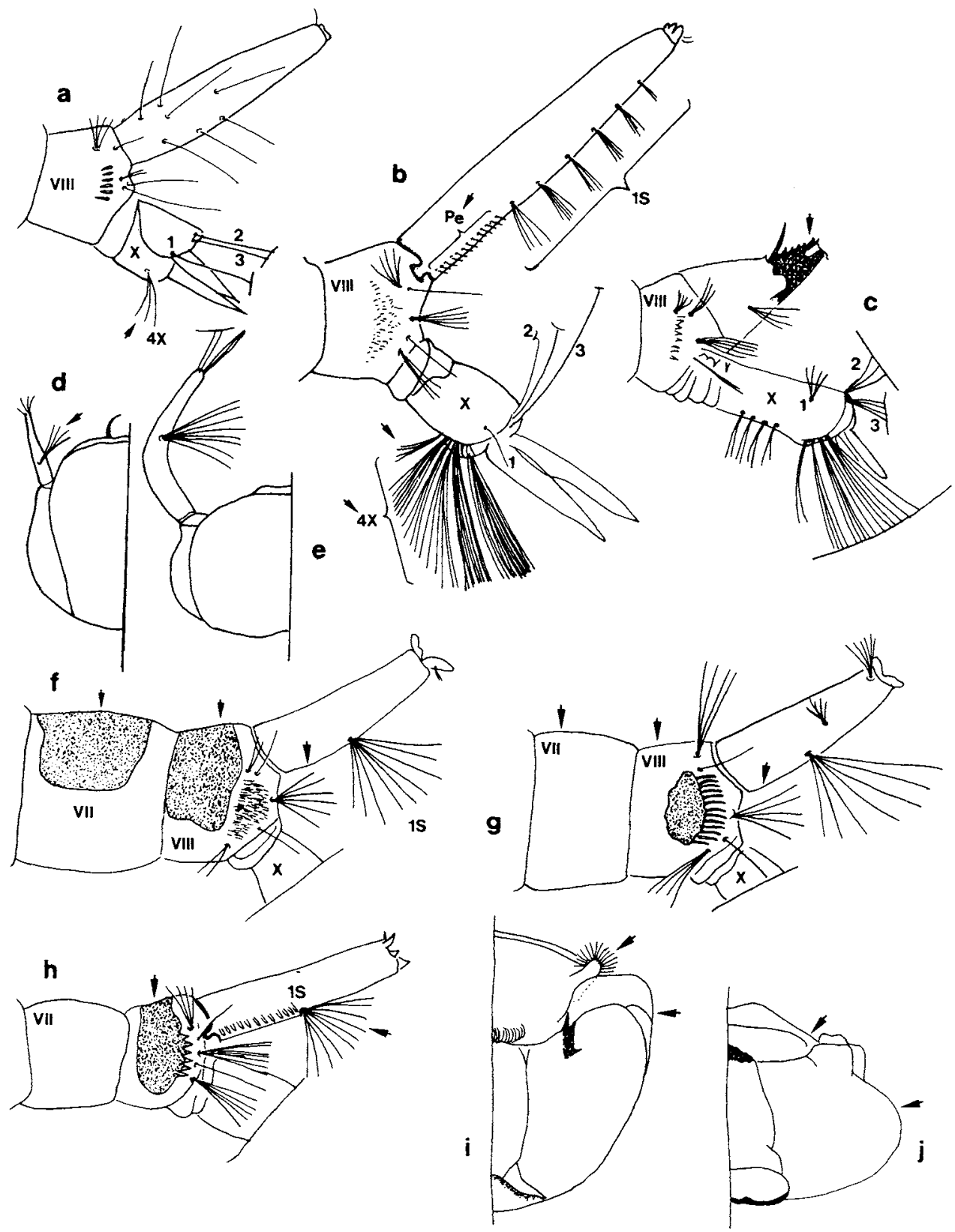

FIG. 24: Aspectos da mofologia externa de Culicinae larva. Ilustrações referidas na chave dicotômica. a-c: abdome, vista lateral dos segmentos VIII e X e do sifão; $d$, e: cabeça, vista dorsal; f-h: abdome, vista leteral dos segmentos VII, VIII e X e do sifão; i, j: cabeça, vista ventral. 
3. Pécten sinfonal ausente (Fig. 24.f, g) 4

Pécten sinfonal presente, representado pelo menos por um par de espinhos (Figs. 24.b; 25.c, d). 5

4. Presença de larga placa tergal quitinosa, nos segmentos VII e VIII (Fig. 24.f); antena simples, muito mais curta que a cabeça (Fig. 24.d)

Orthopodomyia

(Orthopodomyiini)

Ausência de placa tergal nos segmentos VII e VIII (Fig. 24.g); antena fortemente curvada e mais longa que a cabeça (Fig. 24.e) Aedeomyia

(Aedeomyiini)

5. Cerda 1-S composta por mais de um par de pêlos (Fig. 24.b) 6 (Culicini)

Cerda 1-S composta por apenas um par de pêlos, às vezes muito pequenos (Fig. 25.c, d).

6. Base da mandíbula com processo desenvolvido, de extremidade romba e pilosa, projetando-se lateralmente; cabeça alargada próximo ao nível da antena, por uma dobra lateral (Fig. 24.i) Deinocerites

Base da mandíbula sem tal lobo; cabeça mais larga na metade caudal (Fig. 24.j) Culex

7. Cerdas 5 e 6-C grossas, bem quitinizadas, com aparência espiniforme, simples e aciculada nas margens (Fig. 25.a); segmento VIII com placa quitinizada desenvolvida, em cuja margem distal estão fixadas as escamas do pecten (Fig. 24.h) Uranotaenia (Uranotaenini)

Cerdas 5 e 6-C normais, finas, semelhantes às demais cerdas da cabeça (Fig. 25.b); segmento VIII sem placa quitinizada ou apresentando-a pouco evidente (Fig. 25.c, d) 8 (Aedini)

8. Sela do segmento $X$ bem desenvolvida, circundando todo o segmento como um anel, sendo atravessada, ventralmente, pela cerda 4- $X$, que se estende pelo menos até a sua metade basal; cerda $1-S$ geralmente simples ou pouco desenvolvida (Fig. 25.c) 
Sela do segmento $X$ menos desenvolvida, muitas vezes incompleta, deixando de circundar $O$ segmento à maneira de um anel e a cerda 4- $X$ achando-se inserida fora dela e restrita à região distal do segmento (Fig. 25.d)

Para a identificação genérica das larvas da tribo Sabethini pode-se utilizar as chaves propostas por Belkin et al., (1970) e Zavortink (1979).

Chaves para identificar as tribos e gêneros através da genitália masculina e da pupa podem ser encontradas em Belkin et al., (1970).
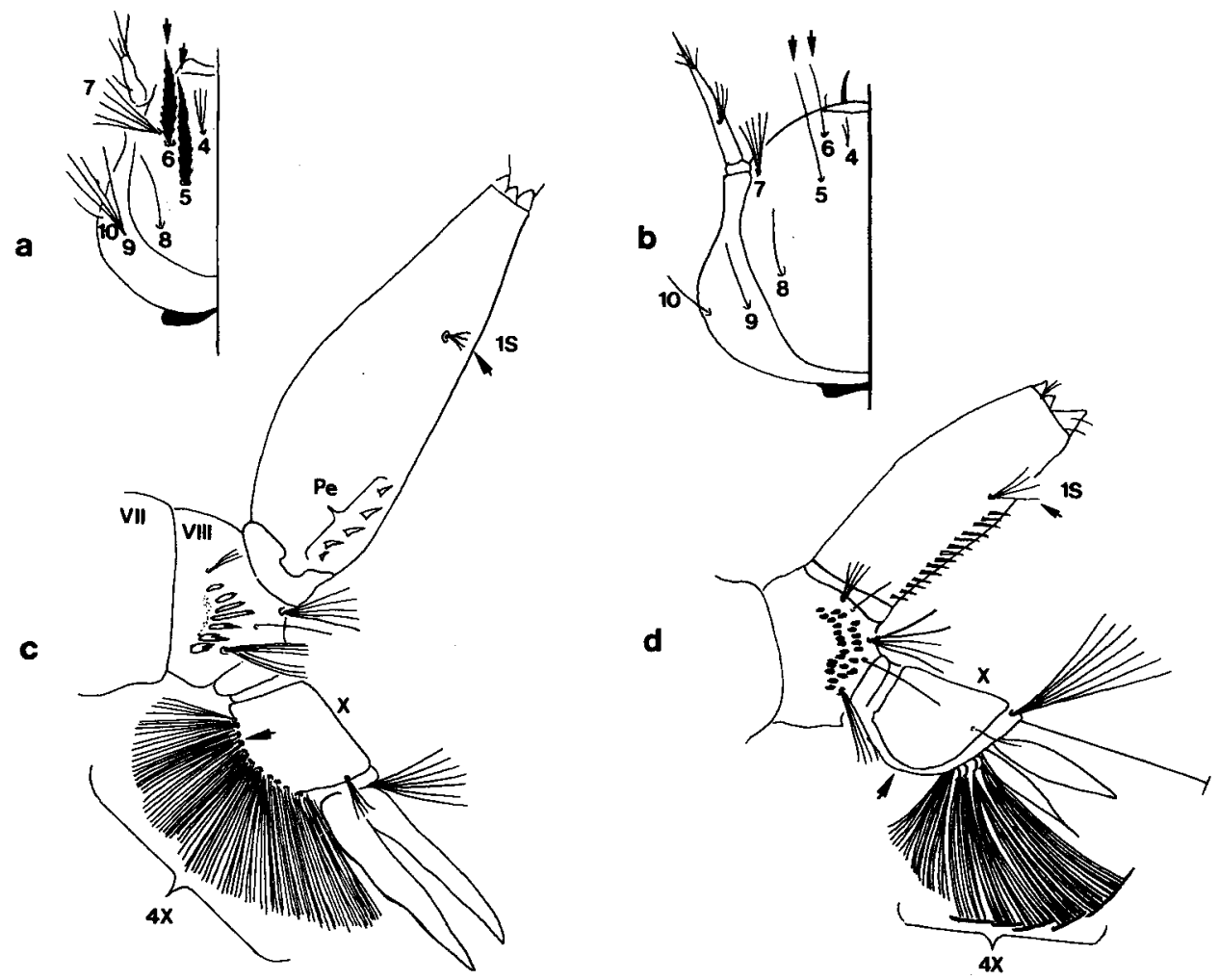

Fig. 25: Aspectos da morfologia externa de Culicinae larva. Ilustrações referidas na chave dicotômica. a, b: cabeça, vista dorsal; c, d: abdome, vista lateral dos segmentos VIII, $\mathrm{X} e$ do sifão. 


\section{Tribo Aedeomyiini}

Há apenas um gênero nesta tribo e somente uma de suas espécies ocorre no Brasil e Américas:

\section{Aedeomyia squamipennis Theobald, 1901}

Trata-se de um mosquito pequeno, de aspecto felpudo e de colorido branco, pardo e preto, com algumas áreas amareladas. Os segmentos flagelares da antena são curtos, semelhantes a pequenas esferas. Os fêmures médio e posterior são dotados de um tufo de escamas salientes.

Suas formas imaturas são encontradas principalmente em coleções líquidas de tamanho médio ou grande, geralmente profundas, ricas em vegetação flutuante, como lagoas, bolsões de rios e igarapés e corixos. As larvas são capazes de permanecer sem renovar o ar na superfície durante períodos mais longos do que a maioria dos Culicinae.

Esta espécie é conhecidamente ornitófila. Não ataca o homem e outros mamíferos, mas pode ser capturada em armadilhas que usam luz como isca. Pratica o hematofagismo durante a noite, procurando as aves nos seus abrigos, inclusive nos galinheiros (Gabaldon et al., 1977b).

Foi incriminada como vetor de plasmódios de aves, de espécies desconhecidas do parasito pertencente aos subgêneros Giovannolaia e Novyella, na Venezuela (Gabaldon et al., 1977a).

Até agora não se conhece relação desta espécie com a veiculação de doenças que atingem o homem.

\section{Tribo Aedini}

Inclui três gêneros que ocorrem no Brasil: Aedes, Psorophora e Haemagogus.

Nesta tribo estão agrupadas dezenas de espécies cujos hábitos diferem bastante entre si. Contudo, boa parte dos Aedini é de hábito diurno ou crepuscular vespertino; suas espécies são muito agressivas e oportunistas, depositam seus ovos, isoladamente, diretamente sobre a superfície líquida ou em um substrato úmido, próximo à água ou em local inundável.

Várias espécies dos gêneros Aedes, Psorophora e Haemagogus produzem ovos resistentes à dessecação. Neste caso, após o período necessário para o desenvolvimento embrionário inicial, passado em ambiente ainda úmido, os ovos podem permanecer mais de um ano em locais secos. As larvas nascem facilmente, com um posterior contato dos ovos com a água.

Devido a essa característica, os Aedini têm os criadouros transitórios, que são condicionados diretamente pelas chuvas, como os seus preferenciais. Decorrente disso, sua população de alados sofre flutuação grande e abrupta de densidade no ciclo anual, isto é, seu ciclo anual é controlado pela quantidade de chuvas e pela temperatura ambiente. Seus criadouros, representados pelas poças 
d'água e pelos recipientes naturais e artificiais, são preenchidos quase somente na época chuvosa. Com o aumento da precipitação pluviométrica simultânea às ascensões térmicas que precedem a chegada do verão e que se mantém durante esta estação, estes criadouros passam a ser ciclicamente reabastecidos de água, desencadeando o processo de eclosão dos ovos depositados ali meses antes. Assim, as chuvas influenciam positivamente na densidade desses insetos, elevando-a enormemente nessas ocasiōes.

Por outro lado, durante o período de menor precipitação e temperaturas mais baixas, algumas espécies de Aedini podem ser quase completamente ausentes ou manter-se em níveis de densidade bem baixos.

A transitoriedade dos criadouros utilizados pelos Aedini impõe um desenvolvimento rápido das suas fases larvares e da pupa, pois o ciclo inteiro deve ser completado antes da evaporação total do líquido do criadouro.

Muitos dos Aedini (e também vários elementos de outras tribos) são aqui estudados por serem transmissores de arboviroses.

Arboviroses ( $\mathrm{Ar}=$ arthropod + bo= borne + virusis) são enfermidades infecciosas causadas por vírus (arbovírus) que se multiplicam nos tecidos de artrópodes hematófagos, sendo transmitidos, através da picada, para vertebrados suscetíveis, nestes produzindo viremia capaz de infectar um novo hospedeiro invertebrado.

Há cerca de 180 diferentes tipos de arbovírus no Brasil, quase todos de ocorrência na Amazônia, dos quais apenas cerca de $20 \%$ são considerados patogênicos para o homem. Somente quatro deles têm verdadeira importância epidemiológica por produzirem epidemias e tornarem os indivíduos infectados incapazes, temporariamente, para suas atividades normais ou, até, causarem casos fatais. As quatro arboviroses a que nos referimos são: Febre amarela, Dengue, Oropouche e Mayaro. Acrescenta-se a essas, as arboviroses causadoras de encefalites, particularmente o Rocio, responsável por epidemias no Sudeste do Brasil, na década de 1970.

Resumidamente, o ciclo dos arbovírus tem muitos pontos em comum. Inclue e/ou depende de três hospedeiros: o vertebrado não humano, o invertebrado e o homem.

Os hospedeiros vertebrados não humanos são responsáveis por permitir a produção de uma viremia capaz de infectar o inseto hematófago vetor. Contudo, esse hospedeiro não é um bom reservatório para o vírus, pois os níveis de partículas virais circulantes baixam bruscamente à medida que anticorpos específicos vão sendo formados e, progressivamente, os insetos que se alimentarem no seu sangue vão deixando de se infectar. Os vertebrados suscetíveis aos arbovírus estão entre os mamíferos (roedores, preguiças, marsupiais, macacos etc.) e aves, as quais, devido a sua capacidade de deslocamento pelo vôo, espalham passivamente os arbovírus, muitas vezes de um continente para o outro, nos períodos de migração.

O artrópode é o real reservatório dos arbovírus, além de desempenhar o papel de transmissor. Uma vez infectado, o artrópode permanece infectado e infectante pelo resto de sua vida, sendo incapaz de controlar a invasão do vírus 
em todas as partes de seu corpo. Assim, os ovários também podem ser atingidos e , não raramente, certa proporção dos ovos produzirá adultos que já nascerão naturalmente infectados com o virus (transmissão transovariana ou vertical). Se ainda considerarmos a propriedade dos ovos de muitos Aedini de resistirem a dessecação por longos períodos e permanecerem latentes até uma nova estação chuvosa, percebemos como tais insetos são importantes na manutençăo desses arbovírus na natureza.

O homem pode ser um hospedeiro vertebrado apenas acidental para o arbovirus. Com raras exceções, como na febre amarela urbana e dengue, em que o homem é o único hospedeiro vertebrado nas epidemias, as arboviroses independem de sua presença. Entretanto, no caso de algumas arboviroses que invadem as vilas e cidades, como as duas supracitadas e o Oropouche, as modificaçōes produzidas pelo homem no ambiente favorecem a proliferação dos artrópodes vetores (ampliando os criadouros e abrigos para os insetos) e a transmissão do agente etiológico.

Uma das formas de classificar as arboviroses é com base na sua evolução clínica e patológica. Desta forma são classificadas em : 1) Febril (Ex.: Oropouche); 2) Febril e exantemática (Ex.: Mayaro); 3) Febril e hemorrágica (Ex.: febre amarela e dengue) e 4) Encefalites (Ex.: Rocio, Enc. de St. Louis, Enc.Equina Oeste).

Dadas algumas características principais dos Aedini em geral, podemos iniciar o estudo de algumas de suas espécies que têm importância epidemiológica.

\section{GENERO AEDES MEIGEN, 1818}

Os Aedes são caracterizados pelo que já foi exposto na chave dicotômica para identificação dos gêneros de Culicinae e também por possuírem o final do abdome freqüentemente afilado, pontudo, ou seja, os ultimos segmentos estão parcialmente inbricados uns nos outros de modo telescópico, com as cercas salientes. Suas larvas têm sifão curto, quase cônico, geralmente bem escurecido, com a cerda 1-S constituída de apenas um par de pêlos, embora quase sempre múltiplos e desenvolvidos; a sela do segmento $X$ é geralmente incompleta.

Os seguintes subgêneros de Aedes ocorrem no Brasil (Kingh \& Stone, 1978): Ochlerotatus, Stegomyia, Howardina e Protomacleaya.

As espécies de Aedes de importância epidemiológica estão agrupadas nos subgêneros Stegomyia e Ochlerotatus, para os quais daremos atenção.

A seguir, apresentamos uma chave dicotômica para a identificação das espécies de Aedes que ocorrem no Brasil, adaptadas das propostas por Forattini (1965a) e Berlin (1969). Nela há referências a ilustrações para facilitar na identificação das espécies mais comuns ou de maior importância médica. 
Chave para a identificação das espécies de Aedes que ocorrem no Brasil: fêmeas.

1. Unhas tarsais femininas denteadas, pelo menos as anteriores e as médias (Fig. 26.a).

Unhas tarsais femininas lisas, pelo menos as anteriores e as médias (Fig. 26.b)

2. Clípeo com dois tufos de escamas branco-prateadas

(Fig. 26.c); escudo ornamentado com escamas branco-prateadas formando desenho em forma de lira (Fig. 26.d).

Clípeo nu (Fig. 26.f), ou com escamas claras, mas não prateadas

3. Segmento abdominal VIII estreito e retrátil, de modo que não se apresenta visível ao exame externo; cercas longas e estreitas (Fig. 26.h) 4

Segmento abdominal VIII um tanto largo, pouco retrátil, apresentando-se visível ao exame externo, ocasião em que se nota que é comprimido em sentido lateral e dotado de revestimento de escamas; cercas curtas (Fig. 26.i)

4. Asa com escamas de tonalidades claras e escuras, mesmo que apenas na porção basal das veias anteriores.

Asa com todas as escamas de tonalidade escura

5. Asa com escamas claras e escuras misturadas. albifasciatus Asa com escamas claras limitadas, em maior ou menor extensão, às veias anteriores

6. Asa com escamas claras dispostas em pequena extensão, na base da veia Costa e da veia $R$ pennai Asa com escamas claras dispostas na veias Costa $e$ $R$, cobrindo a metade ou mais da extensão dessas veias, a partir da base; tegumento torácico amarelado, com manchas marrons 
106 PRINCIPAIS MOSQUTTOS DE IMPORTÂNCIA SANITÁRIA
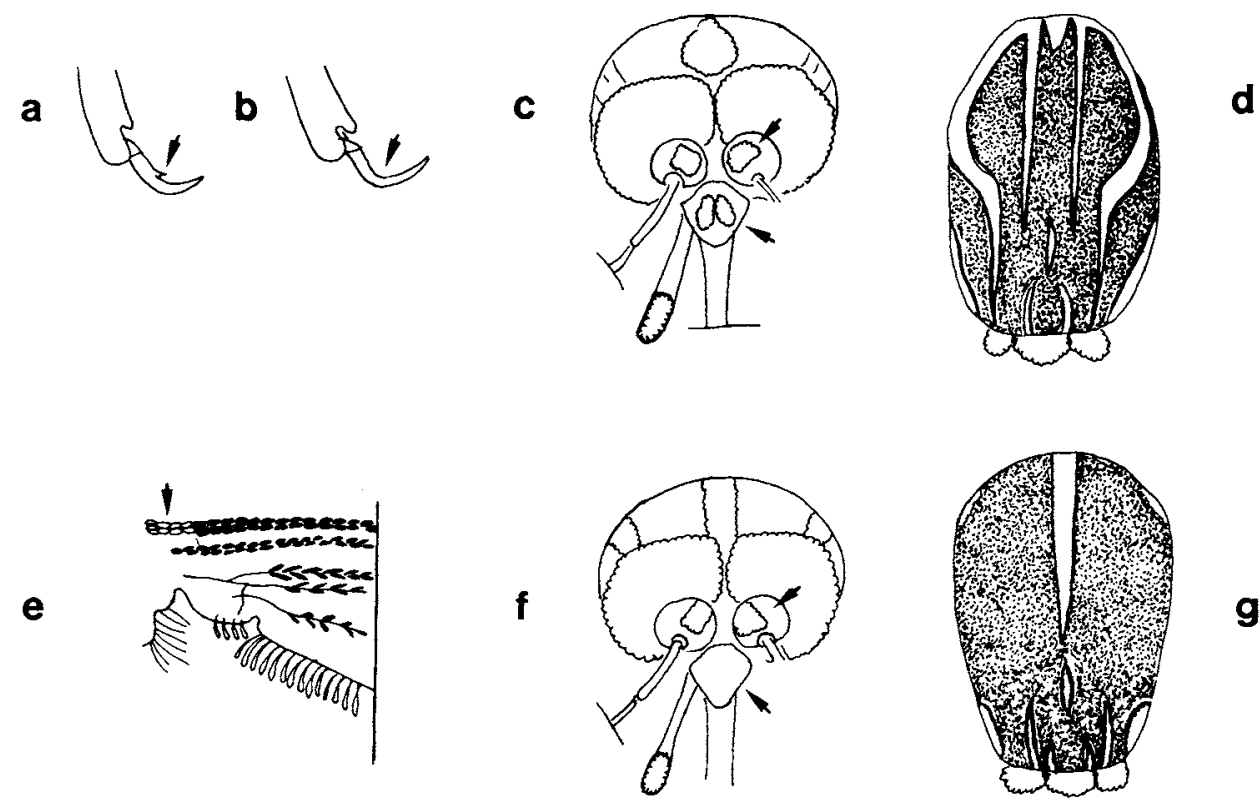

9

h

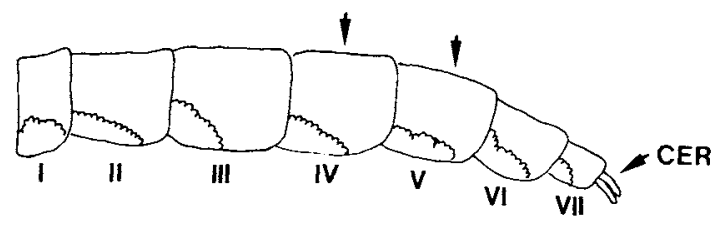

i
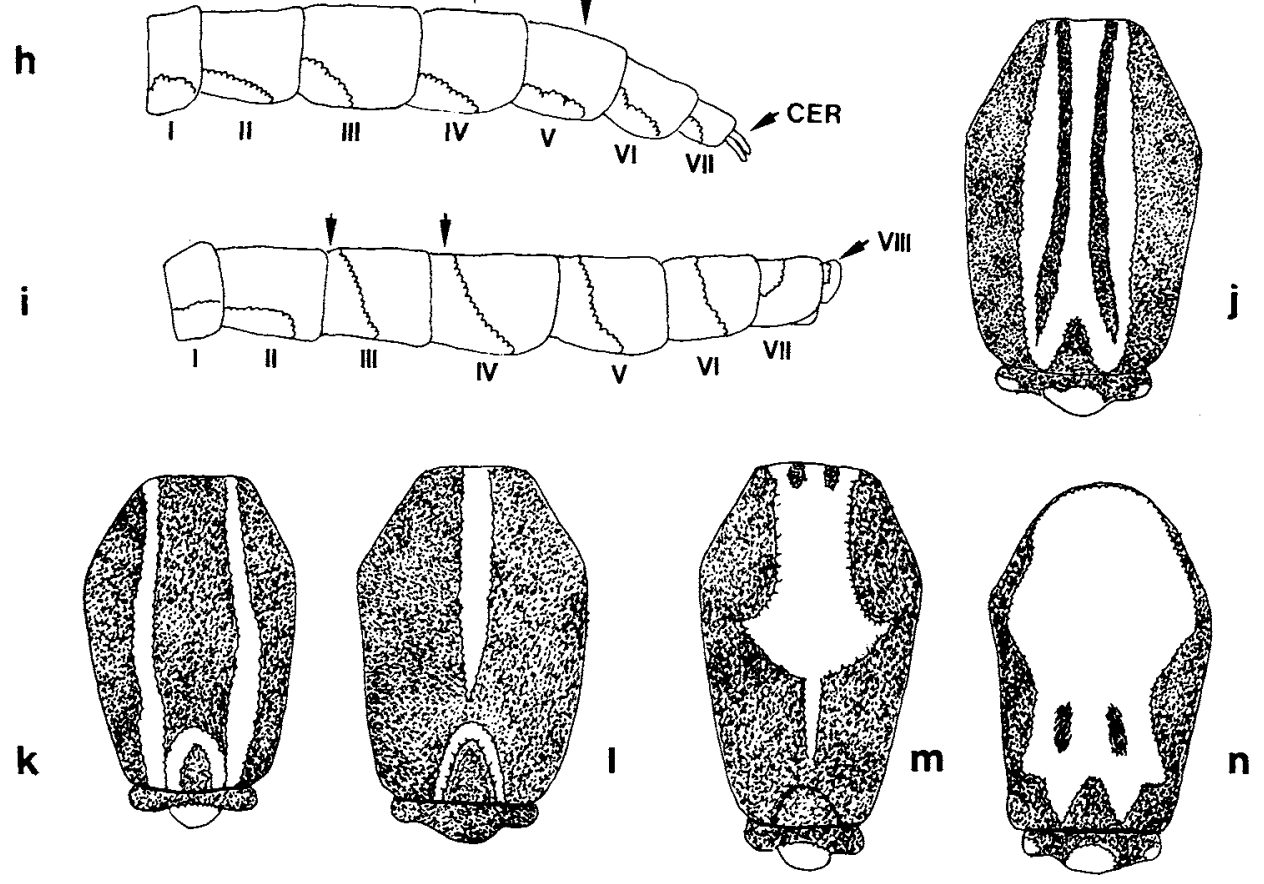
7. Tegumento do escudo com duas manchas marrom-escuras, bem acentuadas, colocadas póstero-lateralmente, ao nível das raízes alares; mesocatepisteno ligeiramente pigmentado $e$ mesanepímero sem pigmentação escura evidente stigmaticus

Tegumento do escudo com duas manchas marrom póstero-laterais, pouco evidentes; faixa pigmentada de tonalidade marrom-escura, abrangendo a metade inferior do mesanepimero e o mesocatepisteno. fulvus

8. Tarsos com anel branco nos artículos; probóscide com anel claro mediano. taeniorhynchus

Tarsos escuros, sem anel claro

9. Tegumento torácico amarelo ............................................................................. 10

Tegumento torácico escuro, marrom ou enegrecido ....................................... 11

10. Escudo com numerosas escamas amareladas esparsas, sem formarem mancha definida hortator

Escudo com duas faixas de escamas escuras e duas manchas de tonalidade semelhantes póstero-laterais, próximas às raízes alares perventor

11. Tergitos abdominais, pelo menos alguns deles, com faixa clara basal (Fig. 26.i)

Tergitos abdominais sem faixas claras basais, somente com áreas basolaterais desta tonalidade (Fig. 26.h)

12. Escudo com desenho constituído por manchas de escamas claras, brancas ou prateadas

1 Fig. 26: Aspectos da morfologia externa de Aedes adulto. a, b: unha tarsal; c, f: cabeça, vista frontal com destaque para os toros e o clípeo; e: asa, destaque para porção basal da veia Costa; $\mathrm{d}, \mathrm{g}, \mathrm{j}-\mathrm{n}$ : mesonoto (escudo + escutelo), vista dorsal; $h$, i: abdome, vista lateral dos segmentos (I-VIII) (cercas - CER). Em $i$ aparece faixa clara de escamas que abrange toda a base do tergito, enquanto em $h$ aparece apenas manchas claras baso-laterais que não se unem no dorso do tergito para formar a faixa. 
Escudo com desenho constituído por faixas de escamas claras, esbranquiçadas, amarelas ou douradas (uma faixa mediana estreita e duas paramedianas) (Fig. 26.j) crinifer

13. Fêmur e tíbia com anel claro no ápice lepidus Fêmur e tíbia sem anel claro no ápice jacobinae

14. Escudo ornamentado com escamas claras que se dispõem formando faixas longitudinais ou manchas, ou seja, formando desenho (Fig. 26.k-n).

Escudo sem tais ornamentações, totalmente coberto de escamas escuras

15. Escudo com escamas claras dispostas em faixa longitudinal ou mancha, sempre medianas (Fig. 26.1-n)

Escudo com escamas claras dispostas em duas faixas longitudinais paramedianas (Fig. 26..k)

16. Escudo com escamas claras dispostas em faixa mediana longitudinal (Fig. 26.1)

Escudo com escamas claras dispostas em ampla mancha ocupando boa parte da porção anterior (Fig. 26.m, n)

17. Lobo mediano do escutelo com escamas douradas ou escuras, bronzeadas. serratus e aenigmaticus

Lobo mediano do escutelo com escamas brancas ou prateadas; occipício com faixa central de escamas brancas estreitas limitada, bilateralmente, por conjunto de escamas largas e escuras hastatus, serratus e oligopistus

18. Mancha do escudo formada por escamas claras, de contornos irregulares, angulosos, lembrando a forma de uma pele de mamífero estirada (Fig. 26.m) rhyacophilus Mancha do escudo formada por escamas claras, de contornos regulares, arredondados (Fig. 26.n) scapularis 
19. Asa com escamas claras e escuras; as claras

limitadas à base da veias Costa e/ou R (Fig. 26.e)

Asa apenas com escamas escuras; tarsos com

marcação clara; escudo com mancha de escamas

esbranquiçadas ocupando quase os $2 / 3$ anteriores

fluviatilis

20. Escudo com as manchas de escamas claras

ântero-laterais, alongadas e estendendo-se

lateralmente, até a raiz alar do lado correspondente;

presença de escamas brancas esparsas pela superfície

do escudo, particularmente na área pré-escutelar.

terrens

Escudo com as manchas de escamas claras

ântero-laterais, largas, aproximadas entre si na linha

média, e não se prolongando, lateralmente, até a raiz

alar do lado correspondente; poucas ou raras

escamas brancas esparsas pela superfície do escudo

e área pré-escutelar

argyrothorax

21. Escudo coberto por escamas bronzeadas ou escuras

e apresentando linha(s) longitudinal(ais) de escamas

claras

Escudo com ampla mancha anterior formada por

escamas douradas; porção posterior do escudo com

escamas escuras, podendo apresentar escamas

douradas misturadas àquelas

fulvithorax

22. Toro com tufo de escamas prateadas, internamente

(Fig. 26.f); escudo com uma faixa longitudinal de

escamas prateadas (Fig. 26.g)

albopictus

Toro sem escamas; escudo ornamentado

diferentemente

23. Parte anterior do escudo com uma linha central (acrostical) de escamas douradas e estreitas e outras

paralelas (dorso centrais internas e externas),

paramedianas ou laterais, de escamas da mesma tonalidade

arborealis

Parte central anterior do escudo com apenas a linha

central (acrostical) de escamas douradas e estreitas,

podendo haver linhas paralelas laterais

(dorso-centrais externas), posteriormente, de

escamas da mesma tonalidade 
A seguir, acha-se uma chave para identificação da fase larvária das espécies de Aedes que ocorrem no Brasil, adaptada daquelas propostas por Forattini (1965a) e Berlin (1969). Note-se que algumas espécies incluídas na chave para adultos não aparecem nesta chave. Isto ocorre porque suas formas larvares ou são pouco conhecidas ou desconhecidas.

Chave para a identificação das espécies de Aedes que ocorrem no Brasil: larvas.

1. Sela do lobo anal completa (Fig. 27.a-c)............................................................... 2

Sela do lobo anal incompleta (Figs. 27.h; 28.a, d) .......................................... 10

2. Pecten sifonal, com os últimos espinhos destacados

da fileira constituída pelos demais fulvus

Pecten sifonal, com todos os espinhos regularmente espaçados entre si (Fig. 27.a-c, h).

3. Cerda 1-S implantada dentro do pecten; cerda 5-C longa, simples; cerda 6-C mais curta, tripla ou múltipla pennai

Cerda 1-S implantada além do pecten (Fig. 27.a-c, h) 4

4. Papilas anais pigmentadas, muito longas, 8 vezes ou mais o comprimento da sela 5

Papilas anais não pigmentadas, relativamente curtas, ou seja, menos de 8 vezes o comprimento da sela (Figs. 27.a-c, h; 28.a, d)

5. Cerda $2-X$ simples oligopistus

Cerda 2-X múltipla, geralmente com 7 ramos hastatus

FIG. 27: Aspectos da morfologia externa de Aedes larva. Ilustrações referidas na chave dicotômica. a-c: abdome, vista lateral dos segmentos VIII e $\mathrm{X}$ e do sifão [papilas anais=Pa, pecten sifonal=Pe, pecten ou pente do segmento VIII=PVIII, sela do lobo anal-Sa]; $\mathrm{d}$, e: dorsomento; f: escama do pente do segmento VIII de Ae.aegypti; g: cabeça (de Ae. aegypi), vista dorsal; h: abdome, vista lateral dos segmentos VIII e X e do sifão de Ae. aeg!́pti. 

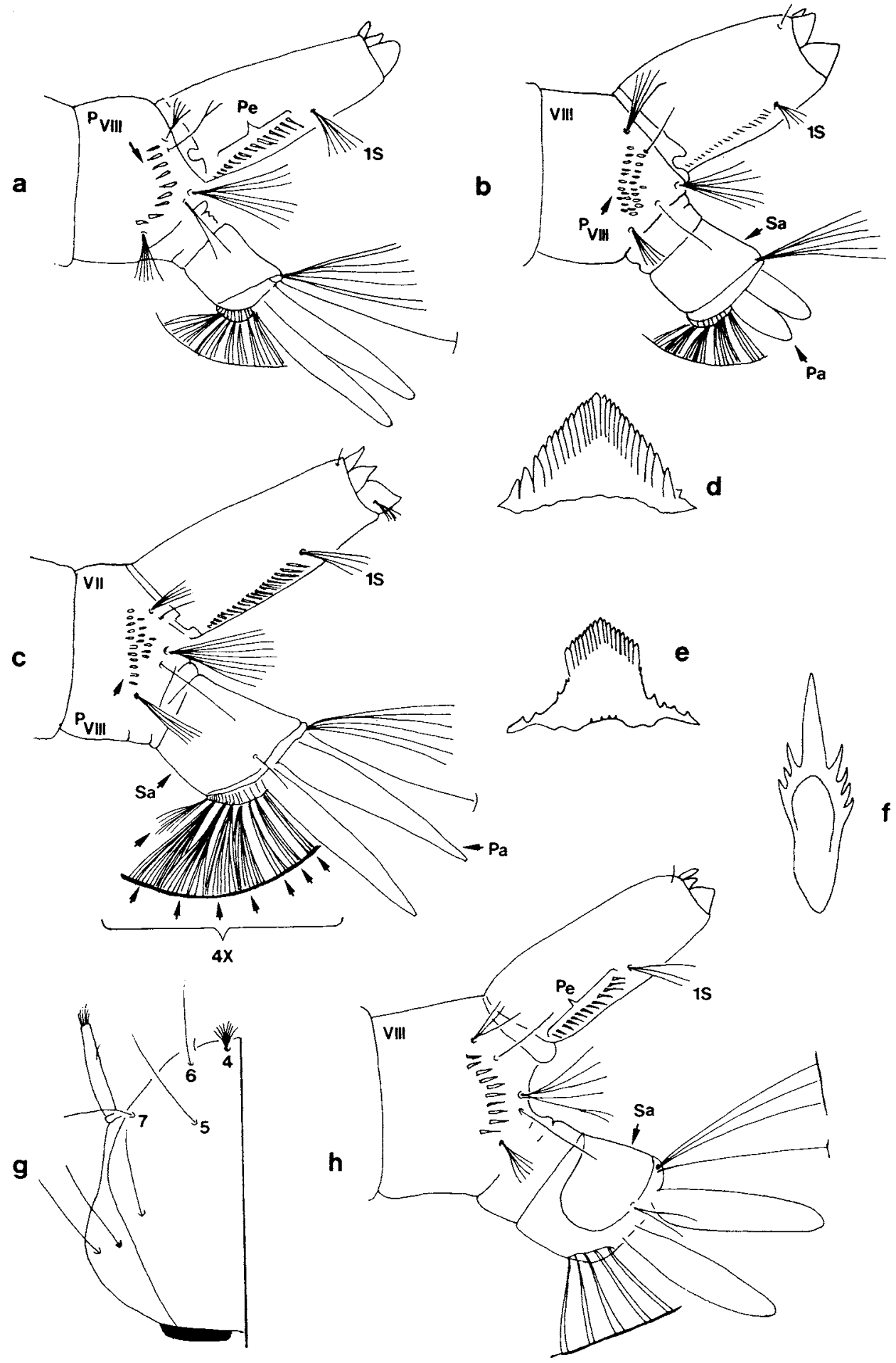
6. Pente de escamas do segmento VIII constituído por uma fileira de poucos elementos (Fig. 27.a). serratus

Pente de escamas do segmento VIII constituido por maior número de elementos que se dispõem em conjunto (Fig. 27.b, c)

7. Sifão com tufos acessórios dorsais, além de existir a cerda 1-S. crinifer

Sifão somente com a cerda 1-S, sem tufos acessorios (Fig. 27.b, c). 8

8. Papilas anais mais curtas que a sela do lobo anal (Fig. 27.b.) taeniorhynchus

Papilas anais, tão ou mais longas do que a sela do lobo anal (Fig. 27.c)

9. Dorsomento com aspecto geral triangular (Fig. 27.d);

cerda 4-X composta de 8 pares de tufos (Fig. 27.c) scapularis

Dorsomento com a porção apical de aspecto pentagonal (Fig. 27.e); cerda 4-X composta de 7 pares de tufos rhyachophilus

10. Pecten com os últimos espinhos destacados da fileira constituída pelos demais; os espinhos distais lisos albifasciatus

Pecten com todos os espinhos regularmente espaçados entre si (Fig. 27.h; 28.a, d)

11. Cerdas 5-7-C, simples (Fig. 27.g);. [escamas do pente do segmento VIII com um espinho longo mediano, com dentes bilaterais (Fig. 27.f)] aegypti Cerdas 5-7-C, ou pelo menos a 7-C, duplas, triplas ou múltiplas (Fig. 28.b)

12. Pente do segmento VIII formado por escamas dispostas em uma só fileira (Fig. 28.a, d).

Pente do segmento VIII formado por escamas dispostas em conjunto (Fig. 27.b, c) 

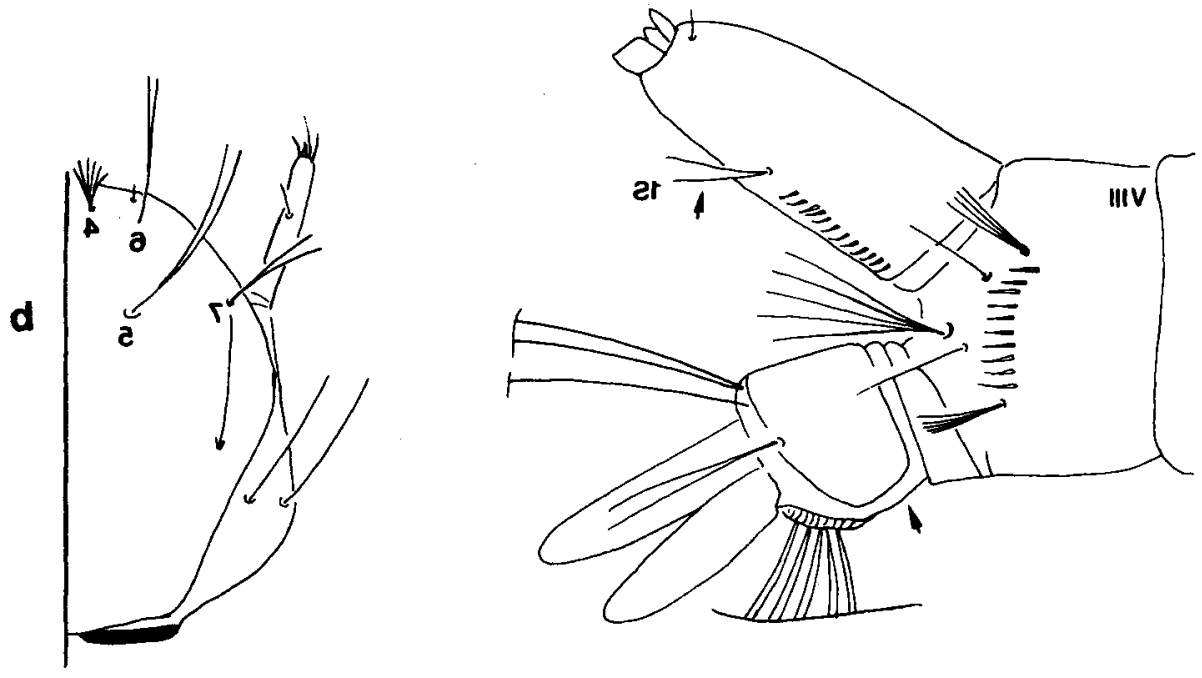

$\mathbf{6}$
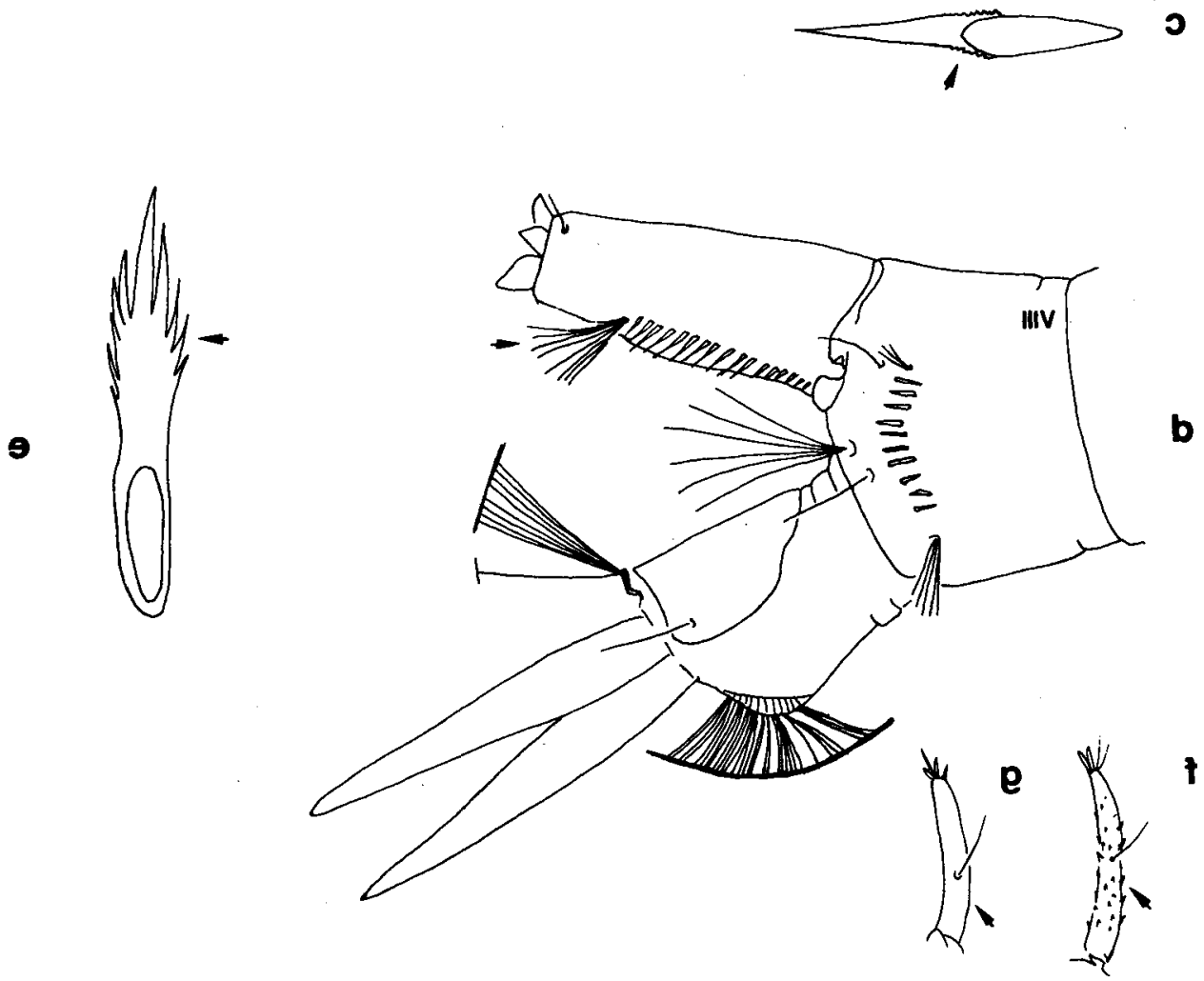

Fig. 28: Aspectos da morfologia externa de Aedes larva. Ilustraçōes referidas na chave dicotômica; a, d: abdome, vista lateral dos segmentos VIII e X e do sifão; b: cabeça (de $A e$. albopictus), vista dorsal; c, e: escamas do pente do segmento VIII; f, g: antena. 
13. Cerda 1-S com 2 a 4 ramos (Fig. 28.a); escamas do pente do segmento VIII com aspecto de um único espinho longo, sem dentes laterais, apenas com pequena serrilha ou franja nas bases laterais (Fig. 28.c) albopictus

Cerda 1-S múltipla (Fig. 28.d); escamas do pente do segmento VIII com dentes quitinizados, bilaterais, que aumentam de tamanho, gradativamente, da base ao ápice (Fig. 28.e) lepidus

14. Antena lisa (Fig. 28.g) .............................................................................. 15 Antena espiculosa (Fig. 28.f) ................................................................... 17

15. Cerda 1-S múltipla argyrothorax Cerda $1-5$ com 2 a 4 ramos 16

16. Cerda 1-X dupla, lisa; cerda 11-C dupla; maioria dos espinhos do pecten sem dentículos basais arborealis Cerda 1-X geralmente tripla (varia de 2 a 7 ramos), aciculada; cerda 11-C tripla ou múltipla; todos os espinhos do pecten com dentículos basais. fulvithorax

17. Papilas anais de comprimento desigual, um par mais longo que o outro hortator

Papilas anais de comprimento mais ou menos equivalente para os dois pares

18. Cerda 1-X múltipla; cerda 5-C com 2 ou 3 ramos; cerda 6-C simples ou dupla terrens

Cerda 1-X simples ou dupla; cerda 5-C múltipla; cerda 6-C dupla fluviatilis

Para identificação de machos de Aedes, a partir de sua genitália, recomendamos empregar as chaves apresentadas por Forattini (1965a), Berlin (1969) e Schick (1970).

\section{Subgênero Stegomyia Theobald, 1901}

É um subgênero do Velho Mundo, particularmente da região etiópica, mas duas de suas espécies invadiram países fora de sua distribuição zoogeográfica original, incluindo o Brasil: Aedes (Stegomyia) aegypti e Aedes (Stegomyia) albopictus. 
Os Stegomyia adultos apresentam tórax enegrecido, freqüentemente ornamentado com manchas, faixas ou desenhos de escamas claras, geralmente branco-prateadas. Tais ornamentações se prolongam até o escutelo, onde as escamas claras geralmente predominam. As pernas são de aspecto listrado, pois a maioria dos segmentos tarsais, e muitas vezes o fêmur e a tíbia apresentam manchas brancas. A probóscide tem comprimento semelhante ao do fêmur anterior. As garras tarsais podem ser denteadas ou simples (lisas). A caracterização da genitália masculina e das formas imaturas pode ser obtida nas publicações de Hopkins (1936), Edwards (1941) e Huang (1972).

Os Aedes do subgênero Stegomyia desenvolvem-se em criadouros do tipo recipiente, tanto naturais (buracos em árvore, bromélias, internódios de bambu) quanto artificiais (representados por uma enorme variedade). Nesses locais os ovos são depositados fora da água, nas paredes internas e úmidas dos recipientes onde, após rápido desenvolvimento embrionário, são capazes de se manter viáveis por longos períodos, mesmo em condiçōes desfavoráveis de dessecação. As fêmeas são hematófagas vorazes e atacam durante o dia.

\section{Aedes aegypti Linnaeus, 1762}

Distribuição geografica. Embora oriundo do Velho Mundo (provavelmente da região etiópica, tendo sido originalmente descrito do Egito), acompanhou o homem em sua longa e ininterrupta migração pelo mundo, e permaneceu onde as alterações antrópicas propiciaram a sua proliferação. Hoje é considerado um mosquito cosmopolita, com ocorrência nas regiōes tropicais e subtropicais, compreendidas principalmente entre os paralelos (latitudes) $45^{\circ} \mathrm{N} \mathrm{e}$ $35^{\circ} \mathrm{S}$ ou mesmo fora desses limites, mas dentro das zonas isotermais de $20^{\circ} \mathrm{C}$.

Por ter sido disseminada principalmente de forma passiva pelo homem, esta espécie tem, muitas vezes, a sua distribuição geográfica descontínua: está presente nos locais para onde o homem a levou em embarcações, trens, automóveis, aviōes etc., e onde encontrou condições favoráveis para a sua multiplicação.

Embora Ae. aegypti possa ser encontrado longe de aglomerados humanos, em algumas áreas do Velho Mundo, em nosso país está restrito às vilas e cidades, sempre ligado ao peridomicílio e ao domicílio humano. Nas cidades brasileiras é encontrado nos locais de maior concentração humana e raramente em ambientes semi-silvestres ou onde a população humana é mais rarefeita.

Ae. aegypti foi introduzido no Brasil durante o período colonial, provavelmente na época do tráfego de escravos. Devido a sua importância como vetor da febre amarela, foi intensamente combatido em nosso território, tendo sido considerado erradicado em 1955. Contudo, países vizinhos como as Guianas e a Venezuela, dentre outros sul-americanos, como também os Estados Unidos da América, Cuba e vários países centro-americanos, não o erradicaram. Esse descuido provocou a reinvasão do Brasil pelo Ae. aegypti, em Belém do Pará, em 1967 (aí erradicado ainda na década de 1960), no Estado do Rio de Janeiro, provavelmente em 1977 e em Roraima no início da década de 1980. Hoje ocorre nos Estados litorâneos, do Maranhão ao Paraná, e da Região Centro-Oeste, além de Minas Gerais e Tocantins. 
Biologia. Seus criadouros preferenciais são os recipientes artificiais, tanto os abandonados pelo homem a céu aberto e preenchidos pelas águas das chuvas, como aqueles utilizados para armazenar água para uso doméstico. Esses criadouros são representados principalmente por pneus, latas, vidros, cacos de garrafa, pratos de vasos e xaxins e vasos de cemitério, no primeiro caso. Caixas d'água, tonéis, latōes e cisternas destapadas ou mal tapadas, ou mesmo os lagos artificiais, piscinas e aquários abandonados correspondem aos criadouros mais comuns, no segundo caso.

Em todos os criadouros supracitados, há proliferação de Ae. aegypti com a condição de que a água armazenada seja limpa, isto é, não turva, pobre em matéria orgânica em decomposição e em sais, e acumulada em locais (recipientes) principalmente sombreados e de fundo ou paredes escuras.

Tanto no Brasil quanto em outros países americanos o Ae. aegypti tem sido surpreendido criando-se em recipientes naturais como bromélias usadas com fim ornamental, buracos em árvore, escavação em rocha e bambu. Escavações no solo com fundo argiloso ou forrada de cimento ou pedra também são empregadas por esse mosquito para se criar. Tais encontros são muito raros em comparação com os criadouros preferenciais.

Como já dissemos para os Aedini em geral, Ae. aegypti também tem sua densidade populacional diretamente influenciada pela presença de chuvas. Embora possa manter uma população considerável durante as estações menos chuvosas, a custa dos criadouros semipermanentes e independentes das chuvas (caixas d'água, cisternas, latões etc.). É durante a estação chuvosa que sua população realmente alcança níveis elevados e de importância para fins de transmissão de patógenos.

As fêmeas de Ae. aegypti restringem seus hábitos hematófagos aos horários diurnos. Seus picos de maior atividade acham-se, geralmente, situados no amanhecer e pouco antes do crepúsculo vespertino, mas ataca o homem, e por vezes animais domésticos, a qualquer hora do dia. À noite, embora raramente, podem ser oportunistas, atacando o homem se este se aproxima de seu abrigo. O hábito diurno também é o demonstrado pelos machos, que seguem as fêmeas em seus abrigos domiciliares e peridomiciliares, para efetuarem a cópula e obter substâncias açucaradas.

Ae. aegypti é dotado de certo ecletismo em relação à fonte sanguínea para alimentação, mas o homem é sua principal vítima. Ataca animais das mais diversas categorias, desde que estejam próximos a seus criadouros e abrigos. Como, no Brasil, tais locais acham-se quase sempre no domicilio ou em sua imediata vizinhança, é o homem o hospedeiro mais procurado por este Aedini. $O$ homem é atacado principalmente nos pés e na parte inferior das pernas.

A longa associação do Ae. aegypti com a espécie humana parece tê-lo dotado de certa habilidade para escapar de ser morto por sua vítima durante o repasto sanguíneo. Assim é que, se o hospedeiro produz movimento, mesmo que suave, uma fêmea de Ae. aegypti prontamente o abandona, voltando a atacá-lo ou procurando outra vítima, depois de cessado o iminente perigo de ser atingida. Esta peculiaridade tem grande importância, pois uma só fêmea de Ae. aegyp- 
ti infectada pode, enquanto procura alimentar-se satisfatoriamente de sangue, produzir várias alimentações curtas em diferentes hospedeiros e disseminar o dengue ou a febre amarela.

Ae. aegypti e $C x$. quinquefasciatus são os mais domésticos mosquitos que ocorrem no Brasil, freqüentando o domicilio humano para obter sangue a maneira de um rodízio: este à noite e aquele de dia, embora ambos ali permaneçam em repouso, antes e após a sua alimentação.

A domesticidade deste Aedini é ressaltada pelo fato de que ambos os sexos são encontrados, em proporções semelhantes, dentro das casas e nos abrigos peridomiciliares. Logo após a emergência dos adultos, ambos os sexos se dirigem e/ou permanecem no domicílio ou peridomicílio e ali copulam, obtêm seus alimentos e desovam.

Relação com a febre amarela e o dengue. No Brasil, Ae. aegypti foi o unico vetor conhecido de febre amarela urbana e é também o único transmissor do dengue, em nossos dias.

A febre amarela, embora causada por um mesmo tipo de arbovírus (um Flavivirus), pode se manifestar, epidemiologicamente, de duas formas: Febre Amarela Silvestre e Febre Amarela Urbana. A forma silvestre é veiculada na floresta por mosquitos silvestres que picam animais suscetíveis ao vírus, especialmente macacos, transmitindo a enfermidade entre eles, sendo o homem um hospedeiro acidental. Por outro lado, a forma urbana da febre amarela é veiculada dentro das cidades e vilas, de homem para homem, pelo Ae. aegypti.

Devido a sua elevada endofilia, antropofilia e susceptibilidade ao vírus da febre amarela, o Ae. aegypti é um excelente vetor para a forma urbana da doença. É considerado o vetor clássico desta arbovirose.

A febre amarela urbana foi considerada extinta do país desde 1942, quando ocorreram seus últimos casos, em Sena Madureira, no Acre. Sua última epidemia na América, produzida a custa do Ae. aegypti, aconteceu em 1929. Por outro lado, pouco após sua reintrodução no Brasil, o Ae. aegypti iniciou uma progressiva e alarmante propagação do dengue.

O dengue é também causaảo por um Flavivirus. Porém, há 4 soro-tipos desse vírus: D 1, D 2, D 3 e D 4. Epidemias ou surtos de dengue foram desencadeados e mantidos a custa do Ae. aegypti em Roraima (Dengue 1 e 4); no Rio de Janeiro e Alagoas (Dengue 1 e 2), Ceará, Minas Gerais, Bahia, Pernambuco, São Paulo e Mato Grosso do Sul (Dengue 1) e Tocantins (Dengue 2). Tais epidemias ocorreram inicialmente apenas nos meses chuvosos, mas em algumas localidades o dengue chegou a se tornar endêmico (ex.: cidades do Estado do Rio de Janeiro, como a capital, Niterói, São Gonçalo, Nova Iguaçu etc.)

A epidemiologia do dengue no Brasil, pelo aspecto entomológico, em tudo se assemelha à da febre amarela urbana, e sua atual distribuição coincide com a do Ae. aegypti, seu único vetor natural comprovado.

Tanto na febre amarela urbana como no dengue há transmissão transovariana do vírus, de maneira que, variável percentual das fêmeas filhas de um espécime infectado, nasce já infectado. 


\section{Aedes albopictus Skuse, 1894}

Distribuição geográfica. Ae. albopictus é, como o Ae. aegypti, um mosquito estrangeiro. Ocorre naturalmente em áreas de clima temperado e tropical na Região Oriental, na Austrália, na Nova Guiné, nas Ilhas Mariane, Havaianas, Bonin, Reunion e Mauricius, em Madagascar, no Oeste do Irã e Japão. Foi originalmente descrito da Índia.

Invadiu o continente americano recentemente (1985), ocupando localidades ao sul dos Estados Unidos. Foi pela primeira vez encontrado no Brasil, em maio de 1986, nos Estados de Minas Gerais e Rio de Janeiro. Invadiu, progressivamente, outros Estados vizinhos como Espírito Santo e São Paulo. Deve ter entrado no Brasil através de portos no Espírito Santo e se interiorizado, via estrada de ferro, no vale do rio Doce (transporte de minério de ferro). A população desse mosquito ora existente no Brasil parece ser oriunda do Japão (para onde é exportada grande quantidade de ferro através daqueles portos) e apresenta diferenças biológicas em relação à cepa invasora da América do Norte.

Sua distribuição, no Brasil, ainda é associada à presença do homem, utilizando, como o Ae. aegypti, os criadouros propiciados pela atividade humana. Contudo, é um mosquito que se espalha com facilidade no ambierte rural, semisilvestre e silvestre, não dependendo dos locais de grande concentração humana, como o Ae. aegypti. É comumente encontrado, por isso, nas áreas onde a população humana é escassa, nas bocas de matas e plantações, onde o Ae. aegypti é ausente ou muito raro.

É, porém, mais tolerante às temperaturas mais baixas (ex.: norte da Ásia), enquanto o Ae. aegypti as evita.

Biologia. Ae. albopictus cria-se em recipientes naturais e artificiais. Compete com o Ae. aegypti dentro das vilas e cidades, aproveitando os mesmos tipos de criadouros já assinalados para este outro mosquito. Acredita-se, até, que o resultado dessa competição seja favorável ao Ae. albopictus, pois a densidade deste costuma aumentar enquanto a do Ae. aegypti diminui, gradativamente, após certo tempo de coexistência.

Ae. albopictus emprega com grande freqüência criadouros naturais como os internódios de bambu, buracos em árvore e cascas de frutas. Recipientes artificiais abandonados nas florestas e em plantações são focos muito utilizados por esse mosquito.

As fêmeas de Ae. albopictus freqüentemente depositam seus ovos aos poucos, em vários recipientes diferentes, o que facilita a dispersão da espécie.

Nos demais aspectos da biologia é muito semelhante ao Ae. aegypti. Ressaltamos, resumidamente, que Ae. albopictus é diurno, muito eclético quanto ao hospedeiro, sendo o homem e as aves suas vítimas mais freqüentes; comparece muito ao domicílio humano, mas é muito mais comum no peridomicílio; seus ovos são resistentes à dessecação e sua densidade é diretamente influenciada pelas chuvas.

Relação com a transmissão de arbovírus. Ae. albopictus é vetor natural do dengue em áreas rurais, suburbanas e urbanas da Ásia, com comprovada ocor- 
rência de transmissão transovariana do vírus. Lá, também é transmissor da Encefalite Japonesa.

No Brasil, Ae. albopictus ainda não foi incriminado como vetor do dengue (ou outro arbovírus), pois a sua distribuição e abundância não coincidem com as da doença e em apenas uma ocasião larvas desse mosquito foram achadas naturalmente infectadas com o vírus (Dengue tipo 1) em nosso país (Serufo et al., 1993). Entretanto, populações de Ae. albopictus existentes no Brasil demonstraram, experimentalmente, susceptibilidade e capacidade de veicular horizontalmente os 4 sorotipos do vírus do dengue e de transmitir verticalmente (transovarianamente) os sorotipos 1 e 4 desse vírus. As mesmas populações não foram transmissoras eficientes do vírus da febre amarela, embora capazes de infectarse com esse microrganismo, experimentalmente (Miller \& Ballinger, 1988; Mitchell \& Miller, 1990).

Devemos ressaltar que este mosquito pode tornar-se uma "ponte" entre os ciclos silvestre e urbano da febre amarela e de outros arbovírus no Brasil, considerando-se sua facilidade de freqüentar, igualmente, os ambientes silvestres, rurais, suburbanos e urbanos.

\section{Subgênero Ochlerotatus Lynch-Arribalzaga, 1894}

É o subgênero com maior número de espécies no Brasil e demais países Neotropicais.

São mosquitos cujo escudo é geralmente ornamentado com escamas estreitas de mais de uma tonalidade, possuindo linhas ou manchas e apresentando grupo de escamas, geralmente claras, nas pleuras.

As fêmeas desse subgênero são muito vorazes, insistentes em obter sangue e oportunistas. Aumentam muito sua atividade no crepúsculo vespertino, mas atacam, indiscriminadamente, de dia ou à noite. Parte das espécies tem ovos resistentes à dessecação.

A maioria das espécies de Ochlerotatus é eurigâmica (como Ae. scapularis e Ae.teaniorhynchus), mas algumas são estenogâmicas (como Ae. fluviatilis).

Seus criadouros são principalmente os de caráter transitório, no solo. Algumas espécies criam-se em recipientes naturais ou artificiais.

\section{Aedes scapularis (Rondani, 1848)}

Distribuição geográfica. É um mosquito essencialmente neotropical, sendo a América do Sul oriental a região onde é realmente abundante. Existe do norte da Argentina até a Colômbia e em Trinidad e Tobago. Na América Central, ocorre da Costa Rica ao México, nas Grandes Antilhas, Bahamas e Sul dos E.U.A. (Texas) (Arnell, 1976). Existe em todos os Estados do Brasil.

É muito comum nas matas secundárias, plantações e outros ambientes parcialmente modificados pelo homem e nas baixadas.

Biologia. As formas imaturas de Ae. scapularis se desenvolvem apenas em criadouros no solo, de caráter transitório, nunca em recipientes. Prefere as cole- 
ções de caráter natural como poças d'água e alagados, embora seja também encontrado nas artificiais, como valas de drenagem, impressð̃es de pneus e de patas de animais no solo. Tais criadouros são geralmente de pouca profundidade e muita luminosidade, podendo ser destituídos de vegetação. Porém, freqüentemente apresentam alguma vegetação emergente (gramíneas), que os tornam parcialmente sombreados.

Sua densidade está direta e positivamente influenciada pelas chuvas. E um mosquito de ocorrência em todo o ano, mas com densidade muito aumentada na estação quente-chuvosa (Lourenço-de-Oliveira et al., 1985; Forattini et al., 1986). Sua densidade aumenta bruscamente neste periodo, quando este Aedini torna-se uma praga e causa grande perturbação aos animais e ao homem.

Ae. scapularis ataca em maior numero no crepúsculo vespertino, mas tem atividade hematofágica intensa durante toda a noite ou mesmo a qualquer hora do dia. Sua densidade aumenta, consideravelmente, no final da tarde, pois os momentos precedentes ao pôr-do-sol parecem ser os mais apreciados por este Aedini para obter sangue em suas vítimas (Lourenço-de-Oliveira \& Silva, 1985; Forattini \& Gomes, 1988).

É também eclético e oportunista quanto ao hospedeiro. Ataca o homem com muita voracidade, mas tem grande tendência a atacar mamiferos de grande porte com maior intensidade. Quando se compara a quantidade de Ae. scapularis atacando bovinos e eqüinos com a obtida em homem, numa mesma ocasião, verifica-se que aqueles são muito mais sugados que este (Lourenço-de-Oliveira \& Heyden, 1986; Forattini et al., 1987).

É muito mais freqüente nas matas secundárias e nos ambientes alterados extradomiciliares (até mesmo no peridomicílio) que no domicilio humano, embora penetre neste ambiente, em números consideráveis, em certas localidades do Sudeste brasileiro, especialmente nas épocas de maior densidade populacional.

Relação com a transmissão de patógenos. Ae. scapularis foi considerado como suspeito de transmitir a encefalite Rocio, que causou epidemias no sudeste de São Paulo, em 1975-6. Durante as epidemias, este Aedini foi um dos mosquitos mais abundantes nas áreas atingidas, mas não foi achado naturalmente infectado com o vírus, embora tenha demonstrado ser eficiente vetor em condições de laboratório (Forattini et al., 1978a, b; Mitchell \& Forattini, 1984; Mitchell et al., 1986).

Ainda na região Sudeste, Ae. scapularis foi encontrado infectado com Flavivirus não identificado, porém diferente daqueles da febre amarela e dengue (Castro et al., 1991). Outros arbovírus têm sido isolados desse mosquito em condições naturais, no norte do Brasil e em Trinidad (Forattini, 1965a, Arnell, 1976; Hervé et al., 1986).

Ae. scapularis foi considerado vetor local da W. bancrofti, em inquéritos realizados em Santa Catarina, na década de 1950. Exemplares desta espécie foram encontrados albergando larvas infectantes atribuídas a esse helminto, mas tratava-se de uma área de elevada endemicidade desta filariose mantida à custa do seu vetor primário o Cx. quinquefasciatus. Ae. scapularis deve ter se infectado apenas de forma ocasional e deve ser um vetor muito extraordinário da doença (Rachou, 1956). 


\section{Aedes taeniorhynchus Wiedemann, 1821}

Distribuição geográfica. Ae. taeniorhynchus é uma espécie característica do litoral e das áreas de solos salgados das Américas, apresentando, no Brasil, distribuição semelhante a do An.aquasalis. Contudo, estende seu território de Massachusetts, nos E.U.A. até o Sul do Brasil (Costa Atlântica) e da Califórnia até o Peru (Costa Pacífica), além das Antilhas e Illhas Galápagos.

Adultos dessa espécie podem ser encontrados em locais distantes dos seus criadouros costeiros devido à sua grande capacidade de vố, que pode ultrapassar $50 \mathrm{~km}$.

Biologia. Seus criadouros são sempre as coleções líquidas no solo, de caráter transitório e dotadas de certo grau de salinidade, como poças d'água, valas de drenagem, alagadiços e charcos de água salobra. Seus ovos, bastante resistentes à dessecação, são colocados em locais úmidos de solo sujeito a alagamento.

Em virtude da grande transitoriedade de seus criadouros, sua população de alados aparece quase somente no verão de chuvas torrenciais (Forattini, 1965a, Lourenço-de-Oliveira et al., 1985).

Ae. taeniorhynchus é mosquito muito eclético, voraz e oportunista. Ataca o homem, aves e répteis com agressividade, mas parece ter grande predileção pelo sangue de mamiferos de grande porte, como eqüídeos.

É exófilo e crepuscular. Pica indiscriminadamente de dia e à noite, mas aumenta sua atividade hematofágica nos crepúsculos, principalmente no vespertino, e entra nas casas s 6 ocasionalmente e quando a sua densidade acha-se muito alta.

Relação com a transmissão de patógenos. Ae. taeniorhynchus tem sido encontrado naturalmente infectado com diferentes arbovírus, causadores de encefalites ou não, em vários locais da América Latina, inclusive no Brasil e nos E.U.A., como resume Forattini (1965a). Além disso é considerado vetor potencial da $D$. immitis, filarídeo de canídeos e felinos, que, raramente, atinge o homem (Nyar, 1985).

\section{Outras espécies de Ochlerotatus}

Outras espécies de Ochlerotatus encontradas no Brasil têm bem menos importância que as duas supracitadas, pois não são tão comuns e/ou têm pouca ou nenhuma relação com a transmissão de patógenos ao homem. Trataremos de algumas delas a seguir.

Ae. fulvus (Wiedemann, 1828), aedino grande e de aspecto geral amarelo, cria-se em depressões no solo de caráter transitório, mas também é encontrado em alagados perenes, com vegetação; ataca o homem com grande agressividade a qualquer hora do dia ou da noite, mas com nítida preferência crepuscular. Contudo, é mais zoofílico que antropofilico e essencialmente silvestre, podendo picar indiscriminadamente aos níveis do solo e da copa da floresta. Raramente se aproxima das casas. Foi encontrado naturalmente infectado com vírus da febre amarela, na Serra do Navio, Amapá e vírus Melao, em Belém do Pará (Forattini, 1965; Hervé et al., 1986). 
Em condições de laboratório, dois mosquitos deste subgênero têm sido empregados como vetores do Plasmodium gallinaceum, protozoário causador de malária em galinhas, que só ocorre naturalmente no Velho Mundo, mas é um dos mais utilizados como modelo experimental de malária, em todos os continentes. São eles: Ae. fluviatilis (Lutz, 1904) e Ae. lepidus Cerqueira \& Paraense, 1945. Ambos mosquitos se infectam muito bem com esse plasmódio e produzem considerável quantidade de esporozoítos infectantes. Ae. fluviatilis é capaz de ainda infectar-se experimentalmente com o virus da febre amarela e Dirofilaria immitis. Ambos os mosquitos freqüentam o ambiente peridomiciliar com certa assiduidade, sendo ali encontradas criando-se em recipientes artificiais, muitas vezes em associação com Ae. aegypti ou $C x$. quinquefasciatus. São mosquitos comuns em locais silvestres, semi-silvestres, suburbanos, bem como urbanos. Ae. fluviatilis cria-se principalmente em escavações em rochas que acumulam águas das chuvas, quando em ambiente silvestre. Os ovos de Ae. fluviatilis não resistem à dessecação por muitos dias (no máximo 30, em laboratório). Ae. lepi$d u s$ é considerado por alguns autores como mosquito zoofílico (ornitófilo), mas também ataca o homem. Ae. fluviatilis é capaz de sugar mamíferos, aves e répteis, mostrando preferência pelo homem em condições experimentais.

Ae. serratus (Theobald, 1901) é heterogêneo quanto ao aspecto do adulto (ver chave), podendo ser um complexo de espécies, compondo o grupo Serratus. Contudo, parece que os verdadeiros Ae. serratus sempre apresentam faixa clara longitudinal no escudo em ambos os sexos. As fêmeas do Grupo Serratus quase ou completamente destituídas da faixa podem, no Brasil, corresponderem a Ae. nubilus (Theobald, 1903) (Belkin et al., 1970; Forattini et al., 1993). É um Ochlerotatus típico nos aspectos morfológicos e biológicos, muito se assemelhando seus hábitos com o descrito para Ae. scapularis. E eclético quanto ao hospedeiro, porém com preferência por grandes mamíferos; ataca ao pôr-do-sol com maior intensidade e prefere as matas secundárias ao domicílio ou a sua imediata vizinhança (Forattini, 1965a; Forattini et al., 1986; Forattini et al., 1987). Suspeitase que este mosquito tenha algum papel na transmissão de arbovírus e algumas vezes tem sido surpreendido naturalmente infectado com tais agentes (Forattini, 1965a; Hervé et al., 1986).

Ae. albifasciatus (Macquart, 1838) é um aedino comum no Cone Sul de nosso continente, onde tem importância por representar uma praga na época de sua maior reprodução (verão chuvoso), atacando animais e o homem com grande voracidade. Cria-se em depressões em terrenos planos, temporárias, com ou sem vegetação. É muitas vezes encontrado no peridomicílio e nas casas; é zoofílico e preferencialmente crepuscular.

Dados sobre a biologia e a distribuição dos demais Aedes que ocorrem no Brasil podem ser obtidos em Forattini (1965a).

\section{GENERO PSOROPHORA ROBINEAU-DESVOIDY, 1827}

Os Psorophora são mosquitos robustos, restritos a Novo Mundo, figurando nesse gênero os maiores mosquitos hematófagos do Brasil. São extremamente vorazes e sua picada é muito dolorosa. 
Atacam preponderantemente de dia, mas o crepúsculo vespertino também estimula sua hematofagia.

São essencialmente exófilos, zoofílicos e oportunistas e podem atacar o homem, muitas vezes em grande número.

Seus ovos são muito resistentes à dessecação, sendo depositados, isoladamente, fora do líquido. Um de seus subgêneros tem larvas predadoras, mas todas as espécies desse gênero criam-se em coleções líquidas no solo, de preferência aquelas de caráter temporário.

As fêmeas têm abdome de ápice pontudo e cercas salientes, possuem cerdas pré-espiraculares e, na maio:ia dos casos, o clípeo apresenta-se intumescido.

São agrupados em 3 subgêneros, cujas espécies ocorrentes no Brasil (Knight \& Stone, 1978) podem ser identificadas conforme a chave abaixo (adaptada de Forattini, 1965a; Guedes \& Souza, 1964).

\section{Chave para a identificação das espécies de Psorophora que ocorrem no Brasil: fêmeas.}

1. Escudo revestido com escamas, mas com áreas longitudinais escamadas; pernas, principalmente as posteriores, com revestimento de escamas e cerdas eretas e salientes, dando aspecto hirsuto a esses apêndices; mosquitos de porte avantajado

Escudo revestido totalmente com escamas, mais ou menos uniformemente distribuídas e sem áreas glabras determinadas; pernas sem aspecto particularmente hirsuto; mosquitos de porte médio ou pequeno

2. Tarsos escuros, sem marcação clara

Tarsos com marcação clara, pelo menos em alguns segmentos posteriores

3. Pleuras com escamas abundantes e uniformemente esparsas cilipes

Pleuras com escamas pouco numerosas e distribuídas em conjuntos 
4. Escudo com a faixa central de escamas constituída de elementos claros, dourados; [asa somente com escamas escuras] ciliata

Escudo com a faixa central de escamas constituída por elementos escuros, bronzeados; [tergitos abdominais cobertos predominantemente com escamas brancas] holmbergii

5. Garras tarsais femininas denteadas, pelo menos as anteriores e médias; mosquitos escuros, geralmente dotados de colorido metálico

Garras tarsais femininas simples, pelo menos as anteriores e médias; mosquitos acinzentados, sem colorido.

6. Tarsos completamente escuros; escudo com escamas amarelo-ouro lateralmente e faixa central escura lanei Tarsos posteriores marcados de branco.

7. Tarso posterior $V$ com marcação escura variável 8 Tarso posterior $\mathrm{V}$ totalmente branco 10

8. Escudo com uma faixa larga de escamas escuras no meio, delimitada por faixa de escamas amareladas, lateralmente; tarso posterior IV inteiramente branco; tarso $\mathrm{V}$, geralmente, com as extremidades escuras $\mathrm{e}$ o meio branco. albigenu

Escudo com escamas claras regularmente esparsas ou com a porção mediana com escamas amareladas a bronzeadas; tarso posterior IV com ápice escuro; tarso posterior $\mathrm{V}$ com marcação diferente

9. Escudo com escamas bronzeadas no centro e amareladas ou esbranquiçadas dos lados; tarso posterior $\mathrm{V}$ inteiramente escuro ou apresentando, raramente, escamas claras num dos lados discrucians

Escudo uniformemente coberto por escamas de cor zinabre; tarso posterior V totalmente branco, com apenas o ápice escuro 
10. Escudo com uma distinta faixa de escamas escuras no meio.

Escudo ornamentado por uma mistura de escamas claras e escuras ferox

11. Articulação fêmuro-tibial com mancha prateada. 12 Articulação fêmuro-tibial sem mancha prateada circunflava

12. Probóscide mais longa que o fêmur anterior 14 Probóscide igual ou mais curta que o fêmur anterior

13. Toro marrom, sem escamas lutzi Toro amarelado, com escamas na face interna forceps

14. Cerdas da margem lateral posterior do escudo, isto é, para trás da asa, escuras; depressão pré-escutelar e lobo mediano do escutelo com escamas escuras; escamas laterais do escudo de tonalidade esbranquiçada albipes

Cerdas da margem lateral posterior do escudo, para trás da asa, alaranjadas

15. Tergitos abdominais com faixa apical de escamas brancas (II a V) amazônica

Tergitos abdominais com faixa apical de escamas amarelas albigenu

16. Asa com escamas totalmente escuras. 17 Asa com escamas claras e escuras

17. Tergitos abdominais com áreas claras ápico-laterais, que não se unem na porção mediana do segmento cingulata Tergitos abdominais com faixas claras completas, apicalmente. dimidiata 
18. Tarso posterior I escuro e somente com anel branco

basal; [asa com uma só mancha escura nítida,

localizada na base da veia $R_{4+5}$ (terceira

longitudinal)]

varinervis

Tarso posterior I possuindo, além da marcação clara

basal, um anel mediano da mesma tonalidade;

[tergitos abdominais escuros, com áreas claras

triangulares, apicomedianas]

confinnis

As larvas de Psorophora não foram suficientemente estudadas, motivo pelo qual não se dispõe de chave dicotômica para a sua identificação.

As espécies desse gênero não são tão importantes, como as de Aedes $e$ Haemagogus, no que diz respeito à transmissão de patógenos, mas algumas têm relação com a veiculação de arbovírus, como veremos a seguir.

\section{Subgênero Psorophora Robineau-Desvoidy, 1827}

São mosquitos muito grandes, com corpo ornamentado de escamas claras e escuras, mas sem reflexos metálicos ou violáceos. As larvas são predadoras vorazes, alimentando-se de larvas de outros mosquitos e de outros invertebrados aquáticos, ou agindo como canibais.

Criam-se em depósitos no solo e têm ovos muito resistentes à dessecação, o que faz seu ciclo anual depender das chuvas que inundam os terrenos baixos.

São exófagos, exófilos, zoofilicos e preferem os mamíferos de grande porte. Podem atacar o homem e animais domésticos com agressividade, muitas vezes impedindo as atividades extradomiciliares durante sua época de maior densidade.

As espécies mais encontradas nas baixadas e áreas rurais brasileiras são Ps. ciliata (Fabricius, 1794) e Ps.cilipes (Fabricius, 1805). São mosquitos enormes, de picada muito dolorosa, que atacam principalmente ao pôr-do-sol, mas que podem picar de dia ou à noite. homem.

Não parecem estar comprometidas com a transmissão de patógenos ao

\section{Subgênero Grabhamia Theobald, 1903}

São mosquitos de porte médio, de coloração fosca, escura e acinzentada. Apresentam anel claro mediano na probóscide e na extremidade distal do fêmur posterior.

Criam-se em coleções líquidas no solo, naturais ou artificiais, transitórias e localizadas geralmente em descampados, tais como valas de drenagem, impressões de pneus e de patas de animais, poças d'água, com ou sem vegetação (Forattini, 1965a; Lourenço-de-Oliveira et al., 1986). Picam ao crepúsculo vespertino e à noite e são muito zoofílicos e exófilos. 
No Brasil, as espécies mais comuns, que devido ao seu oportunisme em relação à hematofagia, produzem problemas para o trabalho do homem, no descampado, em certas áreas, são Ps. confinnis (Lynch Arribalzaga, 1891) e Ps. cingulata (Fabricius, 1805).

Espécies deste subgênero não têm sido incriminadas como transmissoras de patógenos ao homem, mas são, muitas vezes, verdadeiras pragas. Alguns dados sobre a biologia podem ser obtidos em Forattini (1965a) e Lourenço-de-Oliveira \& Heyden (1986).

\section{Subgênero Janthinosoma Lynch Arribalzaga, 1891}

São mosquitos de pequeno e médio porte, com abdome, e muitas vezes também o tórax, escameado de violáceo, com freqüente reflexo metálico. Isto é, são os mais coloridos e bonitos dos Psorophora.

Criam-se em depressões rasas no solo, transitórias e geralmente ricas em vegetação emergente, ou sombreadas à custa das copas das árvores, quando se localizam dentro das matas. São exemplos desses criadouros os alagados, os charcos e os banhados.

As fêmeas são vorazes hematófagas, oportunistas, zoofilicas, exófilas e de hábitos preferencialmente diurnos, mas podem picar ao crepúsculo e à noite, mas com menor intensidade.

\section{Psorophora ferox Von Humboldt, 1819}

Distribuição geográfica. Ocorre do norte da Argentina e Uruguai até o sul do Canadá, incluindo as Antilhas.

É uma espécie muito ligada à existência de florestas, mas sai facilmente das matas e capões para picar o homem e animais, nos descampados.

Biologia. Seus hábitos são aqueles citados para o subgênero. Ressaltamos suas preferências pelas horas mais claras do dia, pelas matas de planície e capões e pelo sangue dos mamíferos grandes. Ataca o homem dentro das florestas, próximo a elas ou no peridomicilio, com grande agressividade, quando sua densidade acha-se elevada, o que coincide com a época de abundância de chuvas .

Dados mais detalhados sobre a sua biologia podem ser encontrados em Forattini (1965a) e Forattini et al. (1986; 1987; 1993).

Relação com a transmissão de patógenos. Ps. ferox tem sido encontrada naturalmente infectada com arbovírus causadores de encefalites, como Encefalite Venezuelana, no norte da América do Sul, incluindo a Amazônia brasileira, Encefalite Saint Louis, em Trinidad e Rocio e no litoral de São Paulo. Outros arbovírus foram detectados em Ps. ferox, como vírus Ilhéus e Mayaro. Mais detalhes sobre esses encontros e sua importância epidemiologica podem ser obtidos em Forattini (1965a), Lopes et al.(1981), Mitchell et al.(1986) e Hervé et al.(1986).

Ps. ferox tem sido encontrada portando ovos de Dermatobia hominis, cujas larvas causam o berne. Os hábitos diurnos e zoofilicos e a preferência desse 
mosquito pelas matas e capōes coincidem com os dessa mosca, o que deve facilitar o seu contato, ajudando na dispersão dessa mí́ase.

Outros Psorophora (Janthinosoma) têm sido incriminados como vetores de arbovírus. Tais mosquitos assumem hábitos muito semelhantes aos de Ps. ferox. São eles: Ps. lutzi (Theobald, 1901) e Ps. albipes (Theobald, 1907). Consulte Forattini (1965a) e Hervé et al. (1986), para obter dados adicionais sobre esses achados.

\section{GENERO HAEMAGOGUS WILLISTON, $18 \%$} tropicais.

É um gênero restrito ao Novo Mundo, e quase todas as espécies são Neo-

As espécies deste gênero estão entre os mais bonitos Culicinae. Seu corpo é recoberto de escamas de cores variadas e de reflexo metálico (azulado, esverdeado, violáceo, prateado). Parecem ser os culicíneos mais próximos, filogeneticamente, dos Sabethini, tribo que inclui os mosquitos de coloridos e brilhos mais intensos.

Enquanto as escamas abundam e recobrem o escudo e a pleura, as cerdas são geralmente ausentes ou pouco desenvolvidas, como por exemplo as dorsocentrais e acrosticais.

Seus antepronotos são desenvolvidos, maiores que o meron, sendo aproximados entre si ao exame dorsal. As espécies de Haemagogus até agora assinaladas no Brasil (8 espécies) apresentam garras tarsais femininas com dente sub-basal e o mesoposnoto nu.

São mosquitos essencialmente diurnos, silvestres e acrodendrófilos. Seus ovos, muito resistentes à dessecação, são colocados, isoladamente, em substratos úmidos de recipientes naturais. A eclosão se dá na época mais chuvosa do ano, quando os ovos de cada espécie parecem ter respostas diferentes aos estimulos externos para eclosão (número de contatos com a água), de maneira que as primeiras chuvas favorecem o aparecimento das larvas de alguns Haemagogus, enquanto outras de suas espécies nascerão quando a estação chuvosa já estiver plenamente estabelecida. Nota-se daf a forte influência das chuvas no ciclo anual desses Aedini, ou seja, a densidade populacional das espécies tem seu auge na estação chuvosa, umas no início e outras mais tarde.

Os criadouros preferidos dos Haemagogus são, decididamente, os buracos ou ocos de árvores. Podem ser encontrados criando-se, com muito menor freqüência, em cascas de frutas e internódio de bambu. Sua presença está vinculada à existência desses criadouros, o que torna os Haemagogus restritos às florestas e, no máximo, à sua vizinhança.

Existem dois subgêneros: Conopostegus Dyar, 1925 e Haemagogus Williston, 1896. Suas espécies podem ser idertificadas conforme abaixo (segundo Zavortink, 1972 e Arnell, 1973). 


\section{Chave para a identificação das fêmeas de Haemagogus que ocorrem no Brasil.}

1. Escudo coberto por escamas escuras com linha ou mancha acrostical, antealar e pré-escutelar de escamas prateadas; pleura com faixas verticais de escamas prateadas (Fig.22.1)

(subgênero Conopostegus)

Escudo coberto por escamas de brilho metálico verde, azul, cobre ou bronze, podendo ter escamas prateadas apenas na área antealar; pleura sem faixa de escamas prateadas

2. Mancha de escamas mesepimerais com uma expansão caudal no ápice superior; escamas eretas da cabeça inteiramente escura (marrom a enegrecido); 2 ou 3 cerdas pró-episternais fortes e longas. leucophoebus

Mancha de escamas mesepimerais simples ou com pequena extensão caudal no ápice superior; escamas eretas da cabeça algumas vezes inteiramente marrom pálido ou parcialmente brancas; 1 ou 2 cerdas pró-episternais fortes e longas leucocelaenus

3. Pronoto posterior aparentemente sem escamas (unhas tarsais masculinas medianas pequenas) tropicalis

Pronoto posterior densamente revestido de escamas (unhas tarsais masculinas medianas com uma grande e outra pequena)

4. Antepronotos completamente, ou quase completamente, coberto por escamas prateadas dorsalmente; [coxas totalmente prateadas, raramente com escamas escuras na coxa média; escamas do escudo de coloração cobre a bronze; tergitos abdominais com escamas de nuances azul, verde ou dourado]. spegazzinii

Antepronotos cobertos principalmente com escamas escuras, de nuances de azul, verde ou cobre, podendo apresentar poucas escamas prateadas marginalmente. 
5. Célula furcada anterior * $\left(R_{2}\right)$ tão ou mais longa que o pecíolo correspondente $\left(R_{2+3}\right)$ (geralmente $R_{2+3}=$ 0.55 de $R_{2}$ ); [escamas do escudo, occipício e antepronotos intensamente azuis; coxas com manchas conspícuas de escamas escuras; tergitos abdominais com escamas escuras, púrpura, com apenas manchas basolaterais claras]

baresi

Célula furcada anterior $\left(R_{2}\right)$ sensivelmente mais curta que o peciolo correspondente $\left(R_{2+3}\right)\left(R_{2+3}>\right.$ $0.7 \mathrm{de} \mathbf{R}_{2}$ )

6. Fêmur posterior com escamas prateadas se estendendo até quase o ápice, anteriormente; escamas escuras do abdome, de modo geral, predominantemente púrpura mas com outras verde-azuladas na margem distal dos tergitos V-VIII; probóscide medindo 1.10 a 1.15 do fêmur anterior janthinomys e caprico:nii

Fêmur posterior com escamas prateadas não ultrapassando os $75 \%$ da porção basal, anteriormente; escamas escuras dos tergitos abdominais I-VII de cor púrpura; probóscide medindo 1.25 do fêmur anterior albomaculatus

Como as formas imaturas de Haemagogus são muitas vezes menos encontradas que os adultos fêmea (em decorrência de seus criadouros serem de difícil acesso), não apresentaremos aqui uma chave dicotômica para sua identificação. Chaves para identificar larvas e machos (genitália) deste gênero encontram-se em Zavortink (1972) e Arnell (1973).

\section{Subgênero Haemagogus Williston, 1896}

As características morfológicas mais notáveis desse subgênero podem ser retiradas da própria chave dicotômica acima, no que se refere aos adultos fêmea, isto é, são os Haemagogus de escudo colorido de tons de verde, azul, cobre, bronze ou cores semelhantes, mas com forte brilho metálico. Além disso, não apresentam a pleura torácica listrada por faixas prateadas, (como nos Conopostegus) e as fêmeas das espécies brasileiras apresentam as unhas tarsais anteriores e médias denteadas.

A Célula furcada anterior, ou $R_{2}$ corresponde à área limitada pelas veias $R_{2}$ e $R_{3}$ e a borda da asa. 
No que diz respeito aos hábitos, são muito semelhantes entre si, ou seja, o que foi dito para o gênero como um todo pode ser considerado para as espécies em geral.

\section{Haemagogus janthinomys Dyar, 1921}

Distribuição geográfica. Ocorre do norte da Argentina e sul do Brasil até Honduras e Nicarágua, pela costa atlântica, pois não existe no litoral pacífico sul-americano. Atinge todos os Estados brasileiros acima do Paraná, áreas a leste dos Andes, do Peru a Colômbia, toda a Venezuela, as três Guianas e Trinidad e Tobago.

É encontrado quase exclusivamente em florestas tropicais úmidas primárias e nas suas imediaçōes.

Biologia. Seus hábitos são aqueles citados para o gênero. Ressaltamos aqui a resistência à dessecação de que são dotados seus ovos, os quais parecem necessitar de seguidos contatos com a água para a eclosão. Seus criadouros são buracos em árvore situados em locais muito altos e quase inatingiveis. Existe nítida preferência por picar nos niveis elevados da floresta, descendo para picar o homem (principalmente nos pés) ou animais, junto ao solo, quando estes provocam distúrbios na mata. S6 suga sangue durante o dia, especialmente nas horas mais claras ( $12 \pm 3$ horas.).

É notório que, devido à sua característica de espécie silvestre, $\mathrm{H}_{8}$. janthinomys é raramente encontrado em habitações humanas ou no peridomicílio. Sua importância epidemiológica reside na transmissão de patógenos em ambientes florestais e não naqueles.

Relação com a transmissão de arbovírus. Hg. janthinomys é o principal transmissor da forma silvestre da febre amarela em nosso país. É muito susceptível ao vírus amarílico e sua distribuição geográfica (e abundância) coincide com a grande área de maior endemicidade desta arbovirose no Brasil. Foi, basicamente, a partir de observações sobre o papel desse mosquito na veiculação dessa arbovirose que se formou o conceito de febre amarela silvestre no Brasil, visto que até a década de 1930 só conhecíamos a forma urbana da doença (Shannon et al., 1938; Laemmert et al., 1946; Causey et al., 1950).

A febre amarela silvestre no Brasil atinge predominantemente indivíduos do sexo masculino, entre 16 e 35 anos de idade (ou seja, quem entra nas matas com finalidades extrativistas), manifestando-se sobre a forma esporádica ou de pequenos surtos, que ocorrem, anualmente, quase sempre na época das chuvas. Nas últimas décadas, o menor número de casos nas Américas ocorreu na década de 1960 (cerca de 1.000). De lá para cá, os números têm aumentado progressivamente, de maneira que cerca de 1.600 casos foram registrados na década de $80,11,5 \%$ dos quais ocorridos no Brasil (países vizinhos, como Peru e Bolívia, contribuíram com $54 \%$ e $30 \%$ dos casos, respectivamente).

Hg. janthinomys e outras espécies co-genéricas mantêm epizootias dessa arbovirose entre macacos susceptiveis (e possivelmente marsupiais), dentro das matas. Os macacos e sagüis brasileiros são muito susceptiveis à febre amarela, 
amplificando (produzem altas viremias nos 6 primeiros dias de infecção) e disseminando, passivamente, o vírus (ao se deslocarem dentro de e entre florestas). Essas epizootias se originam numa localidade (principalmente nas Regióes Amazônica e Centro-Oeste) e migram, sem parar, enquanto encontram macacos susceptíveis e mosquitos vetores em seu território. Daí surgem os casos e surtos humanos.

Este Haemagogus, uma vez infectado, torna-se infectante por toda sua vida (que pode ser de até 3 meses) e permite a transmissão do vírus para a sua prole. Acredita-se que seus ovos podem manter o vírus ativo e latente, para causar epizootias nas épocas mais favoráveis. Além disso, suas fêmeas podem voar longas distâncias (até $11 \mathrm{~km}$ ), inclusive entre florestas separadas por cerrados. Enfim, Hg. janthinomys é um vetor-reservatório da febre amarela em nosso país.

Hg. janthinomys e outras espécies co-genéricas comprometidas com a transmissão da febre amarela silvestre veiculam o vírus entre macacos, na copa das árvores, descendo para atacar o homem ocasionalmente. Isto parece ocorrer nas épocas de elevada densidade do Aedino (chuvas) e devido a alterações na floresta, provocadas principalmente por desmatamentos (para construção de estradas, extração de madeira ou formação de pastagens ou plantações). Por isso, o homem é uma vítima acidental de ambos: do Haemagogus e da febre amarela silvestre.

Hg. janthinomys foi várias vezes encontrado naturalmente infectado com o vírus da febre amarela, algumas vezes com taxas de infecção muito altas (Barcarena, no Pará $=16,7 \%$ ). Além disso, não são raros os achados desse mosquito com infecção por outros arbovírus no Brasil (Forattini, 1965a; Arnell, 1973; Hervé et al., 1986).

\section{Haemagogus albomaculatus Theobald, 1903}

Distribuição geográfica. Está restrito ao norte da América do Sul, entre a foz do rio Orinoco, na Venezuela, e a Guiana Francesa, atingindo apenas o Suriname, a Guiana e o norte do Estado do Pará, no Brasil.

Biologia. É muito semelhante a do $\mathrm{Hg}$. janthinomys. Observou-se, porém, que na área de Monte Alegre, no Pará, este mosquito pica o homem, junto ao solo, em elevados números e com bastante agressividade, não se restringindo a fazê-lo dentro das matas, mas atacando na borda da floresta e na vizinhança das habitaçōes aí situadas. Foi ali capturado inclusive dentro das casas.

Relação com a transmissão de arbovírus. É considerado um vetor local da febre amarela, pois foi encontrado naturalmente infectado com o vírus em Monte Alegre (PA), isoladamente ou em "pools" contendo também $\mathrm{Hg}$. janthinomys. Lá, foram detectados casos de febre amarela em mulheres e até em crianças muito jovens (um caso fatal, com 2 anos de idade), o que chama a atenção para a capacidade de $\mathrm{Hg}$. albomaculatus transmitir a febre amarela fora do ambiente silvestre, no qual $\mathrm{Hg}$. janthinomys deve ser o responsável por manter o ciclo (Hervé et al., 1985; Hervé et al., 1986). 
Duas outras espécies do subgênero Haemagogus têm importância restrita como vetores de febre amarela e devem ser, no máximo, transmissores ocasionais ou locais da arbovirose. Săo elas: $\mathrm{Hg}$. capricornii e Hg. spegazzinii .

\section{Haemagogus capricornii Lutz, 1904}

É um mosquito genuinamente brasileiro. Ocorre somente no Sudeste do Brasil, do sul da Bahia ao norte do Rio Grande do Sul, incluindo os Estados de Minas Gerais, Rio de Janeiro, Espírito Santo, São Paulo, Paraná e Santa Catarina. É encontrado, basicamente, nas matas, nas áreas menos úmidas e de clima mais ameno do Sudeste brasileiro.

Não se sabe muito sobre a sua biologia, mas parece ter hábitos semelhantes às outras espécies co-genéricas. Foi por muito tempo confundido com o $\mathrm{Hg}$. janthinomys e muitos dados que se tinham sobre a sua biologia não podem ser considerados pertinentes. $\mathrm{Hg}$. capricornii cria-se quase exclusivamente em buracos de árvore, é diurno, mais freqüente nos meses chuvosos, acrodendrófilo e eclético quanto ao hospedeiro. Ataca o homem junto ao solo em condições semelhantes às citadas para $\mathrm{Hg}$. janthinomys (Forattini, 1965a; Forattini \& Gomes, 1988).

\section{Haemagogus spegazzinii Brethes, 1912}

Ocorre do Nordeste ao Sudeste do Brasil (de Pernambuco ao Rio de Janeiro), no Paraguai e do norte da Argentina ao leste da Bolívia, já tendo sido assinalado no Equador. Tem hábitos semelhantes aos da espécie supracitada (diurno, acrodendrofilo, silvestre). Suas larvas vivem nos buracos de árvore e internódios de bambu.

Em relação à transmissão da febre amarela, sabe-se que $\mathrm{Hg}$. capricornii parece ser eficiente transmissor do vírus em condições naturais e experimentais, enquanto $H_{8}$. spegazzinii não parece ser um vetor muito eficaz (Shannon et al., 1938; Arnell, 1973). Ambas as espécies foram encontradas naturalmente infectadas com o vírus amarílico no Sudeste brasileiro (Bahia e Rio de Janeiro, respectivamente), mas como sua distribuição nesta região coincide com a do $\mathrm{Hg}$. janthinomys, acredita-se que essas espécies tenham papel secundário na transmissão. $O$ desencadeamento das enzootias e a sua manutenção devem ser efetuados, provavelmente, por $\mathrm{Hg}$. janthinomys (Arnell, 1973).

\section{Subgênero Conopostegus Dyar, 1925}

São os Haemagogus escuros (tegumento marrom enegrecido, escuramente escameado), que possuem a pleura torácica listrada, verticalmente, por faixas de escamas prateadas e o escudo com ornamentação formada por faixas ou manchas longitudinais de escamas também prateadas.

Têm hábitos semelhantes aos do subgênero Haemagogus. Suas formas imaturas são encontradas em ocos de árvore, internódios de bambu ou mesmo em recipientes artificiais abandonados nas matas (mais raro). 
Há 4 espécies neste subgênero, duas das quais ocorrem no Brasil. Uma delas é espalhada em todo o nosso território - Hg. leucocelaenus, enquanto a outra Hg. leucophoebus (Galindo et al., 1953) - é restrita a duas localidades do Estado do Acre e não tem importância epidemiológica.

\section{Haemagogus leucocelaenus Dyar \& Shannon, 1924}

Distribuição geográfica. Parece se estender de Trinidad ao sul do Brasil (São Paulo) e ao norte da Argentina. Em nosso país tem sido assinalado, principalmente, nos Estados das regiōes Sul, Sudeste e Centro-Oeste (Zavortink, 1972).

Biologia. É, como os demais Haemagogus, essencialmente diurno e acrodendrófilo. Cria-se em buracos de árvore, mas suas larvas já foram achadas em internódios de bambu. As fêmeas atacam o homem e animais com muita agressividade, mesmo no solo, e têm boa capacidade de vôo (até quase $6 \mathrm{~km}$ ), inclusive em áreas parcialmente desmatadas, entre capões de mata.

Relação com a transmissão de arbovirus. Hg. leucocelaenus tem sido encontrado naturalmente infectado com alguns arbovirus, incluindo o da febre amarela, no Brasil. Foi por isso incriminado como vetor primário desta doença no Sudeste do país. Compõe junto com $\mathrm{Hg}$. janthinomys e $\mathrm{Hg}$. albomaculatus o grupo de Aedinos mais importantes na veiculação do vírus amarílico (Shannon et al., 1938; Kumm \& Cerqueira, 1951, Zavortink, 1972; Pinheiro et al., 1981; Hervé et al., 1986; Forattini \& Gomes, 1988).

\section{Tribo Culicini}

Inclui dois gêneros que ocorrem no Brasil: Culex e Deinocerites, aquele cosmopolita e este de distribuição restrita ao continente americano.

As espécies dessa tribo são muito variadas, tanto no que diz respeito à biologia quanto às características morfológicas.

São noturnos e crepusculares. Atacam o homem e uma enorme variedade de animais, mas não costumam ser tão agressivos como os Aedini. Os seus ovos não são resistentes à dessecação e são depositados em conjuntos em forma de "jangadas", mas há exceções a esta regra.

Criam-se em coleções líquidas no solo ou em recipientes, naturais ou artificiais, na maioria das vezes em caráter permanente.

\section{GENERO CULEX LINNAEUS, 1758}

São mosquitos que variam de pequeno a grande porte e têm coloração geral marrom ou enegrecida. Os adultos são desprovidos das cerdas pré e pós-espiraculares, mas apresentam pêlos no remígio. As antenas têm segmentos flagelares cilíndricos, o primeiro dos quais semelhante, em tamanho, ao segundo.

Pode-se dizer que, considerando o enorme número de espécies reunidas neste gênero, poucas de suas fêmeas detêm características muito marcantes e 
pouco variáveis. Isto torna bastante difícil a identificação das espécies coletadas na fase adulto-fêmea, com base na morfologia externa. Houve várias tentativas de compor chaves dicotômicas para as fêmeas, mas nenhuma das chaves obtidas parece ser suficientemente segura.

Contudo, a genitália masculina dos Culex apresenta características marcantes e o seu estudo é um dos melhores métodos para a identificação específica. Outra forma de identificá-los é através da quetotaxia das larvas.

Não apresentaremos, por essas razões, chave dicotômica para a identificação das fêmeas deste gênero, em nível específico. Daremos, para as espécies de interesse médico, os caracteres básicos para sua identificação neste sexo.

Chaves dicotômicas para a identificação da genitália masculina e das larvas de Culex podem ser encontradas em Rozemboom \& Komp (1950), Lane (1953), Froote (1954), Forattini (1965a), Bram (1967), Valencia (1973), Berlin \& Belkin (1980), Sirivanakarn (1982) e Darsie \& Mitchell (1985).

Os Culex têm hábitos noturnos e crepusculares, mas algumas espécies podem sugar sangue durante o dia, quando o hospedeiro se encontra próximo aos seus abrigos e criadouros. São muito atraídos pela luz artificial e muitas vezes compõem a maior parte das capturas feitas com armadilhas luminosas.

Depositam seus ovos em conjuntos, com aspecto de "jangada", que flutuam na superfície da coleção líquida, com exceção de poucas espécies do subgênero Melanoconion. Seus criadouros variam muito e alguns detalhes sobre eles serão dados à frente, no comentário sobre as espécies ou subgêneros.

Há espécies estenogâmicas e eurigâmicas no gênero. Algumas são essencialmente silvestres, enquanto outras são semisilvestres ou suburbanas e poucas delas são definitivamente urbanas e domésticas.

Apenas 8 subgêneros de Culex ocorrem no Brasil, cujos adultos podem ser separados de acordo com a chave a seguir, adaptada de Berlin \& Belkin (1980).

\section{Chave para a identificação dos subgêneros de Culex que ocorrem no Brasil, na fase adulta.}

1. Cerdas acrosticais desenvolvidas na área central do escudo (Fig. 1.b, c)

Cerdas acrosticais não desenvolvidas (Fig. 29.a), exceto na extremidade anterior do escudo e/ou próximo ao espaço pré-escutelar (podem ser conspícuas nos Melanoconion da seção Spisseps)

2. Cerdas mesepimerais inferiores geralmente em número de 6 ou mais; todos os fêmures salpicados; veia Costa com áreas alternadas de escamas marrom e amarelas (Fig. 29.b); mosquitos de porte avantajado 
Cerdas mesepimerais inferiores (Mei) ausentes ou èm número de 1 ou 2 (Figs. 29.e; 30.b), raramente 3 ou mais; fêmures não conspicuamente salpicados; veia Costa sem áreas claras e escuras alternadas; mosquitos de porte médio ou pequeno

3. Pleura com distintas manchas de escamas no mesocatepisterno (Fig. 30.b)

Pleura com, no máximo, algumas escamas junto às cerdas do mesocatepisterno 5

4. Escudo com nítida e contínua faixa de escamas brancas ou cremes lateralmente, da região anterior até $\mathbf{a}$ área supra-alar, além de outras ornamentações Phenacomyia

Escudo recoberto por escamas de uma só cor ou, quando ornamentado, as escamas claras não formam uma faixa como acima Culex

5. Tarsos com mancha clara basal; ou tarsos completamente escuros, mas com pleura clara apresentando manchas escurecidas no tegumento (Fig. 1.b) Microculex (parte)

Tarsos completamente escuros; pleura com tegumento uniformemente pálido ou amarelado Anoedioporpa (parte)

6. Tergitos abdominais com áreas claras basolaterais de escamas claras com reflexos metálicos Carrollia

Tergitos abdominais completamente escuros ou com áreas de escamas claras, às vezes brilhantes, mas sem reflexos metálicos

7. Vértice geralmente com todas as escamas deitadas largas (Fig. 29.f) ou com pelo menos uma linha de escamas largas deitadas ao longo da margem orbital Melanoconion

Vértice com todas as escamas estreitas, mesmo ao longo da linha orbital (Figs. 1.a; 30.a) 

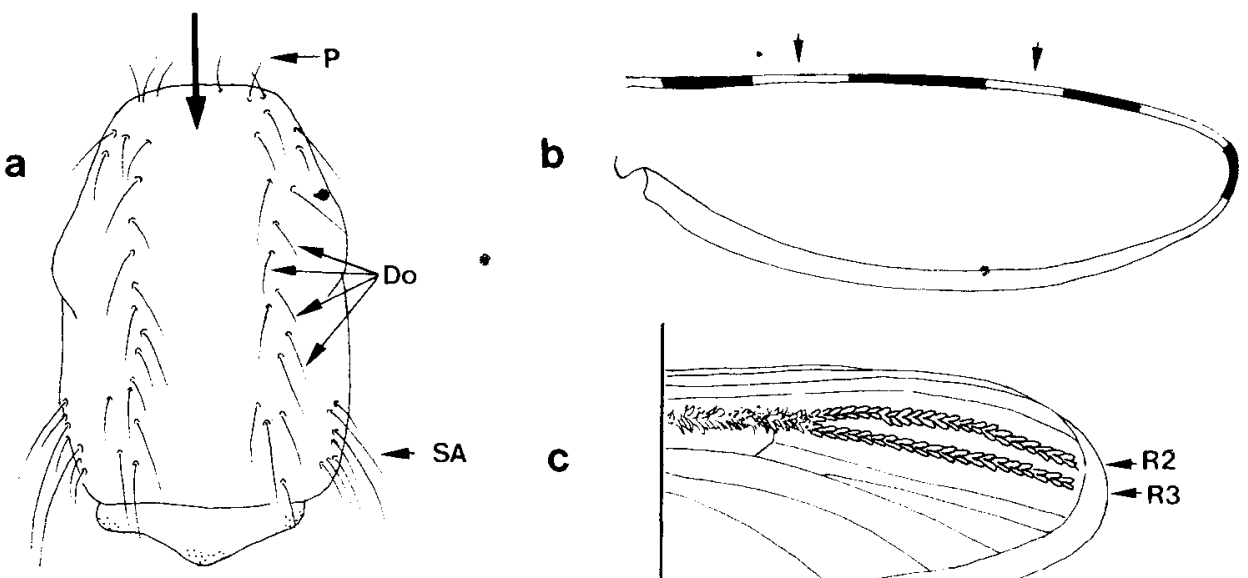

b

C
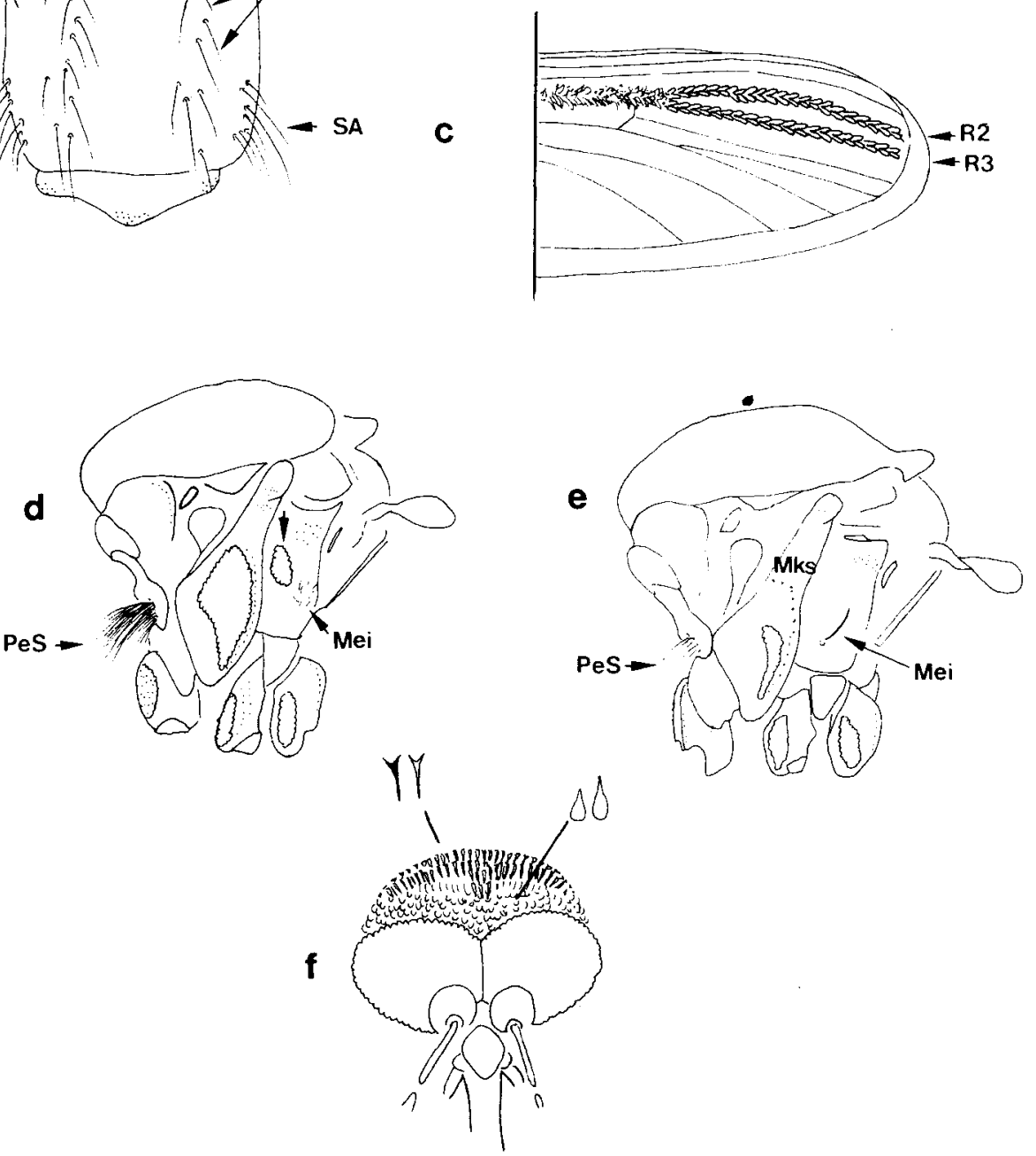

FiG. 29: Aspectos da morfo'ogia externa de Culex adulto. Ilustrações referidas na chave dicotômica. a: mesonoto (escudo + escutelo), vista dorsal [cerdas dorsocentrais (Do), promontoriais (P) e supraalares (SA)]; b: asa, veia Costa; $c$ asa, destaque para o ápice veias $\left(\mathbf{R}_{2}\right.$ e $\left.\mathbf{R}_{3}\right)$; d, e: tórax, vista lateral [cerdas proepisternais $(\mathrm{PeS})$ e mesepimerais inferiores (Mei); mesocatepisterno superior (MKs)]; f: cabeça, vista dorso-frontal com destaque para as escamas do vértice e do occipício. 
8. Cerdas pró-episternais superiores $(\mathrm{PeS})$ muito fortemente desenvolvidas e numerosas, pelo menos 20 (20-25); área mediana do mesanepímero com uma mancha de escamas e pêlos curtos (Fig. 29.d) Tinolestes

Cerdas pró-episternais superiores $(\mathrm{PeS})$ pouco desenvolvidas, menos de 10 (geralmente cerca de 5); área mediana do mesanepímero sem mancha de escamas ou pêlos curtos (Fig. 29.e)

9. Veias $R_{2}$ e $R_{3}$ somente com escamas largas

(Fig. 29.c); mesocatepisterno com mancha estreita de escamas transluzentes Aedinus

Veias $R_{2}$ e $R_{3}$ com escamas estreitas (Fig. 1.d) 10

10. Mesocatepisterno superior com mancha distinta de escamas Microculex (parte) Mesocatepisterno superior sem mancha de escamas Anoedioporpa (parte)

Para identificação dos subgêneros nas formas imaturas e genitália masculina pode-se consultar as chaves apresentadas por Berlin \& Belkin (1980).

Os mosquitos dos subgêneros Culex e Melanoconion são os de maior importância epidemiológica no gênero Culex. Transmitem arboviroses e filariose, dentre outros patógenos.

\section{Subgênero Culex Linnaeus, 1758}

Os Culex (Culex) têm porte médio, coloração geral marrom escuro ou claro, sem brilho metálico e asas com escamas escuras em sua totalidade (há poucas espécies com raras escamas claras na base das veias anteriores). $O$ occipício apresenta as escamas decumbentes alongadas, estreitas e curvas e as escamas eretas com ápice forquilhado.

Os machos têm sempre antenas fortemente plumosas e palpos maiores que a probóscide. Na genitália destaca-se o ápice do paraprocto, que é dotado de uma densa "moita" de espículos pontiagudos.

As larvas têm cerda 2-C fracamente desenvolvida ou mesmo ausente; cerda 4-X com 5 ou mais pares de pêlos; sela do lobo anal com bordo caudolateral sem espinhos ou com espículos rudimentares; cerda 3-P quase do mesmo porte da 1-P.

São essencialmente noturnos e a maioria das espécies brasileiras parece ter certa atração pelas aves, atacando também mamíferos, inclusive o homem. Usam criadouros muito diversificados. 


\section{Culex quinquefasciatus Say, 1823}

Diagnose. Adultos: Tarsos escuros, sem marcação clara; escudo com tegumento marrom (claro ou escuro), densamente recoberto de escamas amarelodouradas, estreitas, alongadas e curvas (semelhantes a pestanas) (Fig. 30.b); occipício com a região antero-central com escamas eretas forquilhadas esbranquiçadas, as laterais e posteriores escuras (Fig. 30.a).

Larvas: Têm superfície corporal glabra; sifão longo ( 4 ou 5 vezes o valor da largura basal), cerda $1-S$ constituída de 4 cerdas desenvolvidas (de comprimento igual ou maior que a largura do sifão), aciculadas (pelo menos as basais), algumas implantadas fora de alinhamento (Fig. 30.d); cerda 4-C fina, simples ou dupla, não aciculada (Fig. 30.c).

Distribuição geografica. É considerado cosmopolita, ou melhor, trópicocosmopolita. Ocorre, basicamente, nas porções meridionais da Ásia, na África, nas Américas (do sul dos E.U.A. ao norte da Argentina) e na Oceania. Foi originalmente descrito de espécimens de New Orleans, E.U.A.

É conhecido como o mosquito doméstico tropical (do sul), por representar uma praga para os moradores das áreas menos frias dos continentes supracitados.

Ocorre em todo o Brasil, mas com distribuição e abundância fortemente influenciadas pela presença do homem (Forattini et al., 1993). É encontrado em maior quantidade nos aglomerados humanos, dentro das cidades e vilas rurais, tornando-se raro à medida em que as habitações vão se afastando umas das outras, até inexistir nos locais onde o homem ainda não chegou ou que há muito abandonou.

É o mosquito mais conhecido pelos habitantes das vilas rurais e das cidades, pois os ataca exatanıente no horário destinado ao repouso, após a jornada de trabalho ou estudo.

Foi por muito tempo conhecido como $C x$.fatigans ou Cx.pipiens fatigans (ver Belkin, 1977 e Sirivanakarn \& White, 1978).

Biologia. Seus criadouros preferenciais são os depósitos artificiais, no solo ou em recipientes, com água rica em matéria orgânica em decomposição e detritos, de aspecto sujo e mal cheirosa. Estão sempre próximos às habitações, pois esse Culex é extremamente beneficiado pelas alterações antrópicas no ambiente peridomiciliar.

Os recipientes artificiais transitórios, geralmente sombreados, como vasilhames de diversos tamanhos (latas de conserva e bebida, copos, bebedouros de animais, latões) são muito procurados para desova e criação de $C x$. quinquefasciatus. Porém, também emprega muito as águas estagnadas e poluídas no solo, como valas de águas servidas principalmente em residências, fossas, ralos, poços, cisternas e impressões de pneus e de patas de animais.

É mais freqüente nos meses quentes e chuvosos, pois a água das chuvas que se acumula no solo e nos recipientes amplia seus criadouros. Entretanto, é coletado durante todo o ano, ininterruptamente. 

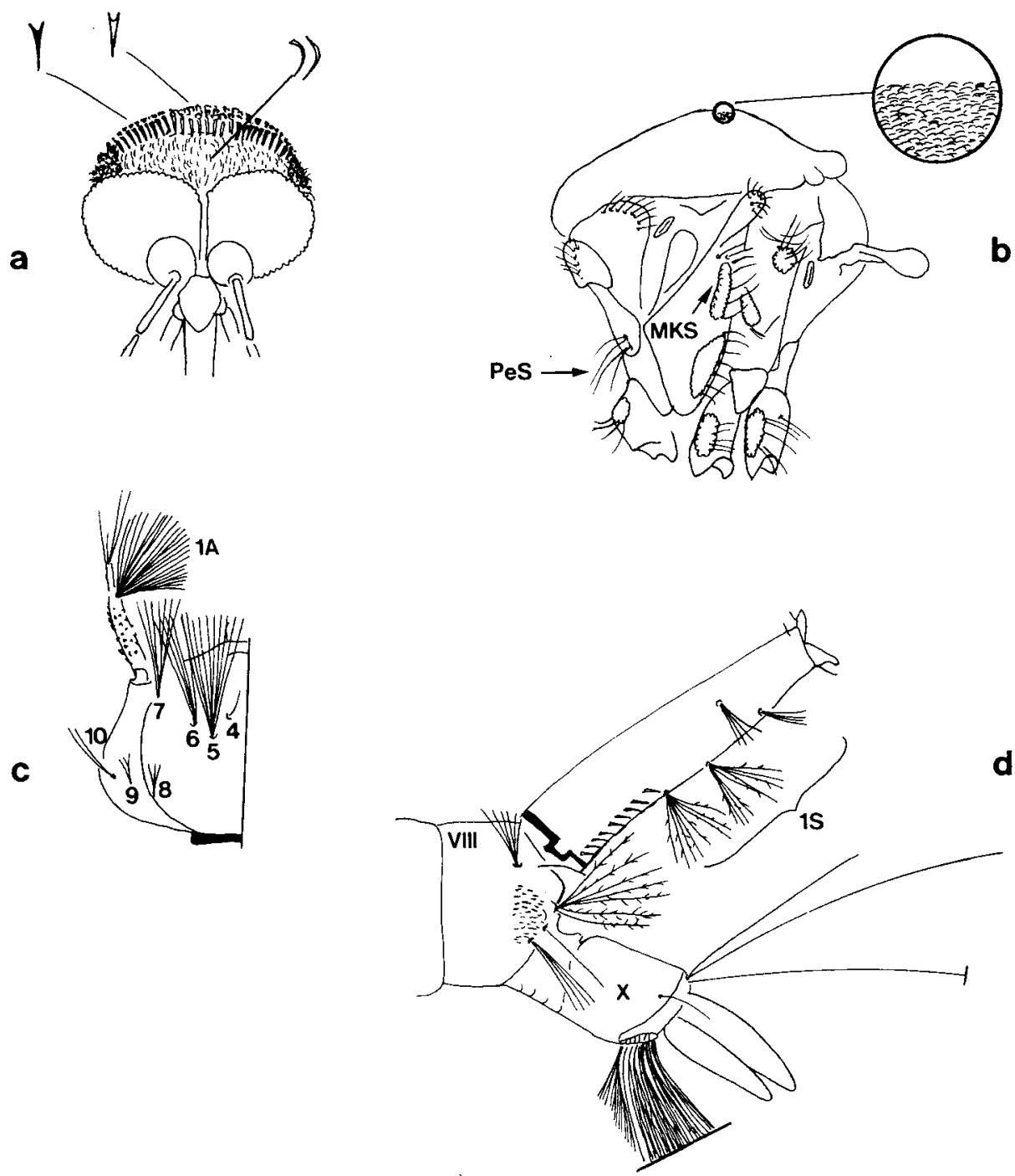

FIG. 30: Aspectos da morfologia externa de Culex quinquefasciatus. a: cabeça do adulto, vista dorso-frontal, com destaque para as escamas do vértice e do occipício; b: tórax do adulto, vista lateral, com destaque para as escamas do escudo [cerdas proepisternais (PeS); mesocatepisterno superior (MKs); c: cabeça da larva, vista dorsal; d: abdome da larva, vista lateral dos segmentos VIII e $\mathrm{X}$ e do sifão. 
Cx. quinquefasciatus é obrigatoriamente noturno. Embora fêmeas e machos invadam habitações humanas e ali se abriguem durante o dia e à noite, aquelas só se estimularão à hematofagia ao crepúsculo vespertino e à noite. Atacam o homem e animais, situados dentro das casas e no peridomicílio, durante toda a noite. Porém, preferem as horas mais avançadas da noite e os momentos que precedem $o$ amanhecer.

É considerado altamente antropofilico. Realmente procura o homem, dentro de sua habitação, para exercer o hematofagismo. Há neste mosquito, porém, uma certa ornitofilia, pois após o homem, são as aves domésticas as vítimas mais atacadas pelas suas fêmeas. Sabe-se que fêmeas alimentadas com sangue de ambos hospedeiros produzem mais ovos do que aquelas que se engorgitam com sangue de outras origens. Em condições experimentais, verificou-se considerável saurofilia. Mas mesmo sendo capaz de se alimentar em outros animais, em condições naturais, quando o homem está presente é ele o alvo preferencial da hematofagia do Cx. quinquefasciatus.

É o mosquito mais freqüente dentro das casas, no Brasil, sendo, em muitas cidades, praticamente o único a sugar o sangue do homem dentro das casas, à noite. Dotado de enorme endofilia, permanece dentro das habitações, abrigado embaixo e atrás dos móveis, em sótão ou porão, principalmente nos dormitórios, antes e após a alimentação sanguínea. $O$ freqüiente encontro de machos $e$ fêmeas em números semelhantes dentro das casas denota a endofilia deste mosquito.

Embora divida com Ae. aegypti o território na habitação humana e suas vizinhanças, $C x$. quinquefasciatus ocupa nichos diversos e atua em horário diferente daquele, apresentando nítidas diferenças biológicas. Suas larvas encontram-se em águas com muita matéria orgânica em decomposição, muitas vezes em fermentação, poluídas e turvas, ao passo que as do Ae. aegypti ocorrem nas águas transparentes, claras e limpas. As fêmeas de $C x$. quinquefasciatus sugam à noite e as de Ae. aegypti de dia. Os ovos de $C x$. quinquefasciatus são depositados diretamente sobre a água dos criadouros, em "jangadas", enquanto que os de Ae. aegypti (resistentes à dessecação) são depositados, individualmente, fora do líquido dos criadouros já formados ou não, em locais úmidos que o nível d'água alcançará, no futuro. Os ovos de $C x$. quinquefasciatus murcham fora d'água. Ambos os mosquitos são estenogâmicos.

Relação com a transmissão da filariose. $C x$. quinquefasciatus é o vetor primário e principal da filariose bancroftiana no Brasil. Sua predileção pelo sangue do homem (único hospedeiro da $W$. bancrofti) e a sua preferência por sugar durante a noite (período de aumento da microfilaremia periférica) facilitam muito o contato das microfilárias com este culicíneo, tornando-o mais eficaz que os outros mosquitos susceptíveis.

Vários estudos levados a efeito durante a década de 1950 demonstraram uma nítida relação entre a distribuição e abundância de $C x$. quinquefasciatus e os focos de $W$. bancrofti no Brasil. Nessas ocasiōes $C x$. quinquefasciatus foi várias vezes encontrado portando larvas infectantes desse parasito, inclusive com elevadas taxas de infecção. Transmitia a filariose em Manaus, Belém, Recife, Maceió, 
Salvador, Florianópolis e Porto Alegre, dentre outras localidades do país (Deane, 1951; Rachou, 1956).

A incidência dessa filariose no Brasil baixou muito nos útimos 30 anos. Hoje, embora exista em índices quase nulos em algumas daquelas localidades, vem-se tornando um sério problema em Recife, Jaboatão e Olinda, no Estado de Pernambuco, e em Maceió, Alagoas. Lá, $C x$. quinquefasciatus persiste na tarefa de transmitir as formas infectantes do parasito.

Relação com a transmissão de arboviroses. $C x$. quinquefasciatus tem sido incriminado como vetor de arbovírus dentro de vilas rurais e cidades. Foi encontrado naturalmente infectado com vírus causadores de encefalites, como dos tipos St. Louis, Oeste (nos E.U.A.) e Venezuelana (Panamá).

No Brasil, é também responsável pela veiculação do vírus Oropouche. É considerado vetor secundário dessa arbovirose em áreas do Estado do Pará, onde a doença tem causado várias epidemias, sendo que em seis das quais mais de 37.000 pessoas foram atingidas. No primeiro trimestre de 1991, cerca de 58.000 indivíduos foram acometidos pelo Oropouche, em Rondônia. O maruim ou mosquito-pólvora Culicoides paraensis (Diptera: Ceratopogonidae) é o transmissor primário do Oropouche, desencadeando epidemias rurais (principalmente próximo às plantações de cacau), que se alastram para as vilas e cidades. Nesses locais, mesmo na presença de $C$. paraensis, o vírus é também transmitido por Cx. quinquefasciastus.

Detalhes sobre a biologia de $C x$. quinquefasciatus e sua participação na transmissão da filariose e do Oropouche no Brasil, podem ser obtidos nas referências a seguir: Causey et al. (1945), Deane (1951), Rachou (1956), Rachou et al. (1957), Rachou et al. (1958), Forattini (1965 a), Scorza (1972), Pinheiro et al. (1981), Hervé et al. (1986), Forattini et al. (1987), Hoch et al. (1987), Dreyer \& Medeiros (1990), Dreyer et al. (1991), Medeiros et al. (1992).

Os demais Culex (Culex) não têm importância epidemiológica tão grande como o $C x$. quinquefasciatus. Embora algumas das espécies desse subgênero tenham sido incriminadas como transmissoras de patógenos, nenhuma delas, até hoje, representou um problema tão sério de saúde pública em nosso país como esse mosquito doméstico.

A seguir, daremos alguns dados da biologia de algumas espécies desse subgênero, por serem as mais comuns ou por serem vetoras de patógenos.

\section{Culex nigripalpus Theobald, 1901}

Tem patas escuras (tarsos sem marcação clara); escudo marrom, coberto de escamas escuras, bronzeadas, muito pequenas (curtas), que dão a esta porção aspecto de orvalhado; o occipício tem escamas escuras em sua totalidade; a pleura torácica é pálida, sem manchas escuras evidentes; o mesanepímero apresenta-se sem escamas na porção mediana.

Este mosquito ocupa grande parte da América Tropical (do sul dos E.U.A. ao Paraguai e sul do Brasil), exceto o seu extremo sul. É muito freqüente nas baixadas. Prefere criar-se em coleções líquidas no solo, principalmente as de 
caráter natural e permanente (charcos, alagados, bolsões de rios, canais, lagos), geralmente com águas profundas, frias, sombreadas, poluídas ou não. Pode ser achado também em criadouros artificiais.

E mais freqüente nos meses quentes e chuvosos, quando tem maior opção de criadouros, embora ocorra durante todo o ano. Pica essencialmente ao crepúsculo vespertino e à noite, de preferência as aves, mas ataca também mamíferos grandes e o homem. É exófilo, mais comum nos ambientes silvestres, semisilvestres ou no peridomicilio (principalmente nos abrigos de aves domésticas), e raramente invade as casas.

$C x$. nigripalpus tem sido detectado com infecção natural por alguns arbovírus, inclusive causadores de encefalites, mas não no Brasil (E.U.A., Trinidad e Jamaica). Sua ornitofilia, porém, permite-lhe veicular tais vírus entre pássaros silvestres, aves, mamíferos domésticos e o homem. Veja mais detalhes sobre a biologia de Cx. nigripalpus em Forattini (1965a), Nayar (1982), Lourenço-de-Oliveira et al. (1985) e Lourenço-de-Oliveira \& Castro (1989).

\section{Culex coronator Dyar \& Knab, 1906}

É considerado um complexo de 6 espécies cujas fêmeas e fases imaturas têm características morfológicas comuns, mas que são separáveis principalmente pelo estudo da genitália masculina. Delas, apenas duas têm sido assinaladas no Brasil: $C x$. coronator, a mais conhecida e amplamente distribuída nas Américas e $C x$. usquatus Dyar, 1925, provavelmente com distribuição geográfica menor, mas coincidente com a anterior, em nosso país.

$C x$. coronator e $C x$. usquatus têm patas com nítida anelação branca nos tarsos; mesomeron total ou parcialmente escuro; escudo com tegumento enegrecido, com ornamentação formada por escamas bronzeadas escuras e prateadas, todas estreitas e encurvadas. Sua larva tem espinhos salientes subapicais no sifão.

Seus criadouros preferidos parecem ser aqueles no solo: permanentes, ensolarados ou sombreados, de águas límpidas ou turvas (charcos, pântanos, nascentes represadas) ou mesmo os transitórios (valas de drenagem, poças, impressão de pneus e patas de animais). Apreciam menos os recipientes. A densidade de adultos de ambas espécies é positivamente influenciada pelas chuvas. São exófilas (vivem principalmente nas matas secundárias e capões), noturnas e zoofilicas, com tendência à ornitofilia. Picam o homem, ocasionalmente, fora das casas (Forattini, 1965a; Lourenço-de-Oliveira et al., 1986; Lourenço-de-Oliveira, 1989).

Cx. coronator (lato sensu) tem sido encontrado veiculando arboviroses causadoras de encefalites (tipo St. Louis, no Brasil e Trinidad e tipo Venezuelana, no México) ou de doenças febris (no Brasil) (Forattini, 1965a; Hervé et al., 1986; Castro et al., 1991).

\section{Culex saltanensis Dyar, 1928}

É bastante semelhante ao $C x$. coronator, mas difere desse por apresentar o mesomeron claro ou pouco pigmentado; o tegumento do escudo é marrom (rara- 
mente enegrecido), com ou sem ornamentação de escamas claras. Tem sido assinalado na Argentina, Brasil, Venezuela e Panamá. É mais freqüente nas baixadas, abrigando-se nos seus capões de mata, saindo para picar à noite nos descampados, embora possa sugar mesmo durante o dia nos locais mais protegidos.

Prefere as coleções de água transitórias, geralmente sem vegetação e ensolaradas, de águas turvas, muito poluídas e mal cheirosas (poças, valas, impressões de rodas e cascos). Não se cria em águas profundas, muito sombreadas, frias e limpas. Ocorre durante todo o ano, mas abunda na primavera e quando do início das chuvas torrenciais. É fortemente ornitófilo mas pica o homem e outros mamíferos, em menor proporção.

É o único vetor primário conhecido da malária que acomete as galinhas no Brasil e Américas em geral, causada pelo Plasmodium juxtanucleare. Este parasito parece ter grande importância econômica, reduzindo a postura e retardando o crescimento das aves criadas com fim comercial. Além de ser muito susceptível e eficaz transmissor desse parasito de importância veterinária é bom vetor experimental para o Plasmodium cathemerium, outro parasito aviário (Lourenço-de-Oliveira \& Castro, 1991; Gabaldon et al., 1988).

\section{Culex declarator Dyar \& Knab, 1906}

Tem tarsos com marcação clara, esbranquiçada ou amarelada, nítida ou não; a área pós-espiracular é sem escamas; o promontório anterior tem escamas claras e brilhantes; o tegumento da pleura é claro, com mancha escura no mesanepímero, que pode invadir o mesocatepisterno; o mesomeron é claro; o escudo é marrom claro, recoberto por escamas douradas.

Ocorre do sul dos E.U.A. até o Uruguai e Paraguai, incluindo as Antilhas Menores e Trinidad. É muito espalhado no Brasil, principalmente nas áreas de baixadas ou regiões pouco montanhosas. Cria-se em condições semelhantes ds citadas para $\mathrm{Cx}$. nigripalpus. Suas fêmeas atacam durante todo o ano; sua densidade não é muito influenciada pelas chuvas. São noturnas, exofilas, zoofilicas (com tendência à ornitofilia), picando o homem ocasionalmente. $C x$. declarator parece transmitir arbovírus no Brasil (Amazônia) e em Trinidad (Forattini, 1965a; Lourenço-de-Oliveira et al., 1985; Hervé et al., 1986).

\section{Subgênero Melanoconion Theobald, 1903}

Este subgênero tem recebido maior atenção dos investigadores recentes, pois algumas de suas espécies têm demonstrado participação na veiculação de patógenos, especialmente de arbovírus, no Brasil e em outros países. $O$ estudo taxonômico de Melanoconion brasileiros desenvolvido nas últimas três décadas ainda não permitiu a composição de chaves dicotômicas para a identificação segura de todas as espécies. O estudo da genitália masculina ainda é a forma mais utilizada para a identificação de suas espécies.

Hoje se conhecem três seções no subgênero Melanoconion: Ocellatus, Melanoconion e Spisseps. As espécies apresentando mancha escura e arredondada da área antealar do escudo foram agrupadas na seção Ocellatus. Esses mosqui- 
tos são biológica e filogeneticamente intermediários entre aqueles dos subgêneros Melanoconion e Microculex, criando-se em recipientes naturais, essencialmente em bromélias, como as espécies desse último grupo. Os mosquitos desprovidos de mancha escura na área antealar acham-se nas outras seções. Assim, aqueles com todas as escamas decumbentes do vértice largas, tal como espátulas, ou com muito raras escamas estreitas decumbentes, localizadas na porção central e cujos tegumentos pleural e escutal são igualmente escuros ou com o mesocatepisterno e o mesepímero atravessados por faixas escuras, são os da seção Melanoconion. Os espécimes com vértice ricamente coberto por escamas estreitas, falsiformes, ou mesmo aqueles em que essas escamas acham-se mais restritas à porção central, mas cujo tegumento pleural é bem pálido, contrastando com o tegumento escuro do escudo, estão na seção Spisseps.

As espécies da seção Ocellatus foram revisadas por Duret (1969), e as das seçōes Melanoconion e Spisseps foram estudadas por Sirivanakarn (1982), Forattini \& Sallum (1987; 1989; 1992; 1993 a, b) e Sallum (1994).

Os Melanoconion criam-se em locais muito diversificados (preferencialmente sem salinidade), desde recipientes naturais (como bromélias) a grandes coleções líquidas no solo (como bolsōes de rios, charcos, alagados e lagos).

São essencialmente crepusculares e noturnos, zoofílicos e exófilos, sendo que alguns apresentam capacidade de adaptação ao ambiente modificado pelo homem, mas não gostam dos descampados.

Alguns arbovírus causadores de doenças febris e de encefalites têm sido isolados de espécimes de $C x$. (Melanoconion). Além disso, em algumas ocasiōes houve certas evidências de que espécies deste subgênero estavam envolvidas na transmissão desses patógenos, inclusive no Brasil.

Dados adicionais sobre a biologia e a importância médica dos Melanoconion no Brasil podem ser obtidos na literatura (Forattini, 1965a; Natal, 1981; Hervé et al., 1986; Forattini et al., 1986; Forattini et al., 1987; Forattini et al., 1991).

Os demais subgêneros de Culex têm pouca ou nenhuma importância médica conhecida. As espécies de Aedinus Lutz, 1904 parecem optar por criar-se em coleções líquidas no solo, permanentes, de águas limpas, frias e sombreadas (charcos, alagados, valas de drenagem). Têm a densidade pouco influenciada pelas chuvas, mas podem ser mais freqüentes no final do perícdo de maior precipitação. São exófilos (algumas vezes são atraídos pela luz para dentro das casas), noturnos e zoofílicos (atacam aves e mamíferos, inclusive o homem) (Lourenço-de-Oliveira et al., 1985; 1986; Lourenço-de-Oliveira \& Heyden, 1986). Alguns vírus foram isolados de $C x$. amazonensis, mas não no Brasil.

Os Microculex Theobald, 1907 criam-se em bromélias e em outros recipientes naturais e parecem preferir picar animais de sangue frio (anfíbios) (Lourenço-de-Oliveira \& Heyden, 1986). Não têm importância médica.

Os Carrollia Lutz, 1901 e Anoedioporpa Dyar, 1923 criam-se em recipientes naturais, preferencialmente em buracos de árvore e são muito raramente vistos sugando o homem, razão pela qual detêm pouca importância epidemiológica. Dados sobre a distribuição, biologia e importância desses quatro últimos subgêneros e sobre Tinolestes Coquillett, 1906 podem ser obtidos na seguinte literatu- 
ra: Lane \& Whitman (1951), Lane (1953), Valencia (1973) e Berlin \& Belkin (1980). Phenacomyia Harbach \& Peyton, 1992 compreende poucas espécies biologicamente semelhantes aos do subgênero Culex.

Os Lutzia Theobald, 1903 não são antropofílicos e pouco se sabe sobre suas preferências. $O$ que devemos destacar é que suas larvas são predadoras e vivem em coleções líquidas no solo (ver Lane, 1953, para identificação das duas espécies brasileiras).

\section{GENERO DEINOCERITES THEOBALD, 1901}

São semelhantes aos Culex com respeito à morfologia externa dos adultos, diferindo principalmente por apresentar o primeiro segmento flagelar da antena muito longo, bem maior que o segundo (nas fêmeas é várias vezes maior).

As larvas vivem nos buracos de caranguejo, com água doce ou salobra, onde também se abriga a maior parte dos adultos. Raramente utilizam outros locais para se criar, como buracos de árvore e escavaçōes em pedra. Ao contrário dos Culex, os Deinocerites depositam os ovos separadamente, acima do nível da água.

Os adultos são noturnos e crepusculares, voam pouco e têm um dos maiores espectros de hospedeiros, sugando do homem (muito raro) até batráquios e répteis (Tempelis \& Galindo, 1970).

A cópula dá-se em pequenas nuvens ou individualmente. Os machos de Deinocerites são vistos sobrevoando ou pousados sobre o exato local, no criadouro, onde se acha a pupa que originará a fêmea, para fecundá-la imediatamente após a emergência.

Sua importância epidemiológica é restrita ou quase nula. Algumas vezes esses mosquitos foram encontrados com arbovírus, mas não se sabe qual a importância desses achados. Informações adicionais sobre sistemática e biologia de Deinocerites podem ser obtidas em Adames (1971).

\section{Tribo Mansoniini}

Os Mansoniini têm em comum uma interessante característica biológica nos estágios imaturos. As larvas de primeiro estágio movimentam-se livremente na água durante algum tempo após a eclosão do ovo, obtendo oxigênio na superfície líquida, como fazem os demais culicíneos. Aos poucos, vão localizando raízes de plantas flutuantes ou não (Eichornia, Pistia, Salvinia, Typha e gramíneas), ou outros tecidos vegetais submersos, onde se fixam perfurando esses tecidos a custa de dentes fortes existentes no ápice do sifão respiratório. A partir de então, durante todos os demais estágios larvais e pupal (sua trombeta respiratória tem aspecto de corno, com ápice bem quitinizado, adaptado para perfurar), retiram todo o oxigênio que necessitam dos parênquimas aeríferos.

As formas imaturas podem mudar de um local para outro numa mesma planta ou desta para outro vegetal. No momento da emergência do adulto a pupa se desprende da planta e migra para a superfície. 
As larvas se alimentam de matéria orgânica em suspensão na água do criadouro, pois não descem ao fundo ou sobem à superfície para procurar, ativamente, o seu alimento.

Os ovos dos Mansoniini são depositados em conjuntos flutuantes ou submersos.

São mosquitos muito zoofilicos, oportunistas, grandes e vorazes. Atacam em maiores números no crepúsculo vespertino e à noite, mas podem atacar o homem ou animais a qualquer hora do dia, quando estes estão próximos aos abrigos e criadouros desses insetos. São verdadeiras pragas, dificultando a vida humana e a pecuária em certas regiōes. Um exemplo desse problema vem ocorrendo na área de influência da usina hidrelétrica de Tucuruí, no rio Tocantins (Tucuruí, Itupiranga e Jacundá), no Pará, onde centenas de famílias abandonaram suas casas e roças e cerca de 1.000 , que ali permaneceram, sofrem o ataque quase ininterrupto dos Mansoniini que se criam no enorme lago da hidrelétrica.

Sob o ponto de vista morfológico, os adultos têm coloração escura, escamas da asa alargadas, abdome com ápice truncado e patas francamente marcadas de branco (Fig. 22.e, g). As larvas têm antenas bem longas e sifão bem curto (geralmente bem menor que o lobo anal), escuro e cônico, com dentes cortantes na face dorsal (Fig. 24.c).

Há dois gêneros em Mansoniini: Mansonia e Coquillettidia.

\section{GENERO MANSONLA BLANCHARD, 1901}

São mosquitos muito robustos, de porte médio ou grande, com escudo de aspecto felpudo (principalmente na área supralar), asa e fêmures bem salpicados, sendo as escamas das asas bem largas.

Os ovos de Mansonia são depositados em conjuntos geralmente de contorno circular, sob folha de plantas flutuantes, como mururês (Salvinia) e erva de Santa Luzia (Pistia), dentre outras. Não ficam, portanto, flutuando, mas submersos na água. Durante a desova, as fêmeas introduzem o ápice do abdome na água, prendendo os ovos na face inferior da folha escolhida.

As espécies de Mansonia não são vetoras de doenças endêmicas no Brasil. Algumas já foram encontradas naturalmente infectadas com arbovírus, inclusive causadores de encefalites, e devem ser transmissoras potenciais desses agentes. Por outro lado, podem tornar certas localidades impróprias à habitação ou à pecuária, por causa de seu hematofagismo agressivo.

Em vista de sua restrita implicância na transmissão de patógenos, não apresentamos chave dicotômica para a identificação de suas espécies, a qual pode ser encontrada em Barreto \& Coutinho (1944), Lane (1953) e Forattini (1965b).

Seguramente 9 espécies de Mansonia ocorrem no Brasil, das quais Ma. titillans é a mais comum. 


\section{Mansonia titillans Walker, 1848}

Tem tegumento torácico enegrecido, o escudo coberto por escamas bronzeadas misturadas a escamas claras, em sua porção anterior, palpo das fêmeas medindo $1 / 3$ do tamanho da probóscide; os tergitos abdominais são cobertos por escamas escuras, com elementos esbranquiçados e amarelados esparsos ou formando pequenos conjuntos triangulares ápico-laterais.

Ma. titillans é uma das espécies mais freqüentes no nosso país. Na verdade distribui-se amplamente do sul dos E.U.A. ao sul da América do Sul, incluindo as Antilhas. É oportunista, ataca qualquer ave ou mamifero, principalmente os de grande porte, a qualquer hora do dia ou da noite, mas é no crepúsculo que atinge seu pico de hematofagia. É exófila, mas pode ser encontrada dentro das casas, em pequenos números, atraídas pela luz artificial ou mesmo pelos hospedeiros, mas abandona prontamente o domicílio após o repasto. Contudo, se a casa estiver muito próxima ao seu criadouro a invasão do domicílio pode ocorrer constantemente.

Ma. titillans ocorre durante todos os meses do ano pois seus criadouros são decididamente perenes. Em algumas localidades, porém, tem sua densidade muito aumentada nos meses de menores pluviosidade e temperatura.

Foi encontrada portando vírus da encefalite venezuelana e de arbovírus de doenças febris, além de veicular ovos de Dermatobia hominis, causadora do berne (Forattini, 1965b; Lourenço-de-Oliveira et al., 1985; 1986; Lourenço-de-Oliveira \& Silva, 1985; Hervé et al., 1986).

\section{GÊNERO COQUILLETTIDLA DYAR, 1905}

São mosquitos de porte médio, com pernas de aspecto sarapintado a olho nu, muito agressivos e insistentes em picar. As escamas da asa são largas ou com tendência para tal; o escudo é geralmente ornamentado com escamas douradas, bronzeadas e claras, que formam linhas ou manchas simétricas. Os fêmures têm mancha ou anel claro subapical.

Depositam seus ovos em conjuntos com formatos de jangadas alongadas, que flutuam na superfície do criadouro.

São noturnos e crepusculares, zoofílicos e exófilos. Podem invadir as casas nas épocas de elevada densidade populacional. Como Mansonia, são ecléticos e oportunistas; picam as mais variadas vítimas, de dia ou à noite.

Suas espécies estão agrupadas em dois subgêneros, dos quais apenas o Rhynchotaenia ocorre no Brasil. Dentre suas espécies podemos destacar Cq. venezuelensis e Cq. chrysonotum, por serem as mais comuns.

Cx. venezuelensis (Theobald, 1912) distingue-se das demais Coquillettidia brasileiras por apresentar o escudo de tegumento marrom-avermelhado, ornamentado por escamas esbranquiçadas e douradas que formam manchas cingidas por escamas escuras; a asa tem as escamas claras restritas a algumas veias longitudinais anteriores, sendo as escamas das veias M e M1+2 totalmente escuras; veia costa e $R$ apresentando uma mancha de escamas brancas, bem alvas, 
próximo a base. Cq. chrysonotum difere de Cq. venezuelensis por apresentar tegumento torácico geralmente bem mais escuro e ter a veia costa destituida de mancha de escamas brancas, ao passo que a veia $R$ possui nítida e extensa linha dessas escamas (cobrindo a raiz e parte da base desta veia).

Ambas as espécies têm hábitos semelhantes aos citados para as Mansonia. São vetores potenciais de arboviroses, tendo sido encontradas naturalmente infectadas com esses agentes, inclusive com Oropouche ( $\mathrm{Cq}$. venezuelensis) (Forattini, 1965b; Hervé et al., 1986). Essas espécies de mosquito representam sério problema para os moradores das áreas próximas aos seus criadouros, pois são geralmente numerosas e muito agressivas.

\section{Tribo Orthopodomyiini}

Apresenta apenas um gênero:

\section{GENERO ORTHOPODOMYIA THEOBALD, 1904}

Suas características principais foram dadas nas chaves para identificação dos gêneros (p. 93 e 100).

Há apenas duas espécies desse gênero no Brasil: Or. albicosta (Lutz, 1904) e Or. fascipes (Coquillett, 1905).

As Orthopodomyia são quase sempre coletadas nas fases larvárias ou pupal, sabendo-se pouco sobre os hábitos dos adultos. A maioria das fêmeas capturadas no campo foram vistas pousadas sobre a água dos criadouros ou abrigadas nos ocos de árvore. Preferem o sangue de pássaros e recusam-se a sugar o homem. Seus ovos são depositados isoladamente ou em pequenos grupos e eclodem logo após o desenvolvimento embrionário, sem latência. Suas larvas vivem em recipientes naturais como os internodios de bambu e ocos de árvore, raramente em bromélia. Poucas vezes foram surpreendidas em recipientes artificiais.

Chave dicotômica para a identificação das Orthopodomyia e dados adicionais sobre sua biologia e distribuição podem ser obtidos em Lane (1953), Chapman (1965) e Zavortink (1968).

\section{Tribo Uranotaeniini}

Só o gênero Uranotaenia ocorre no Brasil e suas características principais foram dadas nas chaves citadas anteriormente (p. 93 e 100).

\section{GENERO URANOTAENIA LYNCH ARRIBALZAGA, 1891}

É um gênero de numerosas espécies que se distribuem principalmente no Velho Mundo. São mosquitos pequenos, poucas vezes atingindo porte médio.

Suas larvas têm cabeça estreita e escurecida e sifão curto. Quando estão obtendo ar na superfície permanecem quase paralelas a esta, fazendo com que 
os menos avisados as confundam com anofelinos. Suas formas imaturas vivem nas coleções líquidas no solo, ricas em vegetação, sombreadas e permanentes, como os charcos, alagados, pântanos, lagos, bolsões de rios e canais, ou mesmo menores e parcialmente sombreadas (valas de drenagem e poças, freqüentemente ricas em algas).

As fêmeas sugam animais de sangue frio, especialmente os anfíbios. São mosquitos muito atraídos pela luz, sendo por isso freqüentemente capturados em armadilhas luminosas e algumas vezes encontrados dentro do domicílio, porém não se interessando pelo sangue humano.

Alguns dados sobre a sistemática e biologia dos Uranotaenia podem ser encontrados em Remington (1945), Lane (1953), Galindo et al. (1954), Belkin et al. (1970) e Lourenço-de-Oliveira (1984).

\section{Tribo Sabethini}

É conhecida por compreender mosquitos geralmente muito bonitos, coloridos, metálicos e silvestres.

Estão agrupados nesta tribo os mosquitos que apresentam cerdas (e ds vezes também escamas) no mesoposnoto e que têm o mesomeron pequeno (mais estreito que a espessura do antepronoto), a sua margem superior estando em linha ou abaixo da base da coxa posterior. Em muitas espécies os antepronotos são desenvolvidos e aproximados na linha mediana (vista dorsal), podendo até estar quase encostados um no outro. Apresentam as cerdas torácicas geralmente reduzidas, principalmente no escudo. As cerdas pré-espiraculares estão presentes (exceto no gênero Limatus, em que são substituídas por escamas), enquanto as pós-espiraculares são ausentes. As antenas dos machos são geralmente semelhantes às das fêmeas e o comprimento do palpo também não costuma ser grande naqueles. Verifica-se que a separação dos sexos nos Sabethini só é segura quando se pesquisa a existência da genitália masculina externa.

É uma tribo quase inteiramente neotropical. Suas espécies são essencialmente silvestres, diurnas e geralmente pouco agressivas ou mesmo muito "inibidas". Os ovos são depositados isoladamente. As formas imaturas desenvolvemse exclusivamente em recipientes, quase sempre naqueles de caráter natural. Muitas espécies são acrodendrófilas e a maioria parece ser zoofílica, mas atacam o homem, na floresta ou ao seu redor.

A tribo é composta por 8 gêneros, que podem ser separados utilizando-se a chave apresentada atrás para os adultos. As formas imaturas, porém, foram insuficientemente estudadas para se compor uma chave.

\section{GENERO SABETHES ROBINEAU-DESVOIDY, 1827}

Os Sabethes são, indubitavelmente, os mais belos mosquitos. São dotados de colorido variado e de reflexos cintilantes. Seu escudo, pleura e abdome são intensamente recobertos por escamas que emprestam ao mosquito um aspecto metálico. 
Os antepronotos são desenvolvidos e quase se tocam na linha mediana (vista dorsal). As antenas e palpos são semelhantes nos sexos. As tíbias podem apresentar tufos de escamas longas que dão a esses apêndices a aparência de remos.

São mosquitos muito "tímidos", que sobrevoam muitas vezes a vítima antes de pousar, o que freqüentemente fazem sobre o rosto, particularmente no nariz. Voam lentamente, com as pernas posteriores voltadas para frente, em arco acima do tórax, e quando ameaçados, afastam-se do hospedeiro voando de costas, de ré.

São exclusivamente diurnos, silvestres, freqüentemente acrodendrofilos e criam-se em recipientes naturais, quase sempre em buracos de árvore, internódios de bambu e axilas de folhas.

Suas fêmeas grávidas são realmente adaptadas a desovar em recipientes cuja abertura para o meio externo é pequena: um orifício estreito. Neste caso, as fêmeas sobrevoam o local, aproximam-se do orifício e, voltando a ponta do abdome em direção à abertura, atiram 1 ou 2 ovos através dela. Podem continuar a desovar ali ou não.

Há cinco subgêneros em Sabethes: os espécimes que não apresentam cerdas proepisternais superiores e que podem ter as pernas hirsutas, com tíbias de aparência semelhante a pás de remo são os do subgênero Sabethes RobineauDesvoidy, 1827. Diferindo desses caracteres e apresentando tarsos medianos com marcação clara, temos as espécies do subgênero Sabethoides Theobald, 1903; aquelas possuindo cerdas prealares estão no subgênero Davismyia Lane \& Cerqueira, $1942 \mathrm{e}$ as de tarsos medianos escuros distribuem-se nos subgêneros $\mathrm{Sa}$ bethinus Lutz, 1904 (desprovidas de cerdas mesocatepisternais inferiores) e Peytonulus Harbach, 1991 (com estas cerdas). As espécies brasileiras desses subgêneros podem ser identificadas empregando-se as publicações de Forattini (1965b), Harbach \& Peyton (1990) e Harbach (1991). Dados adicionais podem ser obtidos em Lane \& Cerqueira (1942) e Lane (1953).

Uma espécie de Peytonulus - Sa. soperi Lane \& Cerqueira (1942) e uma de Sabethinus - Sa. intermedius (Lutz, 1904) têm demonstrado envolvimento na veiculação de arboviroses (Tucunduba e Macaua). Dentre os Sa.(Sabethes) temos Sa. belizarioi Neiva, 1908 e Sa. quasicyaneus Peryassu, 1922 que foram encontrados naturalmente infectados com arbovirus, inclusive causadores de encefalite ( $\mathrm{Sa}$. belizarioi com o tipo St. Louis, no Brasil) (Hervé et al., 1986).

A espécie de maior importância médica de Sabethes está no subgênero Sabethoides: Sa.chloropterus.

Sabethes chloropterus Humboldt, 1819

Diagnose. Os adultos têm cerdas proepisternais superiores e as tíbias não apresentam aspecto de remo; os tarsos medianos II-IV são brancos em um dos lados; o vértice é de tonalidade violácea ou azulada (mas não esverdeada); os antepronotos e o escudo são revestidos de escamas, com reflexos metálicos esverdeados ou azulados, que, dependendo da incidência da luz, podem se tornar dourados; as cerdas mesepimerais superiores são curtas, retas ou ligeiramente 
curvas, não atingindo com a sua extremidade a porção mediana do mesoposnoto; o tergito abdominal I é recoberto de escamas da mesma tonalidade que os demais, isto é, os tergitos são de reflexos metálicos azul-esverdeados, com elementos violáceos basalmente; há também áreas claras (amareladas ou brancoprateadas) basolaterais nos tergitos e os esternitos são claros.

Distribuição geográfica. Ocorre do México ao norte da Argentina e Sul do Brasil, incluindo Trinidad.

Está geralmente ligado à existência de florestas densas, quentes $\mathrm{e}$ úmidas.

Biologia. Cria-se em recipientes naturais permanentes, preferencialmente em ocos de árvore, principalmente naqueles grandes mas com abertura pequena para o exterior (o que prolonga a existência do líquido, protegendo-o da evaporação intensa). Os ovos são sensíveis à dessecação e são depositados da forma descrita antes para o gênero.

É um mosquito exclusivamente diurno e acrodendrófilo. Pica junto ao solo em condições semelhantes às descritas para $\mathrm{Hg}$. janthinomys. Sua acrodendrofilia é menos acentuada nas florestas mais abertas e menos úmidas.

Ocorre durante todo o ano, pois seus criadouros raramente secam completamente. Mas é na época das chuvas que sua população atinge os índices mais elevados. É essencialmente exófilo (silvestre) e eclético quanto ao hospedeiro, e ataca o homem com certa facilidade.

Relação com a transmissão de arboviroses. É vetor potencial da febre amarela silvestre. Ainda não foi encontrado naturalmente infectado pelo vírus amarílico no Brasil, mas o foi na América Central. Seus hábitos acrodendrófilos, sua susceptibilidade ao vírus e sua presença marcante em surtos desta arbovirose foram alguns dos motivos que levaram a suspeitas sobre sua participação como transmissor.

Arbovírus diferentes do amarilico já foram detectados em Sa. chloropterus coletados na natureza, como por exemplo os vírus da encefalite St. Louis e Ilhéus (Forattini, 1965b; Hervé et al., 1986).

\section{Outros Sabethini}

Os demais gêneros de Sabethini têm importância epidemiológica mais restrita, embora sejam vetores potenciais e às vezes comprovados de certos arbovírus. Contudo, desde que a identificação específica nesses gêneros é muitas vezes dificultada (pela falta de características constantes e diferenciais no sexo feminino), o isolamento viral é geralmente associado ao nome genérico. Com isso, pouco sabemos da participação de cada espécie no ciclo silvestre de tais agentes etiológicos.

Neste aspecto o gênero Wyeomyia Theobald, 1901, o mais numeroso em espécies entre os Sabethini, é o mais problemático. Após as últimas revisões (Lane \& Cerqueira, 1942; Lane, 1953), várias espécies foram descritas e/ou redescritas (ver Knight \& Stone, 1977; Knight, 1978; Ward, 1984), além do que muitas de suas fêmeas ainda não são separáveis morfologicamente. 
As Wyeomyia são, talvez, os Sabethini menos coloridos e os mais foscos, não apresentando aquele brilho metálico descrito para os Sabethes. São mosquitos silvestres, diurnos e, embora algumas espécies frequientem a copa da floresta, aparecem em sua grande maioria atacando junto ao solo. Criam-se em recipientes naturais, como bromélias, internódios de bambu, casca de frutos e axila de folhas de aráceas e de outras plantas. São ecléticos quanto aos hospedeiros e podem atacar o homem em grande número. São pouco agressivos, mas não tão "tímidos" quanto os Sabethes e os Limatus.

Há isolamentos de vírus de espécies de Wyeomyia, mas pouco se sabe sobre sua real importância (Forattini, 1965b; Hervé et al., 1986).

As Phoniomyia Theobald, 1903 têm o corpo dotado de reflexos metálicos (mas menos coloridos e intensos que os dos Sabethes) e são os Culicinae de probóscide mais longa (fina, com a porção distal envergada para baixo).

A maioria de suas espécies pode ser identificada usando-se as chaves propostas por Corrêa \& Ramalho (1956), pois apenas duas novas espécies foram descritas após esta publicação (Knight \& Stone, 1977; Lourenço-de-Oliveira et al., 1991).

Criam-se exclusivamente em bromélias, sendo raramente vistas em outro recipiente.

São geralmente mais comuns na estação chuvosa, mas ocorrem durante todo $o$ ano. Sugam o homem, mas no ambiente silvestre ou nas suas imediações, durante todo o dia, mas com picos de atividade hematofágica no final da tarde (logo antes do pôr-do-sol) e de manhã (Lourenço-de-Oliveira \& Silva, 1985; Lourenço-de-Oliveira et al., 1985; 1986; Forattini et al., 1986). São raros os isolamentos de vírus desses mosquitos (Aitken, 1960; Castro et al., 1991).

Os mosquitos do gênero Limatus Theobald, 1901 são de porte pequeno, muito bonitos, recobertos de escamas de reflexos metálicos e de tonalidades que variam do amarelado ao dourado, com manchas de cor avermelhada ou violácea. Há 4 espécies de Limatus que ocorrem no Brasil e que podem ser identificadas utilizando-se as chaves de Lane \& Cerqueira (1942) ou Lane (1953).

As fêmeas voam como os Sabethes, ou seja, são muito "tímidas". Atacam o homem e animais diversos com facilidade e, preferencialmente, junto ao solo. São diurnos e exófilos (silvestres), podendo ser encontrados criando-se e/ou picando no peridomicílio. Talvez sejam os Sabethini mais adaptados aos ambientes alterados pelo homem.

Suas larvas são vistas criando-se em recipientes naturais ou artificiais. Os primeiros são representados pelos internódios de bambu, buracos em árvore, axilas de folhas (bananeiras) e cascas de frutos. Aproveitam muito os criadouros artificiais, ou seja, os recipientes abandonados pelo homem na floresta, nas plantações ou mesmo no peridomicílio (geralmente próximo à mata), como latas de conservas e de bebidas e frascos de vidro ou de plástico. Larvas de Li. durhami Theobald, 1901 têm sido encontradas convivendo com as de Ae. aegypti ou Ae. albopictus.

Duas de suas espécies mais comuns - Li. durhami e Li. flavisetosus Oliveira Castro, 1935 - já foram achadas portando vírus no Brasil (Hervé et al., 1986). 
As espécies que até recentemente eram pertencentes ao gênero Trichoprosopon Theobald, 1901 (ver Lane, 1953), foram agrupadas em 4 gêneros: Trichoprosopon Theobald, 1901, Shannoniana Lane \& Cerqueira, 1942, Runchomyia Theobald, 1903 e Johnbelkinia Zavortink, 1979. Estes gêneros podem ser identificados, na fase adulta, utilizando-se a chave apresentada antes. Para a sua identificação nas fases imaturas e pela genitália masculina pode-se empregar as chaves propostas por Zavortink (1979).

Todos se criam em recipientes naturais, algumas vezes com águas ricas em matéria orgânica em decomposição e mal cheirosa. São em geral silvestres e diurnos. Os ovos são depositados em conjuntos em forma de jangada (ex. Tr. digitatum, see Lounibus, 1991) ou isoladamente (ex. Ru. magna).

As larvas de Trichoprosopon têm as mandíbulas modificadas, enquanto os outros três gêneros apresentam as maxilas modificadas. Tais alterações morfologicas parecem estar relacionadas com o hábito predatório facultativo exercido pelas larvas desses 4 gêneros.

Os Trichoprosopon criam-se em recipientes naturais variados, inclusive com água suja, rica em detritos e matéria orgânica em decomposição como, cascas de frutas em geral, especialmente em cacau e internódios de bambu.

Uma das espécies mais amplamente distribuída e mais comum (do México ao Estado de São Paulo, no Brasil) é Tr. digitatum (Rondani, 1848). É silvestre, mas pode ser encontrada, inclusive em elevados números, nos ambientes alterados pelo homem, como nas plantações e no peridomicílio, picando o homem e os animais domésticos (não aprecia o sangue de galinha e de animais de sangue frio). Pica durante todo o dia, mas acentua sua atividade hematofágica logo antes do pôr-do-sol, sendo um dos poucos Sabethini que ainda voam e picam durante o crepúsculo vespertino e quando já está escuro na floresta. Cria-se nos recipientes supracitados, principalmente em cascas de frutas e bambu. Está envolvido na veiculação de arbovírus (tipos Pixuna, Bussuquara, Wyeomyia e Ilhéus, dentre outros) (Zarvortink et al., 1983).

As Shannoniana parecem preferir criar-se em internódio de bambu. Seus adultos são diurnos, essencialmente silvestres e não têm relação conhecida com a veiculação de patógenos.

As Runchomyia parecem gostar de se criar em bromélias. As fêmeas são diurnas e silvestres, sendo que algumas espécies têm mostrado tendência à acrodendrofilia. Picam o homem e outros mamíferos com certa "timidez". Ru. frontos $a$ Theobald, 1903 é considerada vetor potencial possível da febre amarela silvestre no Brasil, pois é sensível ao vírus, acrodendrófila e dotada de certa antropofilia, embora nunca tenha sido encontrada naturalmente infectada (Davis, 1944; Forattini, 1965b; Hervé \& Travassos da Rosa, 1983).

As larvas de Johnbelkinia são normalmente achadas em axilas de folhas de plantas (aráceas, musáceas e bromélias) e em brácteas. Seus adultos são essencialmente diurnos e silvestres, e atacam o homem e outros animais com certa facilidade. Sabe-se que th. longipes (Fabricius, 1805) foi detectada com arbovírus fora do Brasil, mas se desconhece o real papel dessa e de outras Johnbelkinia como transmissoras de patógenos na natureza. 


\section{CONTROLE QUÍMICO E BIOLÓGICO: PERSPECTIVAS}

\section{CONTROLE QUÍMICO}

Anteriormente à descoberta dos inseticidas residuais sintéticos na década de 1940, diversas metodologias para o controle de mosquitos foram adotadas em diferentes partes do mundo com variados graus de sucesso. A bem sucedida campanha contra o Anopheles gambiae no Brasil nessa década, derivada de um contrato celebrado entre o Ministério da Educação e Saúde e a Fundação Rockefeller em 1939, foi realizada com a associação de várias medidas, destacando-se dentre elas o uso de piretro contra os adultos e de "verde-paris" contra as larvas (Soper \& Wilson, 1943).

A descoberta dos novos inseticidas revolucionou a metodologia de controle de mosquitos vetores de doenças, possibilitando a sua maior padronização. Pela primeira vez na história da saúde pública foi possível, em muitas regiões, controlar eficazmente e mesmo erradicar algumas das doenças por eles transmitidas. $\mathrm{O}$ uso de inseticidas sintéticos tem aumentado progressivamente desde então e presentemente continua sendo o principal suporte dos programas de combate e controle de insetos vetores de doenças (Wright, 1971; WHO, 1976; Mariconi, 1980).

Inseticidas organoclorados, organofosforados, carbamatos e piretróides têm sido empregados em várias regiões do mundo para o controle de mosquitos. No Brasil, o DDT (Dicloro-difenil-tri-cloro-etano) é ainda o inseticida químico mais largamente empregado para esse fim. Trata-se de um produto relativamente barato, com elevado poder residual, moderadamente tóxico e de baixa absorção cutânea; por outro lado não é biodegradável, sendo acumulativo nas gorduras de animais de sangue quente; pode interferir no metabolismo do sódio e potássio e mostrou-se carcinogênico em camundongos (Aldridge, 1979; Mariconi, 1980). Os equipamentos, técnicas de aplicação e estratégias de planejamento visando o controle de mosquitos encontram-se minuciosamente discutidos em AMCA (1968), WHO (1977) e WHO (1990). 


\section{Resistência a inseticidas}

A resistência de mosquitos ao DDT foi observada pela primeira vez na Flórida e na Califórnia em 1949 (AMCA, 1952) e disseminou-se amplamente a partir da década de 1950 . No início da década de 1980 já havia populações pertencentes a 84 espécies de culicíneos catalogadas como resistentes a inseticidas, muitas das quais apresentando resistência simultânea a vários inseticidas, incluindo importantes vetores de doenças (Georghiou, 1980; WHO, 1976; WHO, 1986).

A resistência de mosquitos pode classificar-se como:

1. Refratariedade. Quando toda a população, em função de suas características genéticas é imune ao inseticida.

2. Resistência adquirida. Surge em função da pressão seletiva exercida pelo emprego de inseticidas sobre a população. Pode possuir características de:

Resistência fisiológica. São selecionados na população de mosquitos, gens que a tornem significativamente refratária ou melhorem os seus mecanismos de desintoxicação aos produtos empregados.

Resistência comportamental. A população de mosquitos conserva a sua susceptibilidade intrínseca ao inseticida, porém muda o seu comportamento no sentido de evitar o contato com o inseticida (Forattini, 1962; WHO, 1976).

A racionalização do emprego de inseticidas, sua utilização rotativa e o seu uso integrado com medidas de controle físico e biológico, tem sido recomendada para diminuir os riscos de aparecimento ou agravamento de resistência em populações de vetores (Brown, 1986).

\section{Inseticidas químicos alternativos}

Numerosos produtos são continuamente pesquisados com o objetivo de oferecer alternativas no controle de mosquitos. Dentre esses destacamos:

a. Hormônios juvenis. A partir da década de 60 , muitos produtos que interferem ra pupação ou na emergência de adultos foram testados. Destes, o Methopreme (Altosid) é o mais conhecido. Formulações de liberação lenta garantem sua atividade por vários dias, e apresentam os mais elevados níveis de segurança em relação a outros organismos do que os larvicidas convencionais (Shaefer \& Mulla, 1980; Logan, 1990).

b. Inibidores da formação de quitina. Esses produtos interferem com o processo de muda, inibindo a formação de quitina. Quando larvas de mosquito são expostas a alguns desses compostos, morrem por ocasião da próxima muda. Um desses produtos, denominado "Dimilin" ou TH.6040, tem demonstrado eficácia em estudos de campo nos E.U.A. (Shaefer \& Mulla, 1980). 
c. Produtos de origem vegetal. Produtos de origem vegetal vêm sendo testados quanto às suas propriedades inseticidas contra mosquitos adultos e imaturos, como inibidores de crescimento, reprodução e oviposição ou como repelentes. Sukumar et al. (199l) apresentam uma ampla revisão sobre $o$ assunto. No Brasil, diversos derivados de vegetais têm mostrado atividade inseticida contra larvas de mosquitos e/ou influência sobre o seu comportamento de oviposição (Consoli et al., 1988a; Consoli et al., 1989).

\section{CONTROLE BIOLÓGICO}

Organismos capazes de parasitar ou predar mosquitos em suas várias fases evolutivas vêm sendo estudados há bastante tempo. Jenkins (1964) já menciona 220 predadores invertebrados de larvas de mosquitos entre rotíferos, celenterados, platelmintos, moluscos, anelídeos, crustáceos, aracnídeos e insetos. Chapmam (1974) amplia essa lista, incluindo vírus, rickétsias, bactérias, protozoários e fungos. Em vista das constantes dificuldades enfrentadas no controle de mosquitos com inseticidas químicos em função do surgimento de resistência, tem sido dada uma crescente importância aos agentes de controle biológico (WHO, 1981a; 1982; 1984). Em 1982 foi publicado um guia de campo para a identificação dos principais patógenos que acometem mosquitos e outros insetos de importância médica (Weiser, 1982); igualmente uma extensa revisão bibliográfica foi apresentada por Roberts et al. (1983). Um sumário das potencialidades dos principais agentes controladores, bem como a sugestão de uma lista de prioridades para pesquisa nessa área encontra-se descrita em WHO (1984). Em 1987, um guia sobre a metodologia recomendada para o isolamento, detecção e identificação de agentes de controle biológico foi igualmente publicado (WHO, 1987a). Apresentamos, a seguir, uma relação dos principais organismos que têm sido estudados como controladores biológicos de mosquitos, com algumas considerações sobre o seu potencial como tais:

\section{Virus}

A maioria dos vírus patogênicos para artrópodes vetores de doenças foi isolada inicialmente em espécies da ordem Diptera, principalmente larvas de mosquitos. Nenhum destes, entretanto, tem demonstrado um potencial promissor como agente de controle biológico em culicíneos (WHO, 1984).

\section{Bactérias}

Nesse grupo encontram-se os agentes de controle biológico de mosquitos mais utilizados em todo o mundo. As duas espécies mais estudadas e utilizadas como tais - Bacillus thuringiensis H-14 (Bacillus thuringiensis israelensis) e Bacillus sphaericus - possuem elevadas propriedades larvicidas. Ambas produzem endotoxinas protéicas, as quais, quando ingeridas pelas larvas atacam e destroem o seu epitélio do estômago (intestino médio), levando-as à morte. Não causam 
portanto infecções nas larvas que acometem. Ambas mostraram-se inócuas para grande número de organismos vertebrados e invertebrados (WHO, 1981, 1985; Shadduck et al., 1980; Sinegre et al., 1979; Rishikesh et al., 1983; Charles, 1987). B. thuringiensis $\mathrm{H}-14$ é eficiente contra espécies dos gêneros Aedes, Anopheles, Culex e até certo ponto contra Mansonia, sendo ainda ativo contra larvas de simulídeos. B. sphaericus mostrou-se especialmente eficaz contra larvas de Culex. No mercado internacional existem diversas formulações comerciais de produtos baseados em ambas as espécies de bactérias, cujo poder residual em geral é baixo, embora B. sphaericus usualmente apresente um potencial mais elevado de reciclagem na natureza. Tais produtos vêm sendo utilizados de forma crescente nos programas de controle integrado de mosquitos e simulídeos vetores de doenças em várias regiōes do mundo. Presentemente estão sendo desenvolvidas pesquisas no sentido de isolar linhagens brasileiras dessas espécies e tecnologia própria para a sua produção comercial (Zahner et al., 1990; Silva et al., 1991). A produção das toxinas características destas bactérias através de engenharia genética vem sendo estudada (WHO, 1987b).

\section{Protozoários}

Diversos microsporídeos, de transmissão transovariana, têm sido descritos em larvas de mosquitos, entretanto os esforços de efetuar a transmissão não têm sido bem sucedidos. Culicospora magna, Hazardia milleri, Nosema algerae e Vavraia culicis são algumas das espécies estudadas, mas não há perspectivas de sua utilização prática até o presente (WHO, 1984).

\section{Fungos}

Numerosos fungos tem sido pesquisados quanto ao seu potencial como controladores biológicos de mosquitos. Dentre os fungos imperfeitos têm sido abordados principalmente Culicinomyces clavosporus, Metarhyzium anisopliae e Tolypocladium cylindrosporum; entre os Zigomicetos destacamos Oomycete fungi, Leptolegnia sp e Lagenidium giganteum, além de numerosas espécies de Coelomomyces (Chytridiomiceto). Os problemas mais freqüentemente encontrados nesses estudos têm sido a baixa especificidade, a alta dosagem necessária e as dificuldades de cultivo "in vitro". Atualmente pesquisa-se a capacidade entomopatogênica de novas amostras de fungos isoladas de mosquitos brasileiros (Costa et al., 1991 a, b). L. giganteum parece ser a espécie mais promissora (WHO, 1979; WHO, 1984).

\section{Nematódeos}

Diversos nematódeos da família Mermithidae têm apresentado resultados positivos em experimentos visando o controle biológico de larvas de mosquitos, inclusive em condiçōes de campo (Brown et al., 1977; Petersen, 1978; Westerdahl et al., 1981). A dificuldade do cultivo in vitro tem limitado muito a produção em massa das diversas espécies. Dentre estas, Romanomermis culicivorax tem sido a espécie mais estudada (WHO, 1984). 


\section{Invertebrados predadores}

Dugesia dorotocephala (Turbellaria: Planariidae) foi bastante pesquisada na década de 1970, quanto a seu potencial predador sobre larvas de mosquitos. Demonstrou-se ser um predador voraz, eficiente em condições algo limitadas, porém pouco específico em relação aos organismos predados (WHO, 198lb). Em condições de laboratório Helobdella triserialis lineata (Hirudinea: Glossiphonidae) também mostrou eficácia no controle de formas imaturas de mosquitos (Consoli et al., 1984). Dentre os artrópodes, larvas predadoras do gênero Toxorhynchites (Culicidae) têm sido utilizadas com sucesso no controle de vetores da filariose bancroftiana no sul do Pacífico e sudeste da Ásia (Bailey et al., 1983; WHO, 1984). Belostoma micantulum (Hemiptera: Belostomatidade), mostrou-se, em condições laboratoriais, um eficiente predador de formas imaturas de mosquitos, especialmente nos seus últimos estágios ninfais (Consoli et al., 1989).

\section{Peixes}

Peixes predadores de formas imaturas de mosquitos estão entre os mais antigos e eficazes agentes de controle biológico utilizados e continuam sendo intensivamente pesquisados. Gambusia affinis, Poecilia reticulata, Oreochromis $(=T i-$ lapia) spilurus spilurus, Cyprinus carpio, Macropodus opercularis e Astronotus ocellatus são algumas espécies estudadas e/ou utilizadas para essa finalidade (Alio et al., 1985; Ikemoto et al., 1986; Castelberry \& Cech, 1990; WHO, 1984, 198la; Costa et al., 1987; Consoli et al.,1991). Atualmente procura-se enfatizar o uso de espécies autóctones que posșuam ciclo anual. A resistência a poluentes orgânicos e inorgânicos, bem como a inseticidas, constitui um requisito importante na avaliação de um possível agente de controle. 


\section{TÉCNICAS}

\section{COLETA DE ADULTOS COM CAPTURADORES À BASE DE SUCÇÃO}

Este é um dos métodos mais freqüentemente utilizados por sua simplicidade e economia. Existem vários modelos de capturadores, baseados no dispositivo inicialmente descrito por Buxton (1928). A Figura 31 mostra alguns dos tipos mais utilizados. Os insetos são sugados individualmente para um tubo ou recipiente de vidro ou outro material transparente, provido de uma tela fina em uma extremidade, a qual se liga uma mangueira para sucção ou bomba que gera uma pressão negativa. Os mosquitos assim capturados podem ser transferidos diretamente para recipientes mortíferos (contendo éter, clorofórmio, cianetos etc.) ou para gaiolas de transporte (Fig. 38), caso haja interesse de mantê-los vivos.
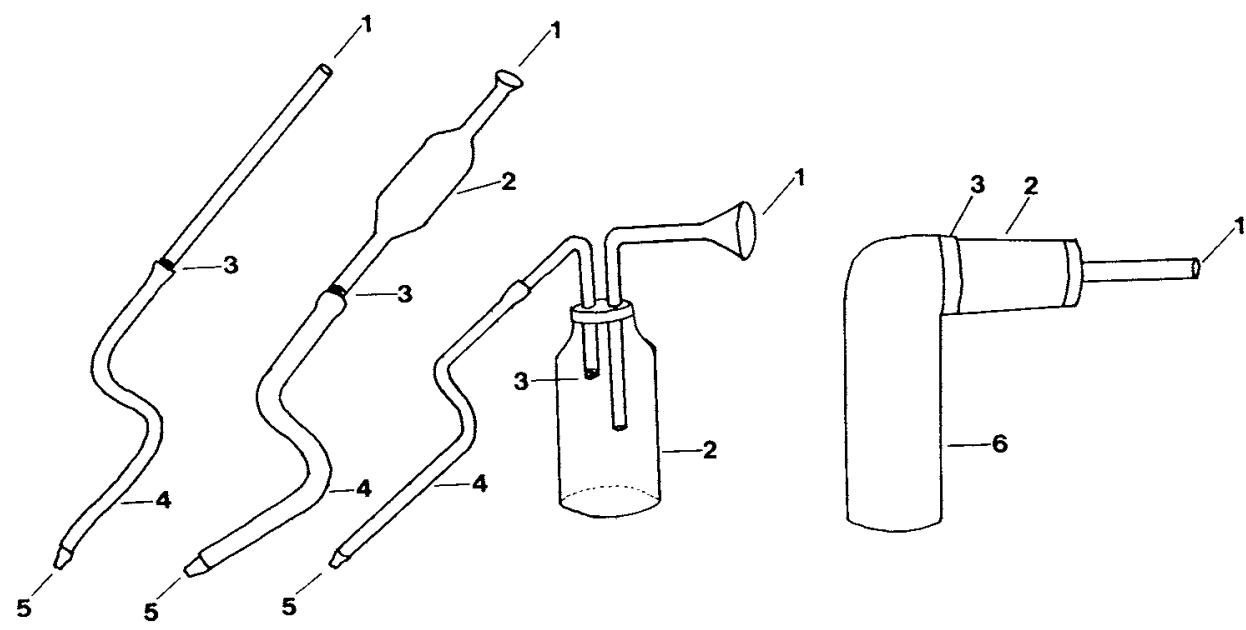

FiG. 31: Capturadores para adultos a base de sucção. 1: tubo coletor; 2: armazenador de mosquitos; 3: tela bloqueadora; 4: tubo flexível de borracha; 5: peça para sucção labial; 6: motor de sucção. 
Em levantamentos entomológicos de mosquitos de importância médica usa-se freqüentemente, como medida de densidade populacional, a expressão "coleta/homem/hora", correspondente ao número médio de insetos capturados por um indivíduo treinado durante uma hora. Embora essa medida seja inevitavelmente influenciada pelas diferenças individuais, é considerada válida quando é empregada com uma amostra de tamanho adequado. Com esse tipo de capturadores pode-se fazer capturas intra e extradomiciliares de mosquitos pousados sobre paredes, tetos, móveis, plantas, ou iscas humanas e de outros animais. A isca humana pode ser o próprio indivíduo que captura ou outra pessoa. O método de coleta com utilização de iscas pode ser associado ao uso de armadilha de Shannon e similares.

\section{COLETA DE ADULTOS COM ARMADILHA DE SHANNON E CORRELATAS}

Esta armadilha, descrita inicialmente por Shannon (1939), foi adaptada em suas medidas por diversos autores.

Consiste originalmente de uma estrutura de tecido branco e tela apropriada para a captura de mosquitos ao ar livre (Fig. 32). Pode-se utilizar, para atrair os insetos, uma fonte luminosa em seu interior, associada ou não a uma isca humana ou animal. Os mosquitos que voam para o seu interior são coletados com capturadores de sucção. Como variante desse método, podem ser montadas "tendas" de tecido fino, tipo filó, de vários formatos e tamanhos a cerca de $20 \mathrm{~cm}$ de altura do solo, providos de isca humana ou animal (Fig. 33) (WHO, 1962).

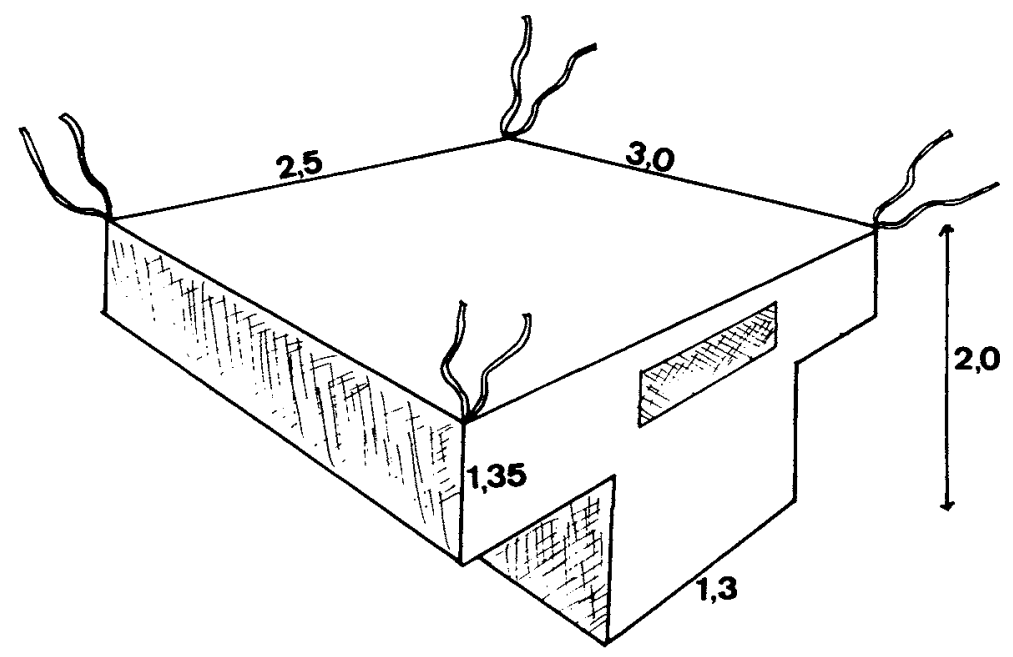

FIG. 32: Armadilha de Shannon, estando indicadas as dimensões originalmente descritas, em metros. 


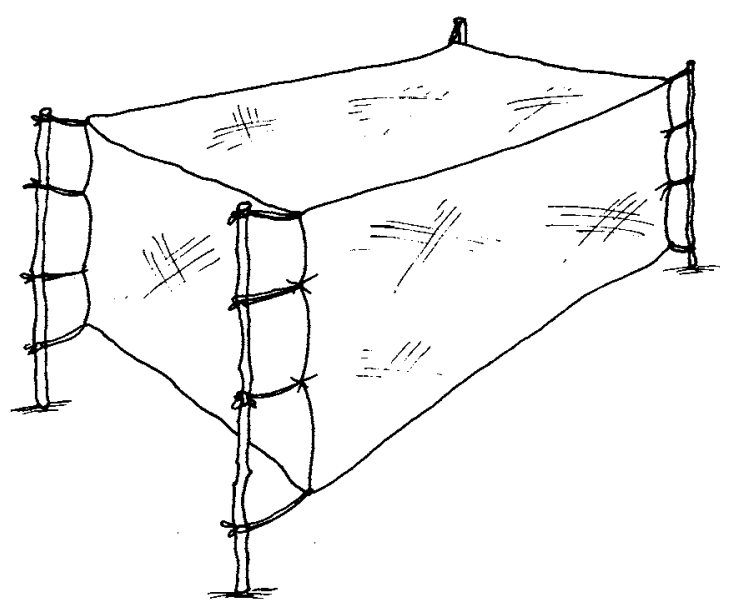

FIG. 33: Tenda de tecido fino, para captura de adultos.

\section{COLETA DE ADULTOS COM ARMADILHAS LUMINOSAS AUTOMÁTICAS}

Existem vários tipos e marcas de armadilhas automáticas baseadas na atração exercida por uma fonte luminosa comum ou de luz ultravioleta, junto a qual está instalada uma hélice cujo movimento aspira os mosquitos para um recipiente.

Podem conter ou não substâncias tóxicas, tais como inseticidas, gás carbônico, ou diversas substâncias atrativas (Mulhern, 1953; Morris \& De Foliart, 1969; Jewel, 1981). Os tipos "New Jersey" (New Jersey Agricultural Experiment Station, New Jersey, U.S.A.) e o "CDC" (Communicable Disease Center, Atlanta, U.S.A.) estão entre os mais utilizados (Fig. 34), existindo descritas numerosas variantes, inclusive versões bastante leves e práticas como a de Collier et al. (1992). O fato de nem todas as espécies de mosquitos serem atraídas uniformemente pela luz, deve ser levado em conta ao se recorrer a esses dispositivos para levantamentos faunísticos (WHO, 1962; Sudia \& Chamberlain, 1962).

\section{COLETA DE ADULTOS COM ARMADILHAS DE OVIPOSIÇÃO OU DE FÊMEAS GRÁVIDAS}

Diversas armadilhas têm sido desenvolvidas e produzidas comercialmente, baseadas na atração exercida por fatores físicos e químicos sobre as fêmeas grávidas que buscam um local para a oviposição. Tais armadilhas podem com- 


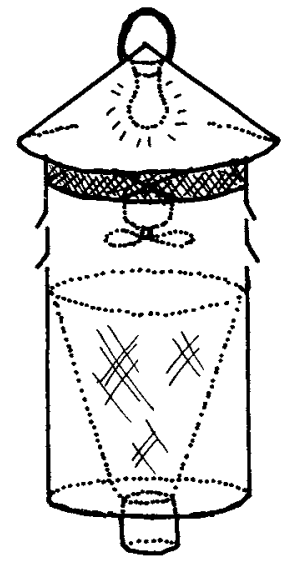

A

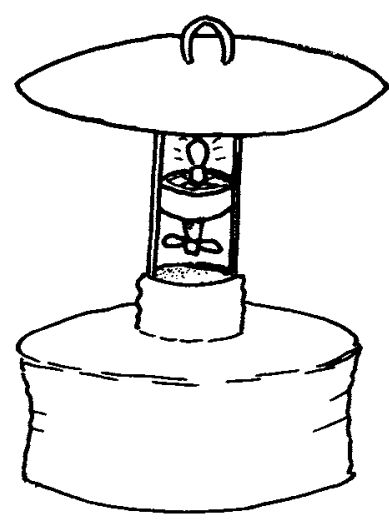

B

Fig. 34: Armadilhas luminosas para captura de adultos. A: Tipo "New Jersey"; B: Tipo "CDC".

parar-se favoravelmente às armadilhas luminosas (Leiser \& Beier, 1982), sendo ou não específicas quanto à espécie de mosquitos capturados (Tanner, 1969; Clark et al., 1982; Klooter et al., 1983). Nos estudos epidemiológicos, possuem a vantagem de, ao capturarem seletivamente fêmeas grávidas, incluírem naturalmente também um maior percentual de mosquitos infectados. Reiter (1983) descreveu um tipo eficiente e bastante utilizado, baseado na armadilha luminosa "CDC" miniatura, na qual a fonte luminosa é substituída por um recipiente de material plástico preto, contendo água à qual podem ser adicionados diversos produtos atraentes ( Tikasingh \& Laurent, 1981; Benzon \& Apperson, 1988; Bentley \& Day, 1989; Millar et al., 1992). Ao aproximar-se da superfície da água, a fêmea atraída é sugada para o recipiente superior da armadilha. Existem diversos modelos variantes, baseados nesse método, produzidos comercialmente.

\section{COLETA INTRADOMICILIAR DE ADULTOS COM AUXÍLIO DE INSETICIDAS}

Esse método presta-se para avaliar a densidade populacional e composição da fauna de mosquitos intradomiciliares de maneira rápida e eficiente. Se forem utilizados inseticidas residuais nos locais de captura, eventuais repetições poderão ficar inviabilizadas por tempo variável. Tal inconveniente poderá ser evitado empregando-se um produto não residual, como o piretro. Na casa ou cônıdo escolhido, fecham-se todas as portas e janelas e recobrem-se o assoalho e móveis com pedaços de tecido branco, de forma contínua. Com uma bomba 
manual ou aspersor ULV (aerosol), aplica-se prodigamente o inseticida no cômodo, começando por eventuais aberturas que possam permitir a fuga. Caso o número de aberturas seja grande, é aconselhável fazer simultaneamente a aplicação nas paredes externas, para formar uma barreira de inseticida contra escapes. Fecha-se o cômodo por cerca de 10 minutos, e decorrido esse prazo recoIhem-se os mosquitos mortos sobre as superfícies brancas com auxílio de pinças. Em casas pequenas, ocupadas por muitas pessoas, os quartos de dormir costumam ser os mais produtivos. Esse método tem sido extensivamente utilizado nos levantamentos entomológicos relacionados à malária na África (WHO, 1962).

\section{COLETA DE LARVAS COM CONCHAS}

É o método mais simples. Existem conchas de variados tamanhos e materiais: metálicos ou de materiais plásticos diversos, providos ou não com uma tela lateral para a eliminação do excesso de água. Podem possuir ainda uma escala volumétrica. Esse dispositivo é útil principalmente para coletas em criadouros maiores, devendo a sua forma e cabo serem adaptados a cada finalidade (Fig. 35). Campos \& Garcia (1993) descreveram um dispositivo que facilita a separação das larvas coletadas dos detritos e impurezas que possam estar presentes nas amostras.
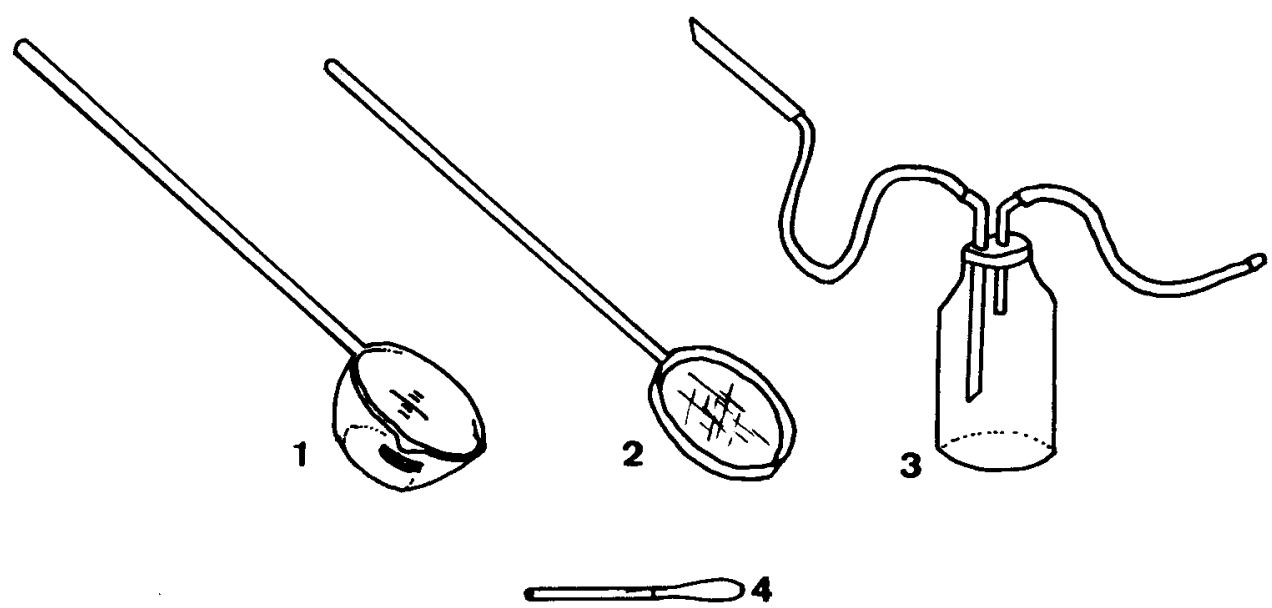

Fic. 35: Dispositivos para captura de larvas e pupas. 1: concha provida de escala volumétrica e tela lateral; 2: rede de malha fina; 3: sifão para coletar em criadouros pequenos ou de difícil acesso; 4: conta-gotas com abertura larga. 


\section{COLETA DE LARVAS COM REDES}

Redes com malhas finas (cerca de $0,3 \mathrm{~mm}$ ), com cerca de 20 a $30 \mathrm{~cm}$ de diâmetro, providas de um cabo de tamanho adequado ao local podem ser utilizadas para "varrer" a água logo abaixo da superfície (Fig. 35). As larvas, então, são lavadas da rede para outro recipiente. Este método permite coletar grande número de larvas em pouco tempo, e um cabo comprido permite o acesso a locais de outra forma difíceis. Zhen \& Kay (1993) descreveram uma rede apropriada para a coleta de larvas em pneus.

\section{COLETA DE LARVAS POR PIPETAGEM}

Para criadouros pequenos e/ou de difícil acesso, tais como bromélias, buracos de árvores, internódios de bambu etc., a pipetagem é o método mais indicado. Pode ser feita diretamente, com um dispositivo tipo "conta-gotas" ou indiretamente com utilização de um sifão (Fig. 35.3), ao qual pode ser adaptado uma pequena bomba de vácuo que substitui o processo de sucção bucal. Uma armadilha para coleta de larvas, utilizada com sucesso em Fortaleza, foi descrita por Kay et al. (1992).

\section{MEDIDAS QUANTITATIVAS DE LARVAS}

\section{Medidas por área de superfície}

Coloca-se uma armação em forma de "moldura", medindo por exemplo 1 metro quadrado, em um criadouro e recolhem-se todas as larvas encontradas dentro da mesma. Se o fundo do criadouro não for plano ou se houver vegetação irregular isso poderá interferir na precisão da medida.

\section{Medidas por volume da água}

\section{a. Por conchada}

É possível fazer um cálculo aproximado da quantidade de larvas, pré-estabelecendo um número de conchadas, correspondentes a um determinado volume de água, por criadouro e intervalo de tempo.

\section{b. Por bombeamento}

Pode-se bombear um determinado volume de água, contando-se ou estimando-se o número de larvas encontradas. Se a amostra de larvas capturadas for razoavelmente homogênea, pode-se estimar o seu número, ainda que relati- 
vamente grande, concentrando-as em uma proveta fina e previamente perfurada para permitir o escoamento da água e a retenção das larvas. Tendo-se apurado previamente o número médio de larvas que se acumulam por $\mathrm{ml}$, pode-se fazer uma estimativa do número de larvas capturadas. Para cada amostra de larvas com características diferentes, os cálculos do número acumulado que ocupa o volume de $1 \mathrm{ml}$ devem ser refeitos (Fig. 36).

Nenhum desses métodos, exceto a contagem individual, fornece dados com valor absoluto, o que deve ser levado em conta ao serem analisados os resultados (WHO, 1962).

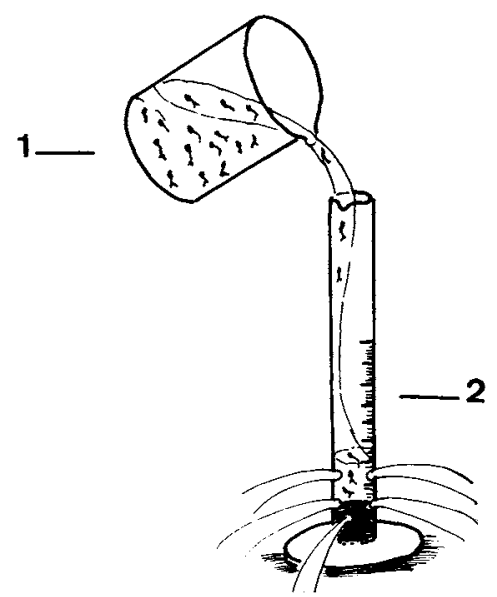

FIG. 36: Dispositivo para cálculo do número de larvas ou pupas. 1: Recipiente contendo formas imaturas em água; 2: Proveta perfurada, provida de escala volumétrica.

\section{TÉCNICAS DE TRANSPORTE}

Dependendo da finalidade a que se destinam, os mosquitos podem ser transportados vivos ou mortos para o laboratório.

\section{Mosquitos mortos}

\section{Adultos}

Por ocasião da captura são introduzidos imediatamente em tubos mortíferos que podem conter diversas substâncias letais: o cianeto de sódio misturado em gesso é muito eficiente, porém perigoso; éter, clorofórmio, acetato de etila ou tetracloreto de carbono, embora menos eficazes são mais seguros, e portanto mais recomendáveis (WHO, 1962). Para distâncias não muito grandes, podem-se transportar os mosquitos vivos para o laboratório e matá-los aí, colocando-os no 
"freezer" ou congelador. Após a morte, os adultos devem ser montados tão rápidamente quanto possível. A exposição de mosquitos recentemente mortos a vapores de acetona por algumas horas, antes da montagem, evita o colapso do abdome, cabeça e tórax, obtendo-se assim exemplares mais fáceis para estudar (Truman, 1968). Quando é necessário transportar mosquitos mortos e secos, não montados em alfinetes, é melhor fazê-lo em pequenos frascos individuais ou em tubos de ensaio estreitos nos quais se alternam os mosquitos com algodão e papel de filtro, adicionando-se um pouco de naftalina para melhor conservação. Caso se pretenda a utilização posterior desse material em testes envolvendo rádioimunensaio, deve-se substituir a naftalina por sílica-gel (Fig. 37).

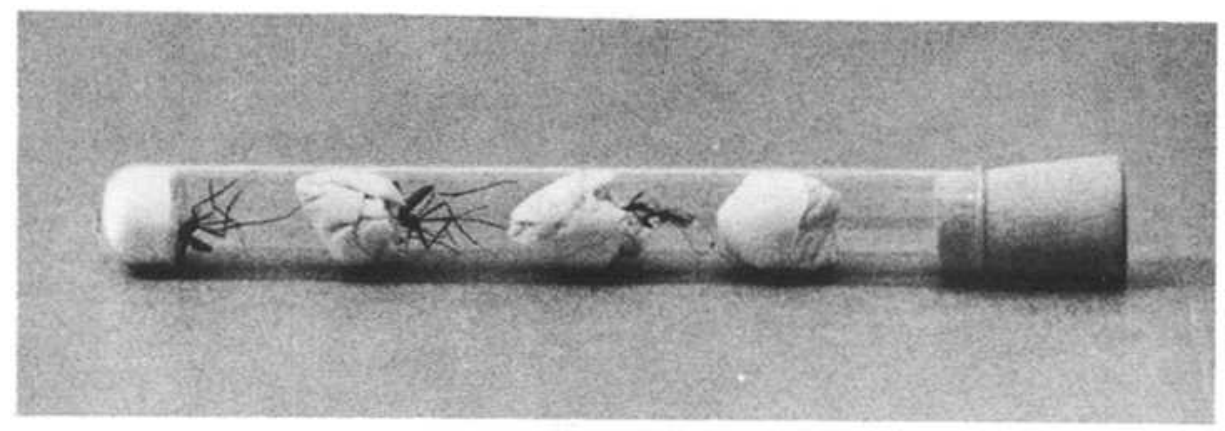

FIG. 37: Tubo para armazenar e transportar mosquitos adultos mortos.

\section{Formas Imaturas}

As larvas usualmente são preservadas em álcool $70 \%$ ou formol a $4 \%$ (Forattini, 1962). Para que não fiquem retorcidas, pode-se matá-las, mergulhando-as rapidamente em água quente, com auxílio de uma peneira.

\section{Mosquitos vivos}

\section{Adultos}

Seja com o objetivo de estudos de biologia, testes de susceptibilidade a inseticidas ou para posterior dissecção, os mosquitos vivos devem ser transportados com todo cuidado. As gaiolas de transporte (Fig. 38) devem ser colocadas em um recipiente tampado, de material isolante, como por exemplo "isopor" e cujo fundo esteja forrado com gaze e/ou algodão úmido, de maneira firme para evitar, ao máximo, as trepidaçōes. Sobre a tela de cada gaiola coloca-se um chumaço de algodão embebido em uma solução de glicose, frutose, sacarose ou mel para a alimentação dos mosquitos. 


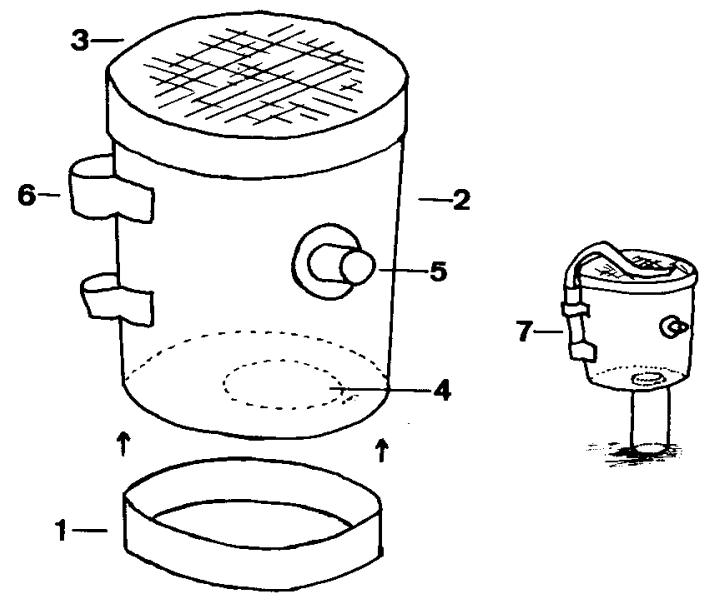

FiG. 38: Gaiola para transporte e manutenção de mosquitos vivos. 1: fundo encaixável; 2: gaiola de cartolina, pvc, materiais plásticos etc...; 3: tela de fina nailon; 4: abertura para encaixe de recipiente com água; 5: abertura para inserção de capturador; 6: alça suporte para recipiente com alimento açucarado; 7: montagem para manutenção de mosquitos vivos e obtenção de desovas.

Quando existe o interesse de se obter desovas de fêmeas capturadas, as gaiolinhas podem ser encaixadas sobre um recipiente com água (Fig. 38) possuindo, acopladas lateralmente, um tubo de ensaio contendo uma solução açucarada em contato com uma tira de papel de filtro, cuja ponta seja acessível aos mosquitos. No laboratório, esse conjunto deve ser colocado em local com temperatura e umidade compatíveis com a sobrevida das fêmeas e a salvo de formigas. Através da tela pode-se oferecer repasto sanguíneo em sangue humano (encosta-se a mão na tela), outros hospedeiros ou mesmo sangue citratado oferecido através de uma membrana (Consoli et al., 1983). No recipiente para a oviposição deve-se colocar preferencialmente a água colhida no campo, do criadouro (ou suposto criadouro) da espécie em questão. $\mathrm{Na}$ falta desta, deve-se usar água desclorada do local mais próximo possível daquele no qual foi feita a captura. Nem todos os mosquitos desovam facilmente em água destilada, devendo-se evitá-la por isso, sempre que possível.

\section{Formas Imaturas}

As larvas e pupas devem ser transportadas na própria água na qual foram coletadas, tendo-se o cuidado de deixar um espaço com ar nos frascos. Por períodos não muito longos, pode-se transportá-las em papel de filtro úmido. Esse também é o processo habitual para o transporte de ovos vivos, havendo diversas técnicas adicionais descritas (Deane \& Causey, 1943; Sayer \& Davidson, 1981). 


\section{TÉCNICAS DE MONTAGEM}

\section{Montagem em alfinetes entomológicos}

Esse é o processo habitual para montagem de adultos:

\section{Montagem com Triângulos de Cartolina}

Um pequeno triângulo de cartolina branca é colocado em um alfinete entomológico com auxílio de um suporte de madeira ou cortiça perfurado, o que garantirá a altura padronizada do mesmo (Fig. 39.a). Coloca-se então uma pequena gota de cola transparente ou esmalte de unhas incolor sobre uma superficie clara e embebe-se a ponta livre do triângulo em uma pequena quantidade da mesma. A seguir encosta-se com cuidado essa ponta na pleura torácica do mosquito que vai ser montado, de maneira que a maior parte das pernas fique posicionada na direção do alfinete. Levanta-se o alfinete já com o mosquito aderido, e com um estilete fino faz-se as correções na sua posição antes que a cola seque. O mosquito deve ficar deitado lateralmente sobre o triângulo, apresentando a pleura torácica superior livre para a observação (Fig. 39.b, c). As etiquetas (uma com os dados da coleta - quem coletou, local e data - e outra com u nome da espécie, quem determinou e data) somente devem ser colocadas apos a total secagem da cola, devendo ser também colocadas em alturas padronizadas. Podese ainda proceder montagens duplas, com utilização de microalfinetes (WHO, 1962; Forattini, 1962). Os exemplares montados devem ser conservados em caixas ou gavetas entomológicas adequadas, em locais arejados. A pintura interna das caixas com uma solução de naftalina em creosoto de faia ajuda a impedir o ataque de pragas.

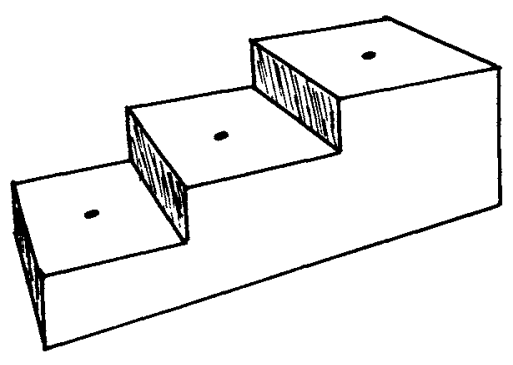

a

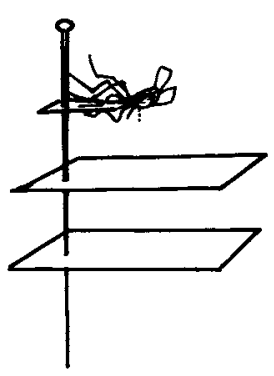

b

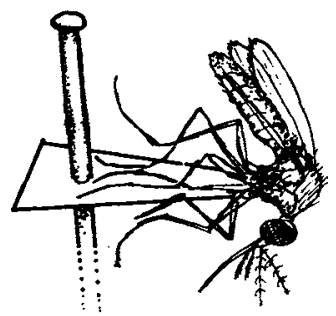

C

FIG. 39: Montagem de mosquito adulto em alfinete. a: Dispositivo para padronizar a altura de triângulos e etiquetas para a montagem de adultos. b: Adulto montado. c: Posição do adulto no triângulo. 


\section{Montagem em lâminas}

As genitálias masculinas, larvas, ovos e exúvias larvais e pupais são habitualmente montadas em lâminas. A montagem de adultos completos em lâminas não é adequada a um estudo minucioso. Entretanto, devido a sua maior resistência, tais montagens podem ser muito úteis como material didático em cursos de nível mais elementar, onde apenas as características gerais de algumas subfamílias são abordadas.

Existem numerosas técnicas de montagem descritas (Christophers, 1960; Forattini, 1962; WHO, 1962), por vezes, diferenciadas para as diversas estruturas. A técnica descrita a seguir é bastante abrangente, prestando-se para a montagem das várias formas mencionadas. Os tempos apresentados são médios e devem ser flexibilizados de acordo com o material a ser montado, e depois transferido de um recipiente para outro com auxílio de um pincel fino ou pedaço de papel de filtro. Quanto mais quitinizado for o material tanto maior deve ser a sua permanência em cada um dos vários meios. Detalhes para a montagem de genitália masculina são dados por Causey et al. (1946).

1. Clarificação A - solução de $\mathrm{KOH}$ a $10 \%$, fria, durante 12 horas (apenas para materiais fortemente quitinizados como larvas e genitália masculina); não usar pincel.

2. Desidratação - álcool $70 \%$ - 15 minutos

- álcool 80\% - 15 minutos

- álcool 90\% - 15 minutos

- álcool 95\% - 10 minutos

- álcool absoluto - 10 minutos

3. Clarificação B - creosoto de faia -24 horas.

4. Montagem

- com bálsamo do Canadá, entre lâmina e lamínula.

5. Secagem

- preferencialmente em estufa, a $40-45^{\circ} \mathrm{C}$, o que favorece a eliminação de eventuais pequenas bollhas de ar.

As exúvias de larva e de pupa devem ser processadas a partir da etapa 2 (desidratação).

\section{TÉCNICAS DE DISSECÇÃO}

As técnicas de dissecção do sistema digestivo e glândulas salivares de fêmeas são utilizadas rotineiramente na avaliação da taxa de infecção malárica em populações de mosquitos. A dissecção de ovários e ovariolos serve para a determinação da paridade, sendo portanto essencial a avaliação da idade fisiológica em nível populacional, o que por sua vez constitui um dado importante na de- 
terminação do potencial vetorial de uma população de mosquitos. Tais técnicas têm sido descritas por numerosos autores, em diferentes espécies e mosquitos, com pequenas variações (WHO, 1962; Detinova, 1962).

\section{Dissecção do sistema digestivo}

1. Mata-se a fêmea colocando-a por 10 a 15 minutos no "freezer" $\left(-18^{\circ} \mathrm{C}\right)$; na falta deste pode-se recorrer a um jato de gás carbônico ou colocá-la em tubo mortífero, como descrito anteriormente.

2. Coloca-se o mosquito, com o ventre para cima, sobre uma lâmina limpa, em uma pequena gota de solução de $\mathrm{NaCl}$ a $0,9 \%$.

3. Na lupa, e com auxílio de pinças finas ou estiletes, removem-se asas e pernas, para faciliar o trabalho. Com um estilete faz-se um pequeno corte no tegumento do $7^{\circ}$ segmento.

4. Segurando o tórax com um estilete na mão esquerda, sem apertar em excesso, traciona-se lenta e gradativamente a extremidade do abdome com o estilete na mão direita, extraindo assim o sistema digestivo até o estômago.

5. Isola-se o estômago, removendo as demais estruturas com os estiletes, acrescentando-se um pouco mais da solução salina, se necessário.

6. Monta-se o estômago, cobrindo-o com uma lamínula, e observa-se ao microscópio.

\section{Dissecção das glândulas salivares e detecção de esporozoítos}

1. Segue-se a técnica anterior até o o item 2, sendo opcional a remoção de asas e pernas.

2. Observando na lupa, com um estilete na mão esquerda segura-se o mosquito pelo tórax, não muito próximo à cabeça e com um estilete na mão direita puxa-se lentamente a cabeça, extraindo assim as glândulas salivares.

3. Caso a cabeça se separe sem a extrusão das glândulas, pode-se ainda enxugar a área usando um pedaço de papel de filtro e, a seguir, pressiona-se suavemente o tórax com o estilete da mão esquerda, procurando simultaneamente alargar com o estilete da mão direita a abertura do cerviz, onde estava ligada a cabeça. Obtida a extrusão, acrescenta-se novamente uma gota da solução salina.

4. Após a remoção das demais estruturas, monta-se com lamínula e uma gota de solução salina e observa-se ao microscópio.

É possível também extrair as glândulas salivares por compressão do mosquito decapitado e desprovido de asas e pernas em solução salina (Barber \& Rice, 1936), embora alguma prática seja necessária para separá-las das demais estruturas. Pode-se ainda extrair esporozoítos das glândulas salivares recorrendo à centrifugação em vez de dissecção (Ozaki et al., 1984). 
Conforme mencionado no item Anofelinos relacionados com a transmissão da malária, p.(83), não é possível, através desta técnica, identificar a espécie dos esporozoítos que estejam infectando as glândulas salivares. Contudo, isto se tornou possível a partir do emprego das técnicas imunológicas propostas por Zavala et al. (1982), Burkot et al. (1984) e Beier et al. (1991), com as quais torna-se desnecessário recorrer a esta dissecção ou pode-se identificar os esporozoítos removidos em dissecção.

\section{Dissecção de ovários e ovaríolos} nova (1962).

A técnica aqui resumida encontra-se minuciosamente descrita por Deti-

\section{OVARIOS}

1. Coloca-se a fêmea anestesiada ou recentemente morta sobre uma lâmina limpa, com o ventre virado para cima, perto de uma pequena gota de solução fisiológica.

2. A ponta de um estilete fino é colocado firmemente sobre o $7^{\circ}$ ou $8^{\circ} \mathrm{seg}$ mento, e um segundo estilete colocado sobre o tórax do mosquito exercerá uma contínua tração para cima.

3. À medida que as vísceras forem surgindo, ficarão aderidas a superfície seca do vidro, facilitando a extração do trato genital intacto.

4. A gota de salina é levada até os ovários, logo após a sua extração.

5. Os ovários devem ser lavados em água destilada para se evitar a posterior cristalização do $\mathrm{NaCl}$.

6. Deixam-se secar os ovários, à temperatura ambiente, de forma que fiquem inflados com ar, o que é necessário para se visualizar bem as terminações das traquéolas. Para uma boa visualização, os ovários devem estar no máximo no estágio II de desenvolvimento. O material assim preparado não necessita ser examinado imediatamente, podendo ser guardado por muito tempo.

7. Examinar ao microscópio com aumento médio. As fêmeas nulíparas terão as extremidades das traquéolas ovarianas enoveladas, enquanto que aquelas que já realizaram uma ou mais posturas - oníparas (Forattini, 1962) - apresentarão as mesmas traquéolas distendidas (Fig. 40).

\section{OVARfOLOS}

O número de dilatações (relíquias ovariolares) encontradas nos pedículos terminais dos ovaríolos corresponde ao número de ovos anteriormente produzidos por este ovaríolo (Fig. 13.b). Como nem todos os ovariolos entram em atividade a cada ciclo gonotrófico, deve-se examinar o maior número possível de ovaríolos ( $\mathrm{n}^{\mathrm{Q}}$ mínimo de 6), correspondendo o maior número de dilatações encontradas à idade fisiológica da fêmea dissecada. É necessário cuidado para não 
confundir porções do cálice ovariolar, que podem desprender-se do oviduto, com verdadeiras relíquias.

1. Segue-se a técnica anterior até o item 4, removendo-se da lâmina todas as estruturas, exceto os ovários.

2. Com auxílio de estiletes muito finos remove-se gradativamente a membrana que envolve o ovário, o que promove a separação dos ovaríolos.

3. Segurando o ovário pelo oviduto interno, traciona-se levemente um ovaríolo, com o outro estilete, esticando o seu pedículo.

4. Faz-se a contagem do número de dilatações encontradas (Fig. 13.c).
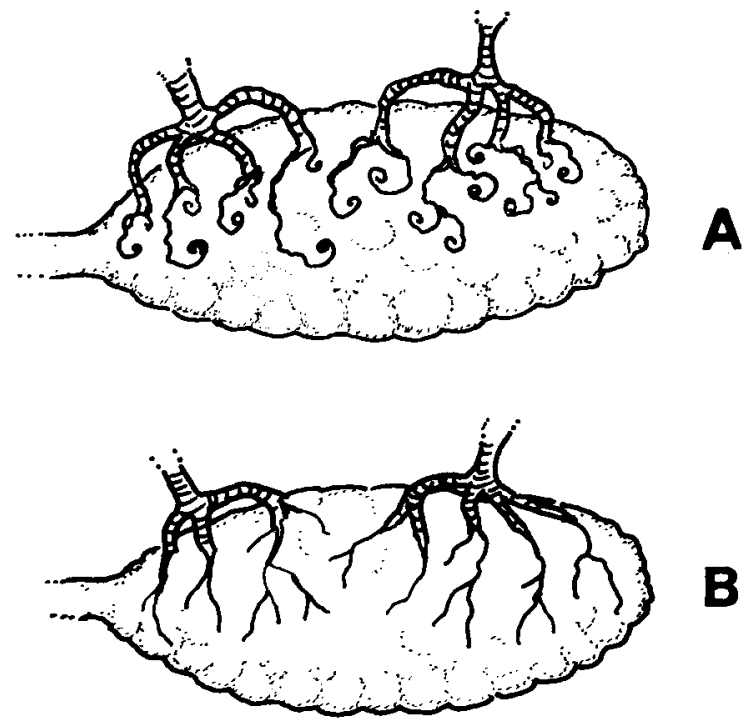

Fig. 40: A: Ovário nulíparo, mostrando extremidades traqueolares enoveladas. B: Ovário oníparo, apresentando estas extremidades distendidas.

\section{TÉCNICAS IMUNOLÓGICAS PARA A DETECÇÃO DE INFECÇÃO PLASMODIAL EM ANOFELINOS}

Esses imunensaios foram desenvolvidos na década de 1980, primeiramente por Zavala et al. (1982), com a finalidade de permitir a identificação da espécie de plasmódio que está infectando anofelinos capturados em áreas endêmicas e testados, à distância, tempos depois de sua coleta. 
As técnicas utilizadas se baseiam na deteç̧ão de antígeno correspondente ao epitopo repetitivo da proteína CS (circunsporozoíto) por anticorpos monoclonais. A proteína CS é específica de estágio (esporozoíto) e de espécie de plasmódio e, quando presente no extrato do anofelino testado, reage com o anticorpo monoclonal correspondente. Essa reação é revelada pelo mesmo anticorpo monoclonal marcado com Iodo ${ }^{125}$, no caso de radioimunensaio (IRMA), ou por uma enzima, como a peroxidase, no caso de teste imunenzimático (ELISA).

Os anofelinos coletados no campo e destinados aos imunensaios podem ser mortos com vapores de clorofórmio, éter, acetato de etila ou a baixa temperatura e mantidos bem desidratados até a realização dos testes. Isso pode ser conseguido transferindo-se os mosquitos mortos para frascos contendo camadas sobrepostas de papel filtro, algodão hidrófilo e sílica-gel. Pode-se manter os insetos mais protegidos da hidratação, acondicionando esses frascos em dessecador, bem vedado, contendo sílica-gel. Há no mercado sílica-gel com indicador de umidade, isto é, a sílica tem cor azul escura quando bem desidratada, tornando-se rósea ou menos colorida, quando já absorveu muita umidade. Neste caso, é melhor trocar a sílica ou reaproveitá-la, desidratando-a através de aquecimento. Não se devem colocar muitos mosquitos por frasco (usam-se até 50 exemplares em frasco do tamanho dos empregados para proteger filmes fotográficos $135 \mathrm{~mm}$ ).

Os anticorpos monoclonais utilizados nos imunensaios aqui descritos são produzidos em hibridomas e os detalhes da sua obtenção podem ser conseguidos, por exemplo, em Zavala et al., (1982) e Cochrane et al., (1984). Anticorpos monoclonais contra a proteína CS dos plasmódios humanos, e suas variantes, que ocorrem no Brasil, podem ser obtidos no mercado.

É preferivel submeter aos imunensaios apenas a cabeça e a porção anterior do tórax do anofelino. Teremos, assim, grande possibilidade de, no caso de um anofelino positivo, estarmos detectando proteínas CS procedentes de esporozoítos que se achavam albergados nas suas glândulas salivares. Se incluirmos o abdome do anofelino, onde a maior parte do estômago do inseto está alojada, poderemos detectar proteínas CS procedentes de oocistos maduros. É bom lembrar que um anofelino só pode ser incriminado como vetor de malária se for capaz de conduzir esporozoítos viáveis em suas glândulas salivares.

\section{Radioimunensaio (IRMA)}

A marcação dos anticorpos monoclonais pelo Iodo ${ }^{125}$ pode ser efetuada de acordo com a técnica preconizada por Fraker \& Speck (1978), ou modificada conforme a seguir:

Os anticorpos monoclonais podem ser marcados pelo $\mathrm{I}^{125} \mathrm{em}$ pequeno tubo de ensaio de vidro contendo $25 \mu \mathrm{g}$ de iodogen sólido $(1,3,4,6$-tetracloro-3a,6a-difenilglicoril, Sigma), obtidos a partir da evaporação (em banho-maria a $37^{\circ} \mathrm{C}$ ) de $250 \mu$ de uma solução de $1 \mathrm{mg}$ de iodogen $/ \mathrm{ml}$ de clorofórmio, diluída 100 vezes.

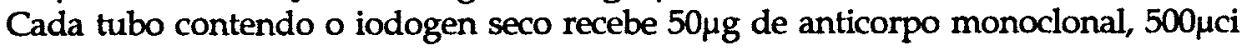


de $\mathrm{NaI}^{125}$ e $5 \mu \mathrm{l}$ de tampão fosfato $0,25 \mathrm{M}$. O tubo deve ser incubado em banho de gelo, no escuro, por $20 \mathrm{~min}$, sofrendo leve agitação a cada $5 \mathrm{~min}$.

Essa solução é passada através de uma coluna de Sephadex G25, para a separação dos anticorpos marcados com $\mathrm{I}^{125}$ do radionuclídeo livre. A coluna deve ser preparada com $6 \mathrm{~g} / \mathrm{ml}$ de gel, previamente hidratado por três horas à temperatura ambiente, tamizada, desgaseificada, empacotada com $8 \mathrm{ml}$ da resina supracitada, em uma pipeta plástica de $10 \mathrm{ml}$. Após sua montagem, a coluna é tratada com uma solução de PBS (solução salina tamponada) com 1\% de soro albumina bovina (BSA).

A eluição é feita com PBS, colhendo-se 15 frações de 1ml. Uma amostra de $1 \mu$ le cada uma das frações eluídas é contada em um aferidor de radiação gama. As frações referentes ao primeiro pico de radioatividade geralmente correspondem aquelas contendo anticorpos marcados com $\mathrm{I}^{125} \mathrm{e}$, por isso, devem ser aproveitadas para os testes, ao passo que as demais, contendo quase somente radionuclídeo livre, devem ser desprezadas.

\section{PROCESSAMENTO DOS ANOFELINOS}

\section{Preparação da placa para o teste}

As placas para o exame dos mosquitos devem ser preparadas de acordo com o protocolo a seguir:

a. Adicionar $50 \mu \mathrm{l}$ de uma solução contendo anticorpo monoclonal numa concentração de $10 \mu \mathrm{g} / \mathrm{ml}$ em PBS, em cada um dos 96 poços com fundo em "U" de uma placa flexível de polivinil.

b. Incubar a placa durante uma noite (por 12 a 16 horas) à temperatura ambiente.

c. Lavar cada poço da placa três vezes com uma solução de PBS com $5 \%$ de leite em pó desnatado ou BSA e incubar na mesma solução, porém contendo $5 \%$ de soro de cabra ou humano normal, por uma hora, à temperatura ambiente, a fim de saturar os sítios da placa não sensibilizados pelos anticorpos monoclonais na etapa (a).

d. Remover esta solução de bloqueio (PBS/leite/soro de cabra) exatamente antes da etapa $(\mathrm{g})$ abaixo.

\section{Processamento e teste dos mosquitos}

a. Colocar cada anofelino em um poço com fundo em "U" de uma placa rígida de poliestireno (ou em um tubo Eppendorf).

b. Adicionar, em cada poço (ou tubo) contendo mosquito, $50 \mu 1$ de uma solução de PBS com $1 \%$ BSA, contendo $0,5 \%$ do detergente Nonidet $P-40$ e inibidores de protease [antipaina e leupeptina a uma concentração final de 
$25 \mu \mathrm{g} / \mathrm{ml}$ e aprotinina a uma concentração final de $1,7 \mathrm{TIU} / \mathrm{ml}$ (unidades inibidoras de tripsina)].

c. Incubar os mosquitos nesta solução, por uma noite, em freezer $-20^{\circ} \mathrm{C}$, o que facilitará sua fragmentação na etapa (d).

d. Triturar cada mosquito com pequeno pilão apropriado para as dimensões dos poços da placa (ou do fundo do tubo Eppendorf). Para isso, pode-se acoplar uma pérola ao ápice de um bastão, ambos de vidro, ou dilatar a ponta de pipeta Pasteur com calor. Cada anofelino deve ser triturado com um pilão, o qual só deve ser reutilizado após ser bem lavado e seco.

e. Acrescentar ao extrato do mosquito $130 \mu \mathrm{l}$ da solução PBS com 1\% de BSA (volume final do extrato de mosquito $=180 \mu \mathrm{l}$ ).

f. Misturar bem e deixar sedimentar.

g. Adicionar $30 \mu \mathrm{l}$ do extrato de cada mosquito em cada um dos poços da placa flexível preparada no dia anterior. Os $150 \mu l$ restantes de extrato do anofelino devem ser congelados.

h. Incubar por duas horas à temperatura ambiente.

i. Lavar três vezes com PBS/leite (ou PBS/BSA).

j. Aspirar o PBS/leite e adicionar, imediatamente, 30 $\mu$ l de uma solução do anticorpo monoclonal marcado com Iodo ${ }^{125}$ ( $1 \times 105 \mathrm{cpm}$ por poço) em PBS contendo $10 \%$ de soro de cabra (ou soro humano normal).

1. Incubar por uma hora à temperatura ambiente.

m. Lavar quatro vezes cada poço com PBS contendo 0,05\% de Tween 20 (Sigma).

n. Secar bem e contar em contador Gamma.

Em cada radioimunensaio se estará testando o anofelino para apenas uma espécie plasmodial, utilizando-se $30 \mu l$ do seu extrato.

Cada imunensaio requer alguns controles (4-6) negativos (anofelinos nascidos em laboratório, sabidamente negativos, ou anofelinos infectados com espécie de plasmódio diferente daquela para qual o teste está sendo feito) e positivos (mosquitos com resultado fortemente positivo em ensaios anteriores, suspensão de esporozoítos da espécie plasmodial que se pesquisa [obtidos por dissecção de anofelinos infectados experimentalmente], ou solução (até $10 \mu \mathrm{g} / \mathrm{ml}$ ) de um peptídeo sintético, contendo quatro ou mais repetiçōes da seqüência de aminoácidos correspondente ao epitopo dominante da proteína CS da espécie plasmodial que se pesquisa).

Há vários critérios para considerarmos um anofelino como positivo em um radioimunensaio. Um deles é considerar positivo o extrato do anofelino que apresente contagem maior que o dobro daquela mais alta dentre os controles negativos. Este critério foi adotado por Cochrane et al., (1984), Arruda et al., (1986) e Subbarao et al., (1988). Contudo, há autores que preferem considerar positivo o anofelino que tiver contagem superior ao resultado da soma de dois ou três desvios padrões à média dos controles negativos (Oliveira-Ferreira et al., 1990). 


\section{ELISA}

O processamento dos anofelinos se dá de modo muito semelhante ao exposto acima para o IRMA.

\section{Preparação da placa para o teste}

a. Adicionar $50 \mu \mathrm{l}$ de uma solução contendo anticorpo monoclonal numa concentração de $10 \mu \mathrm{g} / \mathrm{ml}$ em PBS, em cada um dos 96 poços com fundo em "U", ou fundo chato, de uma placa rígida de poliestireno.

b. Incubar a placa durante uma noite (por 12 a 16 horas) à temperatura ambiente.

c. Lavar cada poço da placa três vezes com uma solução de PBS com $0,5 \%$ Nonidet $\mathrm{P}-40$ e incubar com $300 \mu \mathrm{l}$ da mesma solução, porém contendo 3$5 \%$ de leite em pó desnatado (ou BSA), por uma hora, à temperatura ambiente, a fim de saturar os sítios da placa não sensibilizados pelos anticorpos monoclonais na etapa (a).

d. Remover esta solução de bloqueio exatamente antes da etapa (g) abaixo.

\section{Processamento e teste dos mosquitos}

a - f. Preparar os anofelinos do mesmo modo citado nas etapas (a) até (f) do item sobre processamento e teste dos mosquitos para o IRMA. Contudo, pode-se aumentar o volume final do extrato do anofelino [item (e) do IRMA] até $300 \mu$ l utilizando-se PBS/leite, com 0,5\% de Nonidet P-40.

g. Adicionar $50 \mu \mathrm{l}$ do extrato de cada mosquito em cada um dos poços da placa preparada no dia anterior.

h. Incubar por duas horas à temperatura ambiente.

i. Lavar três vezes com PBS/0,5\% Nonidet P-40.

j. Aspirar o PBS/Nonidet e adicionar, imediatamente, $50 \mu 1$ do anticorpo monoclonal marcado com peroxidase (conjugado), diluído até $10 \mu \mathrm{g} / \mathrm{ml}$ de PBS contendo 3\% de leite desnatado.

1. Incubar por uma hora à temperatura ambiente.

m. Lavar três vezes cada poço com PBS contendo 0,05\% de Tween 20 (Sigma) ou $0,5 \%$ de Nonidet P-40.

n. Adicionar $100 \mu \mathrm{l}$ da solução substrato $(10 \mathrm{mg}$ OPD $+25 \mathrm{ml}$ Tampão Citrato $+10 \mu l$ peróxido de hidrogênio) em cada poço).

o. Incubar por uma hora em local bem protegido da luz.

p. Proceder leitura em espectrofotômetro com filtro $405 \mathrm{NM}$.

Num Elisa, a decisão se um anofelino é positivo ou não segue critérios semelhantes aos citados para o IRMA. Dados sobre conjugados e variações na técnica podem ser obtidos na seguinte literatura: Burkot et al. (1984), Wirtz et al. (1987), Verhave et al. (1988), Rubio-Palis et al. (1992) e Branquinho et al. (1993). 
Recentemente, descobriu-se que o sangue de bovinos e, às vezes de súnos, ingerido por um anofelino não infectado, pode interferir no teste Elisa para pesquisa de proteína CS de plasmódios humanos, produzindo resultados falsopositivos (Somboon et al., 1993). Por esse e vários outros motivos, aconselha-se lançar mão de ambas as técnicas - a tradicional dissecção de glândulas salivares e imunensaios (IRMA ou ELISA) - quando se planejarem ou levarem a efeito investigações entomológicas em áreas onde não se conhecem bem os vetores.

\section{TESTES PARA MEDIR A SUSCEPTIBILIDADE DE MOSQUITOS A SUBSTÂNCIAS INSETICIDAS}

Existe uma metodologia padronizada pela Organização Mundial da Saúde (WHO, 1970) que é empregada mundialmente para testar a eficácia de substâncias inseticidas. É utilizada para avaliar inseticidas já comercializados quanto ao aparecimento de resistência aos mesmos em populações de mosquitos. Pode ser adaptada para avaliar novos produtos químicos e/ou biológicos com eventuais propriedades inseticidas. Resumiremos a seguir a metodologia na sua forma mais clássica. Os testes devem ser realizados em locais abrigados, livres de inseticidas e de extremos de temperatura, umidade, luz e vento.

\section{Adultos}

Para os testes envolvendo adultos, são produzidos pela OMS "kits" contendo 20 dispositivos conforme os mostrados na Fig. 41. Um primeiro tubo de material plástico transparente marcado com um ponto verde, é forrado com uma folha de papel de filtro $(15 \times 15 \mathrm{~cm})$ limpa ou impregnada apenas com os solventes utilizados para as substâncias a serem testadas, na mesma proporção. Esse conjunto é encaixado sobre um dispositivo intermediário de forma a deixar apenas uma abertura para a inserção de um capturador de sucção. São colocadas dentro desse tubo 15 a 25 fêmeas da população que se deseja testar, de preferência recentemente alimentadas em sangue. É aconselhável, antes de prosseguir, aguardar durante uma hora e então substituir insetos eventualmente danificados. Em outro tubo, similar ao anterior, porém marcado com um ponto vermelho, é colocado o papel de filtro impregnado com o inseticida que se deseja testar. Este último é acoplado do outro lado do dispositivo intermediário, abrindo-se totalmente a guilhotina entre eles.

Soprando-se, os mosquitos são transferidos para o tubo que contém o inseticida ao qual ficarão expostos. A concentração do inseticida e o tempo de exposição variam conforme a substância empregada, devendo ser consultada a bibliografia específica a cada caso (AMCA, 1976; WHO, 1970; WHO, 1976). Para cada concentração ou tempo de exposição o teste deverá ser repetido idealmente em 4 réplicas e contar com um igual número de controles. Após o tempo de exposição, os mosquitos sobreviventes são novamente transferidos da mesma forma, soprando-se no sentido inverso para o tubo inicial. 

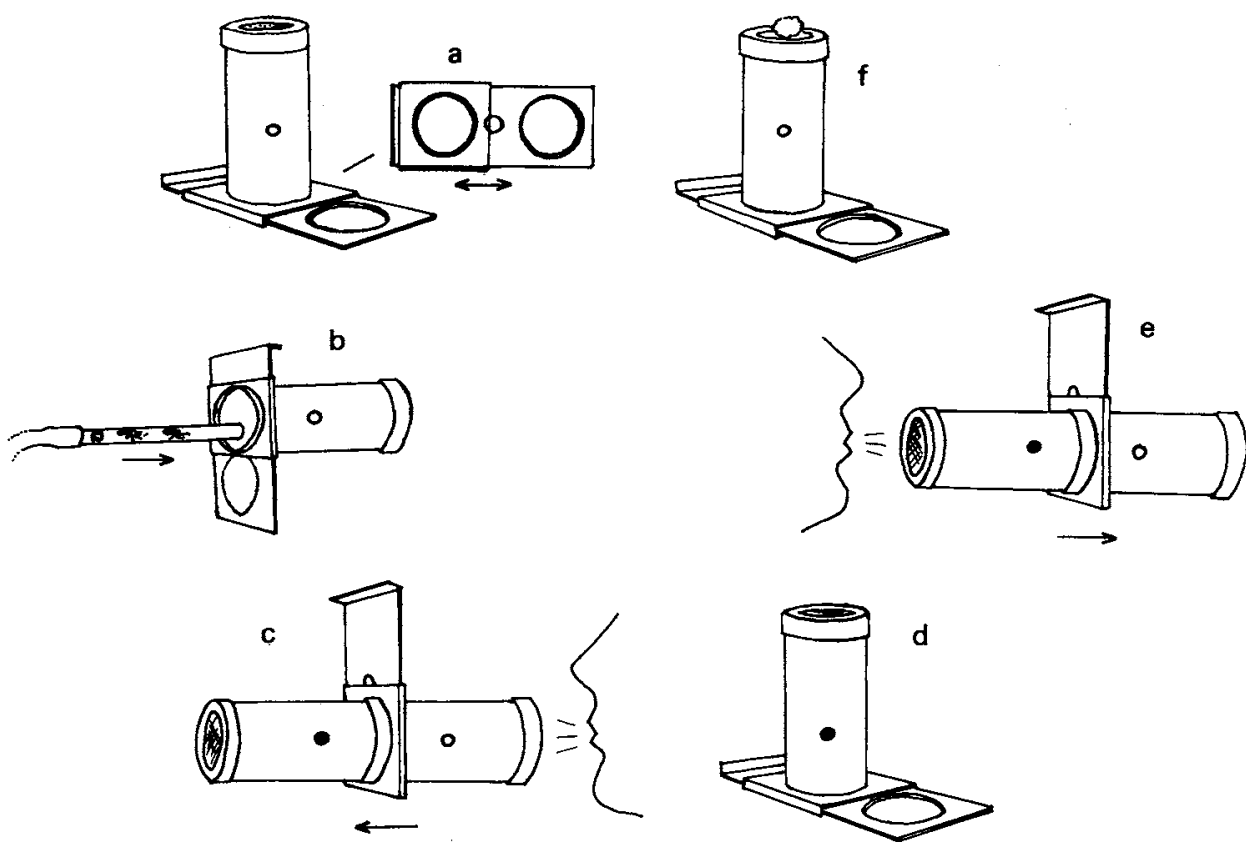

FiG. 41: "Kit" da OMS para testes de susceptibilidade de adultos a inseticidas. a: Peça em forma de guilhotina que pode se fechar totalmente, permitindo acesso a capturador, ou abrir totalmente. b: Transferência de mosquitos para o tubo sem inseticidas. c: Transferência de mosquitos para o tubo com inseticida. d: Aspecto durante o período de exposição. e: Transferência de mosquitos sobreviventes para tubo sem inseticida. $f:$ Mosquitos providos de água durante o período de observação.

A seguir, o tubo com o inseticida é desconectado, mantendo-se os mosquitos por 24 horas em ambiente com temperatura não superior a $30^{\circ} \mathrm{C}$. Colocase sobre o tubo em observação um chumaço de algodão úmido. Decorrido esse prazo, contam-se os mosquitos mortos, considerando-se como tais todos aqueles incapazes de andar. Se a mortalidade nos tubos controles ultrapassar os $20 \%$, todo o teste deve ser repetido; se a mortalidade nos controles estiver entre $5 \%$ e $20 \%$, as percentagens devem ser corrigidas pela fórmula de Abbott:

\% mortalidade no teste $-\%$ mortalidade no controle $\times 100$ 
Com as percentagens de mortalidade obtidas pode-se construir uma linha de regressão em papel "log-probit", encontrando-se por interpolação as concentrações letais $(C L=L C$ : letal concentration) correspondentes a 50\% e 90\% (CL50 e CL90), parâmetros usuais na medida da eficácia de substâncias inseticidas (Fig. 42). Os mesmos cálculos podem ser realizados em computador por diversos programas estatísticos.

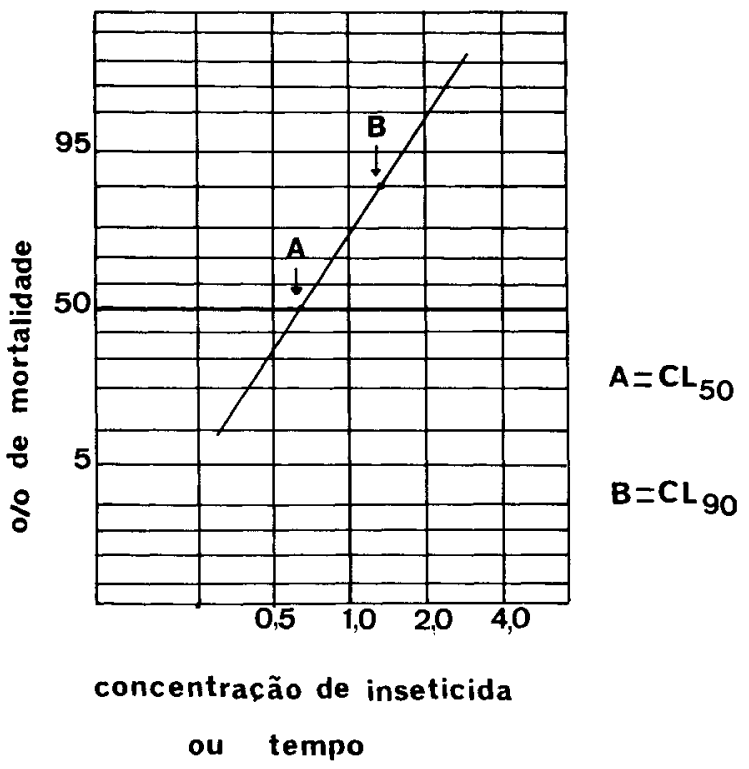

FiG. 42: Determinação das concentrações letais (CL) correspondentes a $50 \%$ e $90 \%$ em linha de regressão traçada em escala "log-probit".

\section{Larvas}

As larvas devem ser de $3^{\circ}$ ou de $4^{\circ}$ estágio, jovens, minimizando-se assim a possibilidade de pupação durante o teste. Também aqui, devem ser feitas preferencialmente 4 réplicas para cada tempo de exposição ou de concentração de substância inseticida utilizada. Para cada réplica são coletadas 20 ou 25 larvas da mesma espécie, por pipetagem direta, em um recipiente preliminar, onde são lavadas com cuidado. A seguir, pode-se removê-las da água por filtração (Fig. 43) e passá-las, invertendo o papel diretamente para o recipiente-teste, evitando-se assim grandes diferenças de tempo entre o preparo da primeira e da última amostra. $O$ recipiente pode ser um copo de material plástico descartável que conterá em geral, $250 \mathrm{ml}$ de uma solução da substância a ser testada. Substâncias não hidro-solúveis podem ser inicialmente dissolvidas em pequenas quanti- 


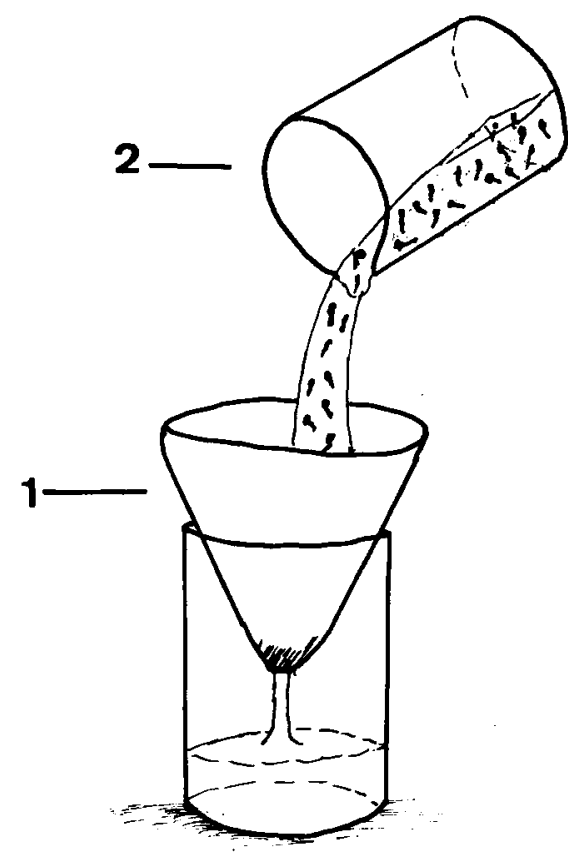

a

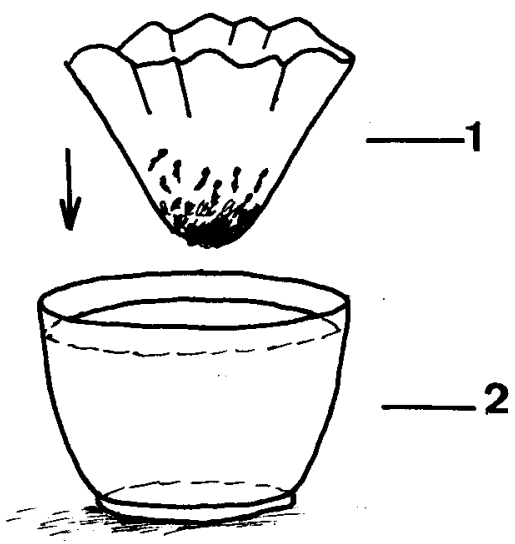

b

Fig. 43: Preparo de teste de substância larvicida. a: Remoção da água de um lote de larvas. b: As larvas aderidas ao papel de filtro (l) são colocadas em contato como o líquido a testar (2).

dades de etanol ou outros solventes para posterior dissolução em água. Deve-se verificar, entretanto previamente, a inocuidade do solvente na concentração empregada, devendo o mesmo estar presente também nas réplicas do controle. Substâncias que formem películas sobre a água não devem ser testadas dessa maneira, pois podem afetar mecanicamente a respiração larvária, e dessa forma invalidar os resultados. Como solvente pode ser utilizada água destilada ou desclorada. Durante o experimento, a temperatura da água deve manter-se entre 20 e $30^{\circ} \mathrm{C}$, preferencialmente próximo aos $25^{\circ} \mathrm{C}$ (Fig. 44). Após 24 horas são contadas as larvas mortas, sendo consideradas como tais todas aquelas incapazes de alcançar a superfície. As larvas que puparam devem ser excluídas da computação dos resultados e se isso ocorreu com mais do que $10 \%$, o teste terá que ser repetido.

O mesmo acontecerá se a mortalidade no controle ultrapassar os $20 \%$. O tratamento dos resultados para obtenção das CL50 e CL90 será similar àquele utilizado para os adultos. 


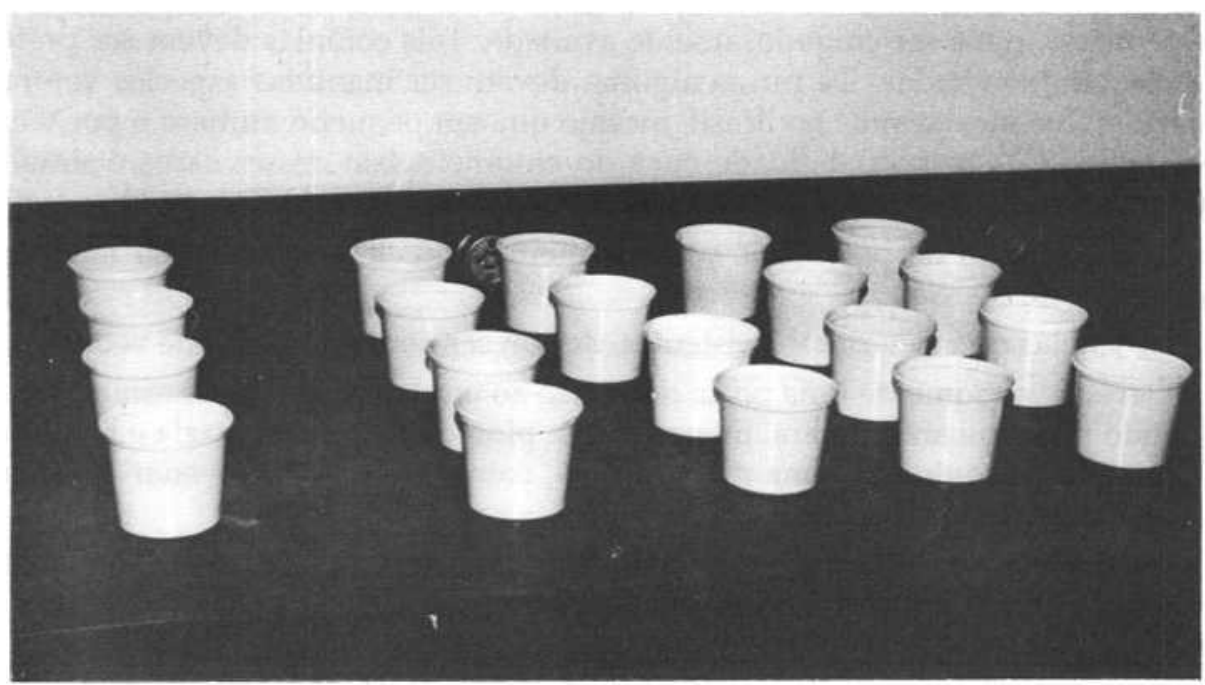

FIG. 44: Teste de susceptibilidade larvária à inseticida. Há quatro réplicas de cada uma das concentrações e no controle.

\section{CRIAÇÃO DE CULICÍDEOS}

O estabelecimento de colônias de culicídeos em laboratório é feita com. muitas finalidades, tais como estudos de biologia (comportamento, fisiologia, genética, citologia etc.), infectividade com diversos patógenos e susceptibilidade a possíveis agentes de controle: químicos, físicos ou biológicos. Em AMCA (1970), encontram-se descritos e referidos processos diferenciados para a criação de 95 espécies de mosquitos, pertencentes a 18 gêneros.

Descreveremos, a seguir, apenas as normas gerais para a manutenção de colônias de mosquitos estenógamos, com referência especial a algumas espécies. Espécies eurígamas, tais como grande parte dos mosquitos do gênero Anopheles neotropicais, possuem em geral exigências complexas, principalmente quanto às condições de acasalamento. Populações limitadas podem ser mantidas com a utilização de técnicas de fecundação artificial (veja item "Colonização: An. deaneorum e outros Nyssorhynchus", p.(194) e Arruda et al., 1982).

\section{Algumas considerações éticas e medidas de segurança}

Embora espécies de mosquitos não vetoras de doenças e aquelas com um potencial muito reduzido de se tornarem vetores possam ser colonizadas de maneira razoavelmente despreocupada, a justificativa para a criação de mosquitos 
transmissores de patógenos em áreas potencialmente endêmicas, especialmente se exóticas, deve ser cuidadosamente avaliada. Tais colônias devem ser preferencialmente evitadas. De forma alguma devem ser mantidas espécies vetoras previamente inexistentes no Brasil, mesmo que em pequeno número e por tempo limitado. A responsabilidade ética do entomologista nesses casos é similar àquela do bacteriologista que cultiva agentes patogênicos (AMCA, 1970).

A criação de potenciais vetores, quando inevitável, demanda medidas adicionais de segurança:

- As janelas no insetário, se existentes, devem ser permanentemente vedadas.

- Deve haver somente uma porta de acesso ao insetário, sendo o mesmo precedido por uma antecâmara, internamente pintada de branco, vazia e bem iluminada e provida de uma porta, a qual, como a outra, deve vedar perfeitamente qualquer abertura.

- Cada pessoa ao deixar o insetário deverá examinar cuidadosamente a antecâmara e eliminar todos os mosquitos eventualmente encontrados.

- Filtros ou telagens especiais devem ser instalados nos condicionadores de ar.

- A água que é drenada pelas pias, ralos etc., deve passar por reservatórios nos quais sejam colocados inseticidas regularmente.

- As larvas devem ser criadas em recipientes cobertos com tela.

- As pupas devem ser removidas diariamente e colocadas dentro de gaiolas para a emergência.

- Os animais para a alimentação sanguínea das fêmeas devem ser colocados sobre as gaiolas teladas e não dentro delas.

- A manga que dá acesso à gaiola de adultos deve ser provida de elástico, de forma a aderir ao braço quando seja necessário manipular utensílios dentro das gaiolas.

- Deve-se treinar o pessoal técnico no sentido de capturar imediatamente qualquer mosquito solto no insetário.

- Espalhar, num raio de $1000 \mathrm{~m}$ em torno do insetário, armadilhas de oviposição adequadas à espécie em questão, controlando-as semanalmente.

\section{$O$ insetário - normas gerais}

É essencial que seja estabelecido em uma sala na qual haja possibilidade de um bom isolamento térmico e de umidade. Uma ante-sala, que poderá servir para o armazenamento de materiais utilizados no próprio insetário, é útil como zona-tampão para a manutenção das condições climáticas dentro do insetário. $O$ ideal é que este não possua janelas, fazendo-se a ventilação por condicionadores de ar, mas se janelas estiverem presentes, devem ser pequenas e sempre teladas e bem vedadas. Toda a superfície interna do insetário deve possuir revestimento claro e lavável, como azulejos ou pintura com tinta a óleo branca e piso de cerâmica clara ou de materiais sintéticos. As portas devem ser claras e têm que possuir ajuste perfeito, sem frestas. Deve haver um mínimo de duas pias, uma delas com torneira ligada a um reservatório de água desprovida de cloro. 


\section{CONTROLE DE TEMPERATURA E UMIDADE}

São fatores essenciais para uma colônia bem-sucedida, que possa apresentar um rendimento uniforme. Deve existir permanentemente dentro do insetário um termômetro para medidas máximas e mínimas diárias e um higrômetro. Existem, também, sistemas de climatização industriais que podem ser instalados, mantendo a temperatura e a umidade desejadas. Para a maioria dos mosquitos neotropicais esses valores se situam entre 26 a $28^{\circ} \mathrm{C}$ e 70 a $80 \%$ de umidade relativa do ar. Na maioria das regiões do Brasil, onde os extremos de temperatura são raros, podem-se obter resultados bastante satisfatórios com a utilização de aquecedores elétricos, aos quais termostatos podem ser acoplados. A umidade pode ser aumentada com o uso de vaporizadores. Em insetários bem isolados, esses últimos podem tornar-se supérfluos devido à existência das numerosas superfícies aquáticas formadas pelos recipientes com larvas, que por vezes fornecem a umidade desejada. Se necessário, pode-se estender camadas de algodão ou gaze úmidas sobre as gaiolas contendo insetos adultos, para aumentar a umidade, tendo o cuidado de renovar essa cobertura com freqüência.

\section{LUMINOSIDADE}

A intensidade luminosa e a duração dos períodos de luminosidade afetam o desenvolvimento dos mosquitos. Períodos de 14 horas de luz e 10 horas de escuridão parecem ser os mais adequados a um grande número de espécies (AMCA, 1970). O controle dos fotoperíodos pode ser conseguido com a instalação de um aparelho do tipo timer na rede elétrica.

\section{Manutenção de adultos}

Os insetos adultos devem ser transferidos para gaiolas apropriadas, das quais existem vários tipos, tamanhos e materiais (madeira, metal, Eucatex, papelão grosso etc.). Gaiolas cúbicas de acrílico transparente $(40 \times 40 \times 40 \mathrm{~cm})$, com cantos arredondados, possuindo 3 faces teladas e a face superior em forma de tampa removível (Fig. 45) mostram-se muito satisfatórias quanto à visibilidade, facilidade de limpeza e dificuldade de instalação de fungos e aranhas. As mangas, de tecido de náilon, são igualmente removíveis. É possível conseguir o acasalamento de espécies estenógamas em espaços menores, mas para uma criação em massa isso implica em aumento de trabalho e muitas vezes em menor rendimento. Quando o fundo da gaiola é forrado por uma folha de papel de filtro a remoção dos insetos mortos é grandemente facilitada. Dentro de cada gaiola é colocado um recipiente para a alimentação açucarada, contendo uma solução de $10 \%$ de mel em água destilada, em contato com tiras de papel de filtro que devem permanecer sempre úmidas (Fig. 46). Em lugar de mel têm sido usadas também glicose, sacarose, frutose e outros carboidratos, passas, bananas, maçãs e mesmo açúcar sólido (Eliason, 1963). Essas fontes alimentares devem ser mantidas permanentemente dentro das gaiolas e devem ser diariamente renovadas.

A alimentação sanguínea deve ser administrada de acordo com as preferências alimentares e o horário de alimentação natural dos mosquitos emprega- 


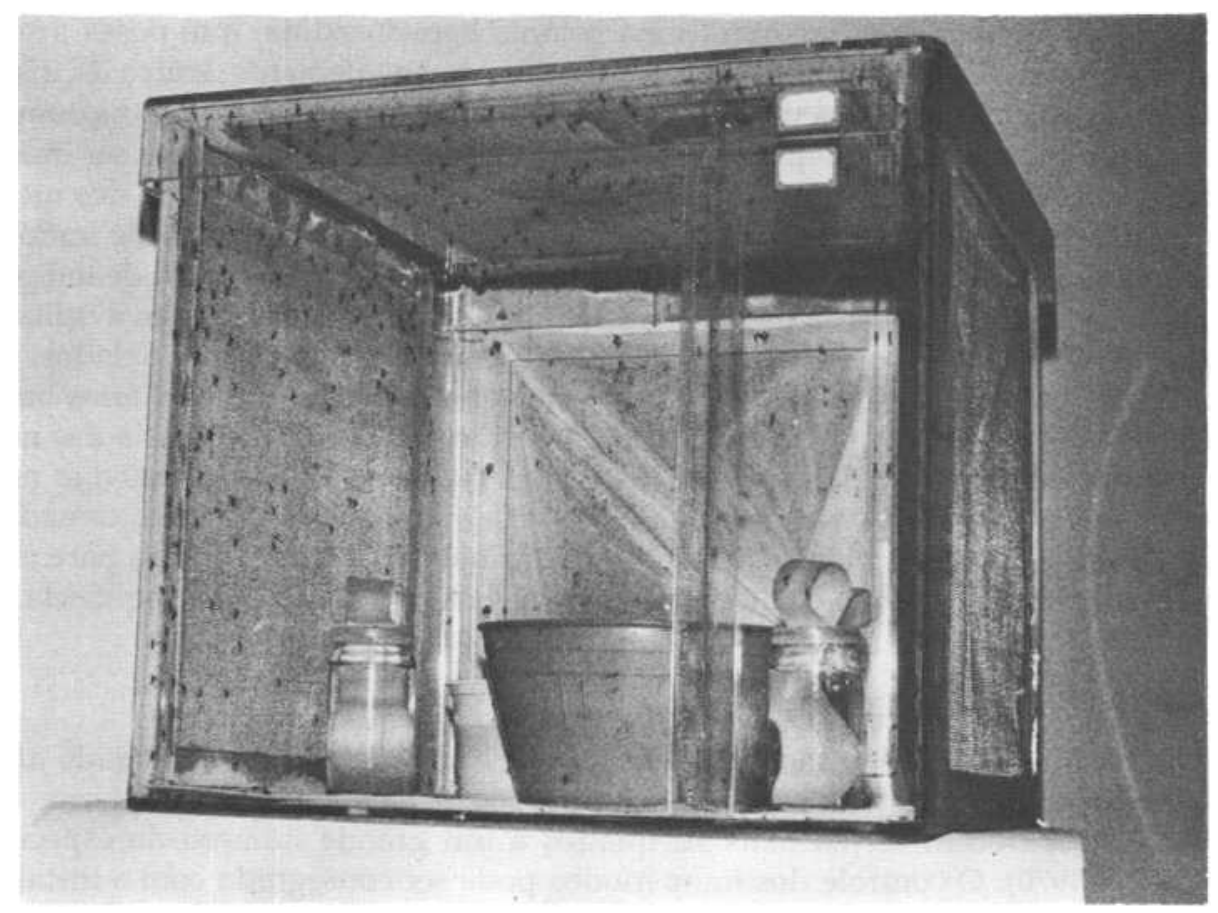

FIG. 45: Gaiola para manutenção de adultos em colônia.

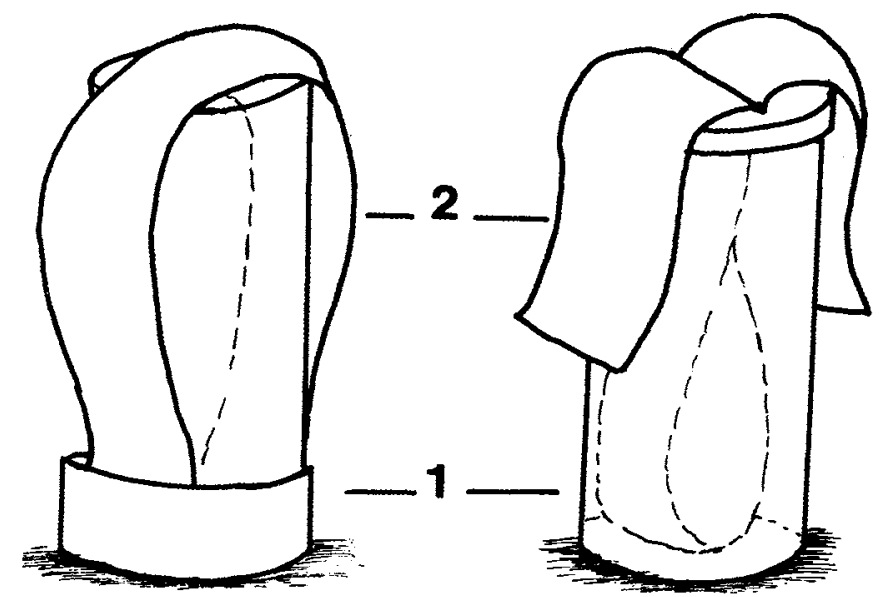

FiG. 46: Recipientes contendo solução de carboidratos para a alimentação de adultos. 1: vidro; 2: papel de filtro. 
dos. Podem-se usar animais imobilizados ou anestesiados, tais como camundongos, ratos, cobaias, pintos, codornas etc. Em algumas situações, a alimentação em sangue humano pode ser necessária - nesse caso, o pesquisador deve certificar-se da ausência de risco de transmissão de qualquer agente patogênico por parte das fêmeas que o picarem, bem como da ausência de reações alérgicas de sua parte. A alimentação sanguínea artificial de mosquitos através de membrana em sangue citratado é possível em muitos casos (Rutledge et al., 1964).

\section{Manutenção dos ovos}

Os mosquitos depositam seus ovos em superfícies líquidas ou posteriormente inundáveis. Para se obter ovos em laboratório é necessário oferecer um meio que substitua adequadamente os criadouros da espécie em questão.

\section{MOSQUITOS QUE DESOVAM NA ÁGUA}

Recipientes de vidro, material plástico, cerâmica ou esmaltados, contendo água, devem ser colocados dentro das gaiolas contendo as fêmeas grávidas. É aconselhável, para obter um bom rendimento e facilitar o manejo, que a superfície líquida tenha no mínimo $30 \mathrm{~cm}^{2}$ e a profundidade não seja inferior a $2 \mathrm{~cm}$. As características químicas da água devem ser compatíveis com a oviposição da espécie (por exemplo, há espécies compatíveis e incompatíveis com a presença de salinidade - mesmo baixa - na água). Recipientes escuros são mais atraentes para muitos mosquitos, assim como a água na qual estiveram as formas imaturas da sua espécie; a adição de vários tipos de matéria orgânica pode ainda propiciar a oviposição (Fay \& Fay, 1965; Ikeshoji \& Mulla, 1970; Consoli \& Teixeira, 1988). A oviposição pode ser também induzida pelo traumatismo, isto é, fêmeas cujo período de gravidez tenha terminado (geralmente 3 dias), ovipõem, prontamente, se as anestesiamos ligeiramente com acetato de etila, arrancamolhes uma das asas e as colocamos sobre a superfície da água (Lanzaro et al., 1988). Quando mosquitos que habitualmente desovam na água passam a fazê-lo em superfícies úmidas, tais como o papel de filtro que contém o alimen:o açucarado, algum fator muito desfavorável deve estar presente na água oferecida para a oviposição. Os ovos podem ser facilmente transferidos para outros recipientes com auxílio de pedaços de papel de filtro.

\section{MOSQUITOS QUE DESOVAM EM SUPERFICIES SÓLIDAS}

A forma mais comum de se obter ovos dessas espécies é oferecer-lhes recipientes com 10 a $15 \mathrm{~cm}$ de altura, revestidos internamente com uma superfície rugosa, como papel de filtro ou papel corrugado e em cujo fundo haja cerca de 3 $\mathrm{cm}$ de água, para se manter o papel úmido. Em lugar destes, outros materiais rugosos e absorventes podem cer utilizados, tais como esponjas, materiais plásticos porosos, cerâmica ou algodão. Freqüentemente tais ovos precisam passar por um período de "condicionamento" após a postura, isto é, devem permanecer 
nos seus substratos úmidos por um ou mais dias antes de serem submetidos à secagem. Após a secagem, esses ovos podem ser armazenados por períodos variáveis.

\section{Eclosão larvária}

As larvas de espécies que ovipõem diretamente na água eclodem, em geral, dentro de 2 ou 3 dias. As larvas de ovos dessecados, por vezes necessitam de água com baixo teor de oxigênio dissolvido para eclodir (Burgess, 1959).

\section{Manutenção das larvas}

As larvas recém-eclodidas devem ser colocadas em recipientes apropriados para o seu desenvolvimento. Tais recipientes podem ser de material plástico, vidro, esmaltado ou aço inoxidável, devem possuir uma ampla área de superfície, mas que não sejam demasiadamente fundos. Bandejas similares às utilizadas em laboratórios fotográficos têm sido utilizadas com sucesso para numerosas espécies. Bandejas brancas ou de coloração clara facilitam o manejo.

Inúmeros meios nutritivos já foram descritos para diferentes espécies de mosquitos. Asahina (1964) faz uma revisão de muitos deles. Espécies diferentes podem adaptar-se melhor a formulações específicas. Temos obtido bons resultados na criação de várias espécies, utilizando ração para camundongos ou gatos, em que se pode agregar um pouco de esterco bovino, ambos finamente peneirados e esterilizados. Larvas que se alimentam predominantemente na superfície da água, como a maioria dos Anophelinae, devem receber alimento seco, pulverizado sobre a superfície. Para as espécies que preferem alimentar-se no fundo, como muitos Culicinae, o alimento deve ser previamente molhado para ir ao fundo. Embora as larvas sejam capazes de nutrir-se raspando superfícies, a maioria das partículas deve ser suficientemente pequena para serem diretamente ingeridas. Desta forma não contribuirão para a poluição da água. A esterilização prévia do alimento é aconselhável para evitar a introdução de microorganismos patogênicos às larvas, particularmente fungos e bactérias do gênero Bacillus. Existem vários sistemas descritos para distribuir as quantidades de alimento ao longo do desenvolvimento larvário (Morland et al., 1963; Gerberg et al., 1968). Costumeiramente, são consumidos entre 3 a $6 \mathrm{mg}$ de alimento por larva durante todo o seu desenvolvimento. Para minimizar os problemas causados pela poluição da água ao longo do desenvolvimento, pode-se renová-la continuamente, por um processo de gotejamento e drenagem (Fig. 47) ou através de lavagens periódicas (em geral a cada 3 dias). O risco de formação de películas na superfície pode ser adicionalmente prevenido, colocando-se uma bomba de ar, (similar àquelas utilizadas em aquários) dentro do recipiente de criação das larvas. Deve-se no entanto estar atento para não agitar a superfície da água de tal forma que as larvas encontrem dificuldade em permanecer nela. Pode-se ainda remover periodicamente a película que se forma na superfície, aderindo a mesma uma folha de papel absorvente por alguns instantes. 


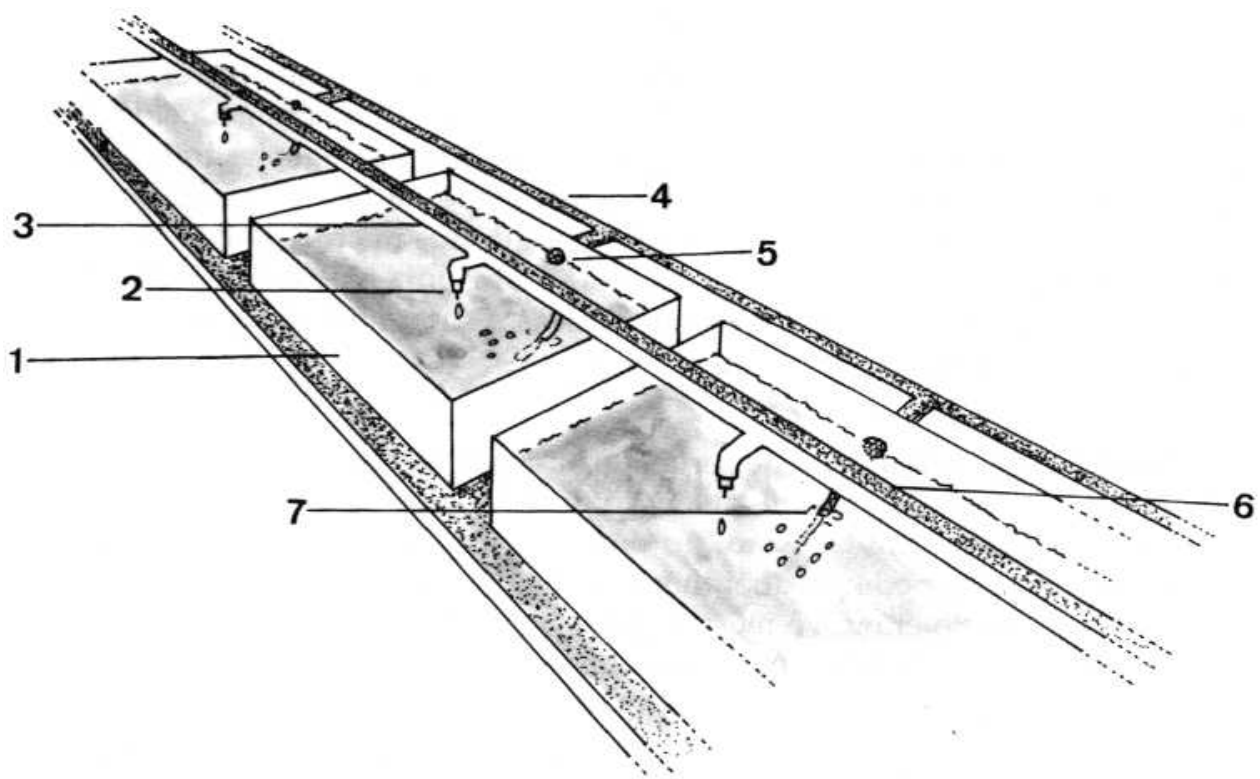

Fic. 47: Sistema para criação de larvas com renovação de água e aeração contínuas. 1: Recipiente que contem as larvas; 2: gotejador de água; 3: cano condutor de água; 4: cano para a remoção de excesso de água; 5: abertura telada para drenagem de água; 6: cano de aeração, ligado a um compressor; 7: tubo de aeração.

\section{Manutenção das pupas}

As pupas devem ser retiradas diariamente dos recipientes, manualmente com pipetas ou pequenas peneiras ou, ainda, mecanicamente com auxílio de uma bomba de vácuo cuja pressão esteja suficientemente baixa para não prejudicar os insetos colhidos. Nas criações em massa, a avaliação diária do número de pupas pode ser feita por um dispositivo semelhante ao descrito na Fig. 36, para a avaliação do número de larvas. A verificação diária do número de pupas é importante para a percepção de quaisquer flutuações no rendimento da colônia. Vários autores descreveram dispositivos mecânicos para separar as pupas maiores, que originarão fêmeas, das menores, que originarão os machos (Fay e Morland, 1959; McCray, 1961). Essas diferenças de tamanho não são uniformemente conspícuas em todas as espécies de mosquitos. 


\section{Manejo de colônias acidentalmente contaminadas por microorganismos e prevenção}

A contaminação acidental de colônias de mosquitos pode ocorrer através da água utilizada, alimento não esterilizado e utensílios contaminados. Formigas e baratas também podem veicular mecanicamente esses agentes infecciosos. A mortalidade exagerada de insetos, principalmente na fase larvária, é o seu principal sintoma. Para a identificação específica desses microorganismos geralmente é necessário um especialista, embora um guia publicado pela OMS (WHO, 1982) forneça algumas diretrizes básicas. Como medidas práticas para eliminar a contaminação sugerimos:

1. Verificar a possibilidade de ser a água a fonte de contaminação. Em caso positivo, mudar a fonte de obtenção de água, desinfetar eventuais reservatórios e/ou filtrá-la. A adição de algumas gotas de tintura de iodo à água utilizada, pode produzir bons resultados, desde que seja previamente ensaiada a tolerância à mesma, pelas larvas da criação. Ae. fluviatilis suporta bem 6 gotas/l de uma tintura de iodo a $6 \%$.

2. Separar algumas gaiolas para adultos, lavá-las muito bem e repovoá-las apenas com novas pupas. Todos os utensílios usados nessas gaiolas devem ser esterilizados ou lavados em solução sulfocrômica, por pelo menos 24 horas.

3. Eliminar as larvas das bandejas contaminadas e esterilizá-las ou lavá-las em solução sulfocrômica.

4. Utilizar uma pipeta estéril para retirar as pupas de cada bandeja, eliminando todas as larvas tão logo apareçam sinais de contaminação.

5. Prevenir novas contaminações desinfetando ou esterilizando periodicamente todo o material empregado.

\section{Colonização de algumas espécies de mosquitos}

\section{Culex quinquefasciatus Say, 1823}

Os ovos são depositados durante a noite diretamente na água formando "jangadas". Recipientes escuros são mais atraentes para as fêmeas que ovipõem do que recipientes claros (Jobling, 1935), assim como a água na qual estiveram larvas, pupas ou ovos (Hudson, 1956; Consoli \& Espinola, 1973; Bruno \& Laurence, 1979). As desovas devem ser transferidas para os recipientes onde serão criadas as larvas, devendo ser usada água sem cloro. A eclosão ocorre após aproximadamente 30 horas à temperatura de 26 a $27^{\circ} \mathrm{C}$. As larvas podem ser alimentadas com a ração anteriormente descrita. Seu manejo não é difícil, mas deve-se estar atento à superpopulação e ao excesso de poluição, ambas prejudiciais ao desenvolvimento. As pupas devem ser retiradas diariamente e colocadas nas 
gaiolas onde eclodirão os adultos. A alimentação açucarada pode seguir os padrões anteriormente descritos. Para a alimentação sanguínea sugere-se a colocação durante a noite de uma gaiola de arame, do tipo utilizado para transporte de pequenos pássaros, contendo uma ou duas codornas às quais tenha sido parcialmente cortada a plumagem da cabeça e dorso. Não há necessidade de anestesiá-las ou contê-las de qualquer outra forma. Pintos ou pombos podem substituir as codornas, embora isto seja geralmente mais trabalhoso. É desnecessário oferecer hospedeiros durante o dia, pois a hematofagia noturna é marcante nessa espécie, a menos que o ambiente seja escurecido. Alguns autores sugerem, para melhores resultados, a remoção da alimentação açucarada 24 horas antes do oferecimento do repasto sanguíneo (AMCA, 1970).

\section{Aedes fluviatilis Lutz, 1904}

Essa espécie neotropical, doméstica ou semidoméstica em muitas regiões do Brasil, não tem sido implicada na transmissão de doença em condições naturais. Constitui, assim, um excelente modelo experimental, podendo, em muitos casos, ser criada em substituição a Ae. aegypti ou Ae. albopictus, sem os riscos que a colonização destes envolve. Os ovos são depositados diretamente na água de forma isolada, devendo ser utilizada água desclorada. Recipientes escuros ou com reflexo dourado e água que conteve larvas ou pupas são especialmente atraentes para as fêmeas. Os ovos são transferidos com papel de filtro preferencialmente para bandejas claras de material plástico, contendo água desclorada onde serão criadas as larvas. A alimentação larvária pode seguir o padrão geral descrito, devendo-se evitar cuidadosamente a formação de película e o excesso de poluição, trocando e aerando a água com freqüência. As pupas recolhidas diariamente são colocadas dentro das gaiolas para adultos, onde a maioria eclodirá 2 dias depois. Quanto à alimentação sanguínea, essa espécie é muito voraz e antropofílica, sugando principalmente de dia, mas também à noite.

Pode-se adaptá-la a diversos hospedeiros, tais como camundongos anestesiados colocados sobre a tela da gaiola durante cerca de 2 horas, durante o dia. Fêmeas que já sugaram sangue em dias anteriores muitas vezes voltam a sugar nos dias subseqüentes mesmo sem terem desovado, mas tais repastos adicionais não aumentam $\_$número de ovos produzidos. Assim uma oportunidade semanal de repasto sanguíneo é suficiente para cada gaiola (Consoli \& Williams, 1978; Consoli \& Williams, 1981; Consoli et ál., 1981; Consoli, 1982; Consoli et al., 1983; Consoli \& Teixeira, 1988; Consoli et al., 1988b).

\section{Aedes aegypti Linnaeus, 1762}

A colonização dessa espécie não deveria ser feita no Brasil a não ser com excepcionais justificativas e medidas de segurança. $O$ fato de já existirem populações em nosso meio não justifica o risco de, eventualmente, contribuirmos para o acréscimo e/ou disseminação de linhagens, às quais poderiam contribuir para a sua maior plasticidade populacional. Os ovos são depositados em superfícies inundáveis, por isso devem ser colhidos da maneira anteriormente descrita. O período embrionário completa-se em poucas horas e, assim, após uma per- 
manência por cerca de 24 horas em "condicionamento" nos recipientes onde foram postos, o substrato (em geral, papel de filtro) pode ser removido e secado por 4 dias à temperatura de 26 a $27^{\circ} \mathrm{Ce} 80 \%$ de umidade relativa do ar. Os ovos podem ser posteriormente armazenados por pelo menos um ano. Para promover a eclosão larvária, os ovos devem ser colocados em água desoxigenada à temperatura de $27^{\circ} \mathrm{C}$. A eclosão deve ocorrer entre 5 a 60 minutos. As larvas devem ser criadas em bandejas pouco profundas e com ampla área de superfície, considerando-se em média a população de 1 larva $/ \mathrm{ml}$ como adequada (AMCA, 1970). A mesma associação recomenda a alimentação das larvas com ração para cães (Purina) pulverizada, conforme o seguinte esquema de distribuição:

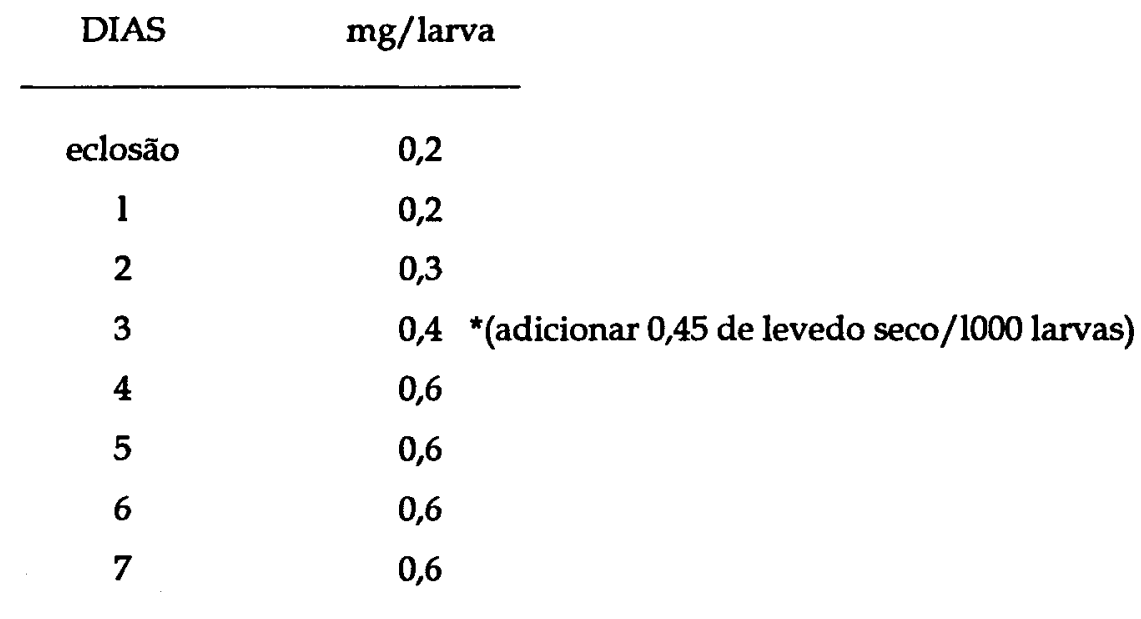

As pupas são separadas das larvas e podem ser divididas conforme o sexo do adulto que originarão (McCray, 1961). Até 2000 pupas podem ser colocadas em gaiolas cúbicas de $30 \mathrm{~cm}$ de lado, sendo adequadas proporções de 3 fêmeas/1 macho. Para alimentação açucarada, pode-se utilizar sacarose a $10 \% \mathrm{em}$ chumaços de algodão trocados diariamente. Cobaias e coelhos anestesiados ou imobilizados com o dorso depilado são as fontes de repasto mais comuns. Em geral, usa-se um repasto por semana (Christophers, 1960).

Aedes albopictus Skuse, 1894

Os mesmos cuidados recomendados para o estabelecimento de colônias de Ae. aegypti devem ser observados na criação dessa espécie exótica. A mesma metodologia descrita para Ae. aegypti pode ser aplicada aqui (Halcrow, 1955; Del Rosário, 1963; AMCA, 1970). Klowden \& Chambers (1992) assinalaram que em comparação com Aedes aegypti essa espécie desenvolve ovos mais facilmente com pequenos repastos sanguíneos, resiste mais tempo à falta de alimento na fase adulta e sua maior eficiência reprodutiva poderia, talvez, ser atribuída ao maior acúmulo de reservas durante a fase larvária. 


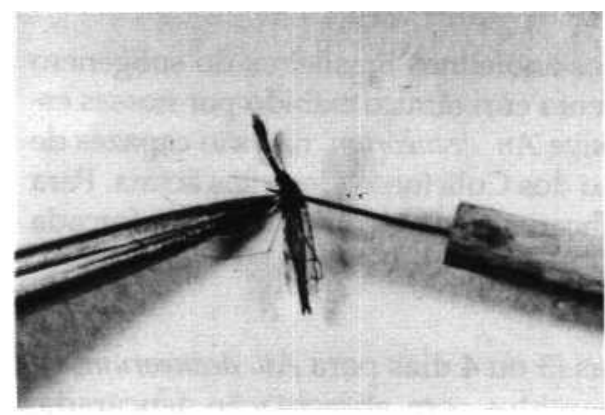

a

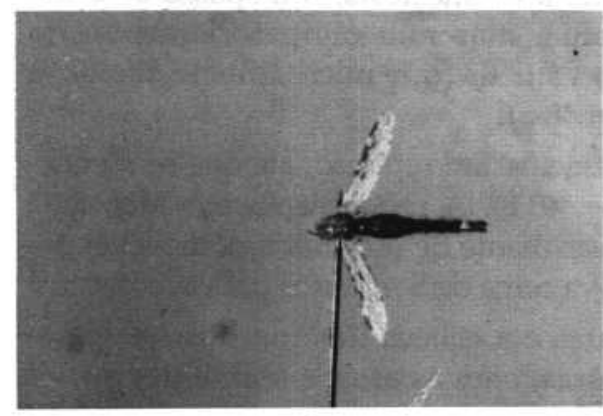

C

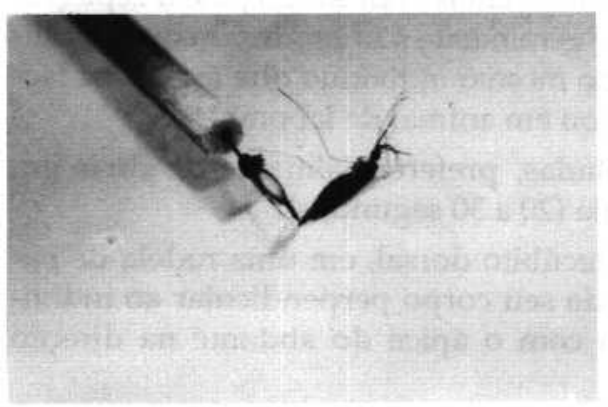

e
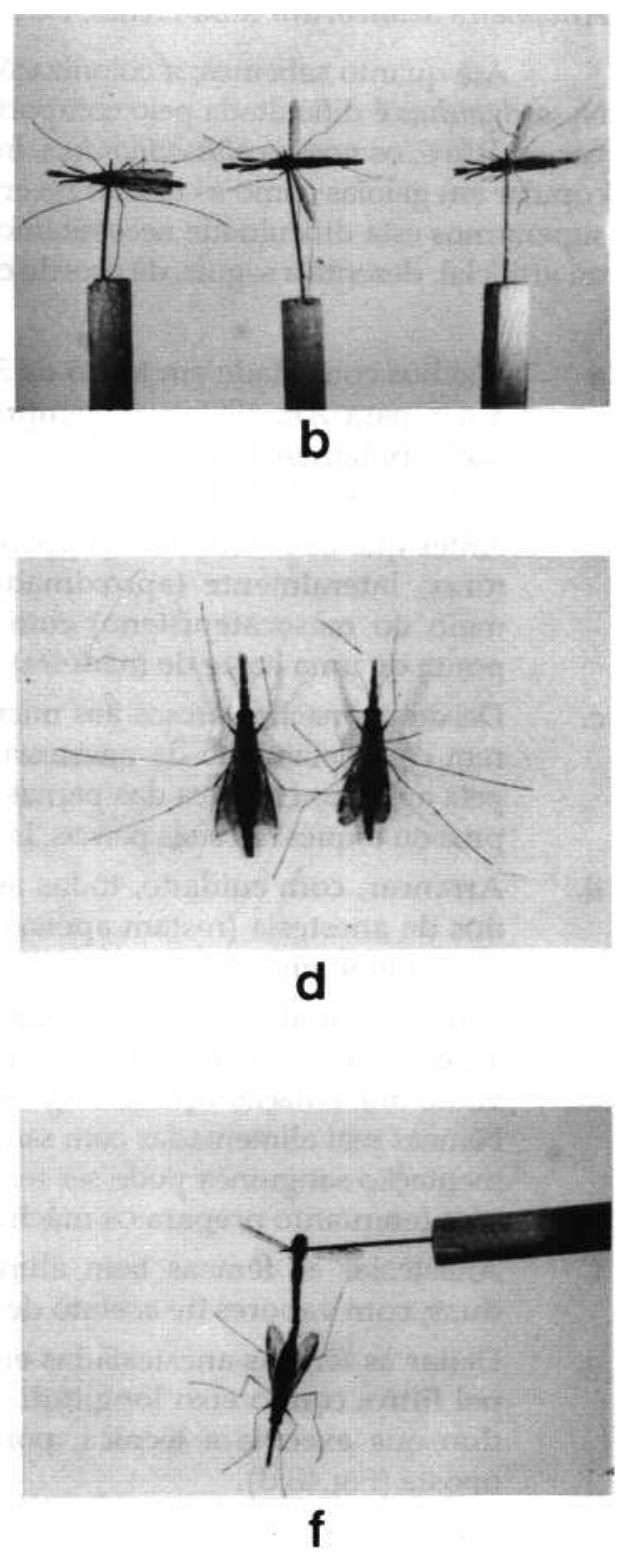

Fig. 48: Cópula forçada em anofelino. a: macho anestesiado, sendo transpassado, no torax, por um microalfinete; b: machos presos a microalfinete, aguardando a recuperação da anestesia; c: macho sem cabeça e pernas, pronto para a cópula; d: fêmeas alimentadas com sangue e anestesiadas, prontas para a cópula; e: fricção, dos últimos esternitos da fêmea, com a genitália externa masculina; f: cópula (macho mantendo a fêmea suspensa). Fotos de José Jurberg. 


\section{Anopheles deaneorum Rosa-Freitas, 1989 e outros Nyssorhynchus}

Até quanto sabemos, a colonização dos anofelinos brasileiros do subgênero Nyssorhynchus é dificultada pelo comportamento eurigâmico exibido por nossas espécies. Isto é, os nossos Nyssorhynchus, inclusive An. deaneorum, não são capazes de copular em gaiolas como as usadas na criação dos Culicíneos, descritas acima. Para superarmos esta dificuldade necessitamos lançar mão da técnica de cópula forçada ou artificial, descrita a seguir, de acordo com Ow Yang et al. (1963).

a. Machos com idade em torno de 3 dias (3 ou 4 dias para An. deaneorum; de 3 a 8 para An. albitarsis), sempre mantidos com alimentação açucarada, são rapidamente anestesiados com vapores de acetato de etila (no máximo por 8 a 10 segundos).

b. Antes que os machos se recuperem da leve anestesia, transpassa-se o seu tórax, lateralmente (aproximadamente, mas não obrigatoriamente, no meio do mesocatepisteno) com um estilete (um microalfinete fixado à ponta de uma haste de madeira) (Fig. 48.a).

c. Deixar os machos presos aos microalfinetes, em repouso, até que se recuperem completamente da anestesia (Fig. 48.b). A recuperação é evidenciada pela agitação enérgica das pernas e asas diante de estímulos, como leves sopros ou toques em suas pernas. Isso leva cerca de 5 minutos para acontecer.

d. Arrancar, com cuidado, todas as patas e a cabeça dos machos recuperados da anestesia (restam apenas o tórax, com as asas, e o abdome presos ao estilete) (Fig. 48.c).

e. Fêmeas com idade em torno de 3 dias (mas podem ser usadas fêmeas com 2 a 6 dias, ou mais), após um período de seis horas de completo jejum (inclusive de alimentação açucarada), são alimentadas com sangue até a repleção. Fêmeas mal alimentadas com sangue geralmente não produzem ovos. A alimentação sanguínea pode ser feita no mesmo indivíduo que executa a técnica (enquanto prepara os machos) ou em animal de laboratório.

f. Anestesiar as fêmeas bem alimentadas, preferencialmente de duas em duas, com vapores de acetato de etila (20 a 30 segundos).

g. Deitar as fêmeas anestesiadas em decúbito dorsal, em uma rodela de papel filtro, com o eixo longitudinal de seu corpo perpendicular ao indivíduo que executa a técnica, porém com o ápice do abdome na direção oposta (Fig.48.d).

h. Friccionar o ápice do abdome (genitália externa) de um macho (preparado no item d) ao ápice do abdome de uma fêmea (preparada no item g). Isto deve ser feito com o eixo longitudinal do corpo do macho em ângulo reto, ou quase reto, com o do corpo da fêmea (obviamente com a face ventral do macho voltada para o indivíduo que executa a técnica) (Fig. 48.e). A fricção deve ser feita suavemente, como se estivéssemos pincelando lentamente os esternitos VII e VIII com a genitália externa do macho, sempre no mesmo sentido, isto é, do esternito VII para o ápice. Essa operação deve ser executada várias vezes, utilizando-se uma lupa (estereoscópio). 
i. Quando o macho está saudável e apto para a cópula, ele abre seus gonocoxitos e gonostilos no instante em que sua genitália toca na da fêmea. Neste momento, a genitália do macho prende a fêmea pelo final do abdome, como um fórceps.

j. Para se certificar de que a cópula está sendo bem sucedida, suspende-se o estilete onde o macho está preso até uma altura de aproximadamente $5 \mathrm{~cm}$ (Fig. 48.f). Se os anofelinos estiverem copulando, o macho será capaz de manter a fêmea suspensa por alguns segundos. As operações (h), (i) e (j) devem ser repetidas na mesma fêmea, por três vezes, utilizando-se o mesmo macho ou não, de modo a assegurar a fecundação.

Cada macho (preparado no item d; Fig. 48.c) pode copular seis vezes, ou mais. De modo geral, empregamos um macho para fecundar duas fêmeas, fazendo-se com que ele copule três vezes com cada uma.

As fêmeas devem ser copuladas já ingurgitadas com sangue. A anestesia pelo acetato de etila tende a inibir a fome.

A cópula artificial se faz mais facilmente em ambiente com temperatura baixa $\left(23\right.$ a $\left.24^{\circ} \mathrm{C}\right)$.

As fêmeas copuladas (item j) devem ser mantidas com alimentação açucarada durante três dias. Então, podemos lhes oferecer local para a desova ou thes forçar a oviposição segundo a técnica de Lanzaro et al. (1988) (ver item "Mosquitos que desovam na água" p.(187)).

As larvas de An. deaneorum e de outros Nyssorhynchus eclodem em dois dias (no máximo três). As larvas eclodidas são transferidas para os recipientes apropriados para o seu desenvolvimento. Em geral, se usam cubas redondas, esmaltadas ou de plástico, de cor branca, com 15 a $20 \mathrm{~cm}$ de diâmetro e 4 a $6 \mathrm{~cm}$ de profundidade. A manutenção das larvas de alguns Nyssorhynchus é beneficiada colocando-se um ramo de planta aquática (Elodea ou Pistia) no recipiente de criação. Essas plantas devem ser, prévia e cuidadosamente, lavadas em água corrente, para evitar a introdução de patógenos ou de predadores na cuba de criação. Recomendamos fazer flutuar na superfície da água pequenos triângulos equiláteros ( $4 \mathrm{~cm}$ lado), feitos com pedaço de canudo de plástico (dos que se usam para tomar refrigerantes), dobrados sobre si mesmos e com as pontas conectadas. Os triângulos e as plantas oferecem maior substrato para que as larvas neles se encostrem e repousem enquanto se alimentam e respiram na superfície.

$\mathrm{O}$ alimento das larvas deve ser pulverizado sobre a superfície da água, em quantidades pequenas, porém crescentes, de acordo com os estágios de desenvolvimento. Usa-se ração para peixe (à base de farinha de peixe) ou diferentes fórmulas (ver item "Manutenção das larvas" p.(188)), dentre as quais destacam-se aquelas à base de farinhas (uma parte de farinha de peixe: uma de farinha de pão: duas de germe de trigo; ou apenas uma parte de farinha de peixe: duas de germe de trigo). Em todos os casos, as rações devem ser bem trituradas, peneiradas e, se possível, autoclavadas.

O excesso de comida na cuba, correspondendo geralmente à sujeira sedimentada, deve ser recolhido, diariamente, com uma pipeta. Dependendo da 
quantidade ou/e qualidade da ração usada, não basta pipetar a sujeira do fundo, necessitando-se trocar totalmente a água da cuba de criação. A água da cuba deve estar sempre translúcida, com aspecto de límpida. Se ela turvar, ou aparecer uma espécie de gosma viscosa no fundo da cuba, é sinal de que chegou o momento de trocar totalmente a água. Os demais cuidados com as larvas e pupas são os sugeridos nas páginas 188 a 190.

$O$ desenvolvimento das larvas de An. aquasalis é beneficiado se as criamos em água dotada de certa salinidade (0,5\% de água do mar).

Os adultos de Nyssorhynchus são alimentados, desde a emergência, com alimentação açucarada (ver item "Manutenção de adultos", p.(185)).

Dados adicionais sobre a colonização de An. deaneorum, An. albiartsis e An. aquasalis podem ser obtidos em Arruda et al., (1982) e Klein et al., (1990). 


\section{REFERÊNCIAS BIBLIOGRÁFICAS}

ABEDI, Z.H. \& BROWN, A.W.A. (1961). Peritrophic membrane as a vehicle for DDT and DDE excretion in Aedes aegypti larvae. Ann. Ent. Soc. Amer., 54: 530-542.

ADAMES, A.J. (1971). A revision of the crabhole mosquitoes of the genus Deinocerites. Contrib. Amer. Ent. Inst. Mosquito Studies XXIV. 7:1-154.

AITKEN, T.H.G. (1960). A survey of trinidadian arthropods for natural virus infection (August, 1953 to December, 1958). Mosquito News, 20: 1-10.

ALDRIDGE, W.N. (1979). Insecticids, past, present and future: practice and the understanding of mechanisms. Ann. occup. Hyg., 22: 407-409.

ALIO, A.Y.; ISAQ A. \& DELFINI, L.F. (1985). Field trial on the impact of Oreochromis opilurus spilurus on malaria transmission in Northern Somalia. WHO/VBC/85.910, $17 \mathrm{pp}$.

AMCA (1952). Ground Equipment and Insecticides for mosquito control. American Mosquito Control Association, INC, $114 \mathrm{pp}$.

AMCA (1968). Ground Equipment and Insecticides for mosquito control. American Mosquito Control Association, INC, $101 \mathrm{pp}$.

ANDREADIS, T.G. (1977). An oviposition attractant of pupal origin in Culex salinarius. Mosquito News, 37: 53-56.

ANDREADIS, T.C. \& HALL, D.W. (1980). Relationship between physiological age and fecundity in Culex salinarius (Diptera: Culicidae). J. Med. Entomol., 17: 485-486.

ANGERILLI, N.P.D. (1980). Influences of extracts of freshwater vegetations on the survival and oviposition by Aedes aegypti (Diptera: Culicidae). Can. Ent., 1l2: 1249-1252.

ARAGÃO, M.B. (1964) Distribuição geográfica e abundância das espécies de Anopheles (Kerteszia) (Diptera, Culicidae). Rev. Bras. Malariol. D. Trop., 16: 73-109.

ARNELL, J.H. (1973) A revision of the genus Haemagogus. Contrib. Amer. Ent. Inst. Mosquito Studies. XXXII, 10: 1-174.

ARNELL, J.H. (1976) A revision of the scapularis group of Aedes (Ochlerotatus). Contrib. Amer. Ent. Inst. Mosquito Studies XXXIII. 13: 1-144.

ARRUDA, M.E.; RIOS, R.I.; ARANTE, P.C.; OLIVEIRA, A.C. \& NASCIMENTO, L.P. (1982). Manutenção em laboratório de Anopheles albitaris e Anopheles aquasalis por copulação induzida. Mem. Inst. Oswaldo Cruz, 77: 89-91.

ARRUDA, M.E.; CARVALHO, M.B.; NUSSENZWEIG, R.S.; MARACIC, M. FERREIRA, A.W. \& COCHRANE, A.H. (1986) Potential vectors of malaria and their different susceptibility to Plasmodium falciparum and Plasmodium vivax in northern Brazil identified by immunoassay. Am. J. Trop. Med. Hyg., 35: 873-881 
ARRUDA, M.E.; NARDIN, E.H.; NUSSENZWEIG, R.S. \& COCHRANE, A.H. (1989) Sero-epidemiological studies of malaria in indian tribes and monkeys of the Amazon basin of Brazil. Am. J. Trop. Med. Hyg., 41: 379-385.

BAILEY, D.L.; JONES, R.G. \& SIMMONDS, P.R. (1983). Effects of indigenous Toxorhynchites rutilus rutilus on Aedes aegypti breeding in tire dumps. Mosquito News, 43: 33-37.

BARBER, M.A. \& RICE, J.B. (1936) Methods os dissecting and making permanent preparation of salivary glands and stomachs of Anopheles . Amer.J. Hyg. 24: 32-40.

BARBOSA, O.C.; TEODORO, U; LOZOVEI, A.L.; SALVIA FILHO, V.; SPINOSA, R.P.; LIMA, E.M. \& FERREIRA, M.E.M.C. (1993). Notas sobre culicídeos adultos coletados na região Sul do Brasil. Rev. Saúde Públ., S. Paulo 27: 214-216.

BARRETTO, M.P. \& COUTINHO, J.O. (1944) Sobre o gênero Taeniorhynchus Arribalzaga, 1891, com a descrição de três novas espécies do subgênero Taeniorhynchus (Diptera, Culicidae). Arquiv. Hig. Saúde Públ., 9: 53-85.

BATES, M. (1949). The natural history of mosquitoes. The Macmillan Company, NY, 379 pp.

BEADLE, L.C. (1939). Regulation of the haemolymph in the saline water mosquito larva Aedes detritus Edw. J. Exp. Biol., 16: 346-362.

BECNEL, J.J. \& JOHNSON, M.A. (1993) Mosquito host range and specificity of Edhazardia aedis (Microspora: Culicosporidae). J. Amer. Mosq. Control Ass. 9: 269-274.

BECKER, N. \& LUDWIG, M. (1993) Investigation on possible resistance in Aedes vexans field populations after 10 - year applications of Bacillus thuringiensis israelensis . J. Amer. Mosq. Control Ass. 9: 221-224.

BEIER, J.C.; COPELAND, R.S.; ONYANGO, F.K.; ASIAGO, C.M.; RAMADHAN, M.; KOECH, D.K. \& ROBERTS, C.R. (1991) Plasmodium species identified by ELISA for sporozoites removed from dried dissected slides. J. Med. Entomol., 28: 533-536.

BELKIN, J.N. (1977) Quinquefasciatus or fatigans for the tropical (southern) house mosquito (Diptera: Culicidae). Proc. Entomol. Soc. Wash., 79: 45-52.

BELKIN, J.N. ; HEINEMANN, S.J. \& PAGE, W.A. (1970) The Culicidae of Jamaica. Contrib. Amer. Ent. Inst. Mosquito Studies XXI. 6: 1-458.

BENTLEY, M.D. \& DAY, J.F. (1989) Chemical ecology and behavioral aspects of mosquito oviposition. Ann. Rev. Entomol. 34: 401- 421.

BENZON, G.L. \& APPERSON, C.S. (1988) Reexamination of chemically mediated oviposition behaviour in Aedes aegypti(L.)(Diptera: Culicidae). J. Med. Entomol. 25: 158-164.

BERLIN, O.G.W. (1969) A revision of the Neotropical subgenus Howardina of Aedes. Contrib. Amer. Ent. Inst., Mosquito studies. XII. 4: 1-190.

BERLIN, O.G.W. \& BELKIN, J.N. (1980) Subgenera Aedinus, Tinoletes and Anoedioporpa of Culex. Contrib. Amer. Ent. Inst. Mosquito Studies XXXVI. 17: 1-104.

BILLINGSLEY, P.F. \& RUDIN, W. (1992) The role of the mosquito peritrophic membrane in bloodmeal digestion and infectivity of Plasmodium species. J. Parasitology 78: 430-440.

BIRLEY, M.H. \& BOORMAN, J.P.T. (1982). Estimating the survival and biting rates of haematophagous insects, with particular reference to Culicoides obsoletus group (Diptera: Ceratopogonidae) in southern England. J. Anim. Ecol., 5l: 135-148.

BRAM, R.A. (1967) Classification of Culex subgenus Culex in the New World (Diptera, Culicidae). Proc. U.S. Nat. Hist. Mus., 120 (3557): 1-122.

BRANQUINHO, M.S.; TAIPE LAGOS; C.B.; ROCRA, R.M.; NATAL, D.; BARATA, J.M.S.; COCHRANE, A.H.; NARDIN, E.; NUSSENZWEIG, R.S. \& KLOETZEL, J.K. (1993). Anophelines in the state of Acre, Brazil, infected with Plasmodium falciparum, P.vivax, the variant P.vivax VK247 and P.malariae. Trans. R. Soc. Trop. Med. Hyg., 87: 391-394. 
BROWN, A.W.A. (1960). Mechanisms of resistance against insecticides. Ann. Rev. Ent., 5: 301-326.

BROWN, A.W.A. (1986). Insecticide resistance in mosquitoes: a pragmatic review. J. Am. Mosq. Control. Assoc., 2: 123-140.

BROWN, B.J.; PLATZER, E.G. \& HUGHES, D.S. (1977). Field trials with the mermithid nematode Romanomermis culicivorax in California. Mosquito News, 37: 603-608.

BROWNE, S.M. \& BENNETT, G.F. (198I). Response of mosquitoes (Diptera: Culicidae) to visual stimuli. J. Med. Entomol., 18: 505-521.

BRUNO, D.W. \& LAURENCE, B.R. (1979). The influence of the apical droplet of Culex egg rafts on oviposition of Culex pipiens fatigans (Diptera: Culicidae). J. Med. Entomol., l6: 300-305.

BURGESS, L. (1959). Techniques to give better hatches of the eggs of Aedes aegypti (L.) (Diptera: Culicidae). Mosquito News, 19: 256-259.

BURKOT, T.R.; ZAVALA, F.; GWANZ, R.W.; COLLINS, F.H.; NUSSENZWEIG, R.S. \& ROBERTS, D.R. (1984) Identification of malaria-infected mosquitoes by a two-sided enzyme-linked immunosorbent assay. Am. J. Trop. Med. Hyg., 33: 227-231.

BUXTON, P.A. (1928). An aspirator for catching midges. Trans. R. Soc. Trop. Med. Hyg., 22: $179-180$.

CAMPOS, R.E. \& GARCIA, J.J. (1993) A simple apparatus to separate mosquito larvae from field collected samples. J. Am. Mosq. Control Assoc. 9: 100-101.

CASTELBERRY, D.T. \& CECH, J.J. Jr. (1990). Evaluation of selected larvivorous fish species suitable for mosquito control in waste water. Mosq. Cont. Res. Ann. Rep., 1989, 29-31.

CASTRO, MG.; LOURENÇO-DE-OLIVEIRA, R.; NOGUEIRA, R.; SCHATZMAYR, H.G.; DEANE, L.M. \& TRAVASSOS DA ROSA, A.P.A. (1991) Ongoing study on arbovirosis in Rio de Janeiro State. II Simp. Internac. sobre arbovirus dos Trópicos e Febres hemorrágicas, Belém, pg. 4.

CAUSEY, O.R.; DEANE, L.M. \& DEANE, M.P. (1944). An illustrated key to the eggs of thirty species of Brazilian Anophelines, with several new descriptions. Amer. J. Hyg., 39: 1-7.

CAUSEY, O.R.; DEANE, M.P.; COSTA, O.R. \& DEANE, L.M. (1945) Studies on the incidence and transmission of filaria Wuchereria bancrofti in Belém, Brazil. Am. J. Hyg., 41: 143-149.

CAUSEY, O.R.; DEANE, L.M. \& DEANE,M.P. (1946) Ilustrated key by male genitalic characteristics for the identification of thirty four species of Anophelinae, with a note on dissection technique. Am. J. Hyg. Monog. Series, 18: 21-34.

CAUSEY, O.R.; KUMM, H.W. \& LAEMMERT, H.W. (1950) Dispersion of forest mosquitoes in Brazil: Further studies. Amer. J. Trop. Med., 30: 301-312.

CHADEE, D.D.; LAKHAN, A. RAMDATH,W.R. \& PERSAD, R.C. (1993) Oviposition response of Aedes aegypti mosquitoes to different concentrations of hay infusions in Trinidad, West Indies. J. Am. Mosq. Control Assoc. 9: 346-348.

CHAPMAN, H.C. (1965) Observations on the biology and ecology of Orthopodomyia califormica Bohart (Diptera: Culicidae). Mosquito News, 24: 432-439.

CHAPMAN, H.C. (1974). Biological control of mosquito larvae. Ann. Rev. Entomol., 19: 33-59.

CHARLES, J.F. (1987). Ultrastructural midgut events in Culicidae larvae fed with Bacillus sphaericus 2297 spore/crystal complex. Ann. Inst. Pasteur./Microb., l38: 471-484.

CHARLWOOD, J.D. (1980). Observations on the bionomics of Anopheles darlingi Root (Diptera: Culicidae) from Brazil. Bull. Ent. Res., 70: 685-692. 
CHARLWOOD, J.D. \& HAYES, J. (1978). Variações geográficas no ciclo de picadas do Anopheles darlingi Root no Brasil. Acta Amazônica, 8: 601-603.

CHRISTOPHERS, S.R. (1960). Aedes aegypti (L.). The yellow fever mosquito - its life history, bionomics and structure. Cambridge University Press, London, $739 \mathrm{pp}$.

CLARK, G.G.: ROHRER, W.H.; ROBBINS, D.N.; PRETULA, H.L.; HARROFF, R.N. (1982). Lacrosse virus activity in Illinois detected by ovitraps. Mosquito News, 44: 551-557.

CLEMENTS, A.N. (1963). The physiology of mosquitoes. International Series of Monographs on pure and applied biology. The Macmillan Company - NY, 393 pp.

COCHRANE, A.H.; COLLINS, W.E. \& NUSSENZWEIG, R.S. (1984). Monoclonal antibody identifies circumsporozoite protein of Plasmodium malariae and detects a common epitope on Plasmodium brasilianum sporozoites. Infect. Immun., 45: 592-595.

COLLESS, D.H. \& CHELLAPAH, W.T. (1960). Effects of body weight and size of bloodmeal upon egg production in Aedes aegypti (Linnaeus) (Diptera, Culicidae). Am. Trop. Med. Parasit., 54: 475-482.

CONN, J. (1990). A genetic study of the malaria vector Anopheles nuneztovari from Western Venezuela. J. Am. Mosq. Control Ass., 6: 400-405.

CONN, J.; COCKBURN, A.F. \& MITCHELL, S.E. (1993). Population differentiation of the malaria vector Anopheles aquasalis using mitochondrial DNA. J. Heredity, 84: 248-253.

COLLIER, B.W.; SOLBERG,V.B.; BROWN, M.W. \& BOOBAR,L.R. (1992). A fabric body light trap for sampling mosquitoes. J. Am. Mosq. Control Assoc., 8: 413-415.

CONSOLI, R.A.G.B. (1980). Influência da salinidade no desenvolvimento de Aedes fluviatilis (Lutz, 1904) em laboratório (Diptera: Culicidade). Rev. Brasil. Biol., 40: 39-43.

CONSOLI, R.A.G.B. (1982). Longevidade dos adultos de Aedes fluviatilis (Lutz, 1904) quando submetidos a diversas dietas de carboidratos e de sangue (Diptera: Culicidae). Rev. Brasil. Biol., 42: 303-310.

CONSOLI, R.A.G.B. \& ESPÍNOLA, H.N. (1973). Possíveis fatores químicos na água que influenciam as fêmeas de Culex pipiens fatigans para a oviposição. Rev. Pat. Trop., l: 49-54.

CONSOLI, R.A.G.B. \& WILLIAMS, P. (1978). Laboratory observations on the bionomics of Aedes fluviatilis (Lutz) (Diptera: Culicidae). Bull. ent. Res., 68: 123-136.

CCNSOLI, R.A.G.B. \& WILLIAMS, P. (1981). Aspects of the biology of laboratory - reared female Aedes fluviatilis. Mosquito News, 4l: 30-36.

CONSOLI, R.A.G.B.; ANDRADE, A.C.B. \& SILVA, E.C. (1981). Influencia da idade cronológica sobre a produção de ovos e o número de dias que antecedem a postura em fêmeas de Aedes fluviatilis (Lutz, 1904) alimentadas em vários hospedeiros. Rev. Brasil. Biol., 4l: 829-832.

CONSOLI, R.A..B.; WILLIAMS, P.; MORENO, E.C.; SANTOS, B.S. (1983). Features of reproduction in laboratory reared Aedes fluviatilis (Lutz, 1904) (Diptera: Culicidade). Mem. Inst.Oswaldo Cruz, 78: 37-47.

CONSOLI, R.A.G.B.; GUIMARÃES, C.T.; SOUZA, C.P. \& SANTOS, B.S. (1984). Atividade predatória de Helobdella triserialis lineata (Hirudinea: Glossiphonidade) sobre formas imaturas de Aedes fluviatilis e Culex quinquefasciatus (Diptera: Culicidade) em laboratório. Rev. Saúde Públ., S. Paulo, 18: 359-366.

CONSOLI, R.A.G.B. \& TELXEIRA, M.A. (1988). Influence of larval and pupal products on the oviposition behaviour of Aedes fluviatilis (Lutz) (Diptera: Culicidae). Mem. Inst. Oswaldo Cruz, 83: 213-218. 
CONSOLI, R.A.G.B.; MENDES, N.M.; PEREIRA, J.P.; SANTOS, B.S. \& LAMOUNIER, M.A. (1988a). Influência de diversos derivados de vegetais na sobrevida das larvas de Aedes fluviatilis (Lutz) (Diptera: Culicidae) em laboratório. Mem. Inst. Oswaldo Cruz, 83(1): 87-93.

CONSOLI, R.A.G.B.; CASTRO, M.M.T.; SILVEIRA, J.N. \& SANTOS, B.S. (1988b). Influência da coloração do substrato no comportamento de oviposição de Aedes fluviatilis (Lutz) (Diptera: Culicidae). Rev. Bras. Entomol., 32: 375-381.

CONSOLI, R.A.G.B.; MENDES, N.M.; PEREIRA, J.P.; SANTOS, B.S. \& LAMOUNIER, M.A. (1989a). Influence of several plant extracts on the oviposition behaviour of Aedes fluviatilis (Lutz) (Diptera: Culicidae) in the laboratory. Mem. Inst. Oswaldo Cruz, 84: 47-51.

CONSOLI, R.A.G.B.; PEREIRA, M.H.; MELO, A.L. \& PEREIRA, L.H. (1989b). Belostoma micantulum Stal, 1858 (Hemiptera: Belostomatidade) as a predator of larvae and pupae of Aedes fluviatilis. Mem. Inst. Oswaldo Cruz, 84: 577-578.

CONSOLI, R.A.G.B.; GUIMARÃES, C.T.; CARMO, J.A.; SOARES, D.M.; SANTOS, J.S.(1991) Astronotus ocellatus (Cichlidae: Pisces) and Macropodus opercularis (Anabatidae: Pisces) as predators of immature Aedes fluviatilis (Diptera: Culicidae) and Biomphalaria glabrata (Mollusca:Planorbidae) Mem. Inst.Oswaldo Cruz., 86: 419-424.

CORREA, R.R. \& RAMALHO, G.R. (1956) Revisão de Phoniomyia Theobald, 1903 (Diptera, Culicidae, Sabethini). Folia Clin. et Biol., 25: 1-176.

COSTA, G.L.; MORAES, A.M.L.; ZICCARDI,M.C.B. \& OLIVEIRA, P.C. (1991) Hyphomycetes produtores de micotoxinas entomotoxigênicas o73 para vetores. XVI Congr. Brasil. Microbiol. Santos, S. Paulo.

COSTA, G.L.; MORAES, A.M.L.; ZICCARDI, M.C.B. \& OLIVEIRA, P.C. (1991) Isolamento de cepas fúngicas de uso em controle biológico de vetores. XVI Congr. Brasil. Microbiol. Santos, S. Paulo.

COSTA, M.J.; FARIAS, E.C. \& BRAGHIN, P.L. (1987). Controle biológico de larvas e pupas de mosquitos através do peixe-do-paraiso (Macropodus opercularis) II Sobrevivência e reprodução do Macropodus opercularis em águas poluidas e eutrofizadas do reservatório Billings. Rev. DAE, 47: 72-74.

COSTA LIMA, A.M.; GUITTON, N. \& FERREIRA, O. (1962) Comentários relativos às espécies da tribo Toxorhynchitini (Megarhini) com a descrição de uma espécie nova de Lynchiella (Diptera, Culicidae). Mem. Inst. Oswaldo Cruz, 60: 225-252.

CURTIN, T.J. \& JONES, J.C. (1961). The mechanism of ovulation and oviposition in Aedes aegypti. Ann. Ent. Soc. Amer., 54: 298-313.

DARSIE, R.F. \& MITCHELL, C.J. (1985) The mosquitoes of Argentina. Parts I and II. Mosq. System., 17: 153-362.

DASH, A.P. \& RANJIT, M.R. (1992) Comparative efficacy of Aphid extracts and some juvenoids against the development of mosquitoes. J. Am. Mosq. Control Assoc. 8: 247-251.

DAVIS, D.E. (1944) A comparision of mosquitoes captured with an avian bait at different vegetation levels. Rev. Entom., 15: 209-215.

DEANE, L.M. (1951) Observações sobre alguns hábitos dos adultos de Culex fatigans, o principal transmissor da filariose em Belém, Pará. Rev. Ser. Esp. Saúde Públ., 4: 423-464.

DEANE, L.M. (1985). Malária no Brasil. Cadernos de Saúde Públ., Rio de Janeiro, 1:86-94.

DEANE, L.M. (1986) Malaria Vectors in Brazil. Mem. Inst. Oswaldo Cruz, 81, Suppl. II: 5-14.

DEANE, L.M. (1988). Malaria studies and control in Brazil. Am. J. Trop. Med. Hyg., 38: 223-230. 
DEANE, L.M. (1989). A cronologia da descoberta dos transmissores da malária na Amazônia Brasileira. Mem. Inst. Oswaldo Cruz, 84 (Supl. IV): 149-156.

DEANE, M.P. \& CAUSEY, O.R. (1943). Viability of Anopheles gambiae eggs and morphology of unusual types found in Brazil. Am. J. Trop. Med., 23: 95-102.

DEANE, L.M.; CAUSEY, O.R. \& DEANE, M.P. (1947) Chave ilustrada para a identificação de trinta e cinco espécies de anofelinos das regiōes Nordestina e Amazônica do Brasil pelos caracteres da fêmea, com notas sôbre os transmissores da malária (Diptera, Culicidae). Rev. Sero. Esp. Saúde Públ, 1: 309-336.

DEANE, L.M.; CAUSEY, O.R. \& DEANE, M.P. (1948) Notas sobre a distribuição e a biologia dos anofelinos das Regiōes Nordestina e Amazônica do Brasil. Rev. Sero. Esp. Saúde Públ., 1: 827-966.

DEANE, L.M. \& DAMASCENO, R. (1948). Altura do pouso das fêmeas de Anopheles darlingi e Anopheles aquasalis nas paredes internas das casas. Rev. Sero. Esp. Saúde Públ., 2: 501-508.

DEANE, L.M.; DEANE, M.P.; FERREIRA NETO, J.A. \& ALMEIDA, F.B. (1971) On the transmission of simian malaria in Brazil. Rev. Inst. Med. Trop. São Paulo, 13 : 311-319.

DEANE, L.M.; FERREIRA-NETO, F.A.; CERQUEIRA, N.L. \& ALMEIDA, F.B. (1968). Studies on monkey malaria in the vicinity of Manaus, State of Amazonas, Brazil. Rev. Inst. Med. Trop., S. Paulo, 10: 325-341.

DEANE, L.M.; FERREIRA-NETO, J.; DEANE, M.P. \& SILVEIRA, I.P.S. (1970) Anopheles (Kerteszia) cruzii, a natural vector of the monkey malaria parasites, Plasmodium simium and Plasmodium brasilianum. Trans. R. Soc. Trop. Med. Hyg. 64: 647.

DEANE, L.M.; VERNIN, C.S. \& DAMASCENO, R.G. (1949) Avaliação das preferências alimentares das fêmeas de Anopheles darlingi e Anopheles aquasalis em Belém, Pará, por meio de provas de precipitina. Rev. Sero. Esp. Saúde Públ., 2: 793-808.

DEL ROSARIO, A. (1963). Studies on the biology of Philippine mosquitoes. II Observations on the life and behaviour of Aedes albopictus (Scuse) in the laboratory. Philipp. I. Sci., 92: 89-103.

DELGADO, N. \& RUBIO-PALIS, Y. (1992). Morphometric characterization of tha malaria vector Anopheles nuneztovari (Diptera: Culicidae) from Western Venezuela. Mosq. System., 24: 231-241.

DELGADO, N. \& RUBIO-PALIS, Y. (1993). Identification of Anopheles (Nyssorhynchus) (Diptera: Culicidae) occurring in Western Venezuela. Mosq. System., 25.

DETINOVA, T.S. (1962). Age-Grouping methods in Diptera of medical importance. WHO, Monograph series nr. 47, 215 pp.

DIMOND, J.B.; LEA, A.O. \& DELONG, D.M. (1958). Nutritional requirements for reproduction in insects. Proc. Tenth. Int. Congr. Ent. 1956: 135-137.

DOBROTWORSKY, N.V. (1959). Notes on Australian mosquitoes (Diptera: Culicidae). IV Aedes alboanulatus complex in Victoria. Proc. Linn. Soc. N.S.W., 84: 131-145.

DREYER, G. \& MEDEIROS, Z. (1990) Filariose linfática: Ainda um desafio. Ciência Hoje, 12: 6-7.

DREYER, G.; MEDEIROS, Z.; BÉLIZ, F.; VERGETTI, G.; VERGETTI, A.; CAFE,'T. \& FONTES, G. (1991) Autochthonous Wuchereria brancrofti microfilaremia in the city of Maceió, Alagoas - Brazil. Mem. Inst. Oswaldo Cruz, 86: 495-496.

DURET, J.P. (1969) Estudio sobre Culex (Melanoconion) ocellatus y sus especies afines (Diptera; Culicidae). Physis, 29:113-129.

EDMAN, J.D.; STRICKMAN, D.; KITTAYAPONG, P. \& SCOTT, T.W.(1992) Female Aedes aegypti (Diptera: Culicidae) in Thailand rarely feed on sugar. J. Med. Entomol. 29: 1035-1038. 
EDWARDS, F.W. (1936) Mosquitoes of the Ethiopian Region. III - Culicine adults and pupae. London, 499 p.

ELLIOT, R. (1972). The influence of vector behavior on malaria transmission. Am. J. Trop. Med. Hyg., 21: 755-763.

EVANS, D.R. \& MELLON, De F. (1962). Electro physiological studies of a water receptor associated with the taste sensilla of the blowfly. J. Gen. Physiol., 45: 487-500.

FARAN, M.E. (1980) A revision of the Albimanus Section of the subgenus Nyssorhynchus of Anopheles. Contrib. Amer. Ent. Inst. Mosquito Studies XXXIV. 15: 1-215.

FAY, R.W. \& PERRY, A.S. (1965). Laboratory studies of oviposition preferences of Aedes aegypti. Mosquito News, 25: 276-281.

FERREIRA NETO, J.A.; DEANE. L.M. \& CARNEIRO, E.W.B. (1970). Infecção natural de guaribas, Alouatta belzebul belzebul (L., 1766), pelo Plasmodium brasilianum Gonder \& Berenberg-Gossler, 1908, no Estado do Maranhão, Brasil. Rev. Inst. Med. Trop., São Paulo, 12: 169-174.

FLORES-MENDOZA, C. (1994) Um estudo sobre alguns aspectos comportamentais, morfológicos e bioquímicos de Anopheles aquasalis Curry, 1932. Tese, Rio de Janeiro: Inst. Oswaldo Cruz.

FLORES-MENDOZA, C. \& DEANE, L.M. (1993). Where are the restingplaces of Anopheles aquasalis males? Mem. Inst. Oswaldo Cruz, 88: 501-502.

FORATTINI, O.P. (1962). Entomologia Médica. Vol. 1., Faculdade de Higiene e Saúde Pública, S. Paulo, 662 pp.

FORATTINI, O.P. (1965a) Entomologia Médica. Vol. II. Fac. Saúde Pública. Univ. São Paulo. $506 \mathrm{p}$.

FORATTINI, O.P. (1965b) Entomologia Médica. Vol. III. Fac. Saúde Pública. Univ. São Paulo. 416.

FORATTINI, O.P. (1987). Comportamento exófilo de Anopheles darlingi Root em Região Meridional do Brasil. Rev. Saúde Públ., S. Paulo, 21: 291-304.

FORATTINI, O.P. \& GOMES, A.C. (1988) Biting activity of Aedes scapularis and Haemagogus mosquitoes in Southern Brazil (Diptera: Culicidae). Rev. Saúde Públ., S. Paulo, 22: 84-93.

FORATTINI, O.P.; GOMES, A.C.; GALATI, E.A.B.; RABELLO, EX. \& IVERSSON, L.B. (1978 a) Estudos ecológicos sobre mosquitos Culicidae no Sistema da Serra do Mar, Brasil. I. Observações no ambiente extradomiciliar. Reo. Saúde Públ., S. Paulo, 12: 297-325.

FORATTINI, O.P.; GOMES, A.C.; GALATI, E.A.B.; RABELLO, E.X. \& IVERSSON, L.B. (1978 b) Estudos ecológicos sobre mosquitos Culicidae no Sistema da Serra do Mar, Brasil. 2. Observaçōes no ambiente domiciliar. Rev. Saúde Públ., S. Paulo, 12: 476-496.

FORATTINI, O.P.; GOMES, A.C.; KAKITANI, I. \& MARUCC, D. (1991) Observaçõoes sobre domiciliação de mosquitos Culex (Melanoconion), em ambientes com acentuadas modificaçōes antrópicas. Rev. Saúde Públ., S. Paulo, 25: 257-266.

FORATTINI, O.P.; GOMES, A.C.; NATAL, D.; KAKITANI, I. \& MARUCCI, D. (1987) Preferências alimentares de mosquitos Culicidae no Vale do Ribeira, São Paulo, Brasil. Rev. Saúde Públ., S. Paulo, 21: 171-187.

FORATTINI, O.P.; GOMES, A.C.; NATAL, D. \& SANTOS J.L.F. (1986) Observaçōes sobre atividade de mosquitos Culicidae em matas primitivas da planície e perfís epidemiológicos de vários ambientes no Vale do Ribeira, São Paulo, Brasil. Rev. Saúde Públ., S. Paulo, 20: 178-203. 
FORATTINI, O.P. \& SALLUM, M.A.M. (1987) Studies on some species of Culex (Melanoconion), with the description of a new one from Southern Brazil (Diptera: Culicidae). Rev. Saúde Públ., 21: 123-156.

FORATTINI, O.P. \& SALLUM, M.A.M. (1989) Taxonomic stdy and redescription of Culex (Melanoconion) theobald (Lutz, 1904) (Diptera: Culicidae). Mem. Inst. Oswaldo Cruz, 84 (supl. IV): 201-208.

FORATTINI, O.P. \& SALLUM, M.A.M. (1992) Cibarial armature as taxonomic characters for the Spisseps Section of Culex (Melanoconion) (Diptera: Culicidae). Mosq. System., 24: 70-84.

FORATTINI, O.P. \& SALLUM, M.A.M. (1993a) Redescription of Culex (Melanoconion) inadimirabilis Dyar and synonymy of Culex (Melanoconion) mistura Komp and Rozeboom (Diptera: Culicidae). Mosq. System., 25: 77-88.

FORATTINI, O.P. \& SALLUM, M.A.M. (1993b) Taxonomic study of some species of the educator group of Culex (Melanoconion) (Diptera: Culicidae). Mosq. System., 25: 89-109.

FORATTINI, O.P.; KAKITANI, I.; MASSAD, E. \& MARUCCI, D. (1993) Studies on mosquitoes (Diptera: Culicidae) and anthropic environment. 4-Survey of resting adults and synanthropic behaviour in South-Eastern, Brazil. Rev. Saúde Públ., S. Paulo, 27: 398-411.

FRAKER, P.J. \& SPECK, J.C.(1978) Protein and cell membrane iodinations with a sparingly soluble chloroamide,1,3,4,6-tetrachloro3a,6a-diphenylglycoluril. Biochem. Biophys. Res. Commun., 80: 849857.

FREITAS, J.R. \& HAMRUM, C.L. (1950). The contact chemoreceptors of adult yellow fever mosquitoes, Aedes aegypti. J. N. Y. Ent. Soc., 58: 133-142.

FROOTE, R.H. (1954) The larvae and pupae of the mosquitoes belonging to the Culex subgenera Melanoconion and Mochlostyrax. Tech. Bull. U.S. Dept. Agric., n. 1091.

FROST, F.M.; HERMS, W.B. \& HOSKIN, W.M. (1936). The nutritional requirements of the larvae of the mosquito Theobaldia incidens (Thom.). J. Exp. Zool., 73: 461-479.

GABALDON, A.; ULLOA, G.; GODOY, N.; MARQUEZ, E. \& PULIDO, J. (1977a) Aedeomyia squamipennis (Diptera: Culicidae) vector natural de malária aviária en Venezuela. Bol. Dir. Malariol. y San. Amb., 17: 9-13.

GABALDON, A.; ULLOA, G.; PULIDO, J. \& SUTIL, E. (1977b) Especies de la familia Culicidae que presentan ornitofilia en Venezuela. Bol. Dir. Malariol. y San. Amb., 17: 3-8.

GABALDON, A.; ULLOA, G. \& ZERPA, N. (1988) Plasmodium cathemerium, cepa de Icteridae inoculable a palomas, patos y pavos; sus vectores $y$ utilidad en enseñanza $e$ investigación. Bol. Dir. Malariol. y San. Amb., 28: 53-68.

GALINDO, P.; TRAPIDO, H. \& CARPENTER, S.J. (1950). Observations on diurnal forest mosquitos in relation to sylvan yellow fever in Panama. Am. J. Trop. Med., 30: 533-574.

GALINDO, P.; BLANTON, F.S. \& PEYTON, E.L. (1954) A revision of the Uranotaenia of Panama with notes on other American species of the genus (Diptera, Culicidae). Ann. Ent. Soc. Amer., 47: 107-177.

GALUM, R. \& FRAENKEL, G. (1957). Physiological effects of carbohydrates in the nutrition of a mosquito, Aedes aegypti and two flies Sarcophaga bullata and Musca domestica. J. Cell. Comp. Physiol., 50: 1-23.

GALVÃO, A.L. \& LANE, J. (1941) Observaçōes sobre alguns anofelinos de Salobra, Mato Grosso (Diptera, Culicidae). Rev. Bras. Hyg., 11: 10-18.

GALVĀO, A.L.; DAMASCENO,R.G. \& MARQUES, A.P. (1942) Algumas observações sobre a biologia dos anofelinos de importância epidemiológica em Belém do Pará. Arq. Hig. (Rio de Janeiro) 12: 51-111. 
GERBERG, E.J.; GENTRY, J.W. \& DIVEN, L.H. (1968). Mass rearing of Anopheles stephensi Liston. Mosquito News, 28: 342-346.

GJULLIN, C.M.; JOHNSEN, J.O. \& PLAPP, F.W. (1965). The effects of odors released by various waters on the oviposition sites selected by two species of Culex. Mosquito News, 25: 266-271.

GORHAM, J.R.; STOJANOVICH, C.J. \& SCOTT, H.G. (1967) Clave ilustrada para los mosquitos anofelinos de Sudamerica Oriental. U.S. Dep. Health, Educ. \& Welfare. 64 p.

GRIFFITHS, R.B. \& GORDON, R.M. (1952). An apparatus which enables the process of feeding by mosquitoes to be observed in the tissues of a live rodent; together with an account of the ejection of saliva and its significance in malaria. Ann. Trop. Med. Parasit., 46: 311-319.

GUEDES, S.S.; FREITAS, J.R. \& XAVIER, S.B. (1953). Contribuição ao conhecimento da distribuição geográfica dos anofelinos e algumas observaçōes sobre a biologia do Anopheles darlingi. Rev. Bras. Malariol. D. Trop., 5: 157-165.

GUEDES, A.S. \& SOUZA, M.A. (1964) Sôbre Psorophora (Janthinosoma) albigenu Lutz, 1908 e Psorophora (Janthinosoma) albipes (Theobald, 1907) (Diptera, Culicidae). Rev. Bras. Malariol. D. Trop., 16: 471-486.

HALCROW, J.G. (1955). Notes on the laboratory colony of Aedes (Stegomyia) albopictus (Scuse) and its distribution in Mauritius. Proc. Roy. Entomol. Soc. London, 30: 40-42.

HAMON, J.; CHAUVET \& THÉLIN, L. (1961). Observations sur les méthodes d'evaluation de l'âge physiologique des femelles d'Anopheles. Bull. World. Hlth. Org., 24: 437-443.

HARBACH, R.E. (1991) A new subgenus of genus Sabethes (Diptera:Culicidae). Mosq. System., 23: 1-9.

HARBACH, R.E. \& KNIGHT, K.L. (1980) Taxonomists' glossary of mosquito anatomy. Plexus Publ., Marlton, New Jersey, 415 pg.

HARBACH, R.E. \& PEYTON, E.L. (1990) Transfer of the subgenus Davismyia from Wyeomyia to Sabethes and description of the type species, Miamyia petrocchiae (Diptera: Culicidae). Mosq. System., 22: 149-159.

HARBACH, R.E. \& PEYTON, E.L. (1993) Morphology and evolution of the larval maxila and its importance in the classification of the Sabethini (Diptera: Culicidae). Mosq. System., 25: 1-16.

HARBACH, R.E.; ROBERTS, D.R. \& MANGUIN, S. (1993) Variation in the hindtarsal markings of Anopheles darlingi (Diptera: Culicidae) in Belize. Mosq. System., 25: 192-197.

HAYES, J.; CALDERON, G.; FALCON, R. \& ZAMBRANO, V. (1987). Newly incriminated anopheline vectors of human malaria parasites in Junin Department, Peru. J. Am. Mosq. Control Assoc., 3: 418-422.

HERVÉ, J.P.; DÉGALLIER, N.; TRAVASSOS DA ROSA, A.P.A. \& SÁ FILHO, G.C. (1985) A febre amarela silvestre no Brasil e os riscos de propagação urbana. Hiléia Médica, Belém, 7: 31-40.

HERVÉ, J.P. \& TRAVASSOS DA ROSA, A.P.A. (1983) Ecologia da febre amarela no Brasil. Rev. Fund. S.E.S.P., 28: 11-19.

HERVÉ, J.P.; DÉGALLIER, N.; TRAVASSOS DA ROSA, A.P.A.; PINHEIRO, F.P. \& SÁ FILHO, G.C. (1986) Arboviroses - Aspectos ecologicos. In: INSTITUTO EVANDRO CHAGAS - 50 anos de contribuição às ciências biológicas e à medicina tropical. Fund. Serv. Saúde Pública, Belém, vol. 1,529 pg.

HILBURN, L.R.; WILLIS, N.L. \& SEAWRIGHT, J.A. (1983). An analisis of preference in the color of oviposition sites exhibited by female Toxorhynchites r. rutilus in the laboratory. Mosquito News, 43: 302-306. 
HOBBS, J.H. \& MOLNA, P.A. (1983). The influence of the aquatic fern Salvinia auriculata on the breeding of Anopheles albimanus in coastal Guatemala. Mosquito News, 43: 456-457.

HOCH, A.L.; PINHEIRO, F.P.; ROBERTS, D.R. \& GOMES, M.L.C. (1987) El virus Oropouche. Transmission en el laboratório por Culex quinquefasciatus.Bol. Ofic. Sanit. panamer., 103: 106-112.

HOPKINS, G.H.E (1936) Mosquitoes of the Ethiopian Region. I - Larval bionomics of mosquitoes and taxonomy of Culicine laroae. London. $250 \mathrm{p}$.

HUANG, Y. (1972) The subgenus Stegomyia of Aedes in Southeast Asia. I - The scutellaris group of species. Contrib. Amer. Ent. Inst. Contrib. to the Mosquito Fauna of Southeast Asia. XIV. 9: 1-109.

HUDSON, B.N.A. (1956). The behaviour of the tame female mosquito in selecting water for oviposition. Jour. Exp. Biol., 33: 478-492.

IKESHOJI, T. \& MULLA, S.M. (1970). Oviposition attractants for four species of mosquitoes in natural breeding waters. Ann. Entomol. Soc. Am., 63: 1322-1327.

IKESHOJI, T.; SAITO, K. \& YANO, A. (1975). Bacterial production of the ovipositional attractants for mosquitoes on fatty acid substrates. Appl. Entomol. Zool., 10: 239-242.

IKEMOTO, T.; SUMITRO, PANJAITAN, W. \& SHIBUYA, T. (1986). Laboratory and small-scale field tests of larvicides and larvivorous fishes against Anopheles sundaicus larvae at Perupuk Village, North Sumatra, Indonesia. Jpn. J. Samit. Zool., 37: 105-102.

INDRIS, B.E.M. (1960). Die Entwicklung im normalen Ei von Culex pipiens L. (Diptera). Z. Morph. Okol. Tiere, 49: 387-429.

ITOH, T. \& KURIHARA, T. (1992) Efficacy of Permethrin - and Cyphenothrin - impregnated nettings against Culex pipiens pallens . J. Am. Mosq. Control Assoc. 89: 84-85.

JENKINS, D.W. (1964). Pathogens, parasites and predators of medically important arthropods. Bull. Wld. Hlth. Org., 30 (suppl.): 5-150.

JEWELL, D. (1981). A security modification for the "American Model" mosquito light trap. Mosquito News, $4 l$ : 183-184.

JOBLING, B. (1935). The effect of light and darkness on oviposition in mosquitoes. Trans. Roy. Soc. Trop. Med. Hyg., 29: 157-166.

JONES, J.C. (1960). The anatomy and rhythmical activities of the alimentary canal of Anopheles larvae. Ann. Ent. Soc. Amer., 53: 459-474.

JUDD, G.J.R. \& BORDEN, J.H. (1980). Oviposition deterrents for Aedes aegypti in extracts of Lemna minor. J. Entomol. S. Brit. Col., 77: 30-33.

KALPAGE, K.S.P. \& BRUST, R.A. (1973). Oviposition attractants produced by immature Aedes atropalpus. Environ. Entomol., 2: 729-730.

KAY, B.M.; CABRAL,C.P.; ARAUJO,D.B.; RIBEIRO,Z.M.; BRAGA,P.H. \& SLEIGH,A.C. (1992) Evaluation of a funnel trap for collecting copepods and immature mosquitoes from wells. J. Amer. Mosq. Control Ass. 8: 372-375.

KITZMILLER, J.B.; KREUTZER, R.D. \& TALLAFERRO, E. (1973). Chromossomal differences in populations of Anopheles nuneztovari. Bull.W.H.O., 48: 435-455.

KLEIN, T.A. \& LIMA, J.B.P. (1990). Seasonal distribution and biting patterns of Anopheles mosquitoes in Costa Marques, Rondonia, Brazil. J. Am. Mosq. Control Assoc., 6: 700-707.

KLEIN, T.A.; LIMA, J.B.P. TADA, M.S. (1991a). Comparative susceptibility of anopheline mosquitoes to Plasmodium falciparum in Rondônia, Brazil. Am. J. Trop. Med. Hyg., 44: 598-603. 
KLEIN, T.A.; LIMA, J.B.P.; TADA, M.S. \& MILLER, R. (1991b). Com parative susceptibility of anopheline mosquitoes in Rondônia, Brazil, to infection by P. vivax. Am. J. Trop. Med. Hyg., 45: 463-470.

KLEIN, T.A.; LIMA, J.B.P. \& TODA-TANG, A. (1990). Colonization and maintenance of Anopheles deaneorum in Brazil. J. Am. Mosq. Control Assoc., 6: 510-513.

KLOTER, K.O.; BOWMAN, D.P.; CARROLL, M.K. (1983). Evaluation of some ovitrap materials used for Aedes aegypti surveillance. Mosquito News, 43: 438-441.

KLOWDEN, M.J. \& LEA, A.O. (1980). "Physiologically old" mosquitoes are not necessarily old physiologically. Amer. J. Trop. Med. Hyg., 29: 1460-1464.

KLOWDEN, M.J. \& CHAMBERS, G.M. (1992) Reproductive and metabolic differences between Aedes aegypty and Ae. albopictus (Diptera: Culicidae). J. Med. Entomol. 29: 467- 471.

KNAUS, R.M.; FOIL, L.D.; ISSEL, C.J. \& LEPRINCE, D.J. (1993) Insect blood meal studies using radiosodium $24 \mathrm{Na}$ and $22 \mathrm{Na}$. J. Am. Mosq. Control Assoc. 9: 246-268.

KNIGHT, K.L. (1978) Supplement to A catalog of the mosquitoes of the world (Diptera: Culicidae). The Thomas Say Foundation, vol.VI (Suppl.), $107 \mathrm{pg}$.

KNIGHT, K.L. \& STONE, A. (1977) A catalog of the mosquitoes of the world (Diptera: Culicidae). The Thomas Say Foundation, vol. VI, 611 pg.

KREUTZER, R.D.; KITZMILLER, J.B. \& FERREIRA, E. (1972). Inversion polymorphism in the salivary gland chromosomes of Anopheles darlingi. Mosquito News, 32: 555-556.

KREUTZER, R.D.; KITZMILLER, J.B. \& RABBANI, M.G. (1976). Cytogenetically distinguishable sympatric and allopatric populations of the mosquito Anopheles albitarsis. Acta Amazônica, 6: 473-481.

KUMM, H.W. \& CERQUEIRA, N.L. (1951) The role of Aedes leucocelaenus in the epidemiology of jungle yellow fever in Brazil. Bull. Ent. Res., 42: 195-200.

LAEMMERT, H.W.; CASTRO FEREIRA, L. \& TAYLOR, R.M. (1946) An epidemiological study of jungle yellow fever in a endemic area in Brazil. Part II - Investigation of vertebrate hosts and arthropod vectors. Amer. J. Trop. Med., 26: 23- 69.

LANCIANI, C.A. (1993) Photoperiod and longevity in Anopheles crucians. J. Am. Mosq. Control Assoc. 9: 308-312.

LANE, J. (1953) Neotropical Culicidae. Univ. São Paulo. 2 vols. 1112 p.

LANE, J. \& CERQUEIRA, N.L. (1942) Os Sabetíneos da América (Diptera, Culicidae). Arch. Zool., São Paulo. 3: 473-849.

LANE, J. \& WHITMAN, L. (1951) The subgenus Microculex in Brazil (Diptera, Culicidae). Rev. Brasil. Biol., 11: 341-366.

LANZARO, G.C; NARANG, S.K.; MITCHELL, S.E.; KEISER, P.E. \& SEAWRIGHT, J.A. (1988). Hybrid male sterility in crosses between field and laboratory strains of Anopheles quadrimaculatus (Say) (Diptera: Culicidae). J. Med. Entomol., 25: 248-255.

LEA, A.O. \& DE LONG (1958). Studies on the nutrition of Aedes aegypti larvae. Proc. Tenth. Int. Congre. Ent. (1956), 2: 299-302.

LEISER, L.B. \& BEIER, J.C. (1982). A comparison of oviposition traps and New Jersey light traps for Culex population surveillance. Mosquito News, 42: 391-395.

LOGAN, T.M. (1990). Pretreatment of floodwater Aedes habitats (dambos) in Kenya with a sustained - release formulation of methoprene. J. Am. Mosq. Cont. Assoc., 6: 736-738.

LOPES, O.S.; SACCHETTA,L.A.; FRANCY, D. B.; JAKOB, W.L. \& CALISHER, C.H. (1981) Emergency of a new arbovirus disease in Brazil. III. Isolation of Rocio virus from Psorophora ferox (Humboldt, 1819). Amer. J. Epidem., 113: 122-125.

LOUNIBUS, L.P. (1991) A mother superior. Naturals History, (July): 46-48. 
LOURENÇO-DE-OLIVEIRA, R. (1984) Alguns aspectos da ecologia dos mosquitos (Diptera: Culicidae) de uma área de planície (Granjas Calábria), em Jacarepaguá, Rio de Janeiro. I. Freqüência comparativa das espécies em diferentes ambientes e métodos de coleta. Mem. Inst. Oswaldo Cruz, 79: 479-490.

LOURENÇO-DE-OLIVEIRA, R. (1989) Some observations on the mosquitoes of indian settlements in Xingu National Park, Mato Grosso State, Brazil, with emphasis on malaria vectors. Rev. Brasil. Biol., 49: 393-397.

LOURENÇO-DE-OLIVEIRA, R.; SILVA, T.F. \& HEYDEN, R. (1985) Alguns aspectos da ecologia dos mosquitos (Diptera: Culicidae) de uma área de planície (Granjas Calábria), em Jacarepaguá, Rio de Janeiro. II. Freqüência mensal e no ciclo lunar. Mem. Inst. Oswaldo Cruz, 80: 123-133.

LOURENÇO-DE-OLIVEIRA, R. \& SILVA, T.F. (1985) Alguns aspectos da ecologia dos mosquitos (Diptera: Culicidae) de uma área de planície (Granjas Calábria), em Jacarepaguá, Rio de Janeiro. III. Preferência horária das fêmeas para o hematofagismo. Mem. Inst. Oswaldo Cruz, 80: 195-202.

LOURENÇO-DE-OLIVEIRA, R. \& HEYDEN, R. (1986) Alguns aspectos da ecologia dos mosquitos (Diptera: Culicidae) de uma área de planície (Granjas Calábria), em Jacarepaguá, Rio de Janeiro. IV. Preferências alimentares quanto ao hospedeiro e freqüência domiciliar. Mem. Inst. Oswaldo Cruz, 81: 15-27.

LOURENÇO-DE-OLIVEIRA, R.; HEYDEN, R. \& SILVA, T.F. (1986) Alguns aspectos da ecologia dos mosquitos (Diptera: Culicidae) de uma área de planície (Granjas Calábria), em Jacarepaguá, Rio de Janeiro. V. Criadouros. Mem. Inst. Oswaldo Cruz, 81: 265-271.

LOURENÇO-DE-OLIVEIRA, R. \& CASTRO, F.A. (1989) Ornitophilic mosquito species and the domestic fowl malaria vector in Rio de Janeiro, Brazil. Mem. Inst. Oswaldo Cruz, 84 (Suppl.II): 143

LOURENÇO-DE-OLIVEIRA, R.; GUIMARÃES, A.G.; ARLÉ, M. SILVA, T.F.; CASTRO, M.G.; MOTTA, M.A. \& DEANE, L.M. (1989) Anopheline species, some of their habits and relation to malaria in endemic areas of Rondônia state, Amazon region of Brazil. Mem. Inst. Oswaldo Cruz, 84: 501-514.

LOURENÇO-DE-OLIVEIRA, R. \& CASTRO, F.A. (1991) Culex saltanensis Dyar, 1928 - Natural vector of Plasmodium juxtanucleare in Rio de Janeiro, Brazil. Mem. Inst. Oswaldo Cruz, 86: 87-94.

LOURENÇO-DE-OLIVEIRA, R.; SILVA, T.F. \& CASTRO, M.G. (1991) On the immature stages of two mosquitoes (Diptera: Culicidae) originally described from Rio de Janeiro, Brazil. Mem. Inst. Oswaldo Cruz, 86: 209-218.

LUCENA, D.T. (1950) Hábitos domiciliares do Anopheles tarsimaculatus Goeldi, 1905. Rev. Brasil. Mal., 2: 239-260.

MAGNARELLI, L.A. (1980). Bionomics of Psophora ferox (Diptera: Culicidae) seasonal occurence and acquisition of sugars. J. Med. Ent., l7: 328-332.

MARICONI, F.A.M. (1980). Inseticidas e seu emprego no combate às pragas. Vol. 1, 4a. edição, 1980, Editora Nobel, SP, 305 pp.

MARTEN, G.G. (1990) Elimination of Aedes aegypti from tire piles by introducing Macrocyclops albidus (Copepoda: Cyclopidae). J. Am. Mosq. Control Assoc. 6: 689 - 693.

MARTEN, G.G.; CHE, W. \& BORDES, E.S. (1993) Compatibility of cyclopoid copepods with mosquito insecticides. J. Am. Mosq. Control Assoc. 9: 150-154.

MATSUMURA, F. \& BROWN, A.W.A. (1961). Biochemical study of a malathion tolerant strain of Aedes aegypti. Mosquito News, 2l: 192-194. 
Mc CRAY, E. M. Jr. (1961). A mechanical device for the rapid sexing of Aedes aegypti pupae. J. Econ. Entomol., 54: 819.

MEDEIROS, Z.; DREYER, G.; ANDRADE, L.D.; PIRES, M.L.; MENDES, J. \& PIMENTAEL, R. (1992) Wuchereria bancrofti microfilarial density of autochthonous cases and natural Culex infectivity rates in northeast Brazil. J. Trop. Med. Hyg., 95: 214-217.

MILLAR, J.G., CHANEY,J.D. \& MULLA,S.M. (1992) Identification of oviposition attractants for Culex quinquefasciatus from fermented bermuda grass infusions. J. Am. Mosq. Cont. Assoc. 8: 11-17.

MILLER, B.R. \& BALLINGER, M.E. (1988) Aedes albopictus mosquitoes introduced into Brazil: vector competence for yellow fever and dengue viruses. Trans. $R$. Soc. Trop. Med. Hy8., 82 : 476-477.

MILWARD DE ANDRADE, R. (1959a). Cloro dos cloretos e pH em biótopos de Anofelinos pesquisados no Distrito Federal, Brasil I. Anopheles tarsimaculataus e Anopheles argyritarsis (Diptera: Culicidae). Rev. Bras. Mal. D. Trop., 10: 17-30.

MILWARD DE ANDRADE, R. (1959b). Cloro dos cloretos e pH em biotopos de Anofelinos pesquisados no Distrito Federal, Brasil II. Anopheles albitarsis e Anopheles noroestensis (Diptera: Culicidae). Rev. Bras. Mal. D. Trop., 10: 117-125.

MITCHELL, C.J. \& FORATTINI, O.P. (1984). Experimental transmission of Rocio encephalitis virus by Aedes scapularis (Diptera: Culicidae) from the endemic zone in Brazil. J. Med. Entomol., 21: 34-37.

MITCHELL, C.J.; FORATTINI, O.P. \& MILLER, B.R. (1986) Vector competence experiments with Rocio virus and three mosquito species from the epidemic zone in Brazil. Rev. Saúde Puibl., S. Paulo, 20: 171-177.

MITCHELL, C.J. \& MILLER, B.R. (1990) Vertical transmission of dengue viruses by strains of Aedes albopictus recently introduced into Brazil. J. Am. Mosq. Control Assoc., 6: 251-253.

MIURA, T. \& TAKAHASHI, R.M. (1973). Laboratory and field observations on oviposition preferences of Aedes migromaculis (Diptera: Culicidae). Ann. Entomol. Soc. Am., 66: 244-25l.

MORLAND, H. B.; HAYES, R.O. \& SCHOOF, H. (1963). Methods for mass rearing of Aedes aegypti (L.). U.S. Public Rpts, 78: 711-719.

MORRIS, C.D. \& De FOLIART, G.R. (1969). A comparison of mosquito catches with miniature light traps and $\mathrm{CO} 2$ baited traps. Mosquito News, 29: 424-426.

MULHERN, T.D. (1953). Better results with mosquito light traps through standardizing mechanical performance. Mosquito News, 13: 130-133.

NASCI, R.S.; HARE, S.G. \& WILLIS, S. (1989). Interspecific mating between Louisiana strains of Aedes albopictus and Aedes aegypti in the field and laboratory. J. Am. Mosq. Control Assoc., 5: 416-421.

NASCI, R.S.; TANG, K.H.; BECNEL, J.J. \& FUKUDA, T. (1992) Effect of per os Edhazardia aedis (Microsporida: Amblyosporidae) infection on Aedes aegypti mortality and body size. J. Am. Mosq. Control Assoc. 8: 131-136.

NATAL, D. (1981) Importância epidemiológica de Culex do subgênero Melanoconion (Diptera, Culicidae). Tese. Fac. Saúde Públ., Univ. S. Paulo, 89 pg + anexos.

NAYAR, J.K. (1982) Bionomics and phisiology of Culex nigripalpus (Diptera: Culicidae) of Florida: An important vector of diseases. Tech. Bull., n. 827, Florida Agric. Exper. Station, $73 \mathrm{pg}$. 
NAYAR, J.K. (1985) Bionomics and Physiology of Aedes taeniorhynchus and Aedes sollicitans, the salt marsh mosquitoes of Florida. Tech. Bull., n.852, Florida Agric. Exper. Station, $148 \mathrm{pg}$.

NAYAR, J.K. \& SAUERMANN, Jr. D.M. (1973). A comparative study of flight permance and fuel utilization as a function of age in females of Florida mosquitoes. J. Insect. Physiol., 19: 1977-1988.

NAYAR, J.K. \& SAUERMANN, Jr. D.M. (1975). The effects of nutrition on the survival and fecundity in Florida mosquitoes II. Utilization of a blood-meal for survival. $J$. Med. Entomol., 12: 99-103.

NELSON, S.M. \& KEENAN, L.C. (1992) Use of an indigenous fish species, Fundulus zebrinus in a mosquito abatement program: a field comparison with the mosquito fish Gambusia affinis. J. Am. Mosq. Control Assoc. 8: 301-304.

OLIVEIRA-FERREIRA, J.; LOURENÇO-DE-OLIVEIRA, R.; DEANE, L.M. \& DANIEL-RIBEIRO, C.T., 1992. Feeding preference of Anopheles darlingi in malaria endemic areas of Rondônia state - Northwestern Brazil. Mem. Inst. Oswaldo Cruz, 87: 601-602.

OLIVEIRA-FERREIRA, J.; LOURENÇO-DE-OLIVEIRA, R.; TEVA, A.; DEANE, L.M. \& DANIEL-RIBEIRO, C.T. (1990) Natural malaria infections in anophelines in Rondônia State, Brazilian Amazon. Am. J. Trop. Med. Hyg., 43: 6-10.

$\mathrm{O}^{\prime}$ ROURKE, F.J. (1956). Observations on pool and capillary feeding in Aedes aegypti (L.). Nature, Lond., 177: 1087-1088.

OW YANG, C.F.; ST. MARIA, F.L. \& WHARTON, R.H. (1963). Maintenance of a laboratory colony of Anopheles maculatus Theobald by artificial maiting. Mosquito News, 23: 34-35.

OZAKI, L.S.; GWADS, R.W. \& GODSON, G.N. (1984). Simple centrifugation method for rapid separation of sporozoites from mosquitoes. J. Parasit., 70: 831-833.

PETERSEN, J.J. (1978). Observations on the mass production of Romanomermis culicivorax, a nematode parasite of mosquitoes. Mosquito News, 38: 83-86.

PEYTON, E.L.; WILKERSON, R.C. \& HARBACH, R.E. (1992) Comparative analysis of the subgenera Kerteszia and Nyssorhynchus of Anopheles (Diptera: Culicidae). Mosq. System., 24: 51-69.

PEYTON, E.L. (1993) Anopheles (Nyssorhynchus) dunhami, resurrected from synonymy with Anopheles nuneztovari and validated as a senior synonymy of Anopheles trinkae (Diptera: Culicidae). Mosq. System., 25:151-156.

PINHEIRO, F.P.; TRAVASSOS DA ROSA, A.P.A.; TRAVASSOS DA ROSA, J.F.S.; ISHAK, R.; FREITAS, R.B.; GOMES, M.L.C.; LE DUC, J.W. \& OLIVA, O.F.P. (1981) Oropouche virus. I. A review of clinical, epidemiological, and ecological findings. Amer. J. Trop. Med. Hyg., 30: 149-160.

PINTO, C. (1923). Disseminação da malária pela aviação; Biologia do Anopheles gambiae e outros anofelinos do Brasil. Mem. Isnt. Oswaldo Cruz, 34 : 293-430.

PUMPINI, C.B.; KNEPLER, J. \& CRAIG, G.B. (1992) Influence of temperature and larval nutrition on the diapause inducing photoperiod of Aedes albopictus . J. Am. Mosq. Control Assoc. 8: 223-227.

QUIÑONES, M.L. \& SUAREZ, M.F. (1989). Irritability to DDT of natural populations of the primary malaria vectors in Colombia. J. Am. Mosq. Control Assoc., 5: 56-59.

QUIÑONES, R.L. \& SUAREZ, M.F. (1990). Indoor resting heights of some Anophelines in Colombia. J. Am. Mosq. Control Assoc., 6: 602-604.

RACHOU, R.G. (1956) Transmissores da filariose bancroftiana no Brasil. Rev. Bras. Malariol. D. Trop., 8: 267-279. 
RACHOU, R.G. (1958) Anofelinos do Brasil: comportamento das espécies vetoras de malária. Rev. Bras. Malariol. D.Trop., 10: 145-181.

RACHOU, R.G.; FERREIRA NETO, M.O.; MARTINS, C.M. \& FERREIRA NETO, J.A. (1958) Variação mensal da densidade domiciliária do Culex pipiens fatigans em Florianópolis (Santa Catarina). Rev. Brasil. Mal. D. Trop., 10: 51-9.

RACHOU, R.G.; LIMA, M.M.; FERREIRA NETO, J.A. \& MARTINS, C.M. (1957) Avaliação da domesticidade do Culex pipiens fatigans, em Florianópolis (Santa Catarina) por meio de capturas intra e extradomiciliárias realizadas concomitantemente. Rev. Bras. Malariol. D. Trop., 9: 77-78.

RAJENDRAN, R. \& REUBEN, R. (1991) Evaluation of the water fern Azolla microphylla for mosquito population management in the rice-land agro-ecosystem of south India. Med. Vet. Entomol. 5: 299-310.

RAMSAY, J.A. (1950). Osmotic regulation in mosquito larvae. J. Exp. Biol., 27: 141-157.

REINERT, J.F. (1975). Mosquito generic and subgeneric abbreviations (Diptera: Culicidae). Mosq. System, 7: 105-110.

REITER, P. (1983) A portable, battery-powered trap for collecting gravid Culex mosquitoes. Mosquito News 43: 496-499.

REMINGTON, C.L. (1945) The feeding habits of Uranotaenia lowi Theobald (Diptera: Culicidae). Ent. News, 56: 32-37; 64-68.

RISHIKESH, N.; BURGES, H.D. \& VANDEKAR, M. (1983). Operational use of Bacillus thuringiensis serotype $\mathrm{H}$. 14 and environmental safety. WHO/VBC/83.871, 9 pp.

RIVIERE, F.; KAY, B.H.; KLEIN, J.M. \& SECHAN, Y. (1987) Mesocyclops aspericornis (Copepoda) and Bacillus thuringiensis var. israelensis for the biological control of Aedes and Culex vectors (Diptera: Culicidae) breeding in crab holes, tree holes and artificial containers. J. Med. Entomol. 24: 425-430.

ROBERTS, D.R.; ALECRIM, W.D.; TAVARES, A.M. \& RADKE, M.G. (1987). The housefrequenting, host-seeking and resting behavior of Anopheles darlingi in Southeastern Amazonas, Brazil. J. Am. Mosq. Control Assoc., 3: 433-441.

ROBERTS, D.W.; DAOUST, R.A.; WRAIGHT, S.P. (1983). Bibliography on pathogens of medically important arthropods: 1981. WHO/VBC/83.1, 323 pp.

ROSA-FREITAS, M.G. (1989). Anopheles (Nyssorhynchus) deaneorum: a new species in the albitarsis complex (Diptera: Culicidae). Mem. Inst. Oswaldo Cruz, 84: 535-543.

ROSA-FREITAS, M.G.; BROOMFIELD, G.; PRIESTMAN, A.; MILLIGAN, P.J.M.; MOMEN, H. \& MOLYNEUX, D.H. (1992). Cuticular hydrocarbons, isoenzymes and behavior of three populations of Anopheles darlingi from Brazil. J. Am. Mosq. Control Assoc., 8: 357-366.

ROSA-FREITAS, M.G.; DEANE, L.M. \& MOMEM, H. (1990). A morphological, isoenzymatic and bihavioural study of ten populations of Anopheles albitarsis Lynch-Arribalzaga, 1878 (Diptera Culicidae) including from the type-locality - Baradero, Argentina. Mem. Inst. Oswaldo Cruz, 85: 275-289.

ROZEBOOM, L.E. \& KOMP, W.H.W. (1950) A review of the species of Culex of the subgenus Melanoconion (Diptera, Culicidae). Ann. Ent. Soc. Am., 43: 75-114.

ROZENDAAL, J.A. (1989) Impregnated mosquito nets and curtains for self-protection and vector control. Trop. Dis. Bull. 86: 1-41.

RUTLEDGE, L.C. WARD, R.A. \& GOULD, D.J. (1964). Studies on the feeding response of mosquitoes to nutritive solutions in a new membrane feeder. Mosquito News, 24: 407-419.

SALLUM, M.A.M. (1994) Revisão da Seção Spisseps de Culex (Melanoconion) (Diptera: Culicidae). Tese, São Paulo: Fac. Saúde Públ., Univ. S. Paulo. 
SAWYER, B.V. \& DAVIDSON, O. (1981). Transportation techniques for mosquito eggs. Trans. Roy. Soc. Trop. Med. Hyg., 74: 604-605.

SCHICK, R.X. (1970) The Terrens group of Aedes (Finlaya). Contrib. Amer. Ent. Inst., Mosquito Studies. 5: 1-158.

SCORZA, J.V. (1972) Observaciones bionomicas sobre Culex pipiens fatigans Wied., 1829 de Venezuela. Univ. de los Andes, Mérida, Venezuela. $198 \mathrm{pg}$.

SERUFO, S.C.; OCA, H.M.; TAVARES, V.A.; SOUZA, A.M.; ROSA, R.V.; JAMAL, M.C.; LEMOS, J.R.; OLIVEIRA, M.A.; NOGUEIRA, R.M. \& SCHATZMAYR, H.G. (1993). Isolation of dengue virus type 1 from larvae of Aedes albopictus in Campos Altos, state of Minas Gerais, Brazil. Mem. Inst. Oswaldo Cruz, 88: 503-504.

SHANNON, R. (1939). Methods for collecting and feeding mosquitos in jungle yellow fever studies. Amer. Journ. Trop. Med., 19: 131-140.

SHANNON, R.C. \& FROBISHER, Jr. M. (1931). A comparison of the effect of various substances upon larvae of Aedes aegypti. Amer. J. Hyg., l4: 426-432.

SHANNON, R.C.; WHITMAN, L. \& FRANCA, M. (1938) Yellow fever virus in jungle mosquitoes. Science, 88: 101-110.

SHARMA,V.P.; ANSARI, M.A. \& RAZDAN, R.K. (1993) Mosquito repellent action of Neem (Azadirachta indica) oil. J. Am. Mosq. Control Assoc. 9: 359-360.

SILVA, M.H.L.; MAGALHÃES, M.S.; SANCHES, E.G.; SANTOS, B.S.; LAMOUNIER, M.A.; CONSOLI, R.A.G.B. \& RABINOVITCH, L. (1991). Desenvolvimento de processo para a produção industrial de bioinseticida à base de Bacillus thuringiensis var israelensis. II Feira e Congresso Latino-Americano de Biotecnologia (FENABIO), Resumos, 6-12 de julho, 1991, São Paulo, SP.

SINGH, K.R.P. \& BROWN, A.W.A. (1957). Nutritional requirements of Aedes aegypti L. J. Insect. Physiol., l: 199-220.

SNOW, W.F. (1971). The spectral sensitivity of Aedes aegypti (L.) at oviposition. Bull. Ent. Res., 60: 683-696.

SIRIVANAKARN, S. (1982) A review of the systematics and a proposed scheme of internal classification of the New World subgenus Melanoconion of Culex (Diptera: Culicidae). Mosq. System, 14: 265-333.

SIRIVANAKARN, S. \& WHITE, G.B. (1978) Neotype designation of Culex quinquefasciatus Say (Diptera: Culicidae). Proc. Entomol. Soc. Wash., 80: 360-372.

SOMBOON, P.; MORAKOTE, N.; KOOTTATHEP, S. \& TRISANAROM, U. (1993). Detection of sporozoites of Plasmodium falciparum in mosquitoes by Elisa: false positivity associated with bovine and swine blood. Trans. R. Soc. Trop. Med. Hyg., 87: 322-324.

SOPER, F.L. \& WILSON, D.B. (1943) Anopheles gambiae in Brazil, 1930-1940. Rockefeller Foundation, New York, 261 pp.

STONE, W.S. \& REYNOLDS, F.H.K. (1939). Hibernation of anopheline eggs in the tropics. Science, 90: 371-372.

STRICHMAN, D. (1982). Stimuli affecting sellection of oviposition by Aedes vexans (Diptera: Culicidade): light. J. Med. Entomol., 19: 181-184.

SUAREZ, M.F.; QUIÑONES, M.L.; PALACIOS, J.D. \& CARRILLO, A. (1990). First record of DDT resistance in Anopheles darlingi. J. Am. Mosq. Control Assoc., 6: 72-74.

SUBBARAO, S.K.; ADAK, T.; VASANTHA, K.; JOSHI, H.; RAGHVENDRA, K.; COCHRANE, A.H.; NUSSENZWEIG, R.S. \& SHARMA, V.P. (1988) Susceptibility of Anopheles culicifacies series $\mathrm{A}$ and $\mathrm{B}$ to Plasmodium vivax and Plasmodium falciparum as determined by immunoradiometric assay. Trans. R. Soc. Trop. Med. Hyg., 82: 394-397. 
SUDIA, W.D. \& CHAMBERLAIN, R.W. (1962). Battery operated light trap, an improved model. Mosquito News, 22: 126-129.

SUKAMAR, K.; PERICH, M.J. \& BOOBAR, L.R. (1991). Botanical derivatives in mosquito control: a review. J. Am. Mosq. Control. Assoc., 7: 210-237.

TADEI, W.; SANTOS, J.M.M.; COSTA, W.L.S. \& SCARDENA, V.M. (1988). Biologia dos anofelinos amazônicos. XII. Ocorrência de espécies de Anopheles, dinâmica da transmissão e controle da malária na zona urbana de Ariquemes, Rondônia. Rev. Inst. Med. Trop., S. Paulo, 30: 221-251.

TANNER, G.D. (1969). Oviposition traps and population samplingfor the distribution of Aedes aegypti. Mosquito News, 29: 116-121.

TAYLOR, D.S.; RITCHIE, C.A. \& JOHNSON, E. (1992) The killifish Rivulus marmoratus: a potential biocontrol agent for Aedes taeniorhynchus and brackish water Culex. J. Am. Mosq. Control Assoc. 8: 80-83.

TEMPELIS, C.H. \& GALINDO, P. (1970) Feeding habits of five species of Deinocerites mosquitoes collected in Panama. J. Med. Entomol., 7: 175-179.

THIERY, I.; HAMON, S. GAVEN, B. \& DE BARJAC, H. (1992) Host range of Clostridium bifermentans serovar malaysia a mosquitocidal anaerobic bacterium. J. Am. Mosq. Control Assoc. 8: 272-277.

TIKASINGH, E.S. \& LAURENT, E. (1981). Use of ovitraps in monitoring Haemagogus equinus populations. Mosquito News, 4l: 677-679.

TRENZ, F. (1934). De l'influence des rayons solaires sur le cycle évolutif de Aedes mariae C. R. Soc. Biol., Paris, ll5: 1108-11lo.

TRUMAN, J.W. (1968). Acetone treatment for preservation of adult and larvae mosquitoes. Ann. Ent. Soc. Amer., $6 l$ (3): 779-780.

VALENCIA, J D. (1973) A revision of the subgenus Carrollia of Culex. Contrib. Amer. Ent. Inst. Mosquito Studies XXXI.9: 1-134.

VERHANE, J.P; LEEUWENBERG, A.D.E.M; PONNUDURAI, T.; MEUWISSEN, J.H.E.T. \& VAN DRUTEN, J.A.M. (1988). The biotin-streptavidin system in a two-site ELISA for the detection of plasmodial sporozoite antigen in mosquitoes. Parasite Immun., 10: 17-31.

WALLIS, R.C. (1954). The effect of population density and of $\mathrm{NaCl}$ concentrations in test series in laboratory experiments with ovipositing Aedes aegypti. Mosquito News, 14: 200-204.

WARD, R.A. (1984) Second supplement to "A catalog of the mosquitoes of the world" (Diptera: Culicidae). Mosq. System., 16: 227-270.

WEISER, J. (1982). Guide to field determination of major groups of pathogens affecting arthropod vectors of human diseases. WHO/VBC/82.860, $43 \mathrm{pp}$.

WESTERDAHL, B.B.; WASHINO, R.K. \& PLATZER, E.G. (1981). Successfull establishment and subsequent recycling of Romanomermis culicivorax (Mermithidae: Nemato$\mathrm{da}$ ) in a rice field following postparasite application. WHO/ $\mathrm{VBC} / 81.826,10 \mathrm{pp}$.

WHO (1962). A practical guide for malaria Entomologists in the African Region of WHO. WHO, Regional Office for Africa, Brazzaville.

WHO (1970). Resistance of vectors and reservoirs of disease to pesticides. Technical Repport Series, nr. 585, $88 \mathrm{pp}$.

WHO (198la). Informal consultation on the use of fish for mosquito control. TDR/BCV/ ICMC/81.3, 49 pp.

WHO (198lb). Data sheet on the biological control agent Dugesia dorotocephala (Woodworth, 1897) - California non canibalistic strain. WHO/VBC/81.800, ll pp. 
WHO (1984). Report of the seventh meeting of the scientific working group on biological control of vectors. TDR/BCV/SWG - 7/84.3, 33 pp.

WHO (1985). Informal consultation on the development of Bacillus sphaericus as a microbial larvicide. TDR/BVC/Sphaericus/85.3, 23 pp.

WHO (1986). Resistance of vectors and reservoirs of disease to pesticides. Technical Report Series, $737,87 \mathrm{pp}$.

WHO (1987a). Report of an informal consultation on the detection isolation, identification and ecology of Biocontrol agents of disease vectors. TDR/BCV/IC - GE/87.3, 41 pp.

WHO (1987b). Report of an informal consultation on the role of molecular biology and genetic engineering in the development of biocontrol of disease vectors. TDR/BCV/ $\mathrm{MB}$ - GE/87.3, 16 pp.

WHO (1990). Pesticide application equipment for vector control. Technical Report Series, 791, 58 pp.

WIGGLESWORTH, V.B. (1933). The adaptation of mosquito larvae to salt water. J. Exp. Biol., 10: 27-37.

WIRTZ, R.A.; BURKOT, T.R.; GRAVES, P.M. \& ANDRE, R.G. (1987). Field evaluation on enzyme-liked immunosorbent assays for Plasmodium falciparum and Plasmodium vivax sporozoites in mosquitoes (Diptera: Culicidae) from Papua New Guinea. J. Med. Entomol., 24: 433-437.

WRIGHT, J.W. (1971). The WHO programme for the evaluation and testing of new insecticides. Bull. Wld. Hlth. Org., 44: 11-22.

ZAHNER, V.; CAVADOS, C.F.G.; RABINOVITCH, L.; SANTOS, B.S.; LAMOUNIER, M.A. \& CONSOLI, R.A.G.B. (1990). Novas amostras de Bacillus cristalogênicos isolados de solos brasileiros. Anais do $2^{e}$ Simpósio de Controle biológico, Brasília, 14-18 de outubro de 1990.

ZAVALA, F.; GWANZ, R.W.; COLLINS, F.H.; NUSSENZWEIG, R.S. \& NUSSENZWEIG, $\mathrm{V}$. (1982) Monoclonal antibodies to circumsporozoite proteins identify the species of malaria parasites in infected mosquitoes. Nature, 299: 737-738.

ZAVORTINK, T.J. (1968) A prodrome of the genus Orthopodomyia. Contrib. Amer. Ent. Inst. Mosquito Studies VIII. 3: 1-221.

ZAVORTINK, T.J. (1972) The New World species formerly placed in Aedes (Finlaya). Contrib. Am. Ent. Inst. Mosquito Studies XXVIII, 8: 1-206.

ZAVORTINK, T.J. (1973) A review of the subgenus Kerteszia of Anopheles. Contrib. Amer. Ent. Inst., Mosquito Studies. 9: 1-59.

ZAVORTINK, T.J. (1979) The new sabethine genus Johnbelkinia and a preliminary reclassification of the composite genus Trichoprosopon. Contrib. Amer. Ent. Inst. Mosquito Studies XXXV. 17: 1-61.

ZAVORTINK, T.J.; ROBERTS, D.R. \& HOCH, A.L. (1983) Tricoprosopon digitatum Morphology, biology, and potential medical importance. Mosq. System., 15: 141-148.

ZHEN, T.M. \& KAY, B.H. (1993) Comparison of sampling efficacy of sweeping and dipping for Aedes aegypti larvae in tires. J. Am. Mosq. Control Assoc. 9: 316-320.

ZULUETA, J. (1950). Comparative oviposition experiments with caged mosquitoes. Amer. J. Hyg., 52: 133-142. 


\section{ÍNDICE REMISSIVO}

A

abdome, 27, 36

morfologia, 27

abrigo, 117

absorção, 40 - 41, 50

acasalamento, 42

ácido úrico, 42, 52

acrodendrofilia, 90, 154

acrodendrófilo, 128, 133, 151, 152

acúleo, 33,34

adulto

alimentação, 39

captura, 167

coleta, 161 - 164

criação, 185

manutenção de colônia, 185

montagem, 168, 170

morfologia interna, 39

nutrição, 39

teste susceptibilidade a inseticida, 179

tórax, 23

transporte, $167-169,175$

adultos

morfologia, 19

Aedeomyia, 25, 92, 94, 100

Aedeomyia squamipennis, 102

Aedeomyiini, 92, 94, 100

Aedes, 25, 41, 48, 92, 94, 101 - 102, 104, 115. 126,158

biologia, 122

desenvolvimento embrionário, 49

distribuição, 122

genitália masculina, 114

identificação, 104, 110

ovo, 31

subgênero, 104

Aedes aegypti, 45, 47, 49, 52 - 53, 105, 110,

$112,114-115,117-118,122,141,153,191-192$

abrigo, 116

alimentação, 39

antropofilia, 117

biologia, 116

cópula, 42, 116 - 117 criação, 191

criadouro, 116

densidade, 116

disseminação, 115

distribuição geográfica, 115

eclosão dos ovos, 192

endofilia, 117

fertilidade de ovos, 46

hematofagia, 116

no Brasil, 115 - 116

oviposição, 117

ovo, 141

relação com a febre amarela, 117

relação com o dengue, 117

visão, 47

Aedes aenigmaticus, 108

Aedes albifasciatus, 105, 112, 122

Aedes albopictus, 109, 113 - 114, 118 - 119,

153, $191-192$

biologia, 118

cópula, 42

criadouro, 118

dengue, 118

disseminação, 118

distribuição geográfica, 118

hematofagia, 118

oviposição, 118

ovo, 118

relação com a transmissão de arbovírus, 118

Aedes arborealis, 109, 114

Aedes argyrothorax, 109, 114

Aedes augustivittatus, 108

Aedes aureolineatus, 109

Aedes crinifer, 108, 112

Aedes fluviatilis, 49, 53, 109, 114, 119, 122, 190 criação, 191

desova, 43

Aedes fulvithorax, 109, 114

Aedes fulvus, 107, 110, 121

Aedes hastatus, 108, 110

Aedes hortator, 107, 114

Aedes jacobinae, 108

Aedes lepidus, 108, 114, 122 
Aedes natronius, 54

Aedes nubilus, 122

Aedes oligopistus, 108, 110

Aedes pennai, 105, 110

Aedes perventor, 107

Aedes thyachophilus, 108, 112

Aedes scapularis, 108, 112, 119 - 120, 122

biologia, 119

criadouro, 119

densidade, 120

distribuição geográfica, 119

filariose, 120

hematofagia, 120

relação com a transmissão de patógenos, 120

Rocio, 120

Aedes serratus, 108, 112, 122

Aedes stigmaticus, 107

Aedes taeniorhynchus, 107, 112, 121

arbovirose, 121

biologia, 121

criadouro, 121

densidade, 121

distribuição geográfica, 121

hematofagia, 121

relação com a transmissão de patógenos, 121

Aedes teaniorhynchus, 119

Aedes terrens, 109, 114

Aedini, 92, 94, 100, 102 - 104, 116 - 117, 120,

$122,138,145$

arbovirose, 104

criadouros, 102, 103

densidade, 102

eclosão dos ovos, 103

aerênquima, 55

algas, 55

alimentação, 55, 168

larva, 50

alimentação açucarada, 185, 187, 191 - 192, 194,196

alimentação com carboidratos adulto, $\mathbf{4 0}$

alimentaçāo das larvas, 191, 192

alimentação sanguínea, 185, 187, 191 adulto, 41

alula, 21, 25

Amazónia, 79, 81 - 83, 86 - 87, 103, 127, 132, 144

aminoácido(s), 41, 51

animais de sangue frio, 122, 150

Ankylorhynchus, 57

Anoedioporpa, 136, 138, 145

anofelino, 58, 79, 174 - 175, 177 - 178

adulto, 58

biologia, 92

diferença de, 58

distribuição, 92

IRMA, 176

larva, 58

ovo, 58 pupa, 59

Anofelinos

transmissão de doenças, 78

Anophele oswaldoi, 53

Anopheles, 25, 41, 44, 48, 54, 59 - 61, 70,

$78-79,158,183$

adulto, 59

diferença de, 59

espécies, 60

heterocromossomas sexuais, 48

larva, 59

ovo, 31

pupa, 59

subgêneros, 60

Anopheles albitarsis, 63, 74, 79, 83 - 85, 194,

196

biologia, 84

criadouro, 84

densidade, 84

distribuição geográfica, 83

relação com a malária, 84

zoofilia, 84

Anopheles anchietai, 69,77

Anopheles antunesi, 63, 75

Anopheles aquasalis, 65, 75, 79, 82, 196

abrigo, 83

biologia, 82

criadouro, 82 - 83

densidade, 82 - 83

distribuição geográfica, 82

filariose, 83

hematofagia, 83

relação com a malária, 83

zoofilia, 83

Anopheles argyritarsis argyritarsis, 63, 72

Anopheles argyritarsis sawyeri, 63, 72

Anopheles ballator relação com a malária, 91

Anopheles bambusicolus, 66, 72

Anopheles bellator, 66, 72, 79, 90 - 91

biologia, 90

distribuição geográfica, 90

hematofagia, 91

Anopheles benarrochi, 65, 75

Anopheles braziliensis, 63, 74, 79, 85

biologia, 85

criadouro, 85

distribuição geográfica, 85

exofilia, 85

relação com a malária, 85

zoofilia, 85

Anopheles bustamantei, 70

Anopheles crucians, 48

Anopheles cruzii, 67, 72, 79, 89 - 91

acrodendrofilia, 90

biologia, 89

bromélias, 89

criadouro, 89

densidade, 89 
distribuição geográfica, 89

exofilia, 89

hematofagia, 89

malária simiana, 90

relação com a malária, 90

Anopheles darlingi, 55, 61, 74, 79 - 83, 85 - 88

abrigo, 80

antropofilia, 80

biologia, 80

criadouro, 80

densidade, 81

distribuição geográfica, 80

endofilia, 80

exofagia, 80

filariose, 82

hematofagia, 81

infecção natural, 82

inseticida, 80

oviposição, 81

relação com a malária, 81

Anopheles deaneorum, 63, 74, 79, 84, 194 - 196

biologia, 85

criação, 194

criadouro, 85

densidade, 85

distribuição geográfica, 84

relação com a malária, 85

Anopheles dunhani, 64, 75

Anopheles eiseni, 67, 78

Anopheles evandroi, 70

Anopheles evansae, 66, 75, 79, 86, 88

Anopheles fluminensis, 69, 77

Anopheles galvaoi, 65, 75, 79, 88

Anopheles gambiae, 49, 61, 155

oviposição, 43

Anopheles gilesi, 67, 77

Anopheles homunculus, 67, 72, 79, 91

biologia, 91

distribuição geográfica, 91

relação com a malária, 91

Anopheles humunculus, 90

Anopheles ininii, 64, 75

Anopheles intermedius, 70, 77

Anopheles kompi, 68, 70

Anopheles laneanus, 66, 72

Anopheles lanei, 63, 74

Anopheles lutzi, 63, 75

Anopheles maculipes, 69, 77

Anopheles mattogrossensis, 67, 76 - 77

Anopheles mediopunctatus, 69, 77

Anopheles minor, 69, 78

Anopheles neivai, 66, 72, 92

Anopheles neomaculipalpus, 69, 76

Anopheles nigritarsis, 67

Anopheles nimbus, 68,70

Anopheles nuneztovari, 64, 75, 79, 85 - 86

biologia, 86

criadouro, 86

distribuição geográfica, 85 identificação, 86

relação com a malária, 86

zoofilia, 86

Anopheles oswaldoi, 64, 75, 79, 87 - 88

biologia, 87

criadouro, 87

distribuição geográfica, 87

exofilia, 88

relação com a malária, 88

zoofilia, 88

Anopheles parvus, 63, 75

Anopheles peryassui, 67, 78

Anopheles pseudotibiamaculatus, 67, 77

Anopheles punctimacula, 69, 77

Anopheles punctimaculata, 49, 70

Anopheles rachoui, 70

Anopheles rangeli, 64, 75

Anopheles rondoni, 66, 74

Anopheles shannoni, 69, 78

Anopheles squamifemur, 67

Anopheles strodei, 66, 74, 79, 88

Anopheles thomasi, 68,70

Anopheles tibiamaculatus, 67, 78

Anopheles triannulatus, 79, 86 - 87

biologia, 87

criadouro, 87

distribuição geográfica, 86

exofilia, 87

relação com a malária, 87

zoofilia, 87

Anopheles triannulatus davisi, 64, 75, 86

Anopheles triannulatus triannulatus, 64, 74, 86

Anophelinae, 45, 57 - 58, 92, 188

gêneros, 59

larva, 49

ovos, 29

trombeta, 36

Anophelini, 92

antena, 18, 21 - 22, 47

fêmea, 21

macho, 21

antepronoto, 21,23

anticorpo monoclonal, 175 - 178

marcação com iodo, 175

antropofilia, 61, 154, 191

ânus, 27, 40, 42, 51

aparelho bucal, 21, 23, 33

aparelho digestivo

adulto, 39

aparelho reprodutor feminino, 43,45

aparelho reprodutor masculino, 44

arbovirose, 103-104, 117, 122, 127 - 128, 131 - 133, 142 - 145, 149, 151, 154

área pos-espiracular, 21

área pré-escutelar, 21

armadilha, 163

automática, 163

CDC, 163 - 164 
de oviposição, $55,163,184$

de Shannon, 162

luminosa, 163 - 164

New Jersey, 163 - 164

asa, $21,25,46$

aspectos

morfologia, 29

aspersor ULV, 165

Astronotus ocellatus, 159

audição, 47

autogenia, 39

B

Bacillus, 188

Bacillus sphaericus, 157 - 158

Bacillus thuringiensis, 157 - 158

Bacillus thuringiensis israelensis, 157

bactéria, 157 - 158, 188

bambu, 56, 154

Belostoma micantulum, 159

berne, 127, 148

biologia, 39

Bironella, 59

bomba cibarial, 39 - 41, 47

bomba faringeana, 39 - 41

bomba salivar, 40

bromélia, 54, 56, 88, 90 - 91, 116, 145, $153-154,166$

bromélia-malária, 90

bursa copulatrix, 45

C

cabeça, 19

cálice micropilar, 31

cálice ovariolar, 174

calíptera, 21, 25

canal alimentar, 21, 39

canal salivar, 21

captura, 169

capturador, 161 - 162

carbamato, 155

carboidrato, 39 - 40, 48, 51, 185 - 186

Carrollia, 136, 145

cecos gástricos, 50 - 52

cefalotórax, 36

Cellia, 61

célula furcada anterior, 130

cercas, 25, 27, 29, 107, 123

cerdas, 27

acrosticais, 21

antealares, 21

dorso-centrais, 21

dorso-centrais anteriores, 21

mesepimerais inferiores, 27

mesepimerais superiores, 27

mesocatepisternais inferiores, 27

mesocatepisternais superiores, 27

pos-espiraculares, 27

pré-alares, 27 pré-espiraculares, 27

proepisternais, 27

supra-alares, 21,27

Chagasia, 57, 59 - 60

adulto, 59

biologia, 59

criadouro, 59

diferença de, 59

identificação, 59

larva, 59

pupa, 59

tufo palmado, 35

cibário, 40

ciclo gonotrófico, 173

CL50, 181 - 182

CL90, 181 - 182

claspete, 27,29

classificação, 57

clipeo, 21, 39 - 40

cloreto de sódio, 54

Coelomomyces, 158

colonia de mosquito, 184, 190, 192

água, 190

contaminação por microorganismo, 190

manejo, 190

manutenção, 183

concordância gonotrófica, 43,46

Conopostegus, 128 - 129, 133

biologia, 133

identificação, 130, 133

controle, 54

biológico, 55, 156 - 159, 183

físico, 156, 183

químico, 155, 183

cópula, 27, 42, 193

Ver acasalamento

cópula forçada, 193

copulas intraespecíficas, 42

Coquillettidia, 93 - 94, 98, 147 - 148

Coquillettidia chrysonotum, 148 - 149

Coquillettidia venezuelensis, 148 - 149

cório, 45

corpo gorduroso, 42, 52 - 53

corpo monoclonal, 78

coxa, 25, 27

coxa anterior, 21

criação de Culicídeo

considerações éticas, 183

medidas de segurança, 183

criadouros, 46, 54 - 55, 82, 88, 165 - 166, 169

artificiais, 56

classificaçōes, 56

naturais, 56

cromossoma, 48

cromossoma politênico, $48,50,81$

Culex, 25, 48, 92, 96, 100, 134 - 136, 138,

$145-146,158$

biologia, 134

genitália masculina, 138 
identificação, 134 - 135, 138

ovo, 31,135

Culex (Lutzia), 53

Culex amazonensis, 145

Culex coronator, 143

Culex declarator, 144

Culex fatigans, 139

Culex nigripalpus, 142 - 144 ornitofilia, 143

Culex pipiens, 48

Culex pipiens fatigans, 139

Culex pipiens pipiens, 45

Culex pipiens var. molestus oviposição, 43

Culex quinquefasciatus, 49, 53 - 54, 82 - 83 , $117,120,122,139-142$

antropofilia, 141

biologia, 139, 142

cópula, 42

criação, 190

criadouro, 139

distribuiçāo geográfica, 139

endofilia, 141

filariose, 142

hematofagia, 141

identificação, 139

larva, 139

ornitofilia, 141

ovo, 141,190

relação com a transmissão da filariose, 141

relação com a transmissão de arboviroses, 142

Culex saltanensis, 143 - 144

Culex usquatus, 143

Culex venezuelensis, 148

Culicidae, 57

Culicinae, 45, 57 - 58, 92, 153, 188

identificação, 93

segmentos abdominais, 36

tribos, 92

trombeta, 36

vista ventral, 36

culicineo, 58, 78, 194

adulto, 58

diferença de, 58

larva, 58

ovo, 58

pupa, 59

Culicini, 92, 96, 100, 134

biologia, 134

gêneros, 134

ovo, 134

Culicinomyces clavosporus, 158

Culicoides paraensis, 142

Culicospora magna, 158

cutícula, 19

Cyprinus carpio, 159
D

Davismyia, 151

DDT, 52, 80 - 81, 155 - 156

Deinocerites, 92, 96, 100, 134, 146

biologia, 146

identificação, 146

dengue, 103 - 104, 117, 119

densidade, 162

dentes do cibario, 39 - 40

Dermatobia hominis, 127, 148

desenvolvimento do foliculo ovariano, 45

desenvolvimento embrionario, 48 - 49

desenvolvimento larvário, 53, 188

fatores, 53

luz, 53

machos, 53

movimento da água, 54

poluentes organicos e inorgânicos, 54

relação com animais, 55

salinidade, 54

temperatura, 53

vegetação aquática, 55

vegetação não aquática, 54

vegetais, 146

desintoxicação

larva, 52

desova, 42 - 44, 169

em água, 187

em superficie solida, 187

diapausa, 48 - 49

ovariana, 46

dieta, 51

digestão, $41-42,50$

digestão sanguinea adulto, $\mathbf{4 1}$

Dirofilaria immitis, 121, 122

discordância gonotrófica, 43

dissecção, 168

de glándulas salivares, 78, 179

detecção de esporozoíto, 172

glandula salivar, 171 - 172

ovário, 171, 173

ovariolo, 173

sistema digestivo, 171 - 172

divertículo ventral, $39-40$

divertículos dorsais, 40

domicilio, 82 - 83, 88, 115 - 118, 120, 122

dorsomento, 31, 35

ducto

deferente, 44

ejaculador, 44

salivar, 39

Dugesia dorotocephala, 159

E

eclosão, 48 - 49

edeago, 27, 29

Eichornia, 55, 87, 146 
ELISA, 78, 88, 175, 178 - 179

anofelino positivo, 178

falso positivo, 179

preparação da placa para o teste, 178

processamento dos anofelinos, 178

processamento e teste dos mosquitos, 178

Elodea, 195

embrião, 48

empódio, 25

encefalite, 104, 121, 127, 142, 147

Equina Oeste, 104

Ilhéus, 152

Oeste, 142

Saint Louis, 104, 127, 142 - 143, 151 - 152

Venezuelana, 127, $142-143,148$

endocório, 31, 48

endofilia, 61

enxames, 42

enzimas, 41

digestivas, 41

epitélio folicular, 46

escapo, 20 - 21

escleritos, 19

escova oral, $31,33,50$

escudo, 21, 23, 27

escutelo, 21, 23, 27

es 8 fago, 39 - 40,50 - 51

esparmatozóides, 44

espécies cripticas, $81,83-84$

espermateca, 42 - 43, 45 - 46

espermátides, 44

espermatócitos, 44

espermatogonias, 44

espermatozoides, $42-43,46$

espiráculo, 21, 27, 33, 49

esporozoíto, $78,84-85,87,122,172-173,175$, 177

estenogamia

estenógamas, 42,183

estenogâmicas, 42,141

esternito, 19, 21, 27

estômago, 40 - 41, 50 - 51, 78, 157, 172, 175

eurigamia

eurigamas, 42, 183

eurigâmicas, 42,194

excreção, 40

adulto, 42

larva, 52

exocório, $29,31,48$

exoesqueleto, 19

exúvia pupal, 36,171

exúvia larval, 171

$\mathbf{F}$

falosoma, 27, 29

faringe, $40,50-51$

febre amarela, $103-104,117,119,121$, $131-134$ febre amarela silvestre, $117,119,131$ - 132 , 152, 154

febre amarela urbana, 104, 117, 119

fecundação, 29, 42, 195

fêmeas

longevidade, 39

fêmur, 25

fertilidade, 53

fertilização, 46,48

filariose, $82-83,141$ - 142

filtração, 50

flagelo, 21,47

Flavivirus, 117, 120

flutuadores, 29

folículo ovariano, 45

formas anômalas, 61

fotocinese, 54

fototeletaxia, 54

frutose, $41,168,185$

fungo, $157-158,185$

G

gaiola, 161, 168 - 169, 185 - 187, 190 - 191, 194

Gambusia affinis, 159

garimpos, 82

genitália externa, 27

genitália feminina, 27

Culicinae, 29

genitália masculina, 27, 29, 171

Anophelinae, 29

Culicinae, 29

rotação, 44

germário, 43, 45

Giovannolaia, 102

glândula acessória, 43 - 44

glândula salivar, $21,40,48,50$ - 51, 53, 78, 85, $87,91,173,175$

adulto, 39

glicogênio, 39, 52

glicose, 41, 168, 185

gonocoxito, 27, 29, 36, 195

gonostilo, 27, 29, 36, 195

Grabhamia, 124, 126 - 127

biologia, 126

identificação, 126

H

Haemagogus, 92, 94, $101-102,126,128$ - 130,

$132-133$

biologia, 128

criadouro, 128

desenvolvimento embrionário, 49

espécies, 128

identificação, 128, 130

Haemagogus albomaculatus, 130, 132 - 134

biologia, 132

distribuição geográfica, 132

relação com a transmissão de arbovirus, 132

Haemagogus baresi, 130 
Haemagogus capricornii, 130, 133

Haemagogus janthinomys, $130-134$

biologia, 131

criadouro, 131

distribuição geografica, 131

hematofagia, 131

ovo, 131

relação com a transmissão de arbovirus, 131

Haemagogus leucocelaenus, 129, 134

biologia, 134

distribuição geografica, 134

relação com a transmissão de arbovírus, 134

Haemagogus leucophoebus, 129, 134

Haemagogus spegazzinii, 129, 133

Haemagogus tropicalis, 129

halter, 21, 47

Hazardia milleri, 158

Helobdella triserialis lineata, 159

hematofagia

Ver repasto sanguineo

Hemiptera, 159

hemocele, 19, 52

hemolinfa, 19, 52

hipofaringe, 21, 23, 31, 40, 50

hormônios juvenis, 156

Howardina, 104

I

idade cronológica, 46

idade fisiologica, 46, 48, 173

identificação

adultos das espécies de Anopheles, 61

espécies de Aedes fêmeas, 105

espécies de Aedes larvas, 110

espécies de plasmódio, 174

espécies de Psorophora fèmeas, 123

fêmeas de Haemagogus, 129

gêneros de Anopheles, 59

genitália masculina de Culicinae, 101

larvas das espécies de Anopheles, 70

subgénero de Anopheles, 60

subgêneros de Culex, 135

tribos e gêneros de Culicinae, 93,98

Inéus, 127

imunensaio, 78 - 79, 84, 87, 174 - 175, 177, 179

indução à oviposição, 195

infecção malárica, 171

infecção natural, 88, 90, 119 - 120, 132 - 134, $143,147,152,154$

infecção plasmodial, 174

infecções

em mosquitos, 78

ingestão, $39-41,50,52,188$

inibidores da formação de quitina, 156

insetário, 184 - 185

considerações éticas, 183

controle de temperatura e umidade, 185

luminosidade, 185

medidas de segurança, 183 normas gerais, 184

inseticida, 80, 155 - 157, 159, 163 - 165, 168,

$179,181,184$

refratariedade, 156

resistência, 156, 179

resistência adquirida, 156

resistência comportamental, 156

resistência fisiológica, 156

inseticida químico, 156 - 157

inseticida residual, 164

interespecíficos

copula, 42

internódio de bambu, 128, 153, 166

intestino médio, 40, 50, 52, 157

IRMA, 78, 175, 178

anofelino positivo, 177

controle negativo, 177

controle positivo, 177

falso positivo, 179

preparação da placa para o teste, 176

isca

processamento e teste dos mosquitos, 176

animal, 162

humana, 162

luminosa, 162 - 163

J

Janthinosoma, 124, 127 - 128

biologia, 127

identificação, 127

Jh. longipes, 154

Johnbelkinia, 93, 98, 154

K

Kerteszia, 54, 60, 70, 78 - 79, 83, 88 - 92

biologia, 92

L

labela, 21 - 23, 40 - 41, 47

lábio, 21, 23, 31, 40, 50

lábio dobrado, 41

labro, 21, 23

Lagenidium giganteum, 158

larva, 54, 70, 158 - 159, 165 - 167, 171

abdome, 33

alimentação, 31

alimento, 188, 195

Anophelinae, 33, 35

aparelho bucal, 31

cabeça, 31,33

captura, 165

cerdas, 31

coleta, 165 - 166

criação, 184, 188 - 189, 195

Culicinae, 33 - 34

heliofila, 53

manutenção, 188, 195

medida quantitativa, 166

predadora, 52, 126, 146

predadores, 55 
respiração, 182

sobrevida, 55

teste de susceptibilidade a inseticida, 181

tórax, 33

transporte, 168 - 169

umbrofila, 53

larvária

eclosão, 188

larvas

biologia, 49

morfologia, 29

morfologia interna, 49

larvas predadoras

Toxorhynchites, 58

larvicida, 55, 156, 181 - 182

Leptognia sp, 158

Limatus, 93, 96, 150, 153

Li. durhami, 153

Li. flavisetosus, 153

lipides, 51

lobo anal, 31,33 - 34

lobo genital, 36

longevidade, 39

fatores extrínsecos, 48

fatores intrinsecos, 48

fêmeas, 48

macho, 48

Lophopodomyia, 60,70

Lutzia, 135, 146

Lynchiella, 57

M

Macaua, 151

Macropodus opercularis, 159

malária, $61,78,81,83,85,87$ - 91, 122, 165 de aves, 122,144

malária de bromélias, 90 - 91

malária simiana, 90,92

maltose, 41

manchas da asa, 25

mandíbula, 21, 23, 31, 50

Mansonia, 48 - 49, 55, 59, 93 - 94, 98, 147 - 149, 158

identificação, 147

larva, 49

ovo, 147

Mansonia titillans, 147 - 148

Mansoniini, 93 - 94, 146

biologia, 147

densidade, 147

gêneros, 147

larva, 147

ovo, 147

maxila, $2 i, 23,31,50$

Mayaro, 103 - 104, 127

mecanismo de regulação larva, 52

Melanoconion, 135 - 136, 138, 144 - 145

biologia, 145 seções, 144

Melao, 121

membrana peritrofica, $41,50,52$

Aedes, 41

Anopheles, 41

membrana vitelina, 48

Mermithidae, 158

mesanepimero, 21

mesocatepisterno, 21

mesómeron, 21

mesoposnoto, 21, 23, 27

mesotórax, 23

metabolismo, 39

metamorfose, 33

Metarhyzium anisopliae, 158

metatorax, 23, 36

Methopreme, 156

Microculex, 136, 138, 145

microorganismo, 55

micrópila, 29, 31

montagem, 171

adulto, 168

adultos, 170

alfinete entomológico, 170

em lâmina, 171

genitália masculina, 171

larva, 171

ovo, 171

morfologia externa, 19

morfologia interna, 39 - 40

N

necessidade nutricional

adulto, 41

larva, 51

nematódeo, 158

Nosema algerae, 158

Novyella, 102

nulipara, 173

nutrição, 41, 48, 50

larva, 50

Nyssorhynchus, 60, 70, 78 - 79, 84, 88, $194-196$

biologia, 79,88

criação, 194

criadouro, 79

O

occipicio, 21

Ocellatus, 144

Ochlerotatus, 104, 119, 121 - 122

biologia, 119

criadouro, 119

estonogamia, 119

eurigamia, 119

identificação, 119

olho, 19, 21, 31

olho composto, 36,47

omatideos, 19,47 
onipara, 173

oocisto, $78,88,175$

obcito, 45

Oomycete fungi, 158

Oreochromis spilurus spilurus, 159

organoclorados, 155

organofosforado, 155

orgão

Johnston, 47

Nuttall \& Shipley, 33

orgãos dos sentidos, 19 adulto, 47

Oropouche, 103 - 104, 142, 149

Orthopodomyia, 25, 33, 48 - 49, 93, 96, 100, 149

Orthopodomyia albicosta, 149

Orthopodomyia fascipes, 149

Orthopodomyiini, 93, 96, 100, 149

ovário, $43,45,174$ dissecção, 173

ovário nuliparo, 174

ovário oníparo, 174

ovariolo, 43, 45 - 46, 174 dissecção, 173

oviduto, 46,174

oviduto comum, 45 - 46

oviduto interno, 43

oviduto lateral, 43,45

oviposição, 29, 43, 46 - 48, 55, 157, 163, 169 , 187

comportamento, 46

fatores biologicos, 46

fatores físicos, 46

fatores quimicos, 46

indução, 187

ovo, $29,31,39,41$ - 42,45 - 46, 48, 104, 119 ,

$122-123,126,128,171,187,191$

Aedes, 31

Anopheles, 31

aspecto, 48

Culex, 31

eclosão, 31, 128

manutenção, 187

transporte, 169

ovos flutuadores, 29

ovulação, 46

ovulo, 46

$\mathbf{P}$

paleta, 36

palpo maxilar, $21-22,25$

paludismo, 83, 87 - 88

papilas anais, $33-34,52-53$

papilas retais, 40

parâmeros, 27

paraproctos, 27

parasita, 55, 78

parenquimas aeriferos, 146

patógeno, 121, 126 - 127, 131, 147, 154, 157, 195

peças bucais, 50 pecten, 33,35

pecten sifonal, 34

pedicelo, 20 - 21

pediculo ovariolar, 43

peixe, 159

pente do segmento VIII, 34

perfil de isoenzimas, 81

peridomicílio, $80,82,115,118,120,127$, $153-154$

periplasma, 48

peritroide, 164

pernas, 25, 36

Peytonulus, 151

Phenacomyia, 136, 146

Phoniomyia, 93, 98, 153

piráculos, 23

piretroide, 155

Pistia, 55, 87, 146 - 147, 195

placa espiracular, 33,35

placa tergal, 33, 35

plantas aquáticas, 55

plasmódio, 78, 81, 85, 88, 91, 122, 175, 177, 179

plasmodio de ave, 102

Plasmodium beghei, 41

Plasmodium brasilianum, 90

Plasmodium cathemerium, 144

Plasmodium falciparum, 79, 82, 84 - 85, 87 - 88

Plasmodium gallinaceum, 41, 122

Plasmodium juxtanucleare, 144

Plasmodium malariae, 82, 88

Plasmodium simium, 90

Plasmodium vivax, 79, 82, 84 - 88

pleura, 19, 27

Poecilia reticulata, 159

poluentes, 54

pool feeding, 41

predadores, 157,159

proboscide, $21-22,40,47$

produtos de origem vegetal, 157

produtos químicos derivados de plantas, 55

pronoto, 23

proteina, $41,52,78$

proteina CS, 78, 85, 87, 175, 177, 179

Protomacleaya, 104

protórax, 23

protozoário, 157 - 158

proventriculo, 51

Psorophora, 25, 53, 92, 94, 100, 102, 122 - 123, 126- 127

biologia, 122, 126

desenvolvimento embrionário, 49

identificaçãa, 122, 126

ovo, 122

subgèneros, 123

Psorophora albigenu, 124 - 125

Psorophora albipes, 125, 128

Psorophora amazônica, 125

Psorophora ciliata, 124, 126 
Psorophora cilipes, 123, 126

Psorophora cingulata, 125, 127

Psorophora circunflava, 125

Psorophora confinnis, $126-127$

Psorophora dimidiata, 125

Psorophora discrucians, 124

Psorophora ferox, 125, $127-128$

biologia, 127

densidade, 127

distribuição geográfica, 127

relação com a transmissão de patógenos, 127

Psorophora forceps, 125

Psorophora holmbergii, 124

Psorophora lanei, 124

Psorophora lutzi, 125, 128

Psorophora pseudomelanota, 124

Psorophora saeva, 123

Psorophora varinervis, 126

pupa, 70, 189

abdome, 36

aspecto, 36

cefalotorax, 36

cerdas, 36

criação, 184

manutenção, 189

medida quantitativa, 189

transporte, 169

pupa de macho, 36

$\mathbf{Q}$

quetotaxia, 31, 34 - 35

quimiorreceptores, 47

quitina, 53, 156

quitinização, 53

$\mathbf{R}$

radioimunensaio, 175, 177

radioimunometria

Ver IRMA

reabsorção de água, 40, 42, 52

relíquia ovariolar, 173

remigio, 25

repasto sanguíneo, $39,41-44,46,169$,

191 - 192

volume, 41

repelentes, 157

reprodução, 42, 157

reserva nutricional

iarva, 52

respiração, 54 - 55

larva, 49

Rhynchotaenia, 148

Rocio, 103 - 104, 120, 127

Romanomermis culinivorax, 158

Ru. frontosa, 154

Ru. magna, 154

Runchomyia, 93, 98, 154
$\mathbf{S}$

Sabethes, 53, 93, 98, $150-151,153$

biologia, 151

identificação, 150

subgênero, 151

Sabethes belizarioi, 151

Sabethes chloropterus, 151 - 152

biologia, 152

distribuição geográfica, 152

identificação, 151

relação com a transmissão de arbovirose, 152

Sabethes intermedius, 151

Sabethes quasicyaneus, 151

Sabethes soperi, 151

Sabethini, 92 - 94, 98, 150, 152 - 154

biologia, 150

identificação, 101, 150

larva, 101

Sabethinus, 151

Sabethoides, 151

sacarose, 41, 168, 185

salinidade, $54,121,187$

saliva, $40-41$

Salvinia, 146 - 147

sanguinea, 42

secreção, 40, 50

segmento $X, 33$ - 34

sela, 33

sela do lobo anal, 35

Shannoniana, 93, 98, 154

sifão, $33-34,49,53,110,139$

Indice, 33

simulideos, 158

sistema digestivo

adulto, 40

larva, 50 - 51

solução açucarada, 169

solução sulfocrômica, 190

Spisseps, 135, 145

Stegomyia, 104, 114

biologia, 115

identificação, 115

oviposição, 115

Stethomyia, 60, 70

subfamília Culicinae, 92

espécie, 92

gênero, 92

tribos, 92

subfamílias, 57

substâncias açucaradas, 41

sucção, 41

T

tarsômeros, 25

tecido nervoso, 53

técnica, $78-79,161$

técnica de cópula forçada, 183, 194

técnica de disseç̧ão

Ver dissecção 
técnica de montagem

Ver montagem

técnica de transporte, 167

técrica imunológica, $173-174$

tergito, 19, 21, 27

tergito IX, 29

tergito $\mathrm{XI}, 27$

teste, 177

susceptibilidade, 179

teste imunenzimático, 175

testículo, 44

tíbia, 25

tigmotropismo, 54

Tinolestes, 138, 145

Tolypocladium cylindrosporum, 158

tórax, 23

cerdas, 27

escamas, 27

toro, $20-21,47$

Toxorhynchites, 53, $57-58,159$

alimentação, 39

Toxorhynchitinae, 57,92

referências, 58

Toxorhynchitini, 92

Tr. digitatum, 154

transmissão de patógenos, 58

transmissão transovariana, 104, 117, 158

transmissores de paludismo, 79

transotransmissoras, 119

transovariana, 132

transporte

larva, 169

mosquito morto, 167

mosquito vivo, 168

ovo, 169

pupa, 169

traquéias, 23,45

traqueias ovarianas, 46

traquéola ovariana, 173

tribo Aedeomyiini, 102

tribo Aedini

biologia, 102

Trichoprosopon, 53, 93, 98, 154

triglicérides, 39

trocanter, 21, 25

trofocitos, 43,45

trombeta, 36

tubo mortifero, 167

tubos de Malpighi, 40, 48, 50 - 53

Tucunduba, 151 tufo palmado, 35

tufos postero-laterais de escamas, 25, 27

Turbellaria, 159

Typha, 146

U

Uranotaenia, 25, 48, 93, 100, 149 - 150

Uranotaeniini, 149

Uranotaenini, 93, 100

Utricularia, 55

V

vagina, 43,45

vaso deferente, 44

vaso eferente, 44

Vavraia culicis, 158

vegetais, 55

veia anal, 21

veia costa, 21

veia cúbito, 21

veia média, 21

veia média $1+2,21$

veia média 2,21

veia radial, 25

veia rádio, 21

veia sub-costa, 21

veias da asa

anal, 25

costa, 25

cubital, 25

medianas, 25

radiais, 25

subcosta, 25

verde-paris, 155

vértex, 21

vértice, 21

vesículas seminais, 44

vetor, $79,81,84-85,102,117,119-120,128$, $132-133,141,152,156-157,183$

virus, 157

visão, 47

vitaminas, 42

vitelário, 45

vitelo, $43,45,48$

W

W. bancrofti, 82 - 83, 120, 141

Wyeomyia, 93, 98, 152 - 153

$\mathbf{Z}$

Zigomicetos, 158 


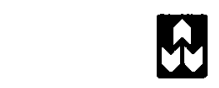

Impresso em

AO LIVRO TECNICO

IND. E COM. LTDA

Rua Sá Freire, 40 - Săo Cristóváo - CEP 20930-430

els. (021) 580-6230/580-1168 - FAX (021) 580-9055 e 580-4597

e-mail: aolivtec@ism.com.br
Rio de Janerro - RJ - Brasil 
biológicos. Encontram-se também descritas técnicas de coleta, transporte, manutenção, montagem e dissecção de mosquitos para determinação da idade fisiológica ou identificação de esporozoítas de Plasmodium. Também são explicadas as instalações básicas de um insetário para a colonização de mosquitos, os cuidados e medidas de segurança recomendáveis, as técnicas especificas para a criação de espécies dos gêneros Aedes e Culex, assim como o método de inseminação artificial, aplicável na reprodução de Anopheles eurigâmicos. Segue-se ainda uma extensa relação de referências bibliográficas sobre todos os temas abordados.

Há quase trinta anos não se publicava no Brasil uma obra que tratasse de todos esses assuntos em conjunto. Desta forma, o presente manual, confeccionado para suprir essa deficiência, facilitará o trabalho de todos aqueles que se interessam pelo estudo dos mosquitos em nosso pais. 
Informações concisas e atualizadas, abrangência nos assuntos abordados, texto claro e didático - são estas as marcas deste Principais Mosquitos de Importância Sanitária no Brasil.

Há quase trinta anos não se publicava no Brasil obra que tratasse do tema de forma tão consistente. Assim, Principais Mosquitos de Importância Sanitária no Brasil, confeccionado para suprir essa deficiência bibliográfica, com certeza facilitará o trabalho de todos aqueles que se interessam pelo estudo dos mosquitos em nosso país. 